\title{
REGULATION OF METABOLIC ENZYMES DURING HIBERNATION IN GROUND SQUIRRELS
}

\author{
Khalil Abnous \\ Pharm. D., Mashad University of Medical Sciences, 1998
}

A Thesis Submitted to the Faculty of Graduate Studies and Research in partial fulfillment of the requirements for the degree of

\section{Doctor of Philosophy}

Department of Chemistry

Ottawa-Carleton Institute of Chemistry

Carleton University

Ottawa, Ontario, Canada

C copyright 2007

Khalil Abnous 


$\begin{array}{ll}\begin{array}{l}\text { Library and } \\ \text { Archives Canada }\end{array} & \begin{array}{l}\text { Bibliothèque et } \\ \text { Archives Canada }\end{array} \\ \begin{array}{l}\text { Published Heritage } \\ \text { Branch }\end{array} & \begin{array}{l}\text { Direction du } \\ \text { Patrimoine de l'édition }\end{array} \\ \begin{array}{l}\text { 395 Wellington Street } \\ \text { Ottawa ON K1A ON4 }\end{array} & \begin{array}{l}\text { 395, rue Wellington } \\ \text { Ottawa ON K1A ON4 } \\ \text { Canada }\end{array}\end{array}$

Your file Votre référence ISBN: 978-0-494-33480-5 Our file Notre référence ISBN: 978-0-494-33480-5

NOTICE:

The author has granted a nonexclusive license allowing Library and Archives Canada to reproduce, publish, archive, preserve, conserve, communicate to the public by telecommunication or on the Internet, loan, distribute and sell theses worldwide, for commercial or noncommercial purposes, in microform, paper, electronic and/or any other formats.

The author retains copyright ownership and moral rights in this thesis. Neither the thesis nor substantial extracts from it may be printed or otherwise reproduced without the author's permission.
AVIS:

L'auteur a accordé une licence non exclusive permettant à la Bibliothèque et Archives Canada de reproduire, publier, archiver, sauvegarder, conserver, transmettre au public par télécommunication ou par l'Internet, prêter, distribuer et vendre des thèses partout dans le monde, à des fins commerciales ou autres, sur support microforme, papier, électronique et/ou autres formats.

L'auteur conserve la propriété du droit d'auteur et des droits moraux qui protège cette thèse. $\mathrm{Ni}$ la thèse ni des extraits substantiels de celle-ci ne doivent être imprimés ou autrement reproduits sans son autorisation.
In compliance with the Canadian

Privacy Act some supporting forms may have been removed from this thesis.

While these forms may be included in the document page count, their removal does not represent any loss of content from the thesis.
Conformément à la loi canadienne sur la protection de la vie privée, quelques formulaires secondaires ont été enlevés de cette thèse.

Bien que ces formulaires aient inclus dans la pagination, il n'y aura aucun contenu manquant.

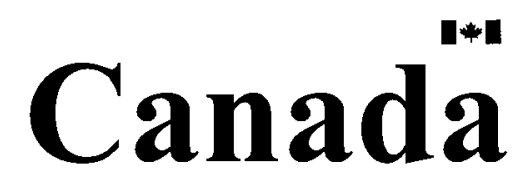




\begin{abstract}
Hibernation is a winter survival strategy for many small mammals. Animals sink into deep torpor, body temperature falls to near $0^{\circ} \mathrm{C}$ and physiological functions are strongly suppressed. Enzymes are the catalysts of cells and their appropriate control is critical to hibernation success. This thesis explores the properties and regulation of key enzymes of carbohydrate metabolism (hexokinase, HK), energy metabolism (creatine kinase, CK; AMP deaminase, AMPD) and signal transduction (Akt; MAPKAP-K2), highlighting skeletal muscle ground squirrels (Spermophilus richardsonii). The studies showed that changes in $\mathrm{pH}$, temperature, inhibitor and activator concentrations, mRNA transcript and protein levels, and binding to myofibrils are involved in regulating these enzymes during hibernation. Moreover, reversible protein phosphorylation proved to be a key regulatory mechanism, reducing the activity of all these enzymes during hibernation. Analysis of total protein content by Western blotting found decreased HKII, CK and P-Akt protein during hibernation but no change in Akt and MAPKAP-K2 content. Analysis of temperature effects on enzymes, via Arrhenius plots, showed that CK, AMPD and MAPKAP-K2 had significantly higher activation energies in hibernating animals Urea denaturation and pulse proteolysis showed that HKII from hibernators had greater resistance to chemical denaturation than the euthermic enzyme but studies on CK and MAPKAP-K2 found no stability differences. Affinity of CK and AMPD for their substrates decreased during hibernation. HK, Akt and MAPKAP-K2 showed reduced ATP affinity in hibernation but HK affinity for glucose remained stable, and Akt and MAPKAP-K2 showed higher affinity for their substrate peptides. Protein kinases (PKA,
\end{abstract}


PKC, PKG) increased AMPD activity from both euthermic and hibernating animals but decreased CK activity; AMPK elevated HK activity in euthermic muscle. Protein phosphatases generally reversed these actions. Changes in enzyme phosphorylation state during hibernation were confirmed by elution profiles of the enzymes off DEAE Sephadex, patterns that were interconverted after incubations that stimulated protein kinases and phosphatases. Overall, these studies showed that multiple mechanisms of enzyme regulation, particularly protein phosphorylation, contribute to reorganizing enzymatic function and stability during hibernation. 


\section{Acknowledgements}

I would like to thank Professor Ken Storey for his supervision during my PhD. studies. I will always remember how energetic he answers the scientific questions and guides students. His deep knowledge, hard work and interest in research are the main reasons for his success. I am really very proud of being his student. He really is the best supervisor. I appreciate Jan Storey for her critical editing and comments and being patient with writing.

I would like to specially thank my lovely wife, Dr Shokoufeh Lavaei, for her continuous support, encouragement and patience during my study. Amir Hossein's birth was the best thing that happened in our life. I also thank our parents for their support.

Special thanks to Chris Ramnanan and Dave McMullen for the ir help during the first days of my study in the Storey lab. Thanks also to Pier, Mamady, Chris, Jiayun, Jacques Judeh and Ryan for valuable scientific discussions. I also thank all of the Storey lab members for the scientific and fun environment that we have in the lab.

Finally, I thank the Ministry of Health and Medical Educ ation of Iran for their financial support that allowed me to undertake Ph.D. studies. 


\section{Table of Contents}

\section{Page}

Title Page

i

Acceptance Sheet ii

Abstract

Acknowledgements $\quad$ V

Table of Contents

List of Abbreviations vii

List of Figures $\quad$ X

List of Tables xiii

Chapter 1 General Introduction 1

$\begin{array}{lll}\text { Chapter } 2 \text { Skeletal muscle hexokinase: regulation in a hibernating } & 18\end{array}$ ground squirrel

Chapter $3 \quad$ Regulation of skeletal muscle creatine kinase in a 49 hibernating mammal

Chapter 4 AMP deaminase regulation in ground squirrels during $\quad 90$ hibernation

$\begin{array}{lll}\text { Chapter } 5 & \text { Regulation of Akt during hibernation in Richardson's } & 114\end{array}$ ground squirrels.

Chapter $6 \quad$ Regulation of MAPKAP-K2 in Richardson's ground 136 squirrels during Hibernation.

$\begin{array}{lll}\text { Chapter } 7 \quad \text { General Discussion } & 154\end{array}$

$\begin{array}{ll}\text { Publication List } & 172\end{array}$

$\begin{array}{lc}\text { References } & 174\end{array}$ 


\section{List of abbreviations}

$\beta-G P$

$\beta-\mathrm{MeSH}$

3'-UTR

ADP

AEC

AMP

AMPD

AMPK

ANS

AP

ARE

ATF

ATP

$\mathrm{Bad}$

BAT

cDNA

CHOP

CK

COX2

$\mathrm{Cr}$

CREB

CS

DEAE

DTT

$\mathrm{Ea}$

EDTA

EGTA

$\mathrm{F} 2,6 \mathrm{P}_{2}$

G6P $\beta$-glycerophosphate

$\beta$-mercaptoethanol

3'-Untranslated region

Adenosine diphosphate

Adenylate energy charge

Adenosine monophosphate

AMP deaminase

AMP dependent protein kinase

8-anilino-1-naphthalene-sulfonic acid

Alkaline phosphatase

Adenylate/uridylate-rich element

Activating transcription factor

Adenosine triphosphate

$\mathrm{Bcl}-2$-associated death protein

Brown adipose tissue

Complementary deoxyribonucleic acid

CCAAT/enhance-binding protein (C/EBP) homologous protein

Creatine kinase

Cyclooxygenase 2

Creatine

cAMP response element binding protein

Citrate synthase

Diethylaminoethyl

Dithiothreitol

Activation energy

Ethylenediamine-tetraacetic acid

Ethylene glycol-bis(2-aminoethylether)-N,N,N',N'-tetraacetic acid

Fructose-2,6-bisphosphate

Glucose-6-phosphate 


\begin{tabular}{ll} 
G6PDH & Glucose-6-phosphate dehydrogenase \\
GLUT4 & Glucose transporter 4 \\
GnHCl & Guanidine hydrochloride \\
GS & Glycogen synthase \\
GSK3 & Glycogen synthase kinase 3 \\
HK & Hexokinase \\
HM & Hydrophobic motif \\
Hsp25/27 & Heat shock protein 25/27 \\
IGF & Insulin-like growth factor \\
IL-6 & Interleukin 6 \\
IMP & 5'-Inosine monophosphate \\
IPA & Insoluble Protein A \\
Ka & Activation constant \\
LDH & Lactate dehydrogenase \\
MAPK & Mitogen activated protein kinase \\
MAPKAP-K2 & Mitogen activated protein kinase-activated protein kinase-2 \\
MEF & Myocyte enhancer factor \\
MR & Metabolic rate \\
NADH & B-Nicotinamide adenine dinucleotide, reduced form \\
NADPH & B-Nicotinamide adenine dinucleotide phosphate, reduced form \\
NES & Nuclear export signal \\
PAGE & Polyacrylamide gel electrophoresis \\
PCr & Phosphocreatine \\
PDH & Pyruvate dehydrogenase \\
PDK4 & PDH kinase isoenzyme 4 \\
PFK & 6-Phosphofructo-1-kinase \\
PH & Pleckstrin homology \\
PHLPP & PH domain leucine-rich repeat protein phosphatase \\
PI3K & Phosphoinositide-3 kinase \\
PIP3 & Phosphoinositide-3-phosphate \\
PK & Pyrute kinase \\
\hline
\end{tabular}




$\begin{array}{ll}\text { PKA } & \text { Protein kinase A } \\ \text { PKB } & \text { Protein kinase B/Akt } \\ \text { PKC } & \text { Protein kinase C } \\ \text { PKG } & \text { Protein kinase G } \\ \text { PKI } & \text { PKA inhibitor peptide } \\ \text { PMSF } & \text { Phenylmethylsulfonyl fluoride } \\ \text { PP } & \text { Protein phosphatase } \\ \text { PPt } & \text { Total protein phosphatases } \\ \text { PVDF } & \text { Polyvinylidene difluoride membrane } \\ \text { Q10 } & \text { Ratio of the rate of a reaction at one temperature } \\ \text { RGS } & \text { divided by the rate at a temperature 10 }{ }^{\circ} \text { less } \\ \text { RT-PCR } & \text { Richardson's ground squirrel } \\ \text { SDS } & \text { Reverse transcription polymerase chain reaction } \\ \text { SOX } & \text { Sodium dodecyl sulfate } \\ \text { Ta } & \text { 8-Hydroxy-5-(N,N-dimethylsulfonamido)-2-methylquinoline } \\ \text { Tb } & \text { Tumor necrosis factor- } \alpha \\ \text { TBST } & \text { Ambient temperature } \\ \text { TLGS } & \text { Body temperature } \\ \text { TNF } \alpha & \text { Tris-buffered saline containing the detergent Triton-X } \\ \text { TTP } & \text { 13-Lined ground squirrel } \\ & \end{array}$




\section{List of Figures}

Figure

Page

1-1 Body temperature as a function of time over a year starting in June for a golden-mantled ground squirrel

1-2 Relationship of the metabolic enzymes that are studied in the present thesis

2-1 Effect of $\mathrm{pH}$ on the activity of skeletal muscle HK

from euthermic ground squirrels.

2-2 Activity versus substrate concentration relationships for ground squirrel muscle $\mathrm{HK}$ showing data for free $\mathrm{HK}$ in crude extracts from euthermic and hibernating animals.

2-3 Distribution of HK between cytoplasmic and bound states in skeletal muscle extracts of euthermic and hibernating Richardson's ground squirrels.

2-4 Arrhenius plots for HK from skeletal muscle of euthermic and hibernating ground squirrels

2-5 Inhibition of ground squirrel muscle HK by G6P

2-6 Effect of in vitro incubations of ground squirrel muscle extracts under conditions that promote the action of protein phosphatases or protein kinases on the activity of $\mathrm{HK}$

2-7 Column chromatography of ground squirrel skeletal muscle HK

2-8 Selective thermal inactivation of HKII after incubation at $45^{\circ} \mathrm{C}$ for $60 \mathrm{~min}$

2-9 Stability of HK II from crude extracts of euthermic or hibernating muscle as a function of urea concentration Activity versus substrate conct
ground squirrel muscle $\mathrm{CK}$.

3-2 Arrhenius plots for skeletal muscle CK.

3-3 $\quad \mathrm{S}_{0.5}$ values for skeletal muscle CK at different temperatures. 
3-4 Effect of in vitro incubations promoting the action of

protein phosphatases or protein kinases on CK activity in soluble extracts of ground squirrel skeletal muscle.

3-5 Effect of in vitro incubations promoting the action of protein phosphatases or protein kinases on myosin-bound CK activity from ground squirrel muscle.

3-6 DEAE Sephadex ion exchange chromatography of ground squirrel skeletal muscle CK.

3-7 Relative CK protein content, CK mRNA transcript levels and CK maximal activity in skeletal muscle of ground squirrels

3-8 SDS-PAGE gel (10\% acrylamide) showing purification of CK from skeletal muscle of euthermic ground squirrels.

3-9 Analysis of the temperature and chemical stability of purified commercial rabbit muscle $\mathrm{CK}$

3-10 Analysis of the chemical stability of muscle CK from ground squirrels.

4-1 Effect of $\mathrm{pH}$ on the activity of skeletal muscle AMPD from euthermic and hibernating 13-lined ground squirrels

Activity versus AMP substrate concentration relationships for muscle AMPD from euthermic and hibernating 13-lined ground squirrels

4-3 Arrhenius plots for AMPD from skeletal muscle of euthermic and hibernating Richardson's ground squirrels

4-4 $\quad \mathrm{S}_{0.5}$ values for skeletal muscle AMPD at different assay temperatures.

4-5 Effect of in vitro incubations of muscle extracts from Richardson's ground squirrels under conditions that promoted the action of protein phosphatases or protein kinases on AMPD

4-6 DEAE Sephadex ion exchange chromatography of skeletal muscle AMPD from Richardson's ground squirrels.

5-1 Activity versus substrate concentration relationships for ground squirrel muscle Akt 
5-2 Activity versus fluorescent peptide substrate concentration for

Akt from liver of euthermic versus hibernating ground squirrels

5-3 Effect of temperature on Akt from skeletal muscle of euthermic and hibernating ground squirrels shown as Arrhenius plots

5-4 Effect of hibernation on total and phosphorylated levels of Akt in muscle and liver of Richardson's ground squirrels.

5-5 Akt activity in liver and skeletal muscle squirrel of euthermic and hibernating ground squirrels and the effect of alkaline phosphatase (AP) treatment on muscle Akt activity.

5-6 DEAE Sephadex ion exchange chromatography of ground squirrel skeletal muscle Akt.

6-1 Activity versus substrate concentration relationships for muscle MAPKAP-K2 from euthermic and hibernating ground squirrels

6-2 MAPKAP-K2 protein content, maximal activity at $22^{\circ} \mathrm{C}$ and $10^{\circ} \mathrm{C}$ and the effect of alkaline phosphatase treatment

6-3 Arrhenius plots for MAPKAP-K2 from skeletal muscle of euthermic and hibernating ground squirrels.

6-4 Analysis of the chemical stability of muscle MAPKAP-K2 from ground squirrels.

7-1 Relation between CK and AMPD.

7-2 MAPK signalling pathways 


\section{List of Tables.}

Table

Page

2-1 $\quad \mathrm{K}_{\mathrm{m}}$ values for substrates of skeletal muscle HK from euthermic versus hibernating Richardson's ground squirrels

3-1 $\quad \mathrm{S}_{0.5}$ values for substrates of skeletal muscle CK from euthermic and hibernating ground squirrels

3-2 Purification of CK from skeletal muscle of euthermic ground squirrels

4-1 $\quad \mathrm{S}_{0.5}$ values for skeletal muscle AMPD from euthermic versus hibernating ground squirrels.

4-2 Activators and inhibitors of Richardson's ground squirrel muscle AMPD.

5-1 $\quad \mathrm{S}_{0.5}$ values for substrates of skeletal muscle and liver Akt from euthermic and hibernating Richardson's ground squirrels.

6-1 $\quad \mathrm{S}_{0.5}$ values for substrates of skeletal muscle MAPKAP-K2 from euthermic versus hibernating Richardson's ground squirrels 


\title{
Chapter 1
}

\author{
GENERAL
}

INTRODUCTION 


\section{Hibernation}

Hibernation is the response used by some mammals to survive the adverse environmental conditions of winter, in particular cold ambient temperatures and limited food availability. The metabolic energy required to maintain a constant high (euthermic) body temperature $(\mathrm{Tb})$ in a cold environment becomes too great and so instead, animals conserve energy by entering deep torpor and allowing $\mathrm{Tb}$ to fall to near ambient. To endure, hibernators undergo complex beha vioural, morphological, physiological and biochemical changes (Carey et al, 2003). During torpor, body temperature falls to between $2-10^{\circ} \mathrm{C}$ in most temperature zones (Carey et al., 2003), heart beat is reduced from its normal 200-300 to just 3-5 beats/min (Zatzman 1984), respiration falls from 100-200 to 4-6 breaths/min (McArthur and Milsom, 1991) and all other physiological functions are similarly slowed (Wang et al., 1996). Metabolic rate is typically reduced to only $1-5 \%$ of the corresponding rate in euthermia (Geiser, 2004). Hibernators maintain a viable energy status despite the very low $\mathrm{Tb}$ values that for most nonhibernating mammals would cause lethal hypothermia. However, all of the noted changes in physiological parameters are restored rapidly to near-normal levels during periodic arousals (Carey et al, 2003).

Hibernation is a highly regulated state. Specific controls are applied to accomplish a wide range of actions including (a) a strong suppression of overall metabolic rate, (b) differential organ responses, (c) differential suppression of individual cellular processes to reorganize cell priorities for energy use, (d) differential gene/protein expression to put in place proteins/enzymes that aid hibernation, and (e) differential regulation of enzymes to resculpt metabolic functions and aid survival at near $0^{\circ} \mathrm{C}$ body temperatures (Storey, 
2003). In this thesis, my focus is on the mechanisms involved in the regulation of metabolic enzymes during hibernation to gain information on the overall control of energy metabolism in hibernation and on enzyme regulation at the low Tb values of the torpid state.

\section{Hibernation cycle}

Endothermic animals must produce substantial amounts of endogenous heat to sustain a constant $\mathrm{Tb}$ and even greater amounts to compensate for high heat loss during cold weather. This is especially important for small mammals, because of the ir high surface area to volume ratio. Production of high amounts of endogenous heat requires a higher metabolic rate and a higher intake of the food during the cold season. In this situation the cost of thermoregulation may become prohibitively expensive and, instead, many species abandon homeothermy and allow their metabolic rate and $\mathrm{Tb}$ to fall to low levels. There are two forms of torpor: daily torpor and hibernation. Daily heterotherms, which are species that enter torpor on a daily basis, appear to rely mostly on the fall in $\mathrm{Tb}$ during a few hours per day for metabolic reduction and energy savings. In contrast, hibernators that are capable of prolonged torpor bouts rely extensively on metabolic inhibition, in addition to $\mathrm{Tb}$ effects, to reduce metabolic rate to a fraction of that observed in daily heterotherms. In small hibernators, metabolic inhibition and the large fall in $\mathrm{Tb}$ are employed to maximize energy conservation, whereas in larger hibernators, metabolic inhibition appears to be employed to facilitate metabolic rate and $\mathrm{Tb}$ reduction at torpor onset (Geiser, 2004).

During the summer and early autumn before entering hibernation, animals such as 
ground squirrels (the model animal used in the thesis) store large amounts of body fat by eating extra food (hyperphagia). They also choose sheltered hibernacula such as underground burrows, caves or mines to protect them against potential predators and against the lowest environmental temperatures. Hibernacula typically show temperatures a few degrees above $0^{\circ} \mathrm{C}$ even when outside air temperature minima are below freezing (Geiser, 1988). The hibernating season consists of prolonged torpor bouts that are interspersed with short periods of arousal when animals rewarm themselves to $37-38^{\circ} \mathrm{C}$ and maintain euthermia for several hours. Figure 1-1 shows the profile of $\mathrm{Tb}$ in a goldenmantled ground squirrel over the course of one year, starting in June. Based on this figure, the hibernation season could be divided four stages: entrance, torpor (early and late), arousing, and interbout aroused (Epperson and Martin, 2002). Typically, there is a progressive increase in the length of torpor bouts during the autumn and early winter with maximum lengths in midwinter followed by shortening again in the spring The maximum length of torpor bouts can range in duration from a few days to up to 5 weeks and this varies from species to species and also with ambient temperature during hibernation (Carey et al., 2003).

Entry into hibernation is caused by an active suppression of metabolic rate coupled with a lowering of the hypothalamic set point, which reduces thermogenesis and leads to a gradual decline in Tb (Fig. 1-1) (Storey 1997). Early in the hibernation season, the animal goes through a series of "test-drops" while sleeping during which its $\mathrm{Tb}$ drops a few degrees and then returns to normal. Gradually, the animal cools to lower temperatures (typically within a degree or less of the ambient temperature) and torpor bouts become longer. During torpor, all physiological functions are suppressed to low 
Figure 1-1. Body temperature as a function of time over a year starting in June for a golden-mantled ground squirrel. The inset shows the pattern of three torpor-arousal cycles highlighting multiple stages: the entrance into torpor (EN) which lasts up to 12 hours, the early torpor (ET) within 48 hours of entering torpor, the late torpor (LT), arousal (AR) with a duration of $\sim 2$ hours, and finally interbout arousal (IBA) with a duration of $\sim 20$ hours (Carey et al., 2003). 
Figure 1-1

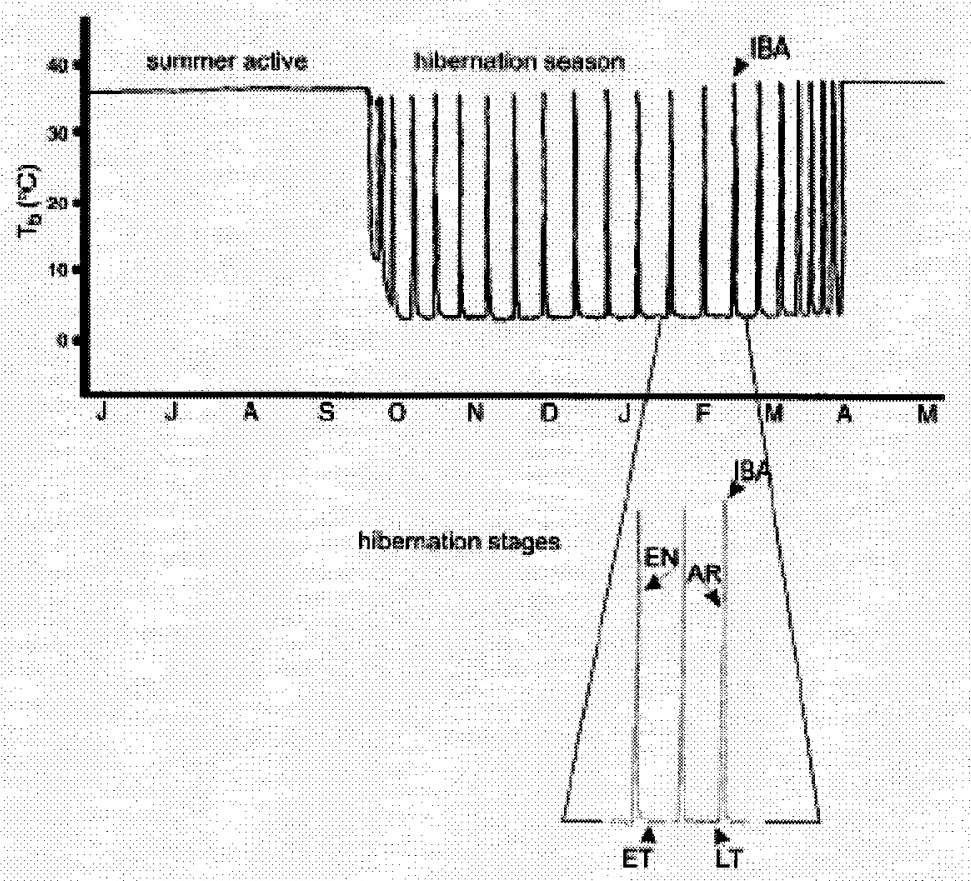


levels. For example, in hibernating ground squirrels metabolic rate often falls to only $1 \%$ of metabolic rate during euthermia, heart rate drops to only 5-10 beats per minute (Storey, 2003), and respiration is reduced to 4-6 breaths/min with some species even showing long apnoic periods (McArthur and Milsom, 1991). Renal function is greatly reduced or ceases altogether (Zatzman, 1984; Carey et al, 2003). After a period of deep torpor, animals arouse and return to euthermic $\mathrm{Tb}$ for a few hours. Arousal is initially and primarily fueled by non-shivering thermogenesis in brown adipose tissue (BAT) but after $\mathrm{Tb}$ rises above about $15^{\circ} \mathrm{C}$ skeletal muscle shivering also contributes to rewarming. The whole process is quite drastic as it involves raising $\mathrm{Tb}$ by more than $30^{\circ} \mathrm{C}$, increasing heart beat to the euthermic rate of $350-400$ beats per minute, and increasing the breaths taken per minute to more than 100 breaths per minute (Zatzman, 1984; McArthur and Milsom, 1991). All of these feats are accomplished within minutes to hours without harming the animal. Multiple reasons have been postulated for these periodic arousals from torpor including a need to eliminate metabolic wastes, to readjust neural circuits, or for species that eat during arousal to stock up on fuel reserves (Heller and Ruby, 2004).

\section{Metabolic control}

The reduction of metabolic rate during torpor is very important for survival in hibernators. The mechanisms of metabolic rate reduction are not fully known yet but there are several theories that attempt to explain the process. The early idea was that the fall in body temperature during entry into torpor caused the fall in metabolic rate (MR). This received support because the $\mathrm{Q}_{10}$ (ratio of the rate of a reaction at one temperature divided by the rate at a temperature $10^{\circ} \mathrm{C}$ less) for metabolic rate of hibernators is often 
approximately 2 which is typical of the effects of temperature on biochemical reactions. However, subsequent studies showed that many hibernating species with small body masses had $Q_{10}$ values of 3-4 for metabolic rate in euthermic versus hibernating states so that it was proposed that specific physiological inhibition, in addition to temperature effects, must be involved in the reduction of metabolic rate (Geiser, 2004). The alternate hypothesis, then, is that $\mathrm{Tb}$ may have no influence on torpor metabolic rate. It is argued that MR is down-regulated at torpor entry and the fall of $\mathrm{Tb}$ is the consequence of and not the reason for, the reduction of metabolic rate (Geiser, 2004). The third hypothesis is that metabolic rate during torpor is a function of the difference between body temperature and ambient temperature (ie. Tb-Ta) (Geiser, 2004).

Storey (1997) argued that metabolic rate is regulated to address multiple goals during hibernation. The primary goal of regulation is the coordinated suppression of cellular functions to a new, lower steady state while still maintaining a balance between the net rates of ATP-producing and ATP-utilizing reactions. The second goal is to address the specific needs of the hypometabolic state for different situations. For example, in hibernating mammals, regulation is applied to shift metabolism to an increased emphasis on lipid oxidation as the primary fuel for ATP production Multiple mechanisms may be involved in metabolic control during hibernation including covalent modification of proteins via reversible protein phosphorylation, differential gene expression, changes in enzyme/protein binding associations with subcellular structures, specific allosteric regulation of key enzymes, and variation in cellular $\mathrm{pH}, \mathrm{pCO}_{2}$, and temperature (Storey, 1997).

A number of metabolic enzymes have been shown to be regulated by reversible 
protein phosphorylation during hibernation. For example, studies of the regulation of carbohydrate metabolism in liver of the jumping mouse, Zapus hudsonius, showed that the properties of glycogen phosphorylase, 6-phosphofructo-1-kinase (PFK), pyruvate kinase and pyruvate dehydrogenase (PDH), key enzymes of glycogenolysis, were all altered during hibernation in a manner that would reduce their activity in vivo and that was consistent with the effects of protein phosphorylation on the enzymes (Storey, 1997). For example, the percentage of active PDH dropped from $15 \%$ in heart and $29 \%$ in kidney of euthermic jumping mice to just $1 \%$ in animals that had been hibernating $5-8$ days (Storey, 1997). MacDonald and Storey (2001) also reported that PFK showed altered kinetics during hibernation in Spermophilus lateralis (a hibernating ground squirrel); the $\mathrm{K}_{\mathrm{a}}$ values for $\mathrm{AMP}, \mathrm{ADP}, \mathrm{NH}_{4}{ }^{+}$and $\mathrm{F} 2,6 \mathrm{P}_{2}$ were $3-11$ fold higher at $5^{\circ} \mathrm{C}$ than at $37^{\circ} \mathrm{C}$. Inhibition by ATP and urea also became more potent at low temperature and inorganic phosphate became an inhibitor at $5^{\circ} \mathrm{C}$. By contrast, no major changes in glycolytic enzyme activities were observed during daily torpor in Djungarian hamsters (Phodopus sungorus) except for inactivation of the PDH complex in liver, brown adipose tissue, and heart. Indeed, PDH inactivation closely correlated with the reduction in total metabolic rate (Heldmaier et al., 1999).

More recent work has shown that reversible phosphorylation control during hibernation also extends to a variety of other metabolic processes. For example, phosphorylation of $\mathrm{Na}^{+} \mathrm{K}^{+} \mathrm{ATPase}$ reduced the activity of this ion pump by about $60 \%$ in muscle of hibernating ground squirrels (MacDonald and Storey, 1999). Activity of the ribosomal protein translation apparatus is also suppressed in hibernation by phosphorylation of key initiation and elongation factors (Frerichs et al., 1998; Chen et al., 2001). 


\section{Model animals}

Richardson'sground squirrels (Spermophilus richardsonii) and 13-lined ground squirrels (Spermophilus tridecemlineatus) are the two hibernating species that are studied in this thesis. Richardson's ground squirrels (also known as gophers, prairie gophers, yellow gophers, picketpins, flickertails, or tawny American marmots) eat leaves, flowers, seeds, and insects. They are ground-dwelling, burrowing mammals of 0.1-0.4 kg in mass that are active only during daylight hours. They dig meandering burrows of about 3.5 inches in diameter, 15-20 feet in length, and 4-5 feet below the surface. Richardson's ground squirrels hibernate alone in a special chamber called a hibernaculum. This chamber is initially constructed as an excavation off the main burrow system, but its connection is plugged with soil when the animal enters hibernation. The hibernaculum is a closed system consisting of a hibernaculum chamber, a drain tunnel to carry away moisture, and an exit tunnel that reaches almost to the surface. Hibernation for this species typically begins in September and lasts through to January, February, or March, depending on location. The range of the species includes portions of Alberta, Saskatchewan, Manitoba, Montana, North Dakota, South Dakota, and Minnesota.

Thirteen-lined ground squirrels are small prairie mammals with body length of $\sim 24 \mathrm{~cm}$. Adults weigh 130-180 g in summer but they gain considerable weight (laying down up to $4 \mathrm{~g}$ of fat per day) in late summer to raise their body mass to $220-240 \mathrm{~g}$ prior to hibernation. According to Cleary and Craven (1994), the range of thirteen-lined ground squirrels extends from Central Alberta, Manitoba, and Saskatchewan in the North to Texas and New Mexico in the South, and from Central Ohio in the east to Colorado in the west. They feed primarily on seeds and insects, including grasshoppers and cutworms. 
The species is an obligate hibernator and squirrels remain in their underground burrows continuously throughout the winter, entering hibernation in September or early October and emerging between late March and early May in the Northern parts of their range.

In this thesis my focus is on regulation of metabolic enzymes in skeletal muscle and liver of Richardson's and 13-lined ground squirrels during hibernation.

\section{Skeletal muscle}

During the hibernating season muscles mainly face two major problems. The first is a long period of inactivity during torpor and the second problem is fuel and energy limitation. In nonhibernating species, a prolonged period of skeletal muscle inactivity would result in severe atrophy - a serious loss of muscle mass and enzymatic activity. However, it has been shown that hibernators experience much less muscle atrophy during torpor than should be expected from about eight months of inactivity(Wickler et al., 1991). Moreover mass-specific activities of citrate synthase (CS) were increased in hibernating ground squirrels. Although not contributing to the strength of the muscle, increases in CS may help in preserving the other function of skeletal muscle, namely heat production (Wickler et al., 1991) since shivering thermogenesis contributes to the rewarming of the animal during arousal from torpor. Certain physiological changes have been identified that might help the skeletal muscle of hibernators to cope with the long sedentary months of winter. For example, capillarity is increased in skeletal muscle to maximize blood delivery and an increase in myoglobin content has also been reported (Postnikova et al., 1999).

Arousal requires intense thermogenesis to rewarm the body. This comes first from 
nonshivering thermogenesis in brown adipose tis sue but once the body is about half rewarmed, shivering thermogenesis by skeletal muscle is initiated and the two mechanisms rapidly restore euthermic $\mathrm{Tb}$ to $37^{\circ} \mathrm{C}$ (Wang et al., 1996). Shivering thermogenesis results from ATP hydrolysis by myosin ATPase in skeletal muscle and is powered by high rates of ATP turnover. To support this, selected hibernation-responsive changes in gene expression have been found. For example, myosin light chain $1 \mathrm{v}$ is upregulated in muscle (Fahlman et al., 2000). Fatty acid binding protein gene expression is also upregulated and this is an indicator that skeletal muscle relies on enhanced lipid catabolism in hibernation (Hittel and Storey, 2001). PDH kinase isoenzyme 4 (PDK4) expression was also increased under hibernating conditions. PDK4 inhibits PDH and thus minimizes carbohydrate oxidation by preventing the flow of glycolytic products into the tricarboxylic acid cycle (Buck et al., 2002).

\section{Liver}

The liver has a very important role in a number of processes that are likely to be crucial for survival of hibernation. Ground squirrels store fuel in the form of triacylglycerols in the adipose tissue and rely largely on this stored fat for survival of the winter. The processes of lipid metabolism include the lipolytic enzymes and proteins involved in transport of fatty acids, many of which are synthesized in the liver. The liver is also the site of synthesis for a number of enzymes involved in gluconeogenesis and ketone body formation, both processes required for fuel generation during the hibernation season. High glucose levels in the plasma are important for the arousal process. Glycogen stores in liver and muscle of the Arctic ground squirrel are replenished during interbout arousal 
(Galster and Morrison, 1975). Epperson et al. (2004) reported that three key enzymes of gluconeogenesis were up-regulated in the entrance period: pyruvate carboxylase, phosphoenolpyruvate carboxykinase 2 , and malate dehydrogenase. They also found that fatty acid binding protein increases during the winter. Moreover, the long-chainpreferring acyl CoA dehydrogenase and carboxylesterase 2 showed higher levels in liver during hibernation.

\section{Hypothesis}

Differential regulation of metabolic and signal transduction enzymes, particularly using the mechanism of reversible protein phosphorylation, adjusts enzyme properties to integrate and optimize their function between euthermic and hibernating states and between high and low $\mathrm{Tb}$ values.

\section{Objectives}

Hibernation is a highly regulated physiological state involving not just a strong suppression of overall metabolic rate but a controlled reorganization of metabolism to support long term viability at a low body temperature. Enzymes are the catalysts of cells and the appropriate control of enzymes of carbohydrate metabolism, energy metabolism, and signal transduction is key to hibernation success. The studies presented in this thesis analyze the kinetics parameters of key enzymes in euthermic and hibernating ground squirrels. Multiple regulatory mechanisms are evaluated such as changes in $\mathrm{pH}$, temperature, inhibitor and activator concentrations, total protein and mRNA transcript 
levels, and binding to myofibrils. A particular emphasis is placed on reversible protein phosphorylation as a central mechanism of enzymatic control in hibernation The properties and regulation of key enzymes of carbohydrate metabolism (hexokinase), energy metabolism (creatine kinase), and adenylate metabolism (AMP deaminase), and signal transduction (Akt, MAPKAP-K2) are addressed in the following chapters. Their relationships are summarized in Figure 1-2.

\section{Hibernator Enzymes}

The hexokinase family (HK; EC 2.7.1.1) catalyses the phosphorylation of glucose by ATP which is the first step in metabolism of the sugar. The product, glucose-6phosphate (G6P) can then be used by a variety of pathways including glycolysis to generate ATP, the pentose phosphate pathway to produce NADPH and other sugar phosphates, and the synthesis of glycogen to store carbohydrate fuel for future use (Wilson, 2003). There are four isozymes of HK in mammals (HK I-IV) that differ in their subcellular and tissue distribution (González et al., 1964; Katzen and Schimke, 1965), their affinity for substrates (ATP, glucose) and their inhibition by phosphate and G6P (Wilson, 2003). HKII is the primary hexokinase in ground squirrel skeletal muscle and studies of its kinetics and regulation are presented in Chapter 2. 
Figure 1-2. Relation of the metabolic enzymes that has been studied in present thesis. 


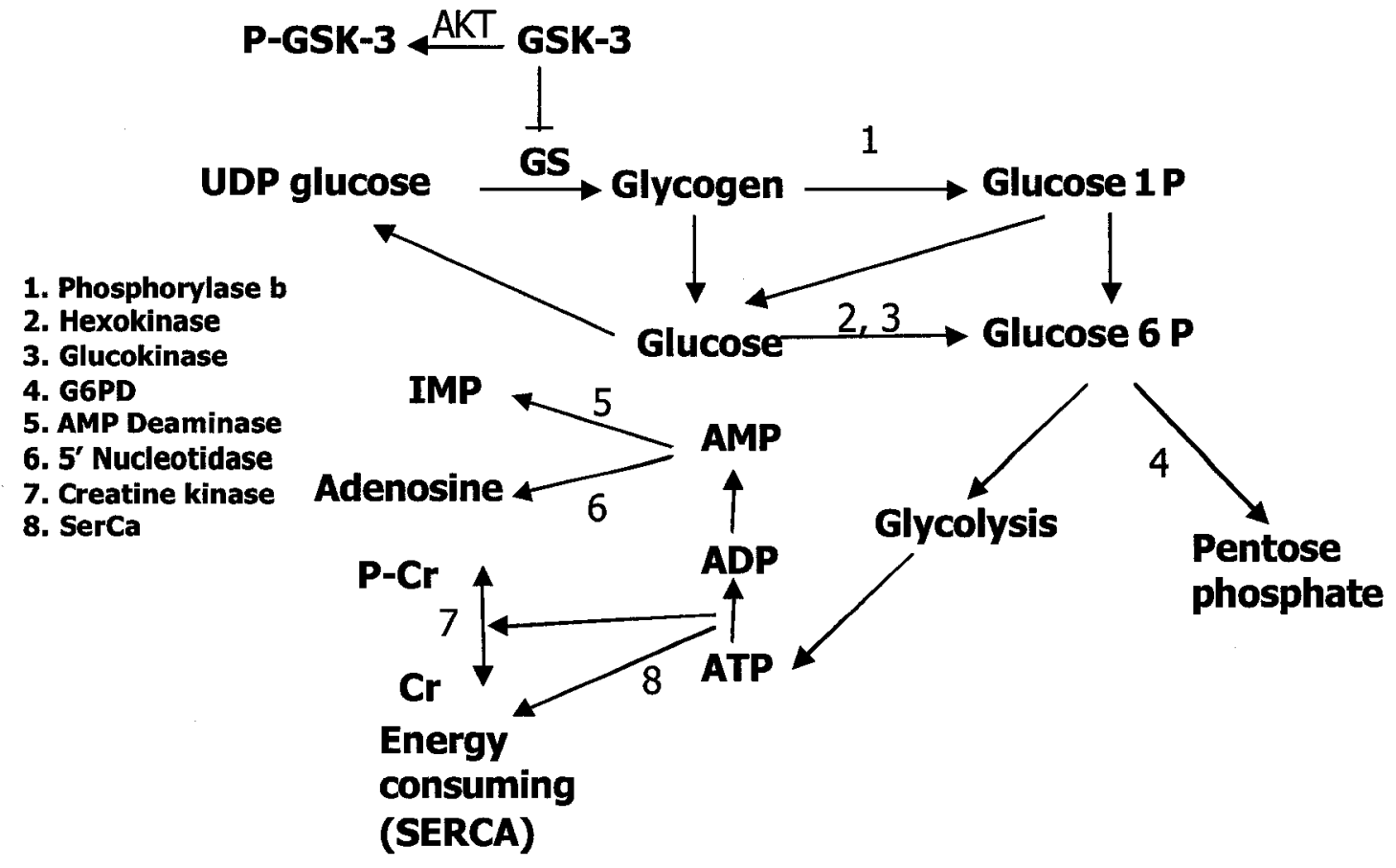


Creatine kinase (CK; EC 2.7.3.2) is a member of the phosphagen (guanidino) kinase family of enzymes. It catalyzes the transfer of a phosphate group from ATP to creatine $(\mathrm{Cr})$ to produce phosphocreatine $(\mathrm{PCr})$ and vice versa. The enzyme constitutes about $20 \%$ of the total soluble protein of skeletal muscle cells (Lipskaya, 2001). CK has two crucial roles: (a) as a reservoir of high energy phosphate to buffer fluctuations in the intracellular ATP/ADP ratio, and (b) in the $\mathrm{Cr} / \mathrm{PCr}$ shuttle to move high energy phosphate reserves between sites of ATP synthesis (mitochondria) and sites of high ATP consumption (e.g. the myosin ATPase in skeletal muscle) (McLeish\& Kenyon 2005). CK exists in three tissue-specific cytoplasmic forms: an MM-CK homodimer in skeletal muscle, a BB-CK homodimer in brain, and a MB-CK heterodimer in heart. In addition, two mitochondrial isozymes exist as octamers: the ubiquitous $\mathrm{Miu}$-CK and the sarcomeric Mis-CK (McLeish\& Kenyon 2005). Changes in the activity and regulation of CK can have important effects on the availability of ATP, the energy currency of the cell. The kinetics and regulation of hibernator skeletal muscle CK are presented in Chapter 3. AMP-deaminase (AMPD; EC 3.5.4.6) catalyzes the irreversible deamination of 5'-adenosine monophosphate (AMP) to 5'-inosine monophosphate (IMP). This enzyme plays an important role in keeping the adenylate energy charge high, especially in situations where ATP hydrolysis exceeds the rate of ATP synthesis, such as during intense muscle contraction During torpor in hibernator muscle, the total adenylate pool drops but adenylate energy charge, $\mathrm{AEC}=[\mathrm{ATP}+0.5 \mathrm{ADP}] /[\mathrm{ATP}+\mathrm{ADP}+\mathrm{AMP}]$, is maintained at a high level (MacDonald and Storey, 1999; English and Storey, 2000). The action of AMPD in draining AMP out of the adenylate pool is key to maintaining the 
high energy charge during torpor. Removal of AMP from the pool also pulls the adenylate kinase reaction ( $2 \mathrm{ADP} \rightarrow \mathrm{AMP}+\mathrm{ATP})$ to the right, to decrease the ADP concentration and maximize ATP. Coordination of AMPD and adenylate kinase maintains a high ATP/ADP ratio and adenylate energy charge in the cell (Lowenstein, 1990; Rundel et al., 1992). Analysis of hibernator skeletal muscle AMPD is presented in Chapter 4.

Akt (EC 2.7.11.1) is a member of the AGC (protein kinases A, G, and C) superfamily (Whiteman et al., 2002). Stimulation of a membrane receptor (such as by insulin) activates phosphoinositide-3 kinase (PI3K) which generates phosphoinositide-3phosphate (PIP3) that recruits inactive cytoplasmic Akt to the plasma membrane. Following membrane binding, Akt is activated by phosphorylation at two sites: Thr308 within the $\mathrm{T}$ loop of the catalytic domain (catalyzed by phosphoinositide dependent kinase 1) and at Ser473 in a noncatalytic region(Alessi et al., 1997). Phosphorylated Akt mediates a variety of metabolic actions, such as the anabolic and growth-promoting effects of insulin and insulin-like growth factor, activating the insulin-sensitive glucose transporter (GLUT4), increasing glucose uptake (Hill et al., 1999), promoting glycogen synthesis, facilitating lipogenesis from glucose, and regulating multiple proteins that control ribosomal translation (Whiteman et al., 2002). Moreover, Akt inhibits apoptosis (also called programmed cell death) by control of the pro-apoptotic protein BAD and regulates forkhead box, class O (FOXO) transcription factor. Previous studies have documented changes in the total and phosphorylated contents of Akt in selected tissues of hibernating species (Lee et al., 2002; Eddy and Storey, 2003; Cai et al., 2004). However, nothing is known about the enzymatic properties (e.g. kinetic, regulatory, thermal, 
stability properties) of Akt in a hibernating species. Chapter 5 analyzes the properties of this important signal transduction kinase in ground squirrel muscle.

Another protein kinase that is important in the control of cellular metabolism is the mitogen activated protein kinase-activated protein kinase-2 (MAPKAP-K2; EC 2.7.11.1). This is one of the several kinases that are downstream of the p38 MAPK (Hitti et al., 2006). In resting cells, MAPKAP-K2 is present in the nucleus but when activated, p38 phosphorylates key regulatory sites on MAPKAP-K2. The two enzymes then form a complex in the nucleus that can phosphorylate a variety of transcription factors to increase the transcription of numerous genes. Phosphorylation also unmasks the nuclear export signal (NES) in the G-terminal part of MAPKAP-K2 which is a prerequisite for nucleo-cytoplasmic transport of MAPKAP-K2. Once in the cytoplasm, MAPKAP-K2 can phosphorylate proteins such as glycogen synthase, Hsp25/27, tyrosine hydroxylase, 5-lipoxygenase and leukocyte-specific protein 1 (Kotlyarov and Gaestel, 2002; Kotlyarov et al, 2002). Hence, with both nuclear actions in gene expression and cytoplasmic actions in enzymatic control, MAPKAP-K2 may have an important role to play in hibernation. Again, as for Akt, nothing is known about the enzymatic properties of this important protein kinase in a hibernating species that must control its metabolism at both high and low body temperatures. Enzymatic studies of ground squirrel MAPKAP-K2 are presented in Chapter 6. 


\section{Chapter 2}

\section{SKELETAL MUSCLE HEXOKINASE: REGULATION IN A HIBERNATING GROUND SQUIRREL}




\section{Introduction}

Glucose is a key source of energy for living organisms. The first step in its metabolism is phosphorylation by the enzyme hexokinase (HK) to form glucose-6phosphate (G6P) which can then enter a variety of pathways. These include glycolysis to generate ATP, the pentose phosphate pathway to produce NADPH and sugar phosphates, and the synthesis of glycogen to store fuel for future use (Wilson, 2003). HK catalyzes the reaction: glucose $+\mathrm{ATP} \rightarrow \mathrm{G6P}+\mathrm{ADP}$. In mammals, there are four isozymes (HK IIV) that differ in subcellular and tissue distribution (Gonzalezet al., 1964; Katzen and Schimke, 1965). HKIV is also known as glucokinase; it is liver-specific with a high $\mathrm{K}_{\mathrm{m}}$ for glucose and designed for a primary function in glycogen synthesis. The other three isozymes have molecular weights of $\sim 100 \mathrm{kD}$ and low $\mathrm{K}_{\mathrm{m}}$ glucose values; they can be separated by ion exchange chromatography and isoelectric focusing (Gonzalezet al. 1964; Katzen and Schimke, 1965). Differential transcriptional regulation of HK isozymes may permit their selective expression in particular tissues, with distinct responses to altered metabolic status and probably differential involvement in various metabolic applications (Wilson, 1997). The isozymes differ in their affinity for substrates (ATP, glucose) and in their inhibition by phosphate and G6P (Wilson, 2003). Some HK isozymes bind to the outer membrane of mitochondria. Binding is critically dependent on a hydrophobic N-terminal sequence (Polakis and Wilson, 1985) that selectively targets HK to the porin that is located in contact sites on the mitochondria.

Studies in our lab have examined various aspects of regulatory control in hibernators including hibernation-responsive gene expression (Storey, 2003), differential control of cellular enzymes/proteins by reversible protein phosphorylation (MacDonald 
and Storey, 1998, 1999; Storey and Storey, 2004), and temperature-dependent enzyme regulation (Storey, 1997; MacDonald and Storey, 1998; Thatcher and Storey, 2001). Maintenance of viable cellular energy status during torpor is important. Total adenylate levels in organs typically fall by about one-third during torpor but adenylate energy charge is maintained (MacDonald and Storey, 1999). Differential regulation of skeletal muscle creatine kinase, AMP deaminase and adenylate kinase contributes to regulating energetics at the high and low body temperatures that characterize euthermia versus hibernation (English and Storey, 2000; Abnous and Storey, 2007). Specific regulation of other enzymes involved in energy metabolism probably also contributes to the control of cellular energetics during torpor. One of these is HK because of its key role in gating sugar entry into glycolysis, the central ATP-producing pathway.

This chapter analyzes skeletal muscle HK from Richardson's ground squirrels, Spermophilus richardsonii, assessing the enzyme from euthermic and hibernating states with respect to kinetic parameters, reversible phosphorylation, and stability against denaturants to determine how the enzyme is regulated when the animals enter torpor.

\section{Materials and methods}

\section{Animals}

Protocols for care and handling of Richardson's ground squirrels, S. richardsonii, were essentially as reported previously (MacDonald and Storey, 1998; Thatcher and Storey, 2001). Briefly, animals were captured in late summer near Calgary, Alberta. All animals were individually housed in rat cages with free access to food and water at $22^{\circ} \mathrm{C}$ and on an autumn photoperiod (10 h light, $14 \mathrm{~h}$ dark). After 8 weeks under this regime, 
half of the animals were maintained under these control (euthermic) conditions. The others were moved into a $4^{\circ} \mathrm{C}$ cold room that was maintained in darkness; free access to water was maintained but food was removed. Squirrels were allowed to enter torpor and animals were sampled after $2 \mathrm{~d}$ continuous torpor (rectal temperature $5-8^{\circ} \mathrm{C}$ ). Euthermic animals were sampled on the same day. Both hibernating and euthermic animals were killed by decapitation and tissues were immediately excised, frozen in liquid nitrogen and then stored in $-80^{\circ} \mathrm{C}$.

\section{Preparation of tissue extracts}

Samples of hind leg skeletal muscle were homogenized 1:5 w:v in $50 \mathrm{mM}$ Tris buffer, $\mathrm{pH} 7.4$ containing $10 \mathrm{mM} \beta$-mecapthoethanol and inhibitors of protein phosphatases (30 $\mathrm{mM} \mathrm{NaF}$ ) and protein kinases ( $2 \mathrm{mM}$ EDTA, $2 \mathrm{mM}$ EGTA) with a few crystals of the protease inhibitor, phenylmethylsulfonyl fluoride (PMSF, $\sim 1 \mathrm{mM}$ ) added just prior to homogenization. Initial tests showed that $50 \mathrm{mM} \beta$-glycerophosphate, another inhibitor of protein phosphatases, inhibited HK activity by about $18 \%$ and so it was not routinely used. Homogenates were centrifuged at $25,000 \mathrm{~g}$ at $4^{\circ} \mathrm{C}$ for $30 \mathrm{~min}$ and then the supernatant was removed and stored on ice. Low molecular weight metabolites/ions were removed from the supernatant by a 2 min low speed centrifugation (2000 rpm) through small columns of Sephadex G15 equilibrated in homogenizing buffer. To assess the kinetic properties of $\mathrm{HK}$ bound to the particulate fraction, pellets were re-suspended in homogenization buffer, re-centrifuged, and the supernatant was removed. This washing procedure was repeated three times to make sure that there was no unbound HK left (as confirmed by assaying HK in the third wash). The final pellet 
was then re-suspended in $2 \mathrm{ml}$ of homogenization buffer and HK properties were assayed using aliquots of well-mixed suspension. In selected cases, the final pellets were resuspended in homogenization buffer $+150 \mathrm{mM} \mathrm{KCl}$ in order to release bound $\mathrm{HK}$ so that maximal activity of the bound enzyme could be quantified in a soluble state to determine the percentage of total HK that was bound to mitochondria.

\section{Enzyme assay}

Standard assays measured HK activity using a coupled enzyme assay with NADP-linked G6P dehydrogenase (G6PDH) and monitoring NADPH production at 340 nm using a Multiskan Spectrum microplate reader. Optimal assay conditions were 50 mM Tris buffer $\mathrm{pH} 7.4,5 \mathrm{mM}$ Mg.ATP, $5 \mathrm{mM}$ glucose, $10 \mathrm{mM} \mathrm{MgCh}, 1 \mathrm{mM}$ NADP and 1 unit G6PDH. To assess G6P inhibition of HK, enzyme activity was assayed instead by monitoring ADP production in a coupled assay system with pyruvate kinase (PK) and lactate dehydrogenase (LDH). For these assays, extracts that were partially purified using Sephacryl S-400 (see below) and assay conditions were $50 \mathrm{mM}$ Tris buffer $\mathrm{pH}$ 7.4, $5 \mathrm{mM}$ Mg.ATP, $5 \mathrm{mM}$ glucose, $20 \mathrm{mM} \mathrm{MgCh}, 4 \mathrm{mM}$ phosphoenolpyruvate, $0.225 \mathrm{mM}$ NADH, and $1 \mathrm{U}$ each of $\mathrm{LDH}$ and PK. Routine assays were run at $22^{\circ} \mathrm{C}$ and used $20 \mu 1$ of supernatant. $\mathrm{K}_{\mathrm{m}}$ values for glucose and Mg.ATP were determined at constant co-substrate concentrations, $5 \mathrm{mM} \mathrm{Mg}$.ATP or $5 \mathrm{mM}$ glucose. For studies of temperature effects on HK, the microplate reader was placed in an adjustable temperature incubator and the machine was allowed to equilibrate to the chosen temperature. Microplates were filled with assay mixture and then incubated in the reader until they equilibrated at the desired temperature, as indicated by thermistors placed in blank wells containing buffer. Assays 
were then started by the addition of enzyme and well temperatures were again measured at the end of the assay. Data are plotted as a function of mean well temperature at the beginning versus the end of the assay.

\section{Selective thermal inactivation of HKII}

In order to measure the activity of HKII in the ground squirrel muscle, we took advantage of the greater thermostability of mammalian HKI versus HKII isozymes. The method of Ritov and Kelley (2001) was applied to inactivate HKII in ground squirrel extracts. Extracts were incubated at $45^{\circ} \mathrm{C}$ for $60 \mathrm{~min}$ and then activity was measured as above and subtracted from the previously measured total HK activity to calculate HKII activity.

\section{Incubations to stimulate protein phosphatase or protein kinase activities}

Samples of Sephadex G25 filtered supernatant were incubated for $4 \mathrm{~h}$ at $22^{\circ} \mathrm{C}$ with specific inhibitors or stimulators of protein kinases or protein phosphatases as described previously (MacDonald and Storey, 1999). To assess the effects of protein kinase action on $\mathrm{HK}$, tissue extracts were prepared in stop buffer (50 mM Tris buffer, $\mathrm{pH}$ 7.4 containing $30 \mathrm{mM} \mathrm{NaF}, 2 \mathrm{mM}$ EDTA, $2 \mathrm{mM}$ EGTA, and $10 \mathrm{mM} \beta$-mecapthoethanol with a few crystals of PMSF) and then samples of supernatant were incubated in buffer containing $5 \mathrm{mM} \mathrm{Mg.ATP,} 30 \mathrm{mM} \mathrm{NaF}$, and $5 \mathrm{mM} \mathrm{Na}_{3} \mathrm{VO}_{4}$ with the further addition to stimulate specific kinases of $1 \mathrm{mM}$ cAMP for PKA, $1.3 \mathrm{mM} \mathrm{CaCl}$ and $7 \mu \mathrm{g} / \mathrm{mL}$ phorbol myristate acetate for PKC, $1 \mathrm{mM}$ cGMP for PKG, or $1 \mathrm{mM}$ AMP for AMPK. To assess protein phosphatase effects, tissue extracts were prepared in $50 \mathrm{mM}$ Tris- $\mathrm{HCl}$ buffer $\mathrm{pH}$ 
7.4, $10 \mathrm{mM} \beta$-mercapthoethanol (with PMSF added just before homogenization) and then aliquots of supernatant were incubated with $5 \mathrm{mM} \mathrm{MgCb}$ and $5 \mathrm{mM} \mathrm{CaCb}$ (to stimulate total protein phosphatases) with the further addition of specific inhibitors to assess individual phosphatases: (a) to assess total Ser/Thr phosphatase effects, the incubation also included $5 \mathrm{mM} \mathrm{Na}_{3} \mathrm{VO}_{4}$ to inhibit tyrosine phosphatases, (b) to assess protein phosphatase type 1 (PP1), $0.5 \mathrm{nM}$ okadaic acid (to inhibit PP2A), $2 \mathrm{mM}$ EDTA and 2 mM EGTA were included, (c) to assess protein phosphatase types $2 B$, the incubation contained $1 \mu \mathrm{M}$ okadaic acid, $5 \mathrm{mM} \mathrm{CaCb}$ and $2 \mathrm{mM}$ EDTA, and (d) to assess protein phosphatase $2 \mathrm{C}$, additions were $1 \mu \mathrm{M}$ okadaic acid, $5 \mathrm{mM} \mathrm{MgCb}$ and $2 \mathrm{mM}$ EGTA. As a control, tissue extracts were incubated under conditions that inhibited both protein kinases and phosphatases: $50 \mathrm{mM}$ Tris buffer, $\mathrm{pH} 7.4$ containing $30 \mathrm{mM} \mathrm{NaF}, 2 \mathrm{mM}$ EDTA, $2 \mathrm{mM}$ EGTA, and $10 \mathrm{mM} \beta$-mecapthoethanol with a few crystals of PMSF added. After incubation, low molecular weight metabolites and ions were removed from the extracts by low speed centrifugation ( $2 \mathrm{~min}, 2000 \mathrm{rpm}$ ) through small columns of Sephadex G25 equilibrated in homogenization buffer.

\section{Western blotting}

Skeletal muscle extracts were prepared as described above and soluble protein concentration was measured by the Coomassie blue dye binding method. Aliquots (100 $\mu 1)$ of extracts were mixed with $100 \mu \mathrm{l} 2 \mathrm{X}$ sample buffer (100 mM Tris buffer, $\mathrm{pH}$ 6.8, $4 \% \mathrm{w} / \mathrm{v}$ SDS, $20 \% \mathrm{v} / \mathrm{v}$ glycerol, $0.2 \% \mathrm{w} / \mathrm{v}$ bromophenol blue, $10 \% \mathrm{v} / \mathrm{v}$ fresh 2 mercaptoethanol) and then the mixtures were boiled for $5 \mathrm{~min}$, cooled on ice and frozen at $-80^{\circ} \mathrm{C}$ until use. Each lane of $10 \%$ SDS-PAGE gels was loaded with $20 \mu \mathrm{g}$ of protein 
and electrophoresis was carried out at $180 \mathrm{~V}$ for $50 \mathrm{~min}$. Proteins were transferred to polyvinylidene difluoride membrane at $70 \mathrm{~V}$ overnight. Membranes were then blocked with $5 \%$ non-fat dried milk in Tris-buffered saline containing the detergent Triton-X (TBST) for $120 \mathrm{~min}$ and washed three times with TBST. Membranes were incubated with primary antibody raised against muscle HKII (HK goat polyclonal IgG) (Santa Cruz) overnight at $4^{\circ} \mathrm{C}$. After washing with TBST, membranes were incubated with secondary antibody (mouse antigoat IgG) for $1.5 \mathrm{~h}$ and then washed. Immunoreactive bands were visualized with the enhanced chemoluminescence assay using a ChemiGenius (SynGene, MD, USA) and band intensities were quantified using the associated Gene Tools program.

\section{Column chromatography of HK}

DEAE Sephadex 50: Muscle extracts were prepared 1:5 w:v in homogenizing buffer (as above). A $500 \mu \mathrm{l}$ aliquot of crude extract was applied to a DEAE Sephadex G50 column $(1.5 \mathrm{~cm} \times 5 \mathrm{~cm})$ equilibrated in $50 \mathrm{mM}$ Tris- $\mathrm{HCl}$ buffer $\mathrm{pH} 7.0,30 \mathrm{mM} \mathrm{NaF}$, $2 \mathrm{mM}$ EDTA/EGTA, and $10 \mathrm{mM} \beta$-mercaptoethanol The column was washed with this buffer and then eluted with a linear gradient of $\mathrm{KCl}(0-400 \mathrm{mM})$ in the same buffer; fractions of $0.4 \mathrm{ml}$ were collected.

Sephacryl S-400 gel filtration: In order to examine G6P product inhibition of ground squirrel $\mathrm{HK}$, the PK/LDH coupling system was used to measure enzyme activity by ADP production. In crude extracts this resulted in background activity from glucoseindependent ATPases. Nonspecific ATPase activity was removed by applying a $2 \mathrm{ml}$ aliquot of crude extract to a Sephacryl S-400 column $(2 \mathrm{~cm} \mathrm{x} 80 \mathrm{~cm})$ equilibrated in 50 
$\mathrm{mM}$ Tris-HCl buffer $\mathrm{pH}$ 7.0, $30 \mathrm{mM}$ NaF, 2mM EDTA/EGTA, $10 \mathrm{mM} \beta$ -

mercaptoethanol. The column developed with the same buffer; after collecting a void volume of $50 \mathrm{~mL}, 0.8 \mathrm{~mL}$ fractions were collected and assayed for $\mathrm{HK}$ activity. Molecular mass markers run on the same column also allowed estimation of $\mathrm{HK}$ molecular weight.

\section{Pulse proteolysis}

The method of Park and Marqusee (2005) was used. Aliquots of $20 \mu 1(\sim 400 \mu \mathrm{g}$ total protein) of crude muscle extracts (1:5 w:v homogenization without PMSF) were incubated overnight at room temperature in $100 \mu 1$ of $50 \mathrm{mM}$ Tris buffer $\mathrm{pH} 7.5$ containing different concentrations of urea. After incubation, pulse proteolysis was initiated by adding thermolysin (Sigma) to a final concentration of $0.40 \mathrm{mg} / \mathrm{ml}$ (stock thermolysin was prepared in 50mM Tris $\mathrm{pH} 7,2.5 \mathrm{M} \mathrm{NaCl} 10 \mathrm{mM} \mathrm{CaCl}$ ). After $10 \mathrm{~min}$ incubation, the reaction was quenched by adding $18 \mu 1$ of $50 \mathrm{mM}$ EDTA (pH 8.0). Each sample was then subjected to Western blotting as described above to measure the amount of folded protein remaining.

\section{Data, statistics and protein determination}

Enzyme rates were analyzed with a Microplate Analysis program (Brooks, 1994) and kinetic parameters were determined using a nonlinear least squares regression computer program (Kinetics 3.51) fully described in (Brooks, 1992). This program fitted the data to $\mathrm{v}=\mathrm{Vmax} \times[\mathrm{S}]^{\mathrm{h}} /\left(\mathrm{S}_{0.5}{ }^{\mathrm{h}}+[\mathrm{S}]^{\mathrm{h}}\right)$ using a nonlinear, least squares regression algorithm (Marquardt-Levengberg) to find the minimum sum of squares. The number of iterations used was 4 . To test the goodness-of-fit, the program does two nonparametric 
tests (run test, sign test). These tests showed that the sequence of residuals and number of + and - residuals was random at $\mathrm{P}<0.05$. Parameters with standard deviation of more than ten percent were discarded

Data are expressed as mean \pm S.E.M. from multiple independent determinations of kinetic parameters on separate preparations of enzyme. Statistical testing performed using the Student's ttest or analysis of variance followed by a Dunnett's test. Protein concentration was determined by the Coomassie blue G-250 dye binding method using the Bio-Rad Laboratories prepared reagent and bovine serum albumin as the standard.

\section{Results}

\section{Kinetic analysis of ground squirrel muscle HK}

Maximum activities of $\mathrm{HK}$ were measured in soluble extracts of ground squirrel skeletal muscle; mean values were $173.7 \pm 2.7$ milliunits/gram wet weight (mU/gww) in muscle from euthermic squirrels and $116.5 \pm 3.8 \mathrm{mU} / \mathrm{gww}$ in hibernating squirrels (mean \pm SEM, $n=7$ ), about $33 \%$ lower than in euthermia. Crude preparations of HK stored at $5^{\circ} \mathrm{C}$ were stable up to 4 days and the $\mathrm{pH}$ optimum of $\mathrm{HK}$ was determined to be 7.2 (Fig. 2-1). Velocity versus substrate concentration curves for muscle HK in crude extracts from both euthermic and hibernating ground squirrels are shown in Fig. 2-2 and $\mathrm{K}_{\mathrm{m}}$ values are summarized in Table 2-1. The relationships were hyperbolic in all cases. The $\mathrm{K}_{\mathrm{m}}$ ATP was $80 \%$ higher and significantly different $(\mathrm{P}<0.05)$ for the hibernator enzyme, compared with euthermic HK. By contrast, the $\mathrm{K}_{\mathrm{m}}$ value for glucose did not differ between euthermic and hibernating states.

Muscle $\mathrm{HK}$ is known to bind to mitochondria and a portion of total $\mathrm{HK}$ remains in 
the pellet under normal homogenization and centrifugation conditions. Re-extraction of the pellet was used to remove any unbound $\mathrm{HK}$ and then bound $\mathrm{HK}$ was characterized in resuspended pellets. Fig. 2-3 shows that there was no significant difference in the activity of the bound portion of $\mathrm{HK}$ in euthermic and hibernating animals (about $5 \mathrm{mU} / \mathrm{mg}$ protein in both cases), with bound HK representing $15.4 \% \pm 0.6 \%$ of total $\mathrm{HK}$ in euthermic muscle and $14.6 \% \pm 2.0 \%$ in hibernation. Kinetic analysis found that the $\mathrm{K}_{\mathrm{m}}$ ATP of bound HK was not significantly different from the corresponding value for soluble HK in either the euthermic or hibernating situations (Table 2-1, Fig. 2-2C). However, bound euthermic $\mathrm{HK}$ showed a $30 \%$ reduction in $\mathrm{K}_{\mathrm{m}}$ for glucose as compared with the soluble enzyme $(\mathrm{P}<0.05)$ (Table 2-1, Fig. 2-2D).

\section{Temperature effects on HK}

Arrhenius plots showing the effect of temperature on HK activity are shown in Fig. 2-4. The relationship was linear over the range of temperatures tested $\left(2-30^{\circ} \mathrm{C}\right)$ for HK from both euthermic and hibernating muscle. Calculated activation energy, Ea, for HK from euthermic ground squirrels was $50.6 \pm 0.7 \mathrm{~kJ} / \mathrm{mol}$ versus $51.9 \pm 0.6 \mathrm{~kJ} / \mathrm{mol}$ $(\mathrm{n}=5)$ for hibernator $\mathrm{HK}$ (not significantly different). Low temperature assay at $5^{\circ} \mathrm{C} \mathrm{did}$ not affect the $K_{m}$ ATP of euthermic HK but decreased the $K_{m}$ of hibernator HK to $43 \%$ of the value at $22^{\circ} \mathrm{C}$. The effect of low temperature assay on $\mathrm{K}_{\mathrm{m}}$ glucose was the opposite, lowering the $\mathrm{K}_{\mathrm{m}}$ of euthermic $\mathrm{HK}$ to $54 \%$ of the value at $22^{\circ} \mathrm{C}$ but having no effect on the enzyme from hibernating animals.

\section{Inhibition of HK by G6P}

To assess G6P inhibition, Sephacryl S-400 gel filtration was first used to remove 
background ATPase activity so that glucose-dependent ATP hydrolysis could be more easily measured. A major peak of $\mathrm{HK}$ eluted from the column at about $90 \mathrm{~mL}$ and was confirmed to be HK by (a) its glucose-dependence, (b) detection of the same peak when the G6PDH coupling enzyme assay was used, and (c) elution of the ground squirrel HK peak at $\sim 104 \mathrm{kDa}$, consistent with the known molecular weight of mammalian HK.

G6P is a product inhibitor of $\mathrm{HK} . \mathrm{K}_{\mathrm{m}}$ glucose values were measured at different concentrations of G6P and used to determine $K_{i}$ values for G6P (Fig. 2-5). The $K_{i}$ G6P for muscle HK from euthermic ground squirrels was $0.48 \pm 0.09 \mathrm{mM}(\mathrm{n}=4)$. G6P was a stronger inhibitor of hibernator $\mathrm{HK}$ with a $\mathrm{K}_{\mathrm{i}}$ value that was $40 \%$ lower at $0.29 \pm 0.08$ $\mathrm{mM}(\mathrm{n}=4)(\mathrm{P}<0.05)$.

\section{HK protein levels}

Western blotting was used to evaluate the relative amount of HK protein in muscle from euthermic versus hibernating ground squirrels. Antibodies detecting mammalian HK II showed a significant reduction in HK protein during hibernation. The amount of HK protein in muscle from hibernating animals was $80 \pm 2 \%(n=8, P<0.05)$ of the euthermic value.

\section{Reversible phosphorylation of HK}

We hypothesized that protein phosphorylation might be the mechanism underlying the stable kinetic differences between HK from euthermic and hibernating muscle that were seen in Table 2-1. To determine if this was the case, muscle extracts were incubated under conditions that stimulated the actions of endogenous protein phosphatases or protein kinases (Fig. 2-6) and the resulting effects on HK activity and kinetic properties were measured. Fig. 2-6a shows the effect of incubating HK under 
conditions that stimulated the actions of various protein phosphatases. Incubation of extracts under conditions that stimulated protein phosphatases generally decreased the activity of $\mathrm{HK}$ in extracts from both euthermic and hibernating animals. For HK in euthermic extracts, the decrease was $10-38 \%(\mathrm{P}<0.05)$ after incubations that stimulated total protein phosphatases, serine/threonine phosphatases, PP1 or PP2B (Fig. 2-6a) whereas conditions that stimulated $\mathrm{PP} 2 \mathrm{C}$ did not affect $\mathrm{HK}$ activity. Extracts from hibernating muscle incubated under the same conditions also showed reductions in $\mathrm{HK}$ activity by $17-32 \%(\mathrm{P}<0.05)$ in all cases except under conditions that stimulated PP2C.

By contrast, incubation of euthermic extracts under conditions that stimulated the activities of endogenous protein kinases (PKA, PKC, PKG or AMPK) did not change HK activity (Fig. 2-6b). However, stimulation of AMPK significantly increased HK activity by $10 \%$ in hibernator extracts $(\mathrm{P}<0.05)$.

Incubations that stimulated AMPK also altered the apparent affinity of hibernator HK for ATP but not for glucose (Fig. 2-2e,f). AMPK treatment reduced $\mathrm{K}_{\mathrm{m}}$ ATP to the value seen for soluble euthermic HK (Table 2-1). However, although stimulation of protein phosphatases strongly affected HK maximal activity in euthermic extracts (Fig. 26a), the $K_{m}$ values for ATP and glucose of PP1-treated HK in euthermic extracts were not different from those of untreated controls (Table 2-1).

\section{Ion exchange chromatography of HK}

Ion exchange chromatography separates proteins based on their electrical charge and is frequently used to separate isozymes or enzyme forms that have been covalently modified by reversible phosphorylation. Fig. 2-7 shows the elution patterns of soluble HK activity from DEAE-Sephadex 50 using a $0-400 \mathrm{mM} \mathrm{KCl}$ gradient to compare the 
enzyme from skeletal muscle of euthermic versus hibernating Richardson's ground squirrels. In extracts of euthermic muscle, HK eluted in a single peak whereas the enzyme in hibernator extracts showed two distinctly separated peaks (Fig. 2-7a). The second peak in the hibernator extract eluted at the same salt concentration as did HK in euthermic extracts. Fig. $2-7 \mathrm{~b}$ shows the results after incubations under conditions that stimulated either PP1 or AMPK activities. When euthermic HK was incubated under conditions that stimulated PP1 activity, the peak shifted to elute at a lower $\mathrm{KCl}$ concentration (as would be expected after removal of charged phosphate groups from a protein), equivalent to the position of peak I HK in hibernator extracts. By contrast, stimulation of hibernating extracts with AMPK shifted all HK activity into Peak II. Hence, these data are consistent with peak I being a low phosphate (dephosphorylated) form of $\mathrm{HK}$ whereas peak II is a higher phosphate (phosphorylated) form. $\mathrm{K}_{\mathrm{m}}$ values for both HK substrates of the peak I and II enzymes were analyzed and were found to be the same as the values see in Table 2-1 for HK from PP1-treated euthermic HK and untreated euthermic HK, respectively.

\section{Selective inactivation of HKII}

Mammalian skeletal muscle typically contains a mixture of HKI and HKII isozymes and we aimed to determine which isozyme dominated in ground squirrel muscle. To evaluate the isozyme composition of ground squirrel muscle we exploited the known characteristics of the mammalian isozymes. Differential thermal sensitivity to heating has been described for HKI and HKII (Ritov and Kelley, 2001). Fig. 2-8 shows the effects of incubation at $45^{\circ} \mathrm{C}$ for $60 \mathrm{~min}$ (a treatment that should inactivate HKII without affecting $\mathrm{HKI}$ ) on $\mathrm{HK}$ activity in muscle extracts from euthermic and hibernating 
ground squirrels. Heating strongly reduced total $\mathrm{HK}$ activity in both extracts, leaving just 6.4 and $2.4 \%$ of the original activity in euthermic and hibernating extracts, respectively. Hence, these results indicate that HKI comprises just $\sim 7 \%$ of the total $\mathrm{HK}$ content of ground squirrel skeletal muscle. Therefore, these experiments show that the kinetic parameters measured in the present study must primarily represent HKII. Moreover, with only a minor component of HKI present, it is evident that the two major peaks of HK activity that were separated via DEAE column chromatography must represent different phosphorylation states of HKII and not two isozymic forms of HK. Hence, the DEAE column (Fig. 2-7a) indicates that almost 50\% of HKII is phosphorylated during hibernation

\section{Structural stability of ground squirrel HK}

The structural stability of HK was investigated by evaluating its sensitivity to urea denaturation followed by pulse proteolysis with thermolysin which preferentially digests unfolded, denatured proteins. The amount of native protein remaining was then assessed by Western blotting. Applying this method developed by Park and Marqusee (2005) to ground squirrel $\mathrm{HK}$, we found that $\mathrm{HK}$ in hibernator extracts was substantially more stable to urea denaturation than was the euthermic enzyme (Fig. 2-9). The calculated $\mathrm{Cm}$ value (concentration of urea that results in $50 \%$ loss of folded HK) was $3.77 \pm 0.20 \mathrm{M}$ for $\mathrm{HK}$ in hibernator extracts, significantly higher than the value of $2.96 \pm 0.50 \mathrm{M}$ for $\mathrm{HK}$ in euthermic extracts $(\mathrm{P}<0.05)$. 
Table 2-1. $\mathrm{K}_{\mathrm{m}}$ values for substrates of skeletal muscle HK from euthermic versus hibernating Richardson's ground squirrels. Incubations to stimulate protein phosphatase type 1 (PP1) or AMP-dependent protein kinase (AMPK) were as described in the Materials and Methods. Data are means \pm SEM, $n=4$; except where indicated, assays were conducted at $22^{\circ} \mathrm{C}$.

\begin{tabular}{lll}
\hline & $\mathrm{K}_{\mathrm{m}} \mathrm{ATP}(\mathrm{mM})$ & $\mathrm{K}_{\mathrm{m}}$ Glucose $(\mathrm{mM})$ \\
\hline Euthermic & $1.60 \pm 0.08$ & $0.13 \pm 0.003$ \\
Euthermic bound HK & $1.90 \pm 0.17$ & $0.09 \pm 0.01^{\mathrm{a}}$ \\
Euthermic (PP1-treated) & $1.56 \pm 0.07$ & $0.15 \pm 0.02$ \\
Euthermic at $5^{\circ} \mathrm{C}$ & $1.71 \pm 0.02$ & $0.07 \pm 0.01^{\mathrm{a}}$ \\
& & \\
Hibernating & $2.92 \pm 0.025^{\mathrm{a}}$ & $0.12 \pm 0.003$ \\
Hibernating bound HK & $2.61 \pm 0.44^{\mathrm{a}}$ & $0.10 \pm 0.02$ \\
Hibernating (AMPK-treated) & $1.56 \pm 0.14^{\mathrm{b}}$ & $0.13 \pm 0.02$ \\
Hibernating at $5^{\circ} \mathrm{C}$ & $1.25 \pm 0.10^{\mathrm{a}, \mathrm{b}}$ & $0.11 \pm 0.01$ \\
\hline
\end{tabular}

a - Significantly different from the corresponding value for soluble euthermic HK at $22^{\circ} \mathrm{C}, \mathrm{P}<0.05 ;^{\mathrm{b}}$ - significantly different from the corresponding value for soluble hibernating $\mathrm{HK}$ at $22^{\circ} \mathrm{C}, \mathrm{P}<0.05$. 
Fig. 2-1. Effect of $\mathrm{pH}$ on the activity of skeletal muscle HK from euthermic ground squirrels. Data are means $\pm \mathrm{SEM}, \mathrm{n}=4$ independent determinations on different preparations of enzyme; where error bars are not visible they are within the dimensions of the symbol. 
Figure 2-1

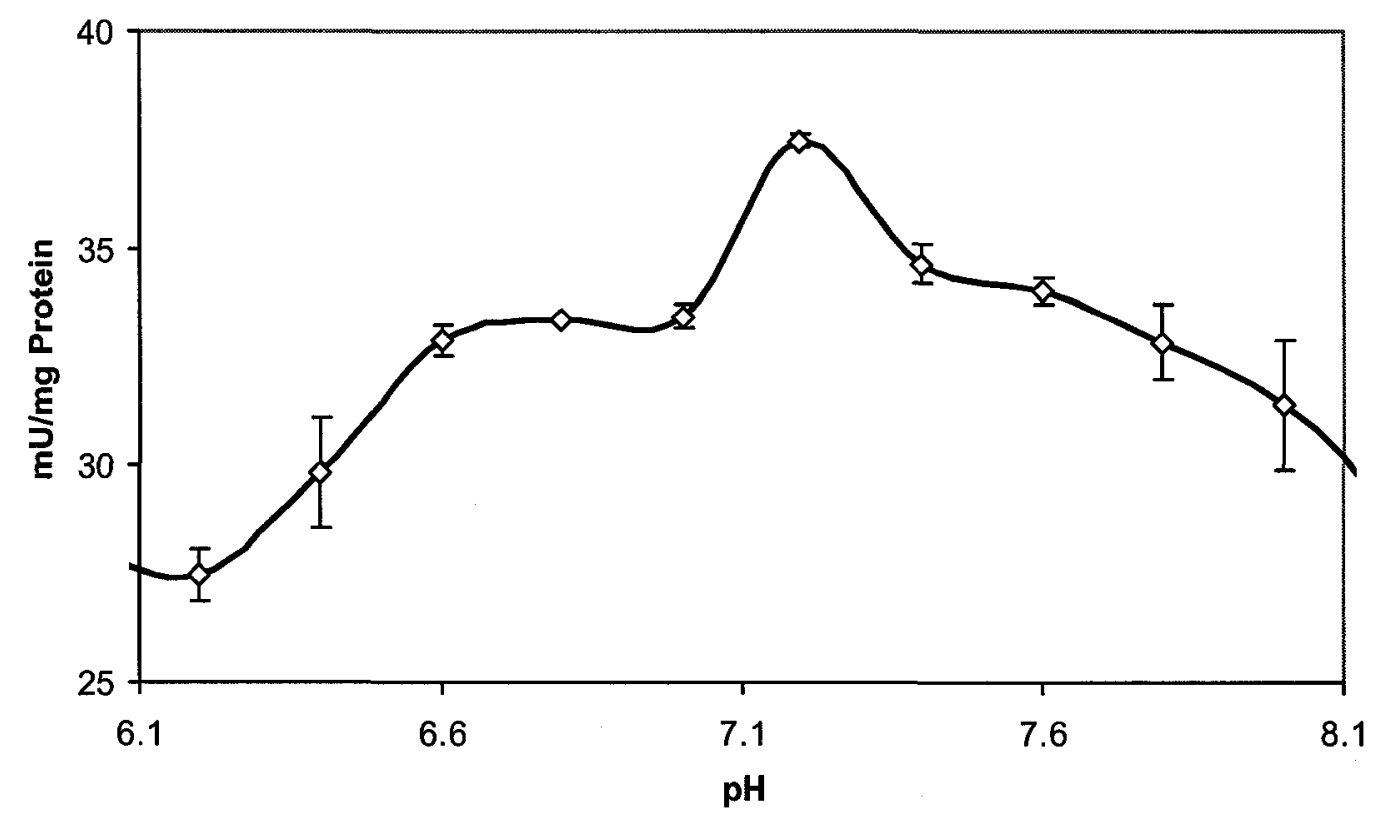


Fig. 2-2. Activity versus substrate concentration relationships for ground squirrel muscle HK showing data for free $\mathrm{HK}$ in crude extracts from euthermic (diamonds) and hibernating (squares) animals. A: Effect of variation in ATP concentrations. B: Effect of variation in glucose concentrations. C: Effect of variation in ATP concentrations on bound HK. D: Effect of variation in glucose concentration on bound HK. E and F: Effect of incubating tissue extracts under conditions that stimulate protein phosphatase type 1 (PP1) activity in euthermic extracts or stimulate AMP-dependent protein kinase (AMPK) in hibernating extracts on the HK activity versus ATP profile (E) and activity versus glucose profile (F). Data are milliunits/mg protein, mean \pm SEM, $n=5$ independent determinations on different preparations of enzyme; where error bars are not visible they are within the dimensions of the symbol. 
Figure 2-2
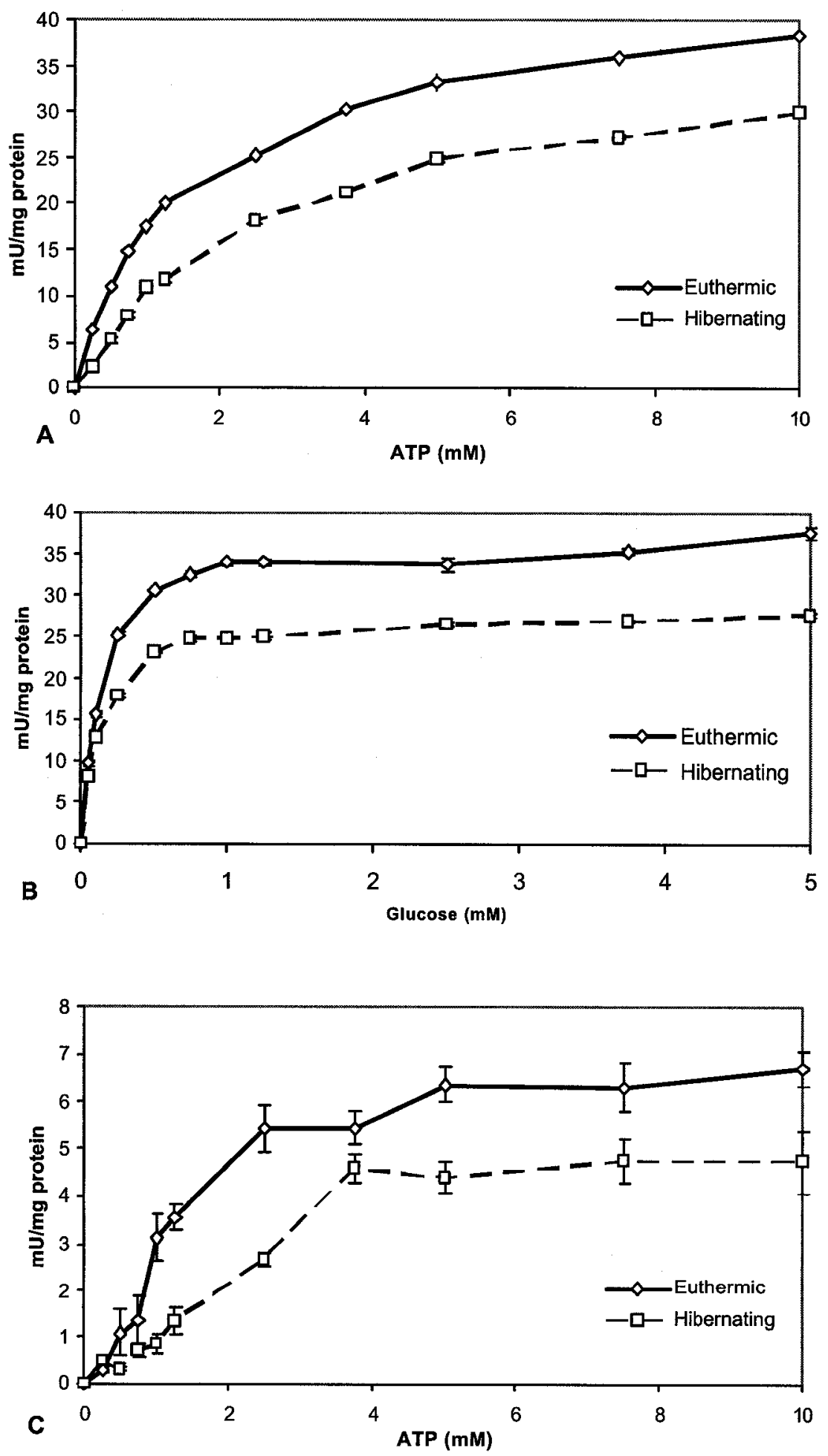
Figure 2-2 continued
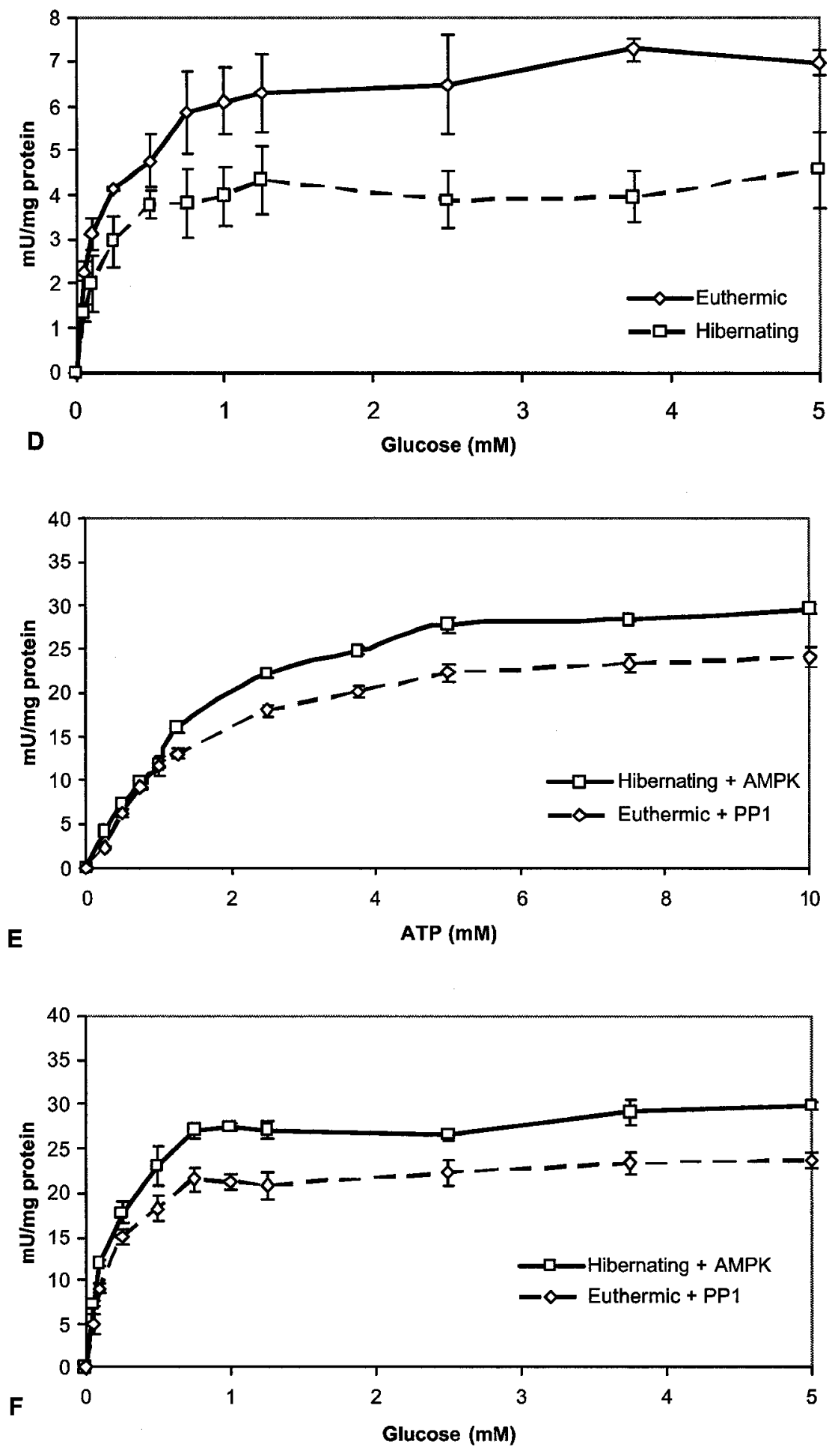
Fig. 2-3. Distribution of HK between cytoplasmic and bound states in skeletal muscle extracts of euthermic and hibernating Richardson's ground squirrels. Total HK is cytoplasmic HK + bound HK. Activity of bound HK was measured after treatment of pellets with $0.15 \mathrm{M} \mathrm{KCl}$ to release the enzyme. Data are means $\pm \mathrm{SEM}, \mathrm{n}=4$ independent determinations on different preparations of enzyme. * Significantly different from the corresponding euthermic value, $\mathrm{P}<0.05$. 
Figure 2-3.

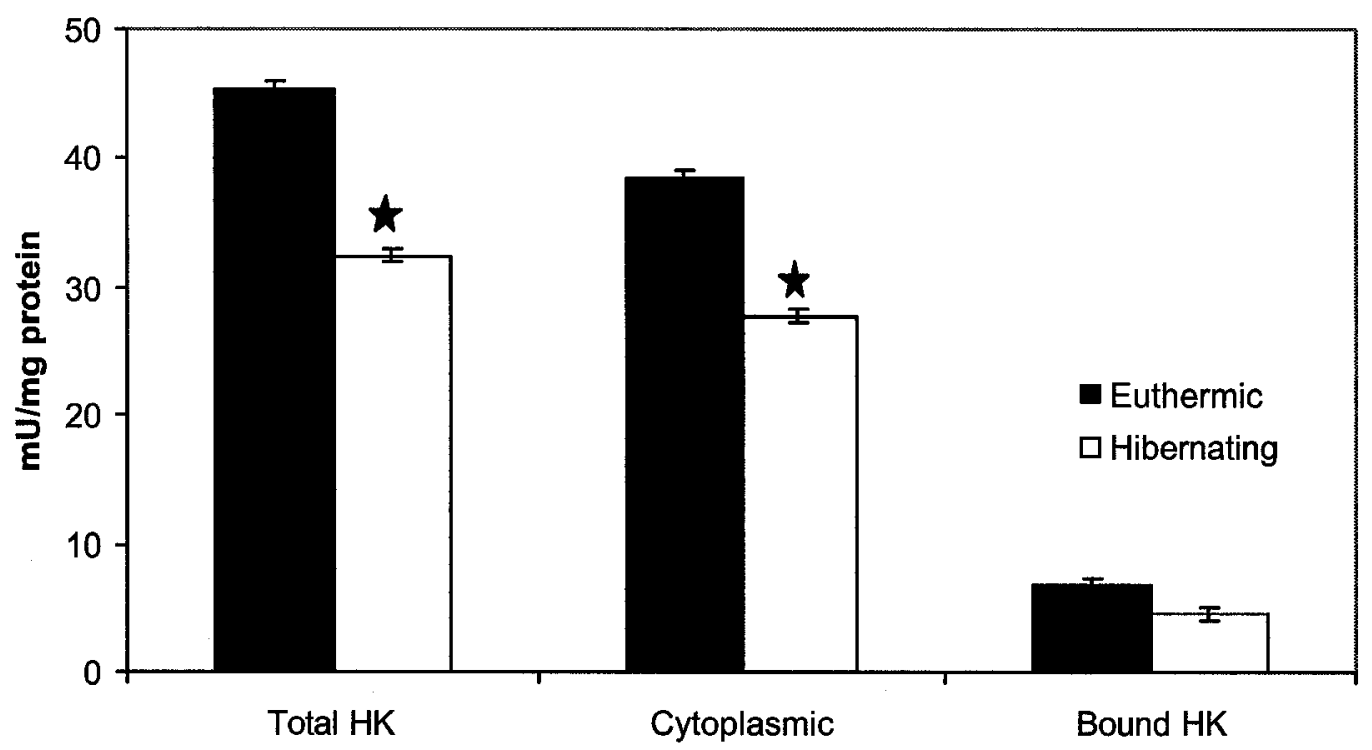


Fig. 2-4. Arrhenius plots for HK from skeletal muscle of euthermic (diamonds) and hibernating (squares) ground squirrels. Data are means $\pm S E M, n=5$ independent determinations on different preparations of enzyme. 
Figure 2-4.

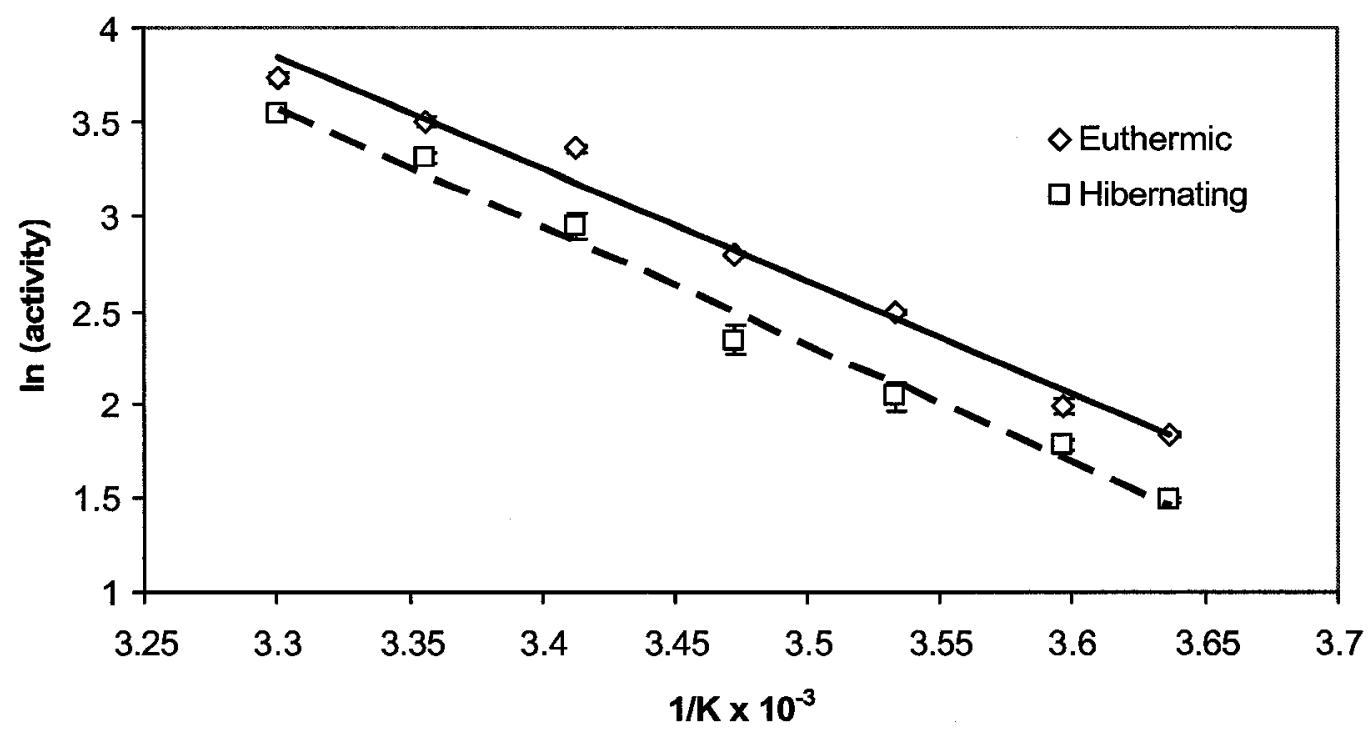


Fig. 2-5. Inhibition of ground squirrel muscle HK by G6P; data show the relationship between $K_{m}$ glucose and glucose-6-phosphate (G6P) concentration to determine a $K_{i}$ for G6P. Data are means \pm SEM, $n=5$ independent determinations on different preparations of enzyme. Symbols are: euthermic (diamonds), hibernating (squares). 
Figure 2-5.

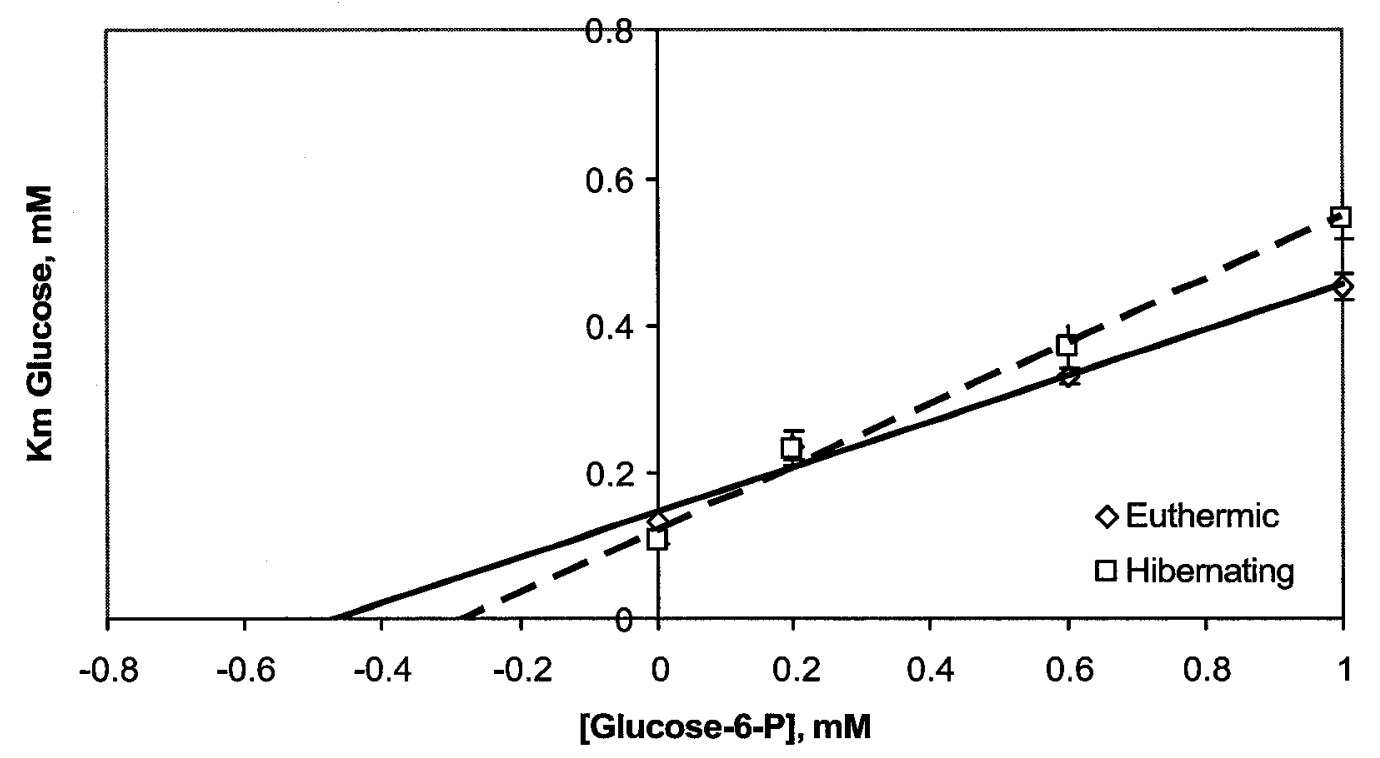


Fig. 2-6. Effect of in vitro incubations of ground squirrel muscle extracts under conditions that promote the action of protein phosphatases or protein kinases on the activity of HK. A: Effect of stimulating endogenous protein phosphatases including total protein phosphatases (PPt), total Ser/Thr PPs (TST), PP1, PP2B and PP2C. B: Effect of stimulating endogenous protein kinases including PKA, PKC, PKG or AMPK. Enzyme extracts were incubated at $22^{\circ} \mathrm{C} \mathrm{h}$ for $4 \mathrm{~h}$ under conditions as outlined in the Material and Methods and then HK was assayed under optimal conditions. Data are means \pm SEM, $\mathrm{n}=6$ independent determinations on different preparations of enzyme. * - Significantly different from the corresponding euthermic control (no additions) activity using the Student's t-test, $\mathrm{P}<0.05 ;+$ - significantly different from the corresponding hibernating control, $\mathrm{P}<0.05$. 
Figure 2-6.
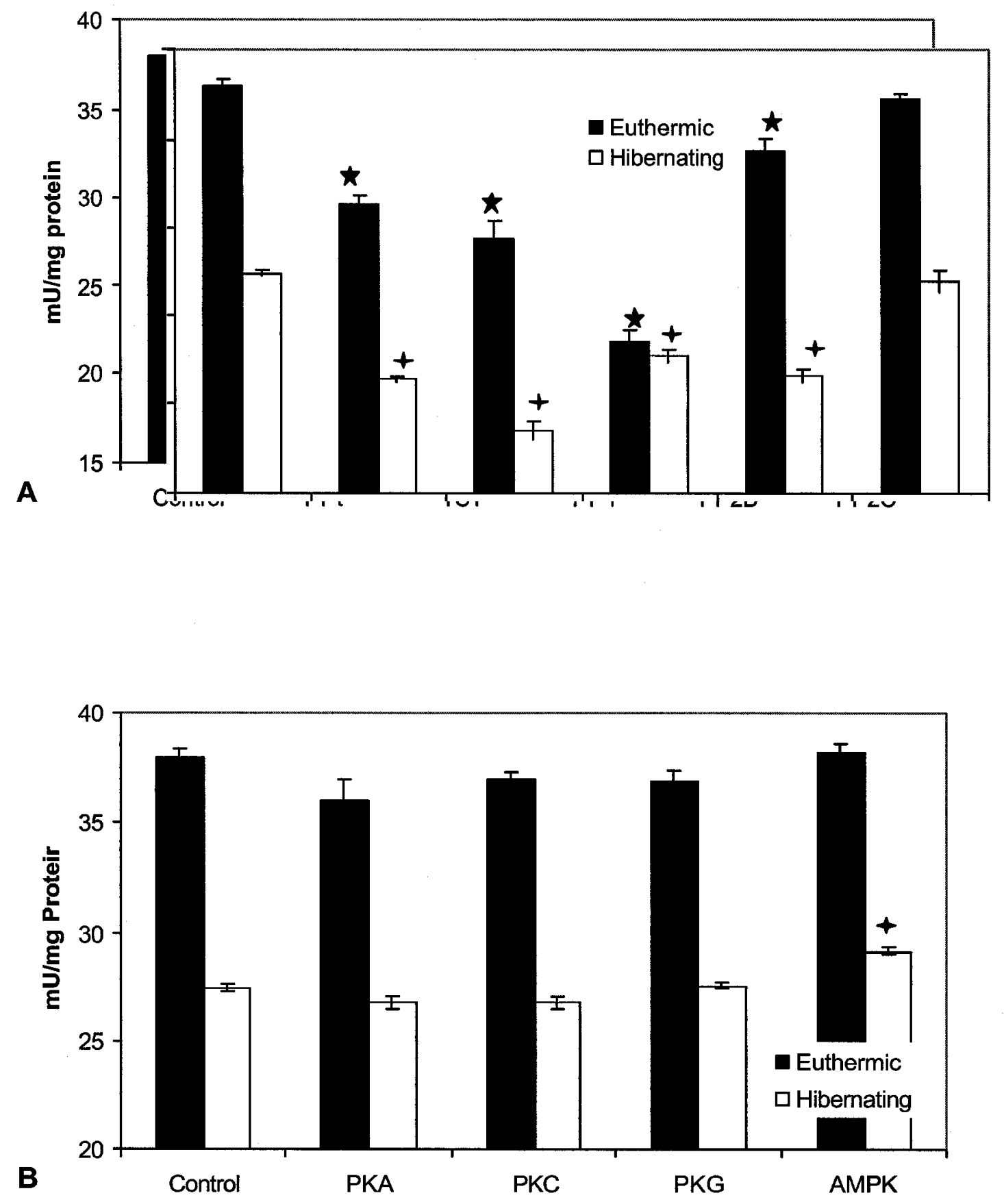
Fig. 2-7. Column chromatography of ground squirrel skeletal muscle HK. A. DEAE Sephadex ion exchange chromatography of HK in extracts from euthermic and hibernating animals. The column was equilibrated in $50 \mathrm{mM}$ Tris- $\mathrm{HCl}$ buffer $\mathrm{pH} 7.0$ (containing $30 \mathrm{mM} \mathrm{NaF}, 2 \mathrm{mM}$ EDTA/EGTA, $10 \mathrm{mM} \beta$-mercaptoethanol) and developed using a $0-400 \mathrm{mM} \mathrm{KCl}$ gradient in the same buffer. B: DEAE Sephadex elution profile of HK in extracts from hibernating animals after incubation under conditions that stimulated AMPK and in extracts from euthermic animals after incubation under conditions that stimulated PP1 action. Data show representative profiles for single preparations but the same separations were achieved in multiple $(n=3)$ trials. 
Figure 2-7.
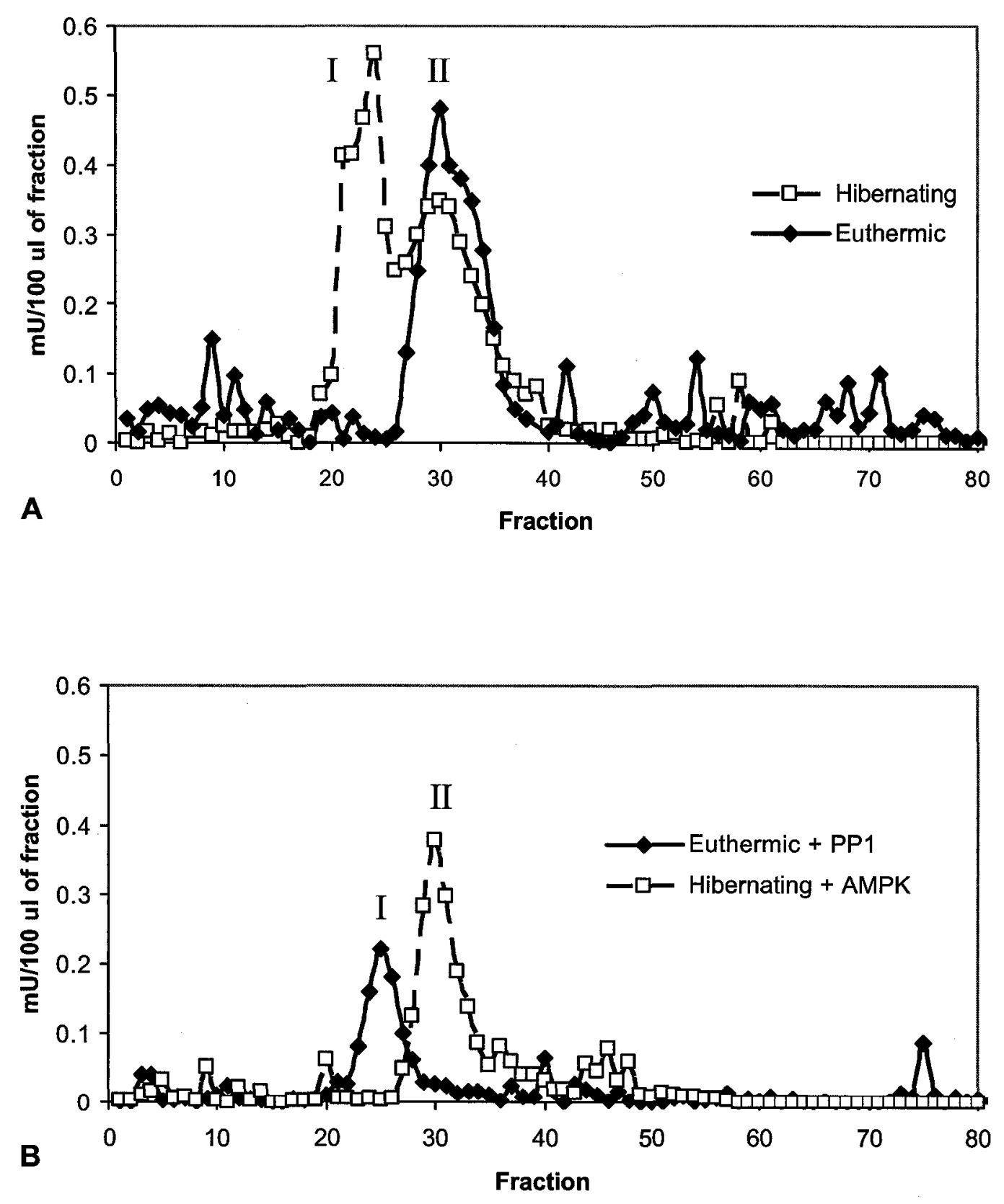
Fig. 2-8. Selective thermal inactivation of HKII after incubation at $45^{\circ} \mathrm{C}$ for $60 \mathrm{~min}$. Data are means \pm SEM, $n=3$ independent determinations on different preparations of enzyme. 
Figure 2-8.

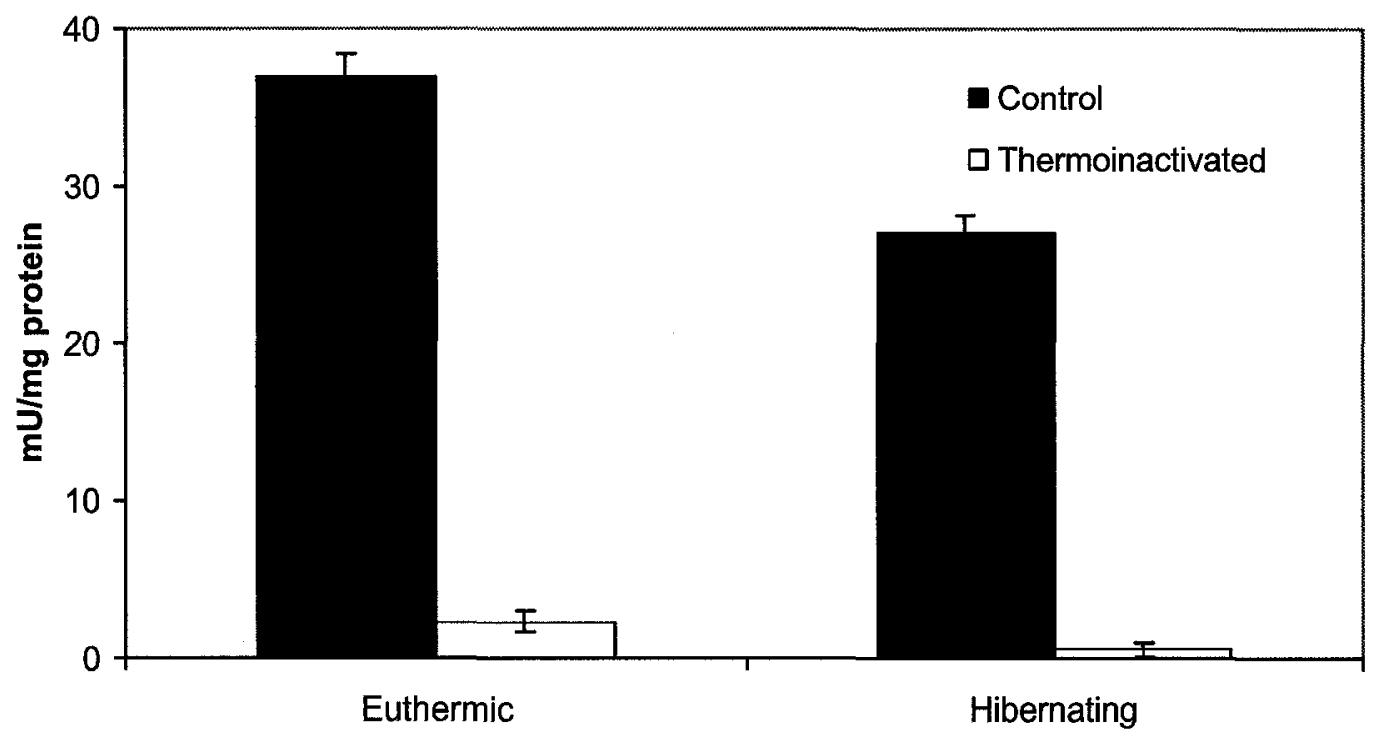


Fig. 2-9. Stability of HK II from crude extracts of euthermic or hibernating muscle as a function of urea concentration. Samples were incubated for $24 \mathrm{~h}$ with different concentrations of urea and then treated with pulse proteolysis ( 1 min incubation with thermolysin) to degrade denatured HK II; Western blotting was then used to measure the amount of native folded HK II protein remaining. Data are means $\pm S E M, n=4$; where error bars are not visible they are within the dimensions of the symbol. 
Figure 2-9.

\section{Euthermic}

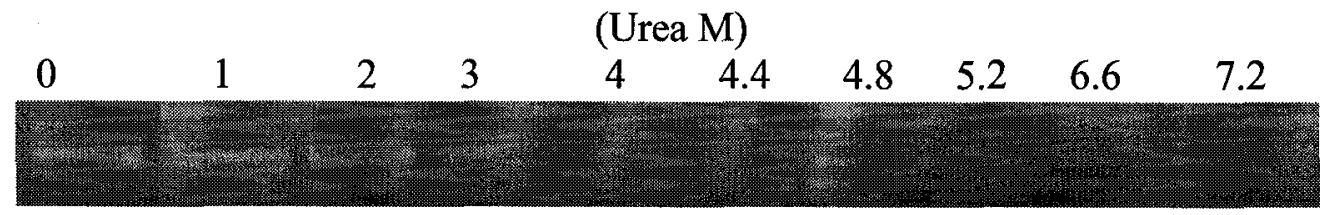

Hibernating
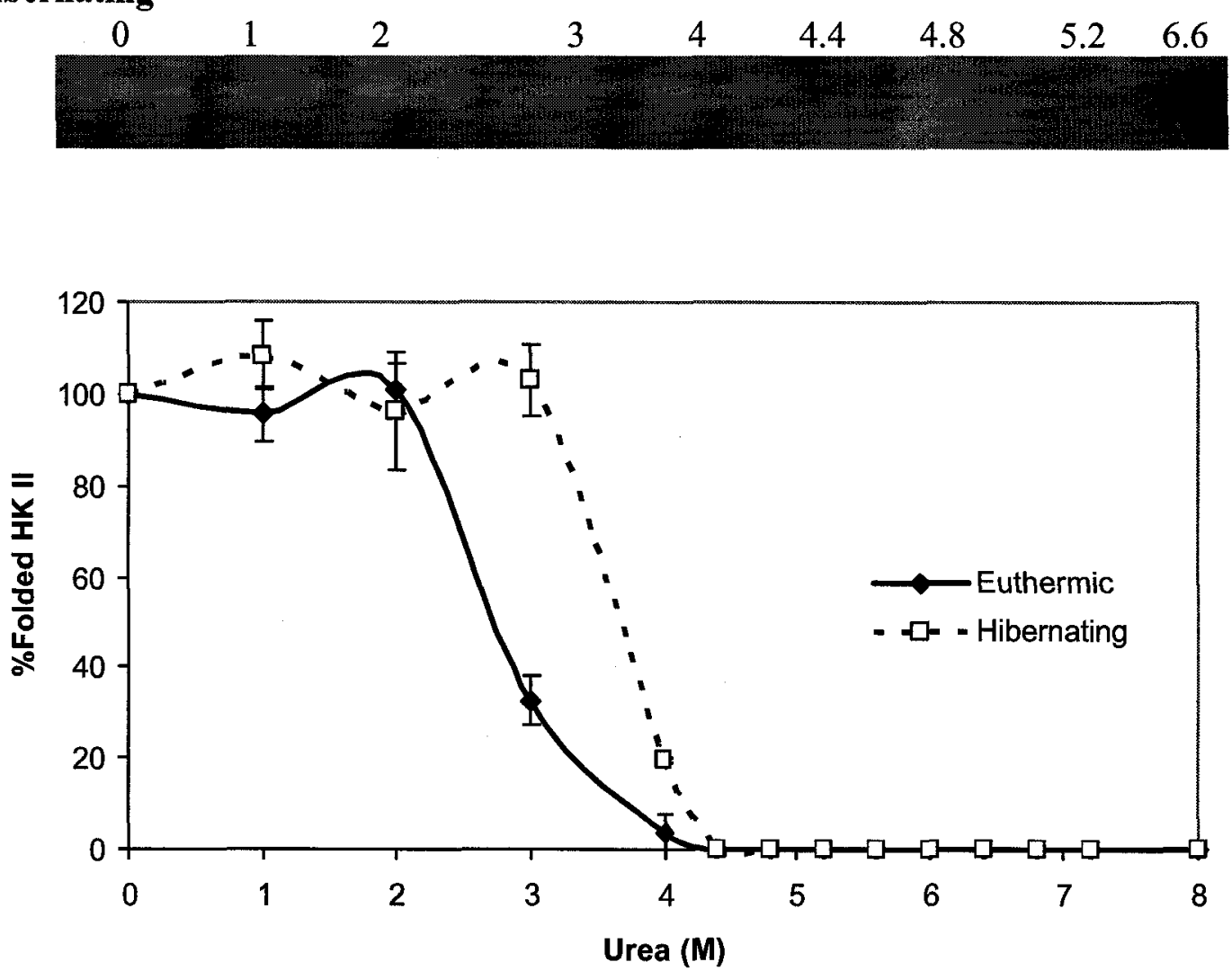


\section{Discussion}

During winter hibernation, small mammals have to cope with food limitation and cold ambient temperature. By entering torpor and dropping body temperature to near ambient, they greatly reduce the total amount of metabolic fuel needed and greatly extend the time that body reserves can support survival. Hibernation requires multiple metabolic adaptations and regulatory controls to address many issues including metabolic rate depression, low temperature function, reorganization of metabolic fuel use and of priorities for ATP expenditure, and differential expression of genes/proteins with specific protective functions (Storey, 1997, 2003). Of particular interest are the mechanisms that coordinate entry into or arousal from torpor and that maintain integrated metabolism at the very low body temperatures that would cause lethal hypothermia in most nonhibernating mammals. Tight metabolic regulation is needed to enter, sustain, and arouse from torpor. Although lipids are the primary fuel for most organs during hibernation, some organs (e.g. brain) still rely strongly on carbohydrate catabolism and all tissues have basal needs for carbohydrate. In skeletal muscle this could include a contribution by carbohydrate catabolism to ATP production in support of shivering thermogenesis during arousal from torpor.

As the first enzyme involved in the processing of glucose, regulation of $\mathrm{HK}$ is central to carbohydrate metabolism in all tissues and its response and control during hibernation is of great interest. Ritov and Kelley (2001) reported that both HKI and HKII were found in the cytoplasm of human skeletal muscle. The same group found that HKI was the sole enzyme found in rat muscle. Our thermal inactivation studies indicated that HKII was the major isozyme in ground squirrel muscle with HKI comprising only $\sim 6 \%$ 
of the total in euthermic muscle. Hexokinase maximal activity in ground squirrel skeletal muscle was reduced by about $33 \%$ during hibernation as compared with activity in euthermic muscle (when both were assayed at room temperature). Kinetic analysis also showed that HK from these two physiological conditions differed in its substrate apparent affinity for ATP and in its sensitivity to G6P inhibition. $\mathrm{K}_{\mathrm{m}}$ ATP was $\sim 80 \%$ higher during hibernator, compared with euthermic muscle, when the enzymes were compared at $22^{\circ} \mathrm{C}$ (Table 2-1). However, this was reversed when hibernator $\mathrm{HK}$ was assayed at $5^{\circ} \mathrm{C}$ where the $K_{m}$ ATP values were the lowest of any of the situations that were tested. This high apparent affinity of hibernator HK for ATP at cold temperatures may have functional significance for sustaining $\mathrm{HK}$ function during torpor because skeletal muscle concentrations of ATP also drop by about one-third when animals hibernate (MacDonald and Storey, 1998; English and Storey, 2000).

As noted above, most of the HK in hibernator muscle appeared to be the HKII isozyme. Wilson (1995) showed that inorganic phosphate inhibits type II HK and this finding was interpreted as indicating that this $\mathrm{HK}$ cannot be in the catabolic pathway that ends with the production of inorganic phosphate. Hence, it appears that HKII is related to the anabolic uses of glucose including the production of G6P for glycogen synthesis or for use by the pentose phosphate pathway (Wilson, 2003). Both functions would be useful in hibernators. Activation of shivering thermogenesis during arousal would likely involve at least some glycogen consumption which would need replacement before the next torpor bout. Arousal is also a time of high oxidative stress, and glucose/glycogen consumption by the pentose phosphate pathway would be called upon to generate NADPH for antioxidant defense mechanisms. 
Our study found that the amount of activity recovered as mitochondrial bound HK was the same in both euthermic and hibernating animals. Binding to mitochondria did not change HK apparent affinity for ATP and glucose in hibernating animals as compared to free HK but bound euthermic HK did now increased apparent affinity for glucose as compared with the free enzyme. Binding increases access by HK to intramitochondrial ATP (Rose and Warms, 1967) and, for hibernators, sustaining the compartmentation of HK probably allows for efficient ATP usage during torpor. Furthermore, binding of HKII to mitochondria has been shown to protect against a loss of cell viability due to apoptosis (Pastorino et al., 2005). The mechanism appears to be HK interaction with voltagedependent anion channels to maintain them in a conformation that does not allow the release of cytochrome $\mathrm{c}$ from the mitochondria. Indeed, mechanisms of apopotosis inhibition are beginning to receive considerable study in systems of natural hypometabolism where viability must be sustained over the long term in a situation where ATP availability and the capacity of biosynthetic repair/replacement are extremely limited. Maintenance of HK binding to mitochondria during prolonged torpor could therefore be an indicator of sustained viability during torpor.

The data in this chapter indicates that direct phosphorylation of HKII may contribute to the regulation of the enzyme. Incubations under conditions that stimulated several different protein kinases (PKA, PKC, PKG, AMPK) did not significantly affect HK maximal activity in euthermic muscle but AMPK treatment significantly increased activity in hibernator muscle. AMPK treatment of hibernator $\mathrm{HK}$ also reduced its $\mathrm{K}_{\mathrm{m}}$ for ATP by about $40 \%$ (Table 2-1). AMPK also shifted the elution pattern of hibernator HK on DEAE ion exchange chromatography which implies that it altered the phosphate 
content of the enzyme. Previous studies have shown that AMPK triggers strong transcriptional up-regulation of HKII in mammalian skeletal muscle (Holmes et al., 1999; Stoppani et al., 2002) and the present data indicate that this protein kinase also has an addition role in directly phosphorylating HKII to change its kinetic properties.

Ground squirrel HK was also responsive to dephosphorylation by protein phosphatases. Incubations that stimulated the actions of total protein phosphatases, serine/threonine protein phosphatases, $\mathrm{PP} 1$, and $\mathrm{PP} 2 \mathrm{~B}$ all resulted in significant reductions in the activity of HK from both euthermic (10-38\% decrease) and hibernating (17-32\% decrease) muscle (Fig. 2-6a). Stimulation of PP1 did not change $\mathrm{HK} \mathrm{K}_{\mathrm{m}}$ values for ATP or glucose (Table 2-1) but did shift the HK elution pattern on DEAE Sephadex. The pattern of response by HK from muscle of hibernating ground squirrels to protein kinases and protein phosphatases, as well as the dual peak elution pattern seen on DEAE, suggests that soluble $\mathrm{HK}$ from hibernator muscle is present as a mixture of high and low phosphate forms. By contrast, the data for soluble euthermic HK which eluted in a single peak (equivalent to peak II hibernator HK) are consistent with an enzyme that is fully phosphorylated (responds just to phosphatases). This conclusion was further supported by the DEAE elution profiles of HKII after incubations that stimulated protein phosphatase type 1 or AMPK action. Stimulation of PP1 activity in muscle extracts from hibernating animals shifted HK activity into Peak I whereas stimulation of AMPK activity in hibernator extracts shifted all HK activity into Peak II. Hence, we conclude that soluble HK in ground squirrels exists in low and high phosphate forms with a mixed population in hibernating muscle and phosphorylated HK only in euthermic muscle. The low phosphate form has a lower substrate apparent affinity for ATP than the high phosphate 
form. HK in hibernator extracts also showed greater stability against urea denaturation. This indicates differential stability of the low and high phosphate forms of $\mathrm{HK}$ and an overall greater stability of the enzyme in extracts from hibernator muscle would be advantageous for maintaining HK over many weeks of cold torpor when protein synthesis is largely shut down. 


\section{Chapter 3}

\section{REGULATION OF SKELETAL MUSCLE CREATINE KINASE FROM A HIBERNATING MAMMAL}




\section{Introduction}

Creatine kinase (CK; EC 2.7.3.2) catalyzes the transfer of a phosphate group from ATP to creatine $(\mathrm{Cr})$ to produce phosphocreatine $(\mathrm{PCr})$ and vice versa. $\mathrm{CK}$ is found in tissues with high and/or fluctuating energy demand like muscle, heart, brain, spermatozoa and photoreceptor cells of the retina (Wallimann et al., 1992). For example, the enzyme constitutes $\sim 20 \%$ of the total soluble protein of skeletal muscle (Lipskaya, 2001). For many years it was believed that the main role of CK was maintenance of energy homeostasis at sites of high ATP turnover. In this function, the $\mathrm{CK} / \mathrm{PCr}$ system acts as a reservoir of high energy phosphate to buffer fluctuations in the intracellular ATP/ADP ratio (McLeish and Kenyon, 2005). Discovery of a mitochondrial CK isoform added the further idea of a $\mathrm{Cr} / \mathrm{PCr}$ shuttle to move high energy phosphate between sites of ATP synthesis (mitochondria) and ATP consumption (e.g. muscle fibrils) (McLeish and Kenyon, 2005).

CK has three organ-specific cytoplasmic isozymes: an MM-CK homodimer in skeletal muscle, a BB-CK homodimer in brain, and a MB-CK heterodimer in heart. In addition, two mitochondrial isozymes exist as octamers: the ubiquitous Miu-CK and the sarcomeric Mis-CK (McLeish and Kenyon, 2005). Changes in the activity of CK can have an effect on available ATP, the energy currency of the cell. Both transcriptional and posttranscriptional mechanisms have been studied as possible mechanis ms for the regulation of CK under energy stress. Ponticos et al (1998) showed that the AMPdependent protein kinase (AMPK) inhibited creatine kinase by protein phosphorylation in vitro and in differentiated muscle cells. However, Ingwall (2002) showed that under low $\mathrm{pO}_{2} \mathrm{CK}$ velocity fell by 2-4 fold whereas the increase in AMPK activity was modest; 
hence, other mechanisms may also be involved. Chida et al (1990a; 1990b) found that inhibition of protein kinase C (PKC) can decrease CK activity. The goal of the present study was to analyze the possible mechanisms of regulation that could be involved in CK control during the phenomenon of mammalian hibernation.

Maintenance of viable cellular energy status during torpor is important. Total adenylate levels in organs typically fall by about one-third during torpor but adenylate energy charge is maintained (MacDonald and Storey, 1999; English and Storey, 2000). Differential regulation of AMP deaminase and adenylate kinase from prairie dog skeletal muscle has been reported with respect to the high and low $\mathrm{Tb}$ values that characterize euthermia versus hibernation (English and Storey, 2000). Specific regulation of other enzymes involved in energy metabolism probably also contributes to the control of cellular energetics during torpor.

The present chapter evaluates skeletal muscle CK from Richardson's ground squirrels, Spermophilus richardsonii, assessing the enzyme in euthermic and hibernating states with respect to protein and mRNA levels, activity and kinetic parameters, reversible phosphorylation, and stability against denaturants to determine how the enzyme is regulated when the animal enters torpor.

\section{Materials and methods}

\section{Animals}

Protocols for care and handling of Richardson's ground squirrels, S. richardsonii, were essentially as reported previously (MacDonald and Storey, 1998; Thatcher and Storey, 2001) and described in greater detail in Chapter 2. 


\section{Preparation of tissue extracts}

Samples of thigh skeletal muscle were homogenized 1:12.5 w:v in $50 \mathrm{mM}$ Tris buffer, pH 8.0 containing $50 \mathrm{mM} \beta$-glycerol phosphate, $2 \mathrm{mM}$ EDTA, 2 mM EGTA and $10 \mathrm{mM} \beta$-mecapthoethanol with a few crystals of the protease inhibitor, phenylmethylsulfonyl fluoride (PMSF) added just prior to homogenization. Homogenates were centrifuged at $25,000 \mathrm{~g}$ for $30 \mathrm{~min}$ and then the supernatant was removed and stored on ice. For kinetic studies, samples of supernatant were diluted 20 times with cold homogenization buffer. To study the kinetic properties of CK bound to the particulate fraction, pellets were re-suspended in homogenization buffer, recentrifuged, and the supernatant was removed. This washing procedure was repeated 3 times to make sure there was no unbound CK left. The final pellet was then resuspended in $2 \mathrm{ml}$ of homogenization buffer and CK properties were assayed using aliquots of the well-mixed suspension. In selected cases, the final pellets were re-suspended in $150 \mathrm{mM} \mathrm{KCl}$ in homogenization buffer in order to release bound CK so that maximal activity could be quantified in bound soluble fractions to determine the percentage of total CK that was bound.

\section{Enzyme assay}

CK activity (creatine + ATP $\rightarrow$ phosphocreatine + ADP) was measured at $340 \mathrm{~nm}$ using a Multiskan Spectrum microplate reader to measure the rate of ADP production in a coupled assay system with pyruvate kinase (PK) and lactate dehydrogenase (LDH). Optimal assay conditions were determined to be $50 \mathrm{mM}$ Tris buffer $\mathrm{pH} 8.4,5 \mathrm{mM}$ 
MgATP, $10 \mathrm{mM}$ creatine, $20 \mathrm{mM} \mathrm{MgCh}, 100 \mathrm{mM} \mathrm{KCl,} 4 \mathrm{mM}$ PEP, $0.225 \mathrm{mM}$ NADH, and $1 \mathrm{U} /$ assay each of $\mathrm{LDH}$ and PK. Routine assays were run at $25^{\circ} \mathrm{C}$ and used $5 \mu 1$ of diluted supernatant. $\mathrm{S}_{0.5}$ values for creatine and MgATP were determined at constant cosubstrate concentrations, $5 \mathrm{mM}$ MgATP or $10 \mathrm{mM}$ creatine. All ATP stock solutions were prepared as a 1:1 molar mix with $\mathrm{MgCb}$.

\section{Incubations to promote protein phosphatase or kinase activities}

Samples of supernatant or pellet extracts were incubated for $4 \mathrm{~h}$ at $25^{\circ} \mathrm{C}$ with inhibitors or stimulators of protein kinases or protein phosphatases as described previously (MacDonald and Storey, 1999) and with greater detail in Chapter 2 of this thesis with following changes. Because $\mathrm{NaF}$ inhibits $\mathrm{CK}$ activity, $50 \mathrm{mM} \beta$-glycerol phosphate was used to inhibit protein phosphatases. Moreover $\mathrm{pH}$ of incubation buffers was 8.4. After incubation, additives were removed by low speed centrifugation of samples through small columns of Sephadex G25 equilibrated in homogenization buffer (50 mM Tris buffer, pH 8.4 containing $50 \mathrm{mM}$ ß-glycerol phosphate, 2 mM EDTA, 2 mM EGTA, 10 mM ß-mecapthoethanol) followed by assay of CK activity under optimal conditions. When bound CK was analyzed samples could not be desalted with G25 columns but instead were centrifuged to pellet the bound CK and myofibrils, then the supernatant was removed, and the pellet was resuspended in homogenization buffer.

To confirm that there was no effect of incubation time or additives on CK in the absence of the protein kinases or protein phosphatases present in the crude extract, we incubated samples of commercial pure rabbit $\mathrm{CK}$ for $4 \mathrm{~h}$ under each of the conditions used above followed by removal of additives by centrifuging through Sephadex G25 and 
assay of CK. CK activity was the same after incubation under every condition.

Furthermore, to confirm that the treatments used to stimulate protein kinases actually resulted in the phosphorylation of $\mathrm{CK}$, incubations were repeated in the presence of 10 $\mu$ Ci radiolabled ? ${ }^{32} \mathrm{P}-\mathrm{ATP}$. After 4 hours of incubation, $60 \mu \mathrm{l}$ of Insoluble Protein A (IPA) (Sigma, P7155) was added to each sample, incubated overnight, and then samples were centrifuged at $12,000 \mathrm{rpm}$; this treatment remove s proteins that bind nonspecifically to IPA. Subsequently, samples were incubated with $1 \mu \mathrm{g}$ of CK-M goat polyclonal IgG (Santa Cruz) for 1 hour and then $60 \mu \mathrm{l}$ IPA was added and incubated overnight to form CK-antibody-IPA complexes. Pellets were then collected by centrifugation at $12,000 \mathrm{rpm}$ followed by washing 7 times with $100 \mu \mathrm{l}$ Tris buffer, $\mathrm{pH}$ 7.5. Aliquots $(10 \mu \mathrm{l})$ of the suspension were spotted on P81 paper and exposed to a phospho rscreen. The radioactivity in each spot was quantified using a Personal Molecular Imager®-FX (BioRad).

\section{Western blotting}

Western blotting was performed as described in Chapter 2 with the following changes. Electrophoresis was carried out at $120 \mathrm{~V}$ for $80 \mathrm{~min}$. Proteins were transferred to polyvinylidene difluoride membrane (PVDF) at $30 \mathrm{~V}$ overnight. Membranes were blocked with 5\% non-fat dried milk in Tris-buffered saline containing the detergent Triton-X (TBST) for 30 min and then washed three times with TBST. Membranes were incubated with primary antibody raised against muscle CK (CK-M goat polyclonal IgG) (Santa Cruz) overnight at $4^{\circ} \mathrm{C}$. After washing with TBST, membranes were incubated with secondary antibody (mouse anti goat IgG) for $4 \mathrm{~h}$ and then washed. 
To determine if the mitochondrial form of $\mathrm{CK}$ was present in the cytoplasmic extracts of ground squirrel muscle, the above procedure was repeated using rabbit polyclonal IgG for creatine kinase MT (Abcam, AB38277) as the primary antibody and goat anti-rabbit IgG (Cell Signaling) as a secondary.

\section{RT-PCR}

To compare the levels of $\mathrm{CK}$ mRNA in muscle of euthermic versus hibernating animals, total RNA was isolated from ground squirrel muscle and cDNA was synthesized and quantified as described previously (Morin and Storey, 2005). Primers for CK were designed using DNAMAN software Version 4 (Lynnon Biosoft) based on the conserved consensus sequence of rat and mouse $m-c k$ and were synthesized by Sigma Genosys. The forward and reverse primer sequences were 5'-CCACTGACAAGCACAAGACT-3' and 5'-CAGGTGCTGGTTCCACATGA-3' respectively. As a control, $\alpha$-tubulin was amplified with forward [5'-TGCTCATCAGTTGCCAA-3'] and reverse [5'GGTCACATTTCACCATCTG-3'] primers. PCR reactions were carried out essentially as in Morin and Storey (2005) with amplification cycles that consisted of an initial step of $2 \mathrm{~min}$ at $94^{\circ} \mathrm{C}$, followed by $94^{\circ} \mathrm{C}$ for $1 \mathrm{~min}, 63^{\circ} \mathrm{C}$ for $1 \mathrm{~min}$ and $72^{\circ} \mathrm{C}$ for $2 \mathrm{~min}$ repeated 37 times with a final step of $72^{\circ} \mathrm{C}$ for $2 \mathrm{~min}$. A $m$-ck fragment of $\sim 500$ base pairs was found after running the PCR products on a $1 \%$ agarose gel.

\section{DEAE ion exchange chromatography}

Ion exchange chromatography was used to separate multiple forms of CK. Muscle extracts were prepared 1:5 w:v in homogenizing buffer (as above). A $200 \mu$ l aliquot of 
crude extract was applied to a DEAE Sephadex G50 column $(1.5 \mathrm{~cm} \mathrm{x} 5 \mathrm{~cm})$ equilibrated in $12.5 \mathrm{mM}$ Tris- $\mathrm{HCl}$ buffer $\mathrm{pH} 8.0,12.5 \mathrm{mM} \beta$-glycerol phosphate and $10 \mathrm{mM} \beta$ mercaptoethanol and then eluted with a linear $\mathrm{KCl}$ gradient $(0-400 \mathrm{mM})$ in the same buffer.

\section{Purification of CK}

For purification of $\mathrm{CK}$, peak fractions from the DEAE Sephadex G50 column described above were pooled and concentrated using a Macrosep $\AA^{\circledR} 10 \mathrm{~K}$ OMEGA with centrifugation in $5400 \mathrm{rpm}$ for $90 \mathrm{~min}$ in a Sorvall RC-B centrifuge with an SS-34 rotor. The concentrated sample was then applied to a Cibacron Blue 3 GA column $(1.5 \mathrm{~cm} \times 5$ $\mathrm{cm}$ ) and eluted under the same conditions as the DEAE column. Peak fractions were pooled and concentrated. The purity of $\mathrm{CK}$ at each step was checked by running samples on SDS-PAGE (as described for Western blotting) with Coomassie blue staining. The purified preparation was stored at $4^{\circ} \mathrm{C}$ where it was stable for 4 days.

\section{Structural and stability studies of creatine kinase}

Intrinsic fluorescence - Aliquots of creatine kinase $(8 \mu \mathrm{g} / \mathrm{ml})$ from rabbit muscle (Sigma catalogue \# C3755) or purified CK from euthermic ground squirrels were incubated for $60 \mathrm{~min}$ in the presence of different concentrations of guanidine hydrochloride or at different temperatures. After incubation, the intrinsic fluorescence was measured by scanning the emission wavelength from $300 \mathrm{~nm}$ through $500 \mathrm{~nm}$ using a Perkin Elmer Luminescence Spectrometer LS 50B (excitation wavelength $285 \mathrm{~nm}$, excitation slit $5 \mathrm{~nm}$, emission slit $5 \mathrm{~nm}$, light path $5 \mathrm{~mm}$ ). 
ANS - Aliquots of purified CK $(0.75 \mu \mathrm{M})$ were incubated with different $\mathrm{GnHCl}$ concentrations (as above) and then $200 \mu \mathrm{M} 8$-anilino-1-naphthalene-sulfonic acid (ANS) was added to each solution and incubated for $30 \mathrm{~min}$. ANS fluorescence was then measured by scanning the emission wavelength from $400-500 \mathrm{~nm}$ (excitation wavelength $390 \mathrm{~nm}$, excitation slit $5 \mathrm{~nm}$, emission slit $5 \mathrm{~nm}$, light path $5 \mathrm{~mm}$ ).

\section{Structural stability of creatine kinase using pulse proteolysis, Pulse} proteolysis was performed as described in Chapter 2. Each sample was then subjected to Western blotting as described above to measure the amount of folded protein remaining. The method was essentially that of Park and Marquesee (2005).

\section{Data, statistics and protein determination}

Data were analyzed as described in Chapter 2.

\section{Results}

\section{Kinetic analysis of ground squirrel muscle CK}

Initial studies of CK from skeletal muscle of Richardson's ground squirrels optimized homogenization conditions for retrieving maximum CK activity. The inclusion of protein kinase inhibitors (EDTA/EGTA) or the protein phosphatase inhibitor ( $($ glycerophosphate) in the homogenization buffer did not affect the measurable amount of $\mathrm{CK}$ but the presence of $\mathrm{NaF}$, another phosphatase inhibitor, reduced the $\mathrm{CK}$ retrieved by $\sim 50 \%$; hence, standard homogenization conditions omitted $\mathrm{NaF}$. Crude preparations of CK prepared as described in the Methods and stored at $5^{\circ} \mathrm{C}$ were stable up to 4 days. The 
$\mathrm{pH}$ optimum of the CK reaction (for the creatine + ATP direction) was determined to be $8.4 \pm 0.01(n=4$ determinations on separate preparations of enzyme). However, the peak was rather broad with $95 \%$ of activity retained at $\mathrm{pH}$ values of 8.2 and 8.8 and $90 \%$ remaining down to $\mathrm{pH}$ 7.8. Free magnesium concentration was also optimized; maximal activity was achieved at $15 \mathrm{mM} \mathrm{MgCh}$ and above and standard assays were run at 20 $\mathrm{mM} \mathrm{MgCl}$ to ensure that free $\mathrm{Mg}^{2+}$ was not limiting in different experimental situations. The maximum activity of CK in soluble extracts of skeletal muscle was $318 \pm 30$ $\mathrm{U} / \mathrm{g}$ wet weight in muscle from euthermic squirrels and $\sim 20 \%$ lower at $257 \pm 25 \mathrm{U} / \mathrm{g}$ wet weight in torpid squirrels ( $\mathrm{n}=7$; significantly different, $\mathrm{P}<0.05$ ). Velocity versus substrate concentration curves for muscle $\mathrm{CK}$ in crude extracts from both euthermic and hibernating ground squirrels are shown in Figure 3-1 and $\mathrm{S}_{0.5}$ values are summarized in Table 3-1. The velocity versus [ATP] relationship was sigmoidal with a low Hill coefficient $\left(n_{H}=1.5\right)$ for euthermic CK but with a much higher value $\left(n_{H}=2.5\right)$ for the hibernator enzyme (Figure 3-1a). The $\mathrm{S}_{0.5}$ ATP was $74 \%$ higher and significantly different $(\mathrm{P}<0.05)$ for the hibernator enzyme, compared with euthermic CK (Table 3-1). Similar results were seen for the velocity versus [creatine] relationship: sigmoidal relationships $\left(n_{\mathrm{H}}=1.6-1.8\right)$ occurred (Figure $\left.3-1 \mathrm{~b}\right)$ and $\mathrm{S}_{0.5}$ creatine was $27 \%$ higher $(\mathrm{P}<0.05)$ for hibernator $\mathrm{CK}$.

Muscle CK is known to bind to myosin and a portion of total CK remains in the pellet under normal homogenization and centrifugation conditions. Re-extraction of the pellet was used to remove any unbound CK and then bound CK was characterized in resuspended pellets. $S_{0.5}$ creatine of bound CK from euthermic animals was $25 \%$ lower (ie. substrate apparent affinity was higher) $(\mathrm{P}<0.05)$ as compared with soluble CK but $\mathrm{S}_{0.5}$ 
ATP was unaffected (Table 3-1, Figure 3-1). To determine the percentage of CK that was bound in pellets, final pellets were in some cases re-suspended in $150 \mathrm{mM} \mathrm{KCl}$ to disrupt binding and then free CK activity was measured in this fraction Total CK was then calculated as the sum of soluble $+\mathrm{KCl}$ released $\mathrm{CK}$ and the percentage that was present in the pellet was determined to be $20.4 \pm 0.2 \%$ in extracts of euthermic muscle and was not significantly different $(25.3 \pm 0.9 \%)$ in hibernator extracts.

\section{Temperature effects on CK}

Arrhenius plots showing the effect of temperature on CK activity are shown in Figure 3-2. The relationship was linear over the full range of temperatures tested (2$35^{\circ} \mathrm{C}$ ). Calculated activation energy, Ea, for $\mathrm{CK}$ from euthermic ground squirrels was $57.1 \pm 2.2 \mathrm{~kJ} / \mathrm{mol}$ and $28 \%$ higher $(\mathrm{P}<0.05)$ at $73.3 \pm 2.3 \mathrm{~kJ} / \mathrm{mol}$ for $\mathrm{CK}$ hibernating animals. By comparison, the Ea of purified rabbit CK was $68.7 \pm 1.5 \mathrm{~kJ} / \mathrm{mol}$.

Figure 3-3 shows the effect of temperature on the $\mathrm{S}_{0.5}$ values for ATP and creatine. $\mathrm{S}_{0.5}$ values for both substrates generally increased with increasing temperature between 5 and $30^{\circ} \mathrm{C}$ for creatine (by $\sim 2.5$ fold) (Figure 3-3b) and between 5 and $20-25^{\circ} \mathrm{C}$ for ATP (by $\sim 2-2.5$ fold) (Figure 3-3a). $\mathrm{S}_{0.5}$ ATP for euthermic CK peaked at $20^{\circ} \mathrm{C}$ and declined at higher temperatures whereas $\mathrm{S}_{0.5}$ ATP of hibernator CK peaked at $25^{\circ} \mathrm{C} . \mathrm{S}_{0.5}$ ATP values were significantly different $(\mathrm{P}<0.05)$ between euthermic and hibernating states at both 25 and $30^{\circ} \mathrm{C}$. CK from rabbit muscle showed a different pattern of change in $\mathrm{S}_{0.5}$ ATP with highest $\mathrm{S}_{0.5}$ values $(\sim 0.8 \mathrm{mM})$ at 5 and $30^{\circ} \mathrm{C}$ and a minimum value of $0.38 \mathrm{mM}$ (highest apparent affinity) at $15^{\circ} \mathrm{C}$ (Figure $\left.3-3 \mathrm{a}\right)$. 


\section{Reversible phosphorylation of CK}

Stable kinetic differences in the properties of an enzyme between two states are often the result of state-dependent reversible phosphorylation catalyzed by protein kinases and protein phosphatases. To determine if this mechanism was responsible for the differences in CK properties between euthermic and hibernating states described above, tissue extracts were incubated under conditions that stimulated the actions of endogenous protein phosphatases or kinases and the resulting effects on CK activity were measured. Initial trials using purified rabbit $\mathrm{CK}$ incubated for $4 \mathrm{~h}$ under each of the conditions used, followed by desalting through Sephadex G25 and assay showed that the incubation conditions themselves (in the absence of protein kinases and phosphatases) had no effect on CK. Figure 3-4a shows the effect of incubating CK under conditions that promoted protein phosphatase action. Note that in the control (no additions) condition, CK activity was 1.76-fold higher $(\mathrm{P}<0.05)$ in muscle extracts from euthermic versus hibernating squirrels. This is greater than the $20 \%$ higher CK activity in euthermia reported above for activities measured per gram wet weight, the difference being due to a change in the total soluble protein content of extracts from hibernator muscle compared with euthermic muscle. Incubations that facilitated protein phosphatase action generally increased the activity of $\mathrm{CK}$ in extracts from both euthermic and hibernating animals. For $\mathrm{CK}$ in euthermic extracts, the increase was $16-30 \%(P<0.05)$ after incubation under conditions that promoted total protein phosphatases or (in the presence of specific inhibitors) selectively facilitated serine/threonine phosphatases, PP1 or PP2B and alkaline phosphatase (Figure 3-4a) whereas conditions that facilitated PP2C did not affect CK activity. Extracts from hibernating muscle incubated under the same conditions also 
showed elevated CK activity, $12-39 \%$ increases $(\mathrm{P}<0.05)$, in all cases except under conditions that promoted PP2C.

By contrast, incubation of euthermic extracts under conditions that stimulated the activities of endogenous protein kinases generally produced a significant decrease $(\mathrm{P}<0.05)$ in CK activity. Activities were reduced by $28.8,10.7$ and $21.4 \%$, as compared with the control, after stimulation of PKA, PKC and PKG activities, respectively. However, stimulation of AMPK did not affect CK activity from euthermic ground squirrels. Stimulation of protein kinase activities did not significantly affect CK activity in hibernator extracts under any conditions.

Incubations that facilitated protein kinase or phosphatase action on CK also resulted in altered enzyme apparent affinity for ATP, but not creatine (Table 3-1). Stimulation of PKA in muscle extracts from euthermic animals significantly increased the $\mathrm{S}_{0.5}$ ATP by 1.6-fold. By contrast, total protein phosphatase effects on CK in extracts from hibernating animals resulted in a significant $30 \%$ decrease in $\mathrm{S}_{0.5}$ ATP compared with CK in untreated hibernator extracts.

To confirm that the incubations that stimulated protein kinases actually resulted in the phosphorylation of $\mathrm{CK}$, incubations of both euthermic and hibernating $\mathrm{CK}$ were repeated in the presence of ? ${ }^{32} \mathrm{P}-\mathrm{ATP}$ and then the technique of immunoprecipitation was used to selectively pellet CK. These studies showed that incubations that stimulated PKA, PKC, PKG and AMPK all resulted in high levels of ${ }^{32} \mathrm{P}$ labeling of the precipitated CKantibody-IPA complex. Relative to the control incubation without added stimulators of protein kinases, the mean increases in ${ }^{32} \mathrm{P}$ labeling of $\mathrm{CK}$ were 4.2 fold in incubations that stimulated PKA activity, and 3.3, 3.7 and 3.8 fold in incubations that stimulated PKC, 
PKG and AMPK, respectively

The effects of incubations under conditions that facilitated protein kinase or phosphatase action were also assessed for $\mathrm{CK}$ in the myosin bound fraction. In control incubations when bound $\mathrm{CK}$ activity was measured in resuspended pellets, the relative amount of $\mathrm{CK}$ activity measured in the bound fraction was about 2-fold higher in extracts from hibernating versus euthermic animals (Figure 3-5). Incubation of euthermic CK from the bound fraction under conditions that promoted phosphatase action resulted in a strong increase in CK activity under all conditions (except for PP2C); compared with controls, activity increased by $2.9,2.1,1.7$ and 2.4 -fold in incubations that promoted total phosphatases, Ser/Thr phosphatases, PP1 and PP2B, respectively (Figure 3-5a). However, CK activity from the bound fraction of hibernator muscle was not affected by phosphatase treatment. The opposite response was seen after incubations that stimulated protein kinases. CK activity from the bound fraction of euthermic muscle was not affected by stimulation of protein kinases. However, activity in the bound fraction from hibernator muscle was strongly reduced after protein kinase treatment; activity was reduced to 39,40 , and $44 \%$ of the control value after incubation under conditions that stimulated PKA, PKC and PKG, respectively (Figure 3-5b). Stimulation of AMPK did not affect bound CK activity.

High and low phosphate forms of enzymes can frequently be separated by ion exchange chromatography because phosphorylation alters the net charge on the enzyme. Figure 3-6 shows the elution patterns of CK activity from DEAE-Sephadex 50 using a 0$400 \mathrm{mM} \mathrm{KCl}$ gradient and comparing the enzyme from euthermic and hibernating Richardson's ground squirrels. Euthermic CK eluted in two peaks (I and II) with the 
majority of activity (75.6\%) in peak II eluting at the higher $\mathrm{KCl}$ concentration $(120 \mathrm{mM}$ $\mathrm{KCl}$ ). When euthermic $\mathrm{CK}$ was treated with PKA, peak I disappeared and all activity shifted into peak II. CK in hibernator extracts eluted in a single peak at the same $\mathrm{KCl}$ concentration as peak II of euthermic CK. When hibernator $\mathrm{CK}$ was incubated under conditions that promoted total protein phosphatase activity the peak shifted to elute at a lower $\mathrm{KCl}$ concentration $(75 \mathrm{mM} \mathrm{KCl})$, equivalent to peak $\mathrm{I}$ in euthermic extracts. The data are consistent with peak I being the low phosphate (dephosphorylated) form of CK whereas peak II is the high phosphate (phosphorylated) enzyme form. Furthermore, $\mathbf{S}_{0.5}$ values for peak I and II CK were the same as the values given in Table 3-1 for hibernating CK after PPase treatment versus untreated hibernating CK, respectively.

The above information strongly indicates that the two peaks represent different phosphorylation states of $\mathrm{CK}$, but to confirm that the peaks were not different isozyme forms, we used Western blotting to assess the relative content of the cytoplasmic CK-M form and the mitochondrial CK-MT form in muscle extracts. Western blotting using antibodies raised against $\mathrm{CK}-\mathrm{M}$ detected a single very strong band at $43 \mathrm{kDa}$, the known subunit size of the mammalian CK-M, in all samples. However, no bands were detected in the 47-51 kDa region (the subunit size of mammalian CK-MT) when blots were exposed to antibodies for CK-MT. This indicates that CK-MT was either pelleted in the preparation of muscle cytoplasmic extracts or present in levels too low to detect under the conditions used. Hence, this provided added evidence that the peaks of CK activity seen in Figure 3-6 are CK-M. 


\section{CK protein and mRNA levels}

Figure 3-7 shows the relative levels of CK protein and CK mRNA, as determined by Western blotting and RT-PCR, respectively, as well as CK activity in skeletal muscle of euthermic and hibernating Richardson's ground squirrels. All three parameters were significantly reduced during hibernation $(\mathrm{P}<0.05)$. $\mathrm{CK}-\mathrm{M}$ protein content in muscle was reduced by $20 \%$, as was $\mathrm{CK}$ activity, whereas CK mRNA levels were very strongly suppressed by $70 \%$.

\section{Purification of CK}

Table 3-2 shows a purification scheme for CK from skeletal muscle of euthermic ground squirrels. Using a combination of DEAE ion exchange chromatography and Cibacron Blue 3GA chromatography, the enzyme was purified $\sim 20$-fold with an overall yield of $56 \%$. The final specific activity of enzyme was $41.9 \mathrm{U} / \mathrm{mg}$ protein. Purity of the enzyme was confirmed via SDS-polyacrylamide gel electrophoresis with Coomassie blue staining (Figure 3-8) which showed a single band after the Cibacron Blue step indicating that the enzyme was purified to homogeneity. The purity of the enzyme was also confirmed when silver staining was used. The CK band had a molecular weight of $\sim 48$ $\mathrm{kD}$ which corresponds with the subunit size of commercial rabbit M-CK run under the same conditions (not shown).

\section{Structural stability of CK}

Unlike enzymes from most mammalian species, enzymes in hibernator tissues have to function at both high $\left(37^{\circ} \mathrm{C}\right)$ and low (near $\left.0^{\circ} \mathrm{C}\right)$ body temperatures and because 
of this they may exhibit modifications of their protein structure that alter/maintain structural stability. To compare the structural stability of muscle CK from a hibernator (ground squirrel) versus a nonhibernator (rabbit), three methods were used: (a) analysis of changes in tryptophan fluorescence with respect to incubation temperature or guanidine hydrochloride concentration, (b) monitoring the fluorescence of \&anilino-1naphthalene-sulfonic acid (ANS) a function of guanidine hydrochloride concentration, or (c) analyzing CK sensitivity to thermolysin proteolysis as a function of the concentration of the denaturant, urea.

Stability studies were carried out first on commercial rabbit muscle CK (Figure 39). The effects of temperature on tryptophan fluorescence intensity and emission maximum are shown in Figure 3-9a,b. Relative fluorescence intensity at $340 \mathrm{~nm}$ began to decline at temperatures above $40^{\circ} \mathrm{C}$ and fell progressively by more than $50 \%$ by $70^{\circ} \mathrm{C}$; the $\mathrm{T}_{1 / 2}$ for protein unfolding was $50^{\circ} \mathrm{C}$ (Figure 3-9a). Over a narrower temperature range between 40 and $50^{\circ} \mathrm{C}$, the maximum emission wavelength of $\mathrm{CK}$ rose by about $6 \mathrm{~nm}\left(\mathrm{~T}_{1 / 2}\right.$ $\left.=45^{\circ} \mathrm{C}\right)($ Figure 3-9b). Parallel studies analyzed the effects of a chemical denaturant, guanidine hydrochloride $(\mathrm{GnHCl})$, on tryptophan fluorescence parameters of rabbit $\mathrm{CK}$. $\mathrm{GnHCl}$ causes unfolding of enzyme 3D structure and Figure. 3-9c shows that $\mathrm{GnHCl}$ treatment caused an $\sim 13 \mathrm{~nm}$ increase in the emission maximum of the enzyme. Furthermore, $\mathrm{GnHCl}$ induced unfolding of $\mathrm{M}-\mathrm{CK}$ showed a biphasic profile, suggesting that the transition from the native to fully unfolded protein involves a stable intermediate species. Transition from the native to the intermediate species was completed at $1 \mathrm{M}$ $\mathrm{GnHCl}$ with an increase in the emission maximum to $347 \mathrm{~nm}$. The second phase transition from the intermediate to completely unfolded state occurred by $2 \mathrm{M} \mathrm{GnHCl}$ 
and resulted in a further red shift of the emission maximum to $354 \mathrm{~nm}$. However, although structural changes continued up to $2 \mathrm{M}$, rabbit CK lost its enzymatic activity at a very much lower $\mathrm{GnHCl}$ concentration, the calculated $\mathrm{I}_{50}$ value being just $0.25 \mathrm{M}$.

ANS binding to proteins and monitoring of its fluorescence changes provides a more sensitive way of analyzing denaturant effects on proteins. ANS is a fluorescent probe specific for the hydrophobic regions of a protein. During the denaturation of a protein the hydrophobic parts that are buried inside the protein become more exposed. Interaction of ANS with these solvent-exposed hydrophobic areas of the protein changes its fluorescence and decreases its emission wavelength. With this method the hydrophobicity of the protein can be monitored during denaturation. Rabbit CK was incubated with different concentrations of $\mathrm{GnHCl}$ followed by addition of ANS and monitoring of ANS emission maximum (Figure 3-9e) and corresponding relative fluorescence at the emission maximum at each $\mathrm{GnHCl}$ concentration (Figure 3-9f). The emission maximum of ANS-CK declined from $498 \mathrm{~nm}$ without $\mathrm{GnHCl}$ to $\sim 460 \mathrm{~nm}$ at $\mathrm{GnHCl}$ concentrations of $2.5 \mathrm{M}$ and above; the calculated $[\mathrm{GnHCl}]_{1 / 2}$ was $0.6 \mathrm{M}$ (Figure 3-9e). Figure 3-9f shows that during the transition from the native to the intermediate form there was an increase in fluorescence intensity of ANS-CK (at $1 \mathrm{M} \mathrm{GnHCl}$ ). However, transition from the intermediate species to the completely unfolded protein reversed this effect and fluorescence enha ncement declined with further increases in [GnHC1].

Figure 3-10 shows the comparable patterns of response to chemical denaturants by purified CK from euthermic ground squirrels. Again, in the presence of increasing concentrations of $\mathrm{GnHCl}$, the emission maximum for tryptophan fluorescence rose from 
$340 \mathrm{~nm}$ in the absence of $\mathrm{GnHCl}$ to $356 \mathrm{~nm}$ for completely unfolded enzyme (Figure 310a). GnHClinduced unfolding of M-CK also showed a biphasic profile like rabbit CK. The intermediate $\mathrm{CK}$ species was produced at $1.5 \mathrm{M} \mathrm{GnHCl}$ and was stable up to $2.5 \mathrm{M}$ $\mathrm{GnHCl}$ (maximum emission $352 \mathrm{~nm}$ ). Maximum emission of the completely unfolded CK was $355 \mathrm{~nm}(3 \mathrm{M} \mathrm{GnHCl})$. $\mathrm{CK}$ activity was again very sensitive to $\mathrm{GnHCl}$ with an I50 value of $0.25 \mathrm{M}$ (Figure $3-10 \mathrm{~b}$ ).

The effect of urea on CK unfolding was assessed using the pulse proteolysis method. Urea-induced unfolding makes the enzyme more sensitive to thermolysin proteolysis and hence the amount of CK protein detected on Western blots at the $42 \mathrm{kD}$ subunit size declines when proteolysis occurs. Figure 3-10c shows that rabbit CK was structurally stable up to urea concentrations of $\sim 5 \mathrm{M}$ but the amount of $\mathrm{CK}$ protein detected after thermolysin treatment decreased rapidly at higher urea values; the calculated urea concentration for loss of half of the protein, $[\text { Urea }]_{1 / 2}$, was $5.8 \mathrm{M}$. Ground squirrel CK showed greater sensitivity to urea. Enzyme structure was only stable up to urea concentrations of $3 \mathrm{M}$ for euthermic and $4 \mathrm{M}$ for hibernator $\mathrm{CK}$ but declined rapidly at higher urea levels; the $[\text { Urea }]_{1 / 2}$ was $4.19 \pm 0.02 \mathrm{M}$ for euthermic and $4.39 \pm 0.08 \mathrm{M}$ for hibernator CK (the values were not significantly different). 
Table 3-1. $\mathrm{S}_{0.5}$ values for substrates of skeletal muscle CK from euthermic and hibernating ground squirrels. Conditions are crude CK from euthermic and hibernating animals, myosin-bound CK extracted from euthermic animals, crude euthermic CK incubated under conditions that stimulated protein kinase A (PKA), and crude hibernating CK incubated under conditions that promoted total protein phosphatase action. Assays were conducted at $25^{\circ} \mathrm{C}$ and enzyme parameters were determined using an enzyme kinetics package that fitted data to the Hill equation [19]. Values shown are means $\pm \mathrm{SD}$, $\mathrm{n}=6$ independent determinations on separate preparations of enzyme. ${ }^{\mathrm{a}}$ - Significantly different from the corresponding untreated euthermic value as determined by the Student's t-test, $\mathrm{P}<0.05 \mathrm{~F}^{\mathrm{b}}$ - significantly different from the corresponding untreated hibernating value, $\mathrm{P}<0.05$.

\begin{tabular}{|l|l|l|l|l|}
\hline & $\mathrm{S}_{0.5}$ ATP $(\mathrm{mM})$ & Hill & $\mathrm{S}_{0.5}$ Creatine & Hill \\
& & coefficient & $(\mathrm{mM})$ & coefficient \\
\hline Euthermic & $0.68 \pm 0.006$ & $1.49 \pm 0.14$ & $1.62 \pm 0.11$ & $1.83 \pm 0.03$ \\
\hline Hibernating & $1.18 \pm 0.1^{\mathrm{a}}$ & $2.49 \pm 0.09^{\mathrm{a}}$ & $2.06 \pm 0.16^{\mathrm{a}}$ & $1.64 \pm 0.17$ \\
\hline Myosin bound CK & $0.79 \pm 0.12^{-}$ & $1.60 \pm 0.05$ & $1.2 \pm 0.09^{\mathrm{a}}$ & $1.48 \pm 0.12^{\mathrm{a}}$ \\
\hline Euthermic, PKA- & $1.09 \pm 0.09^{\mathrm{a}}$ & $1.89 \pm 0.08^{\mathrm{a}}$ & $1.71 \pm 0.19$ & $1.65 \pm 0.13$ \\
treated (= peak II) & & & & \\
\hline $\begin{array}{l}\text { Hibernating, PPase- } \\
\text { treated (= peak I) }\end{array}$ & $0.83 \pm 0.007^{\mathrm{b}}$ & $1.56 \pm 0.12^{\mathrm{b}}$ & $1.78 \pm 0.21^{\mathrm{b}}$ & $1.52 \pm 0.06$ \\
\hline
\end{tabular}


Table 3-2. Purification of CK from skeletal muscle of euthermic ground squirrels

\begin{tabular}{llllll}
\hline Purification Step & Total & Total & Specific & Fold & Yield (\%) \\
& Protein & Activity & Activity & purification & \\
& $(\mathrm{mg})$ & $(\mathrm{U})$ & $(\mathrm{U} / \mathrm{mg})$ & & \\
\hline Supernatant & 0.55 & 1.99 & 2.06 & 1 & 100 \\
DEAE Sephadex & 0.21 & 1.74 & 8.34 & 4.05 & 87.3 \\
Cibacron Blue 3GA & 0.03 & 1.12 & 41.9 & 20.3 & 55.9 \\
\hline
\end{tabular}


Figure 3-1. Activity versus substrate concentration relationships for ground squirrel muscle CK. Shown are data for free CK in crude extracts from euthermic (diamonds) and hibernating (squares) animals and bound $\mathrm{CK}$ in euthermic muscle (triangles). A: Effect of variation in ATP concentrations. B: Effect of variation in creatine concentration. $\mathrm{C}$ : Effect of incubating euthermic CK under conditions that stimulate protein kinase or hibernating CK under conditions that promote protein phosphatase action on CK activity versus $[\mathrm{ATP}]$. Data are units $/ \mathrm{mg}$ protein, mean $\pm \mathrm{SEM}, \mathrm{n}=5$ independent determinations on different preparations of enzyme. 
Figure 3-1.
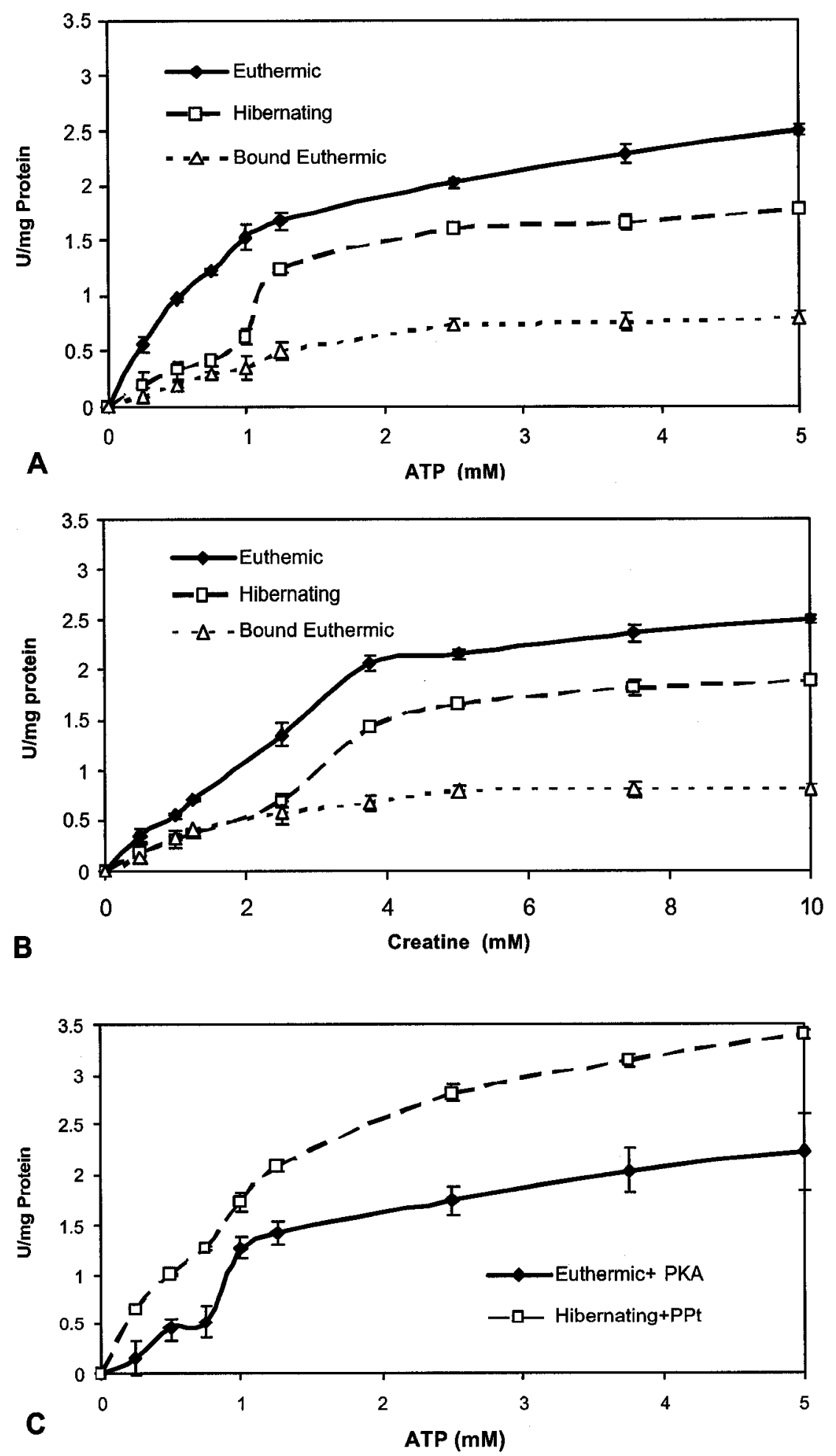
Figure 3-2. Arrhenius plots for skeletal muscle CK. Plots for skeletal muscle CK from euthermic and hibernating ground squirrels are compared with commercial rabbit muscle CK. Data are means $\pm S E M, n=5$ independent determinations on different preparations of enzyme. 


\section{Figure 3-2}

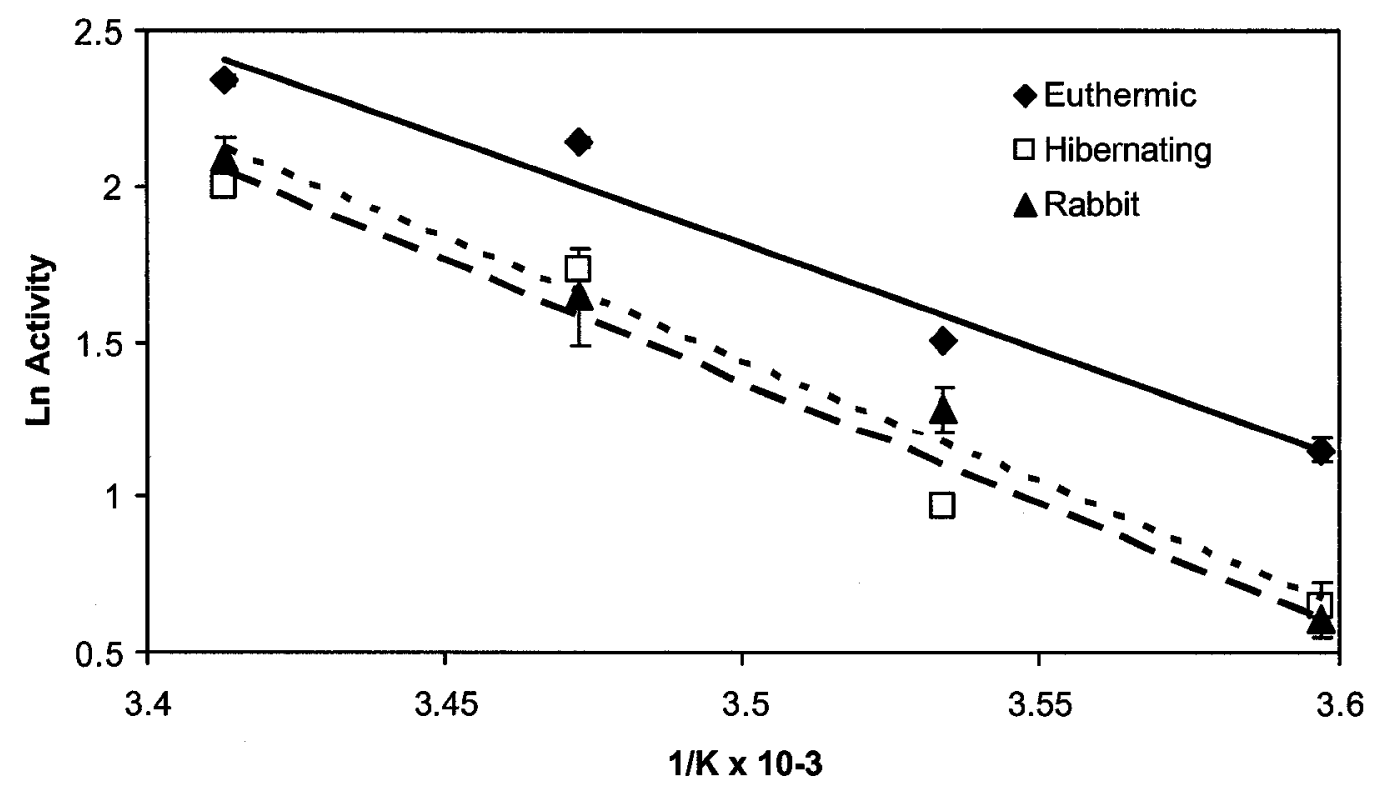


Figure 3-3. $\mathrm{S}_{0.5}$ values for skeletal muscle $\mathrm{CK}$ at different temperatures. $\mathrm{A}: \mathrm{S}_{0.5}$ ATP for CK from euthermic and hibernating ground squirrels and commercial rabbit $\mathrm{CK}$. B: $\mathrm{S}_{0.5}$ creatine for CK from euthermic and hibernating animals. Data are means $\pm S E M, n=4$ independent determinations on different preparations of enzyme. 
Figure 3-3.
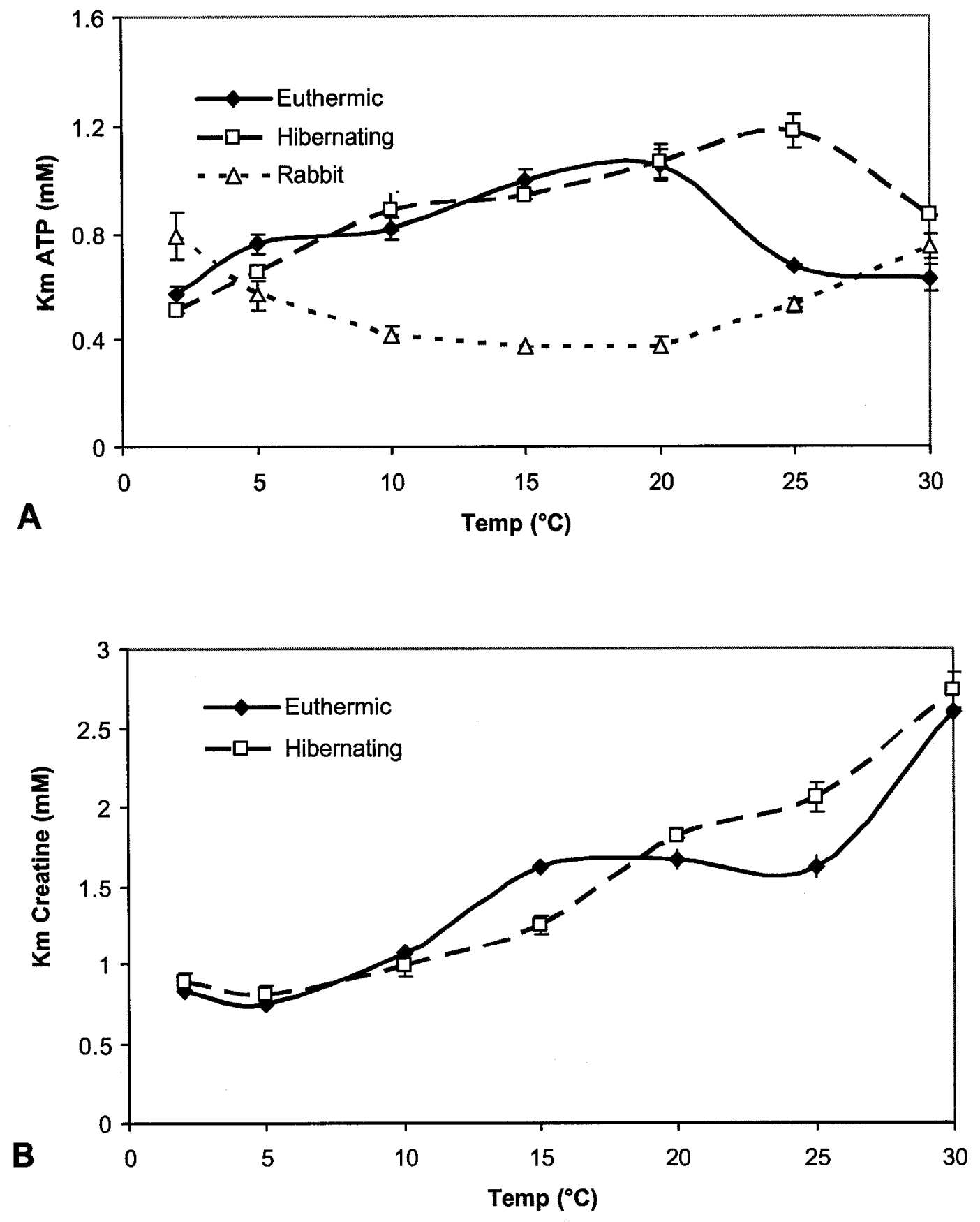
Figure 3-4. Effect of in vitro incubations promoting the action of protein phosphatases or protein kinases on CK activity in soluble extracts of ground squirrel skeletal muscle. A: Incubations that promote endogenous protein phosphatase activities including total protein phosphatases (PPt), Ser/Thr PPs, PP1, PP2B, PP2C and alkaline phosphatase (AP). B: Incubations that stimulate endogenous protein kinases including PKA, PKC, PKG or AMPK. Enzyme extracts were incubated for $4 \mathrm{~h}$ at $25^{\circ} \mathrm{C} \mathrm{h}$ under conditions outlined in the Methods, followed by desalting and assay. Data are means \pm SEM, $n=6$ independent determinations on different preparations of enzyme. * - Significantly different from the corresponding euthermic control (no additions) activity using analysis of variance followed by the Dunnett's test, $\mathrm{P}<0.05 ;+$ - significantly different from the corresponding hibernating control, $\mathrm{P}<0.05$. 
Figure 3-4.
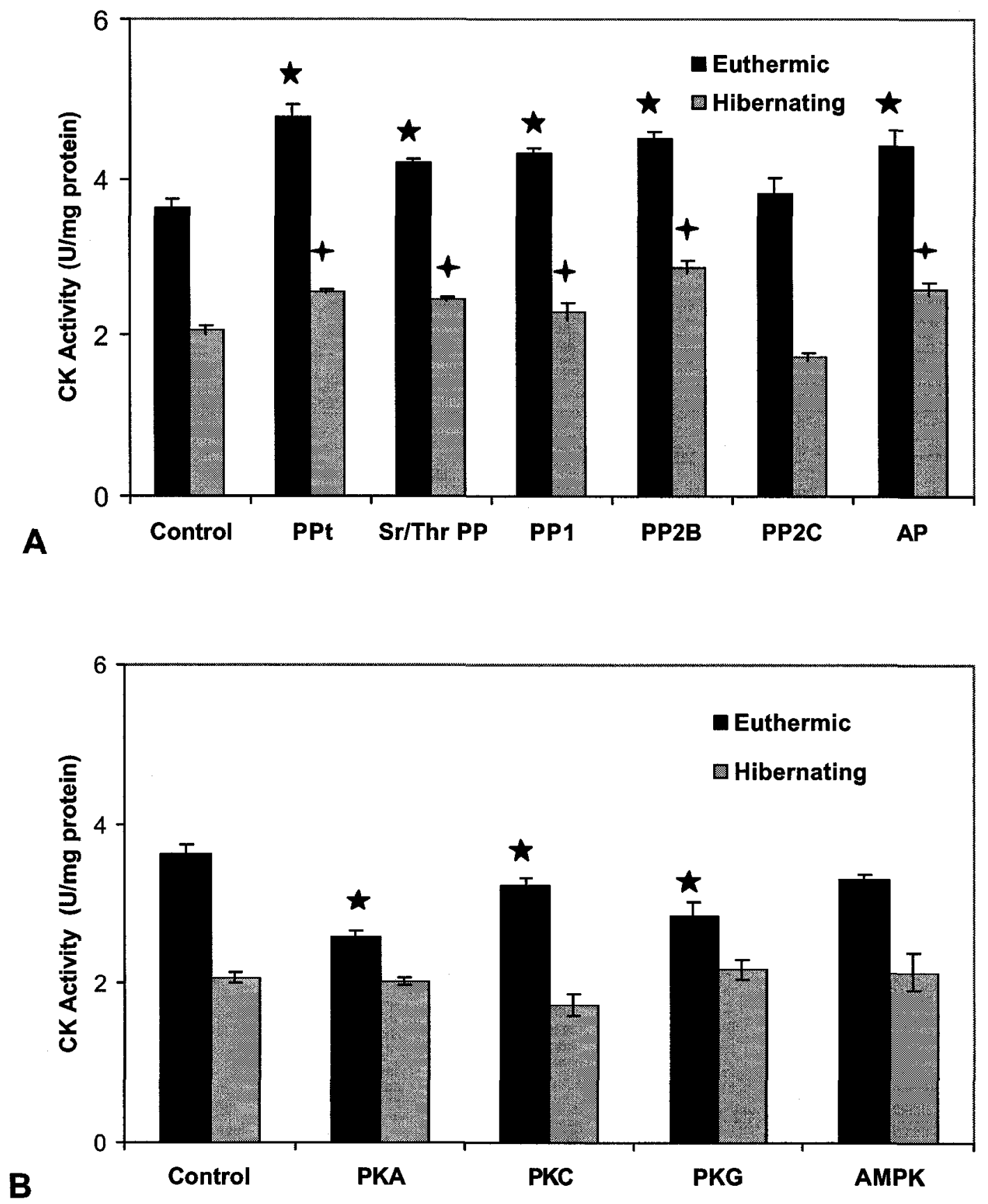
Figure 3-5. Effect of in vitro incubations promoting the action of protein phosphatases or protein kinases on myosin-bound CK activity from ground squirrel muscle. Bound CK was extracted from pellets as described in the Methods and then resuspended in the appropriate buffer. A: Conditions promoting total protein phosphatases (PPt), Ser/Thr PPs, PP1, PP2B or PP2C. B: Stimulation of endogenous protein kinases: PKA, PKC, PKG or AMPK. Other information as in Figure 4. 
Figure 3-5.
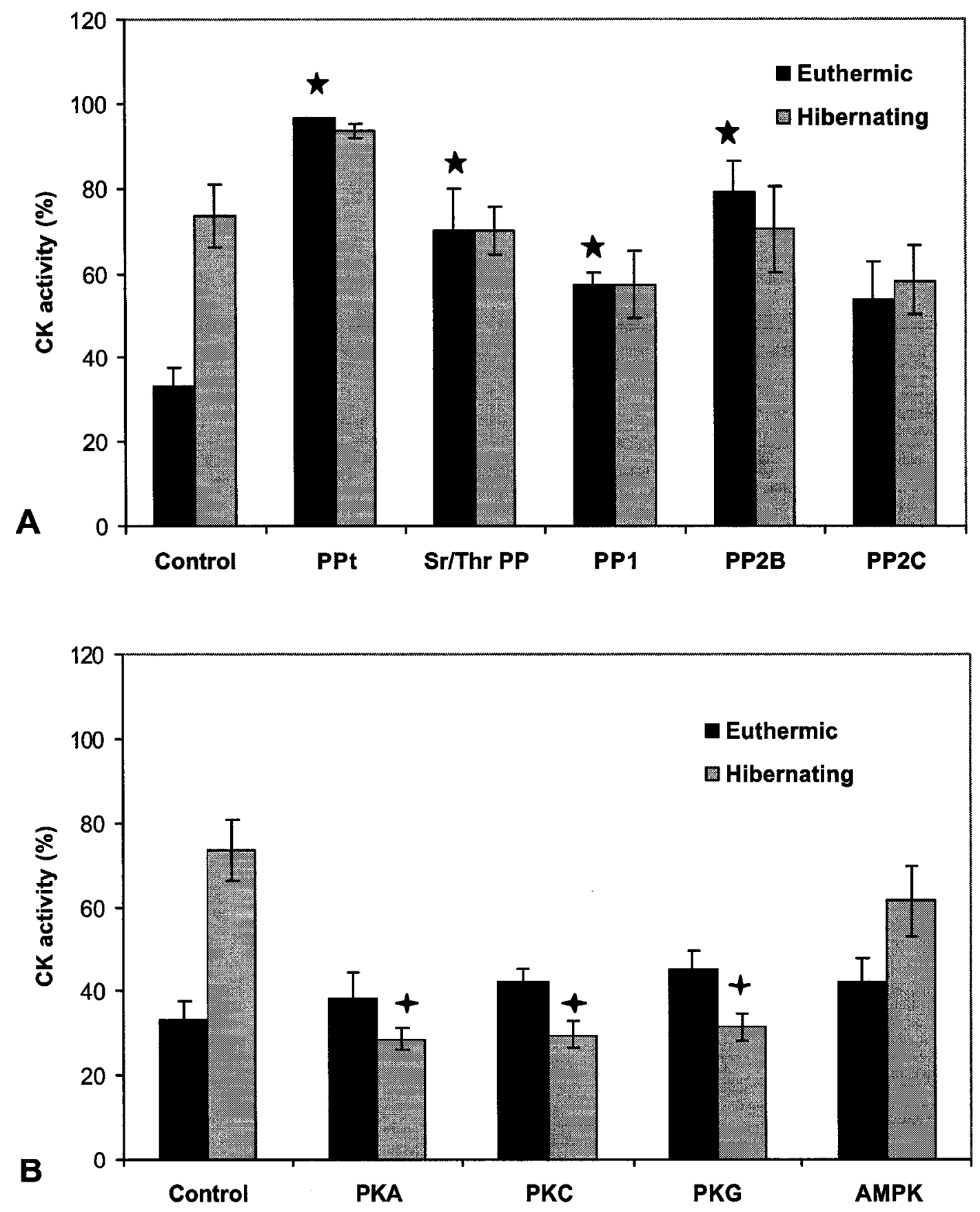
Figure 3-6. DEAE Sephadex ion exchange chromatography of ground squirrel skeletal muscle $\mathrm{CK}$. The column was developed using a $0-400 \mathrm{mM} \mathrm{KCl}$ gradient in buffer, as described in the Methods. A: Elution profile of CK in extracts from euthermic animals before and after incubation under conditions that stimulated PKA action. B: Elution profile of $\mathrm{CK}$ in extracts from hibernating animals before and after treatment to promote the action of total protein phosphatases (PPT). The dotted line shows the salt gradient. Data show representative profiles for single preparations but the same separations were achieved in multiple $(\mathrm{n}=3)$ trials. 
Figure 3-6.

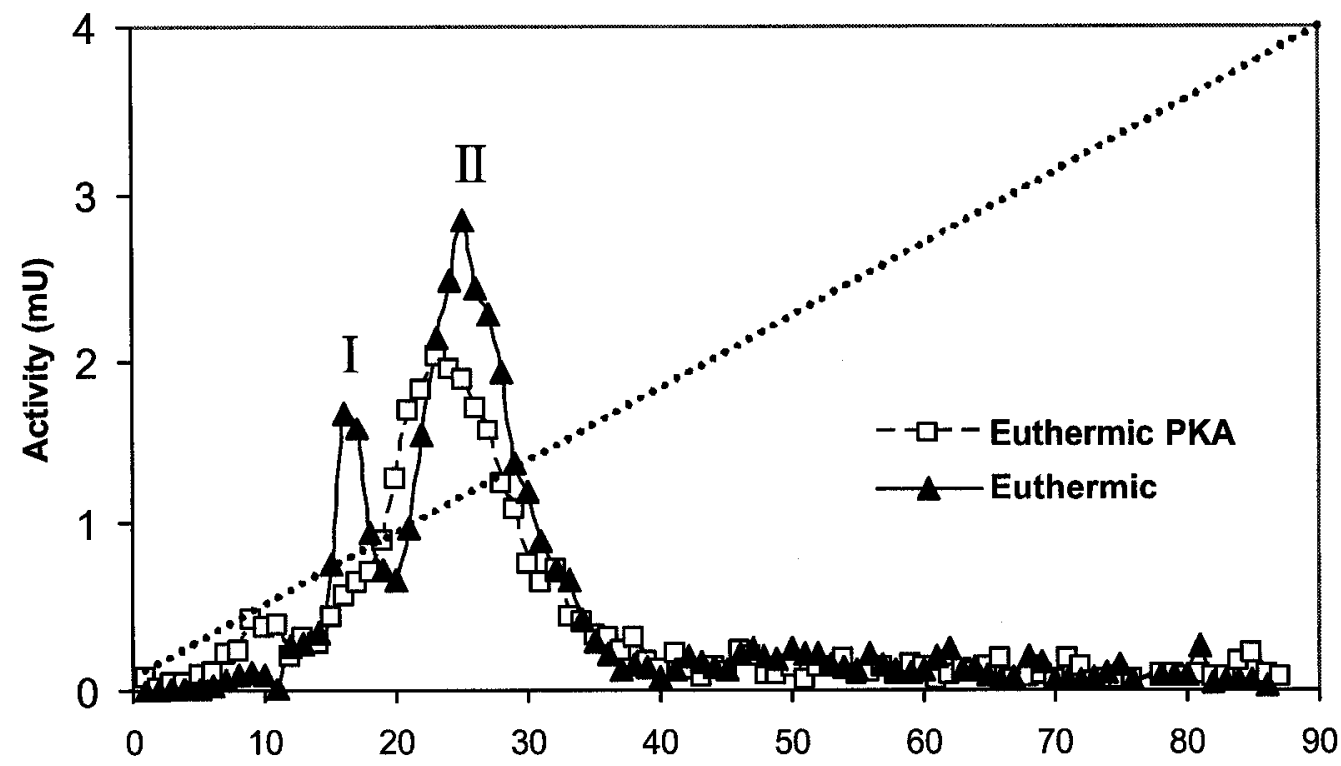

A

Fraction number

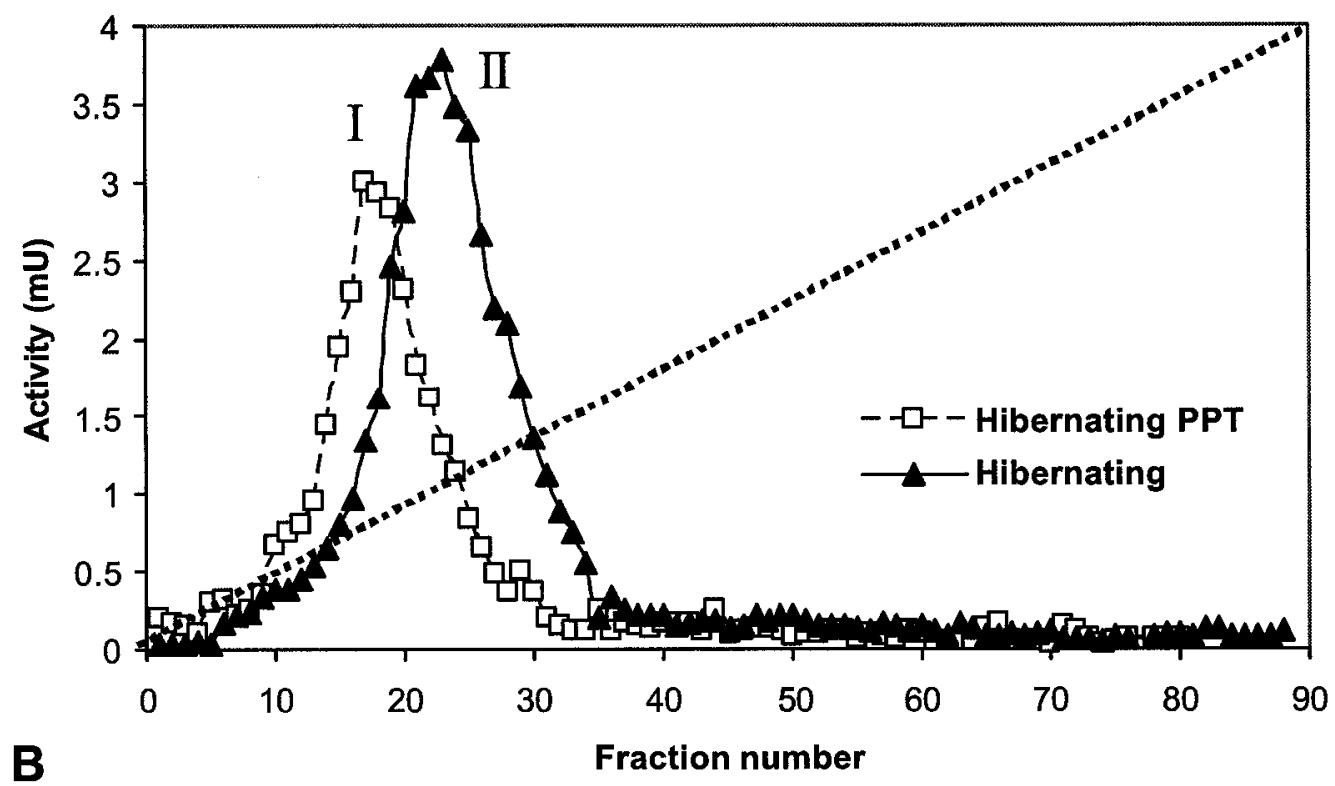


Figure 3-7. Relative $\mathrm{CK}$ protein content, $\mathrm{CK}$ mRNA transcript levels and $\mathrm{CK}$ maximal activity in skeletal muscle of euthermic versus hibernating ground squirrels. Data for hibernating samples are expressed euthermic values which are set to 1.0. Protein was assessed by Western blotting using antibodies recognizing the mammalian muscle isozyme of CK whereas mRNA transcript levels were determined by RT-PCR using primers designed for mammalian muscle $C K$. Data are means $\pm S E M, n=5$ independent determinations. * - Significantly different from the corresponding euthermic value, $\mathrm{P}<0.05$. 
Figure 3-7.
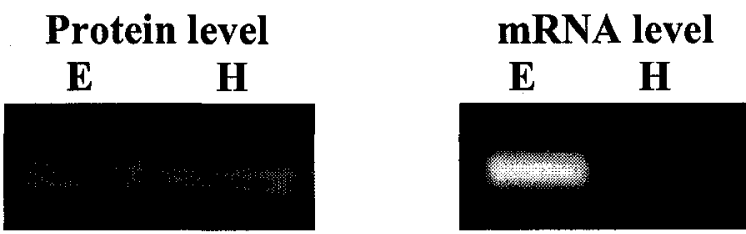

E: Euthermic

H: Hibernating

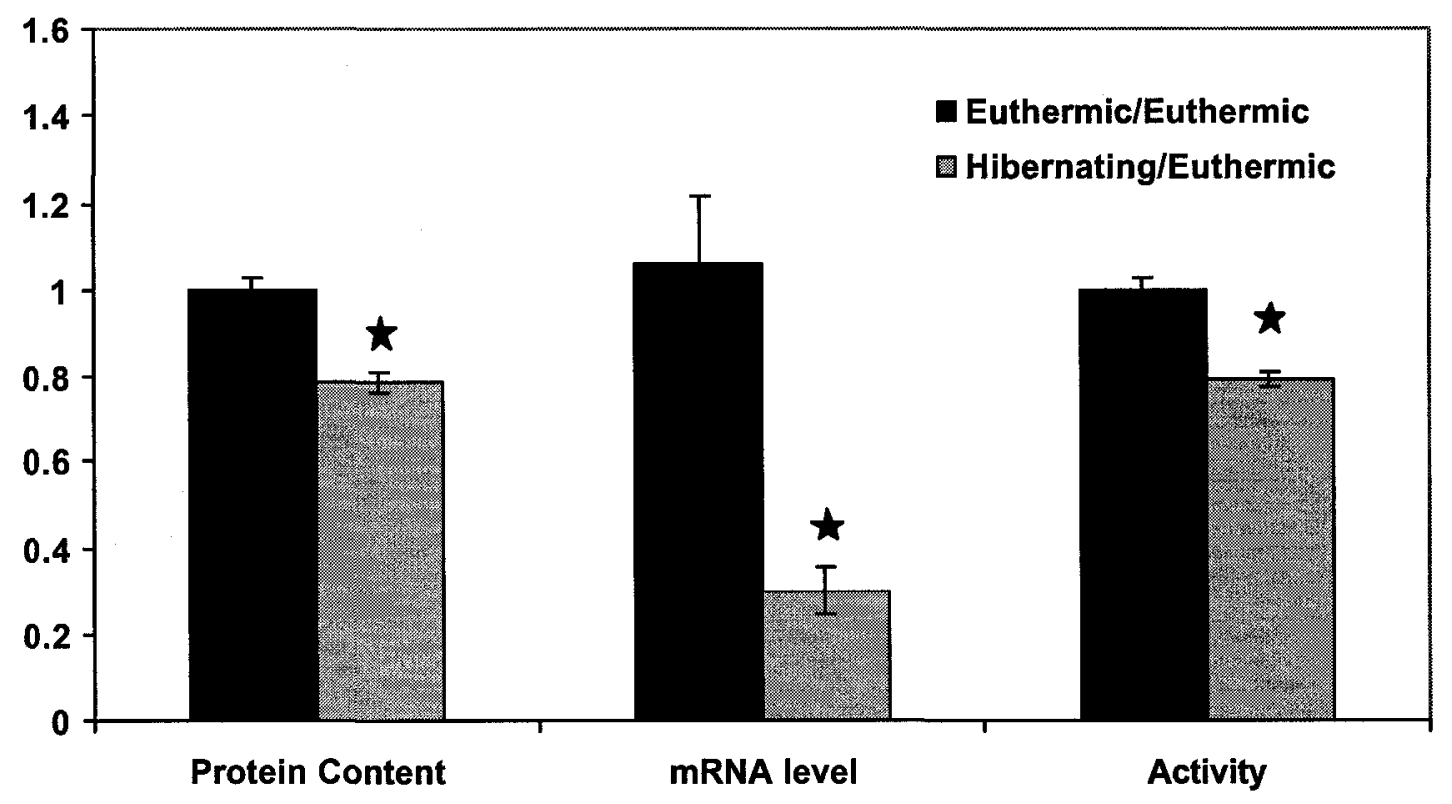


Figure 3-8. SDS-PAGE gel (10\% acrylamide) showing purification of CK from skeletal muscle of euthermic ground squirrels. Lane 1 contains Bio-Rad molecular weight markers; lane 2 shows the crude extract, and lanes 3 and 4 show purified CK after the DEAE and Cibacron Blue steps, respectively. The gel was stained with Coomassie blue. 


\section{Figure 3-8}

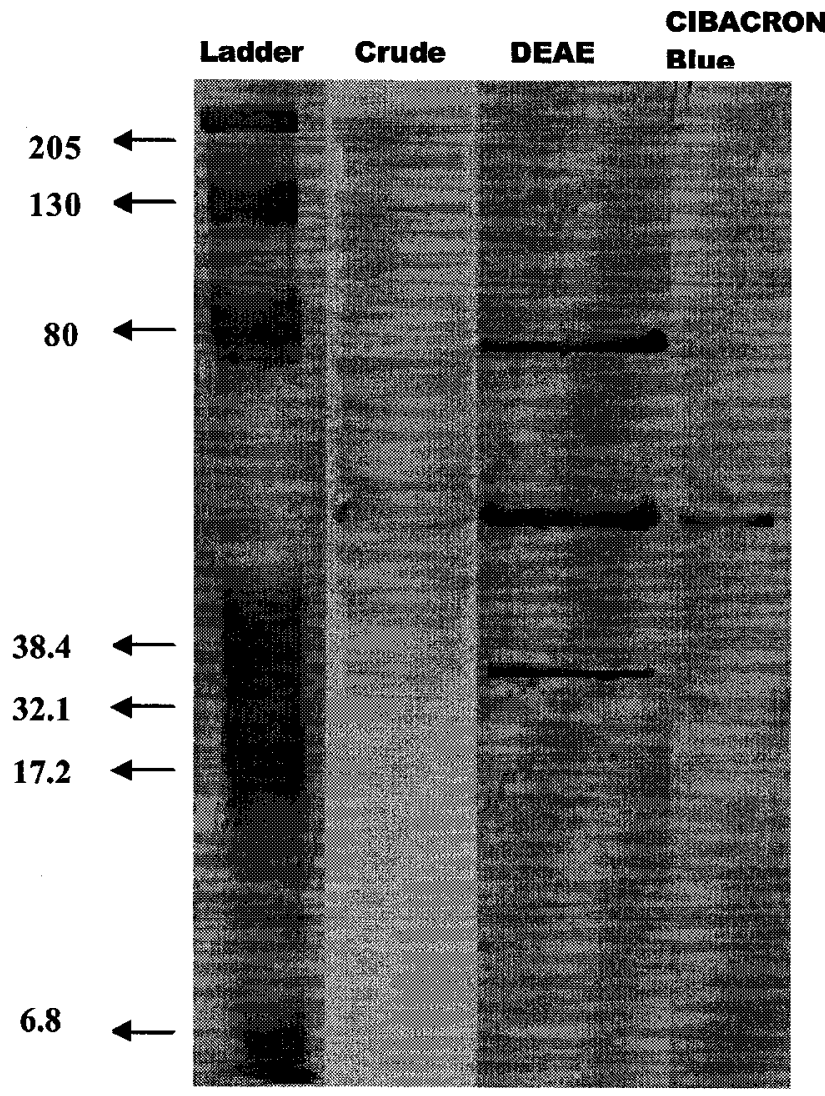


Figure 3-9. Analysis of the temperature and chemical stability of purified commercial rabbit muscle CK. A: Relative tryptophan fluorescence intensity of $\mathrm{CK}$ at the emission maximum as a function of $60 \mathrm{~min}$ incubations at different temperatures. Data were gathered at $\sim 5^{\circ} \mathrm{C}$ intervals between $2^{\circ}$ and $100^{\circ} \mathrm{C}$. B: Maximum emission wavelength of $\mathrm{CK}$ as a function of incubation temperature. C: Effect of $60 \mathrm{~min}$ incubation with different concentrations of guanidine hydrochloride $(\mathrm{GnHCl})$ on the subsequent emission maximum of CK. D: Effect of $60 \mathrm{~min}$ incubation with different concentrations of $\mathrm{GnHCl}$ on the recoverable activity of CK. $\mathbf{E}$ and F: Changes in the emission maximum wavelength and fluorescence intensity of ANS bound to CK after enzyme incubation with different concentrations of $\mathrm{GnHCl}$. Incubations with $\mathrm{GnHCl}$ were as above, followed by 30 min incubation with ANS and then measurement of ANS maximum emission wavelength (E) or fluorescence intensity at the emission maximum (F) that was determined in $\mathrm{E}$. Data are means $\pm \mathrm{SEM}, \mathrm{n}=5$. Where error bars are not visible, they are enclosed within the dimensions of the symbol. 
Figure 3-9
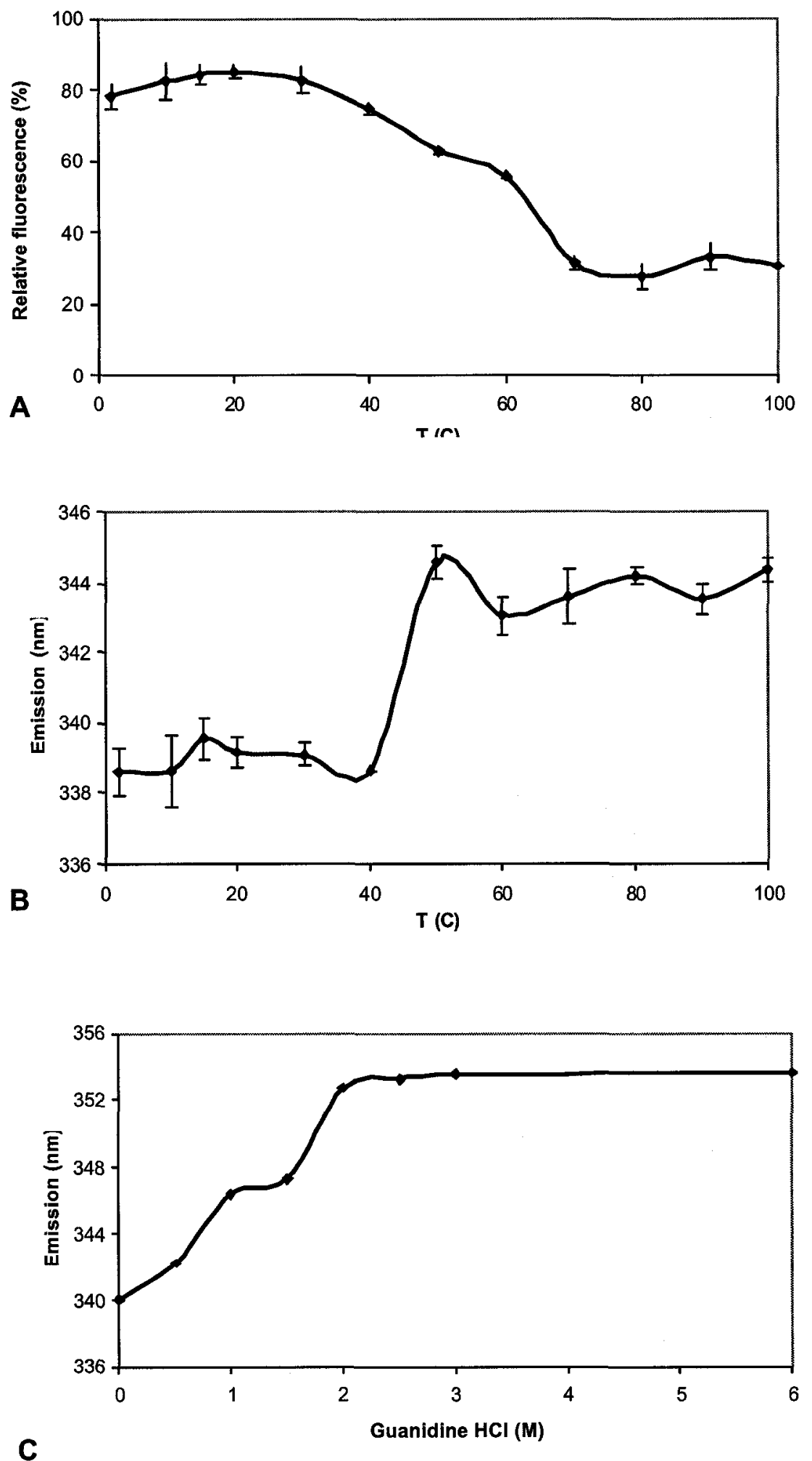
Figure 3-9 continued
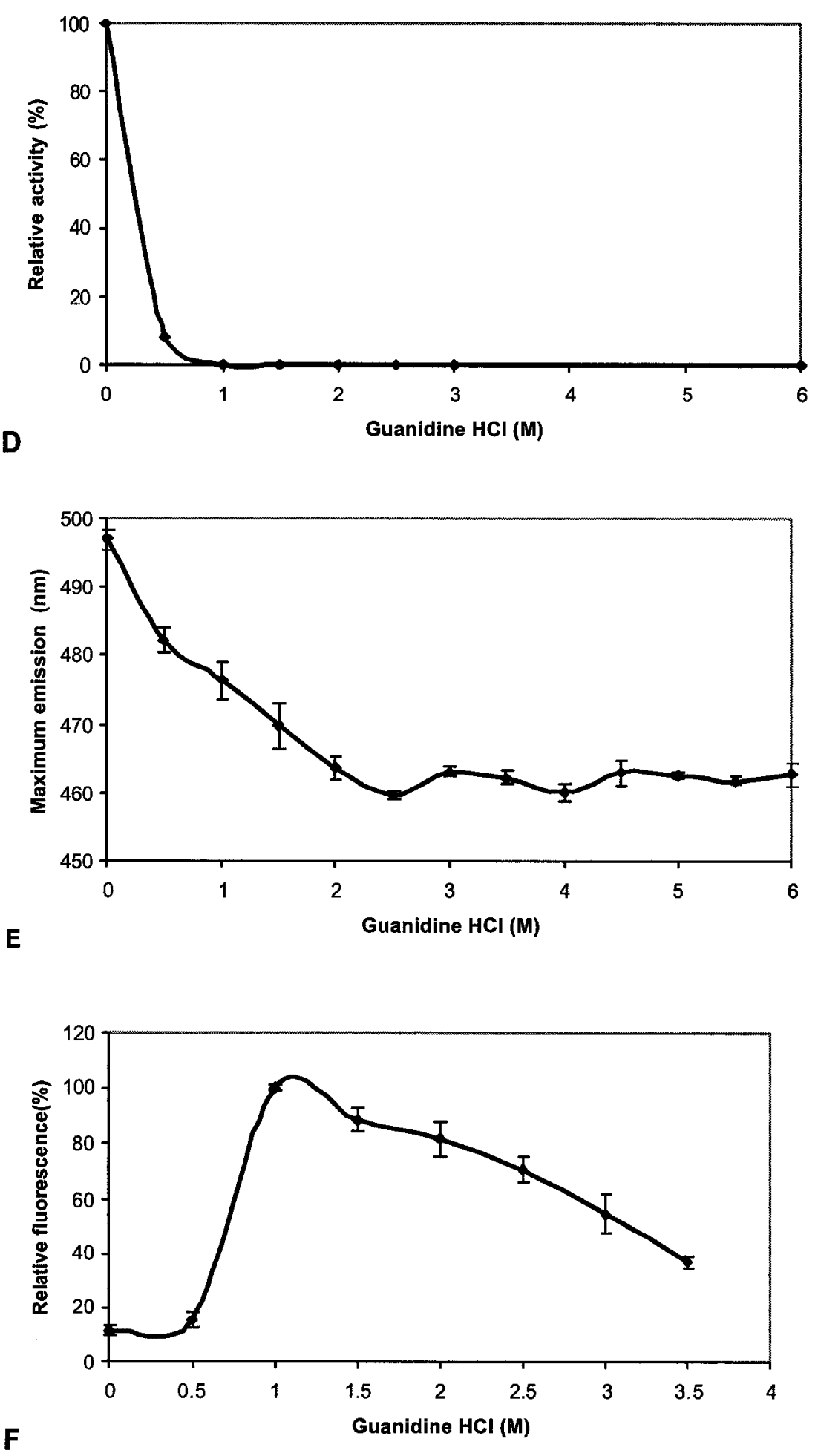
Figure 3-10. Analysis of the chemical stability of muscle CK from ground squirrels. A: Effect of $60 \mathrm{~min}$ incubation of purified euthermic CK with different concentrations of guanidine hydrochloride $(\mathrm{GnHCl})$ on the emission maximum for tryptophan fluorescence. B: Effect of $60 \mathrm{~min}$ incubation with different concentrations of $\mathrm{GnHCl}$ on the recoverable activity of purified euthermic CK. C: Structural stability of muscle CK from euthermic versus hibernating ground squirrels assessed by susceptibility to urea denaturation. Crude extracts were incubated for $24 \mathrm{~h}$ with different concentrations of urea followed by pulse proteolysis to degrade denatured CK (1 min incubation with thermolysin) and then Western blotting to measure the amount of native folded CK protein remaining. Comparable effects on purified commercial rabbit muscle CK are shown for comparison. Data are means $\pm S E M, n=5$; where error bars are not visible, they are enclosed within the dimensions of the symbol. 
Figure 3-10.
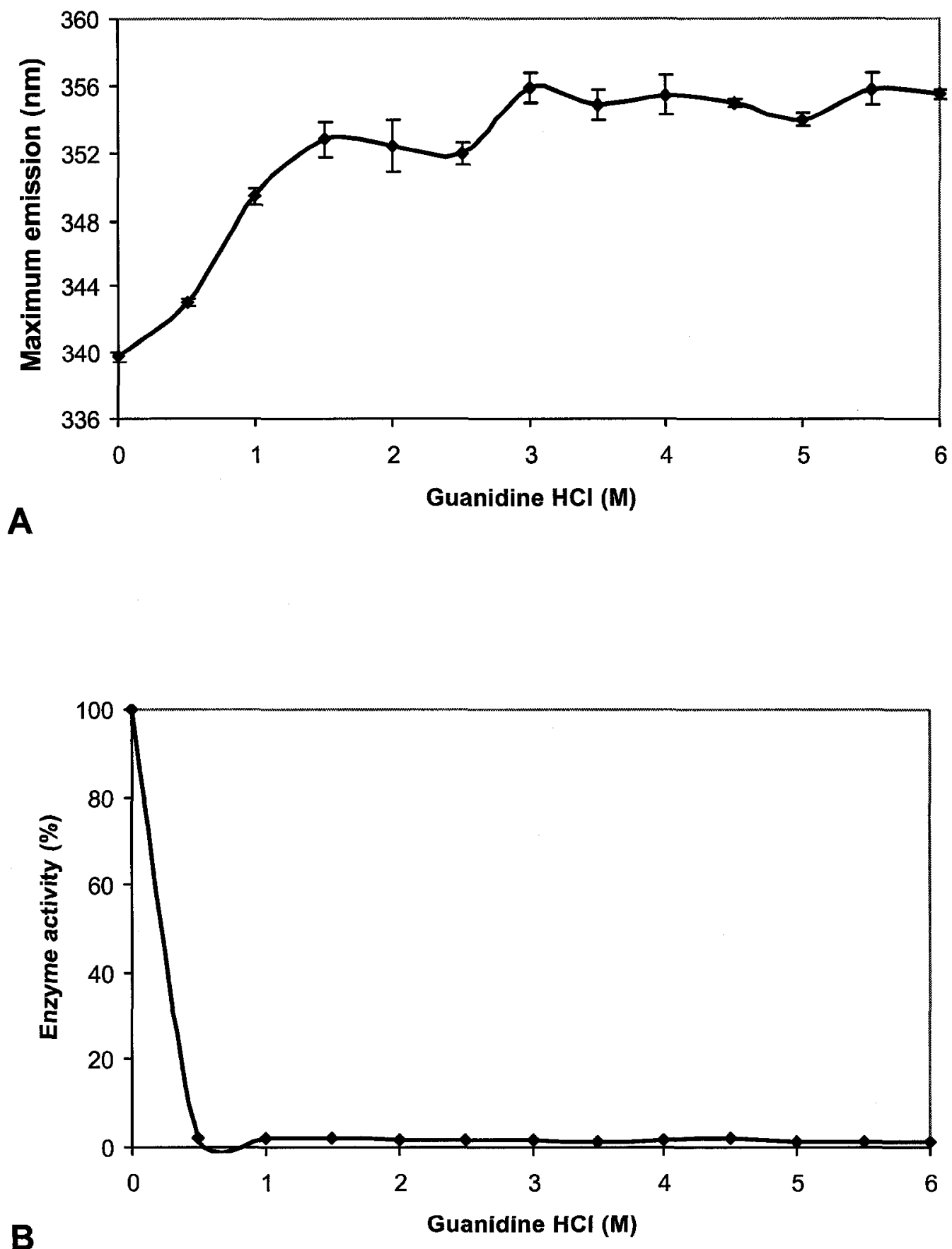
Figure 3-10 continued

Euhermic

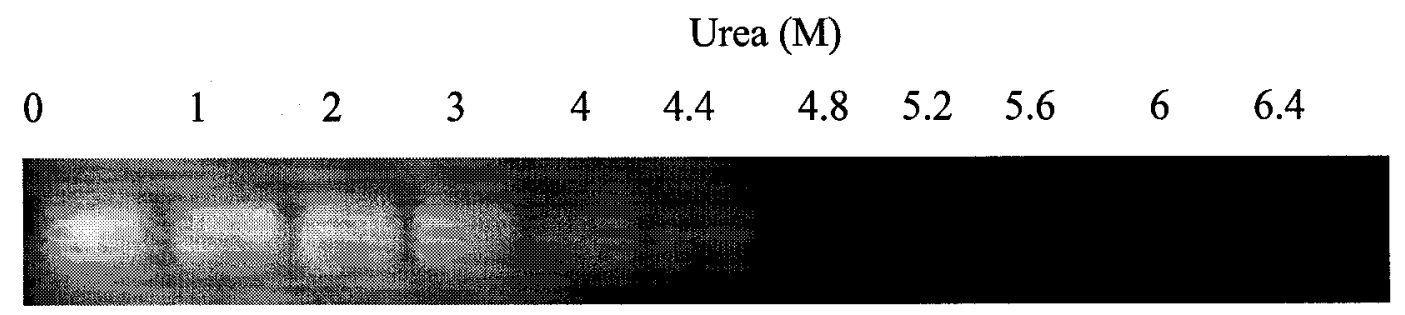

\section{Hibernating}

$\begin{array}{lllllllllll}0 & 1 & 2 & 3 & 4 & 4.4 & 4.8 & 5.2 & 5.6 & 6 & 6.4\end{array}$

\section{CK from Rabbit muscle}
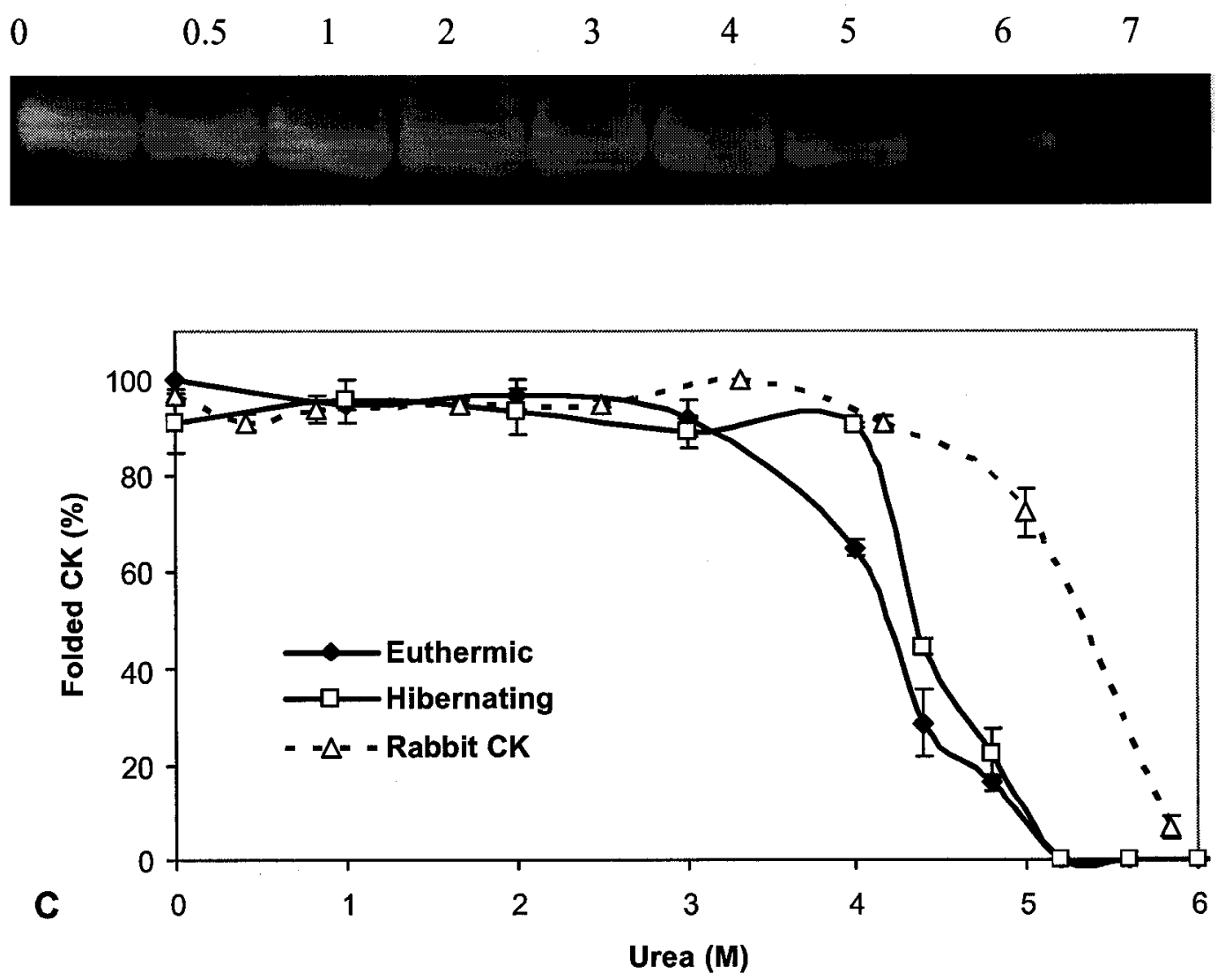


\section{Discussion}

The maintenance of muscle energetics during hibernation is important not just to long term viability but is also critical to the arousal process since shivering thermogenesis by skeletal muscle and nonshivering thermogenesis by brown adipose tissue are the two mechanisms that restore euthermic $\mathrm{Tb}$ to $37^{\circ} \mathrm{C}$ (Wang and Lee, 1996). Shivering thermogenesis results from ATP hydrolysis by myosin ATPase and is initiated after the hibernator body is partially rewarmed (at around $15^{\circ} \mathrm{C}$ ). Hence, enzymes involved in supporting muscle ATP supply for shivering thermogenesis are important and CK should be one of these. The present paper shows that skeletal muscle CK from euthermic versus hibernating animals shows markedly different kinetic properties, differential responses to temperature, and appears to be interconverted between two forms by reversible protein phosphorylation.

Both maximal CK activity and enzyme apparent affinity for creatine and ATP substrates decreased significantly during hibernation, as compared with euthermic muscle. The $20 \%$ decrease in maximal activity correlated with a comparable drop in CK protein content as measured by Western blotting (Figure 3-7) which suggests that the measured decrease in maximal activity may be the result of reduced $\mathrm{CK}$ protein during torpor. This may arise from an altered balance between protein synthesis and protein degradation in torpor and the strong reduction in CK mRNA levels in hibernator muscle (Figure 3-7) indicates that this may come from reduced CK gene transcription. Both transcriptional and translational suppression are well known in hibernation (Storey and Storey, 2004). However, reduced total CK during torpor is not necessarily negative since the rates of ATP turnover in the torpid state are very much lower and may not require 
concentrations of enzymes as high as in the euthermic state.

Kinetic properties of muscle $\mathrm{CK}$ also changed significantly between euthermic and hibernation states. $\mathrm{S}_{0.5}$ values for both substrates were significantly higher (substrate apparent affinity was lower) for the enzyme from hibernator muscle. Furthermore, the sigmoidal relationship between [ATP] and velocity was much stronger for hibernator CK $\left(\mathrm{n}_{\mathrm{H}}\right.$ rose from 1.49 to 2.49 ). This change in kinetic parameters for ATP would have significant consequences for enzyme function in vivo, particularly in light of a reduced adenylate pool in muscle during torpor. For example, ATP levels in S. lateralis muscle fell from $4.1 \mu \mathrm{mol} / \mathrm{g}$ wet weight in euthermia to $2.9 \mu \mathrm{mol} / \mathrm{gww}$ in hibernation (MacDonald and Storey, 1999). The effect of hibernation on muscle creatine pools is not known.

The present study found that $20-25 \%$ of CK was bound in ground squirrel muscle. Furthermore, bound euthermic CK had a significantly higher apparent affinity for creatine $\left(\mathrm{S}_{0.5}\right.$ decreased by $\left.26 \%\right)$. Turner et al. (1973) found that $\sim 10 \%$ of total cytoplasmic CK in chicken skeletal muscle was bound to myosin. Binding to the actomyosin complex is via two pairs of lysine residues that are highly conserved in MCK but are not found in B-CK (Hornemann et al., 2000). Besides a structural role for myosin bound MM-CK in the stability of the myosin filaments within the myofibrillar filament lattice (Strehler et al., 1983), this subcellular compartmentation appears to optimize the efficiency of the CK reaction in providing ATP to myosin ATPase. Moreover, CK molecules bound to myofibrils may equilibrate local ADP concentrations with those in rest of the cytoplasm (Lipskaya, 2001).

Prior evidence for phosphorylation of CK has been found. Ingwall (2002) 
reported a positive linear relationship between [AMP], AMPK velocity and CK velocity in normoxic rat hearts but, under low $\mathrm{pO}_{2}, \mathrm{CK}$ velocity fell $2-4$ fold while the increase in AMP-activated AMPK was modest. This suggests that AMPK is probably not the only protein kinase able to influence $\mathrm{CK}$ activity. Several reports also indicate phosphorylation of B-CK (Chida, 1990; Chida et al., 1990; Kuzhikandathil and Molloy, 1994; Hemmer et al., 1993). The present data indicate that ground squirrel skeletal muscle CK is a phosphoprotein and that its phosphorylation state changes between euthermic and hibernating states. This suggests that reversible phosphorylation contributes to the regulation of M-CK during hibernation. Analysis of the amino acid sequences of M-CK from rat, mouse and chicken show the presence of putative consensus sequences for the phosphorylation sites of PKA, PKC and PKG. Incubations under conditions that stimulated each of these protein kinases significantly suppressed soluble CK activity from euthermic muscle (Figure 3-4) as well as bound CK from hibernator muscle (Figure 3-5). However, stimulation of AMPK did not change CK activity. Incubations done in the presence of ${ }^{32} \mathrm{P}$-ATP found that stimulation of all four protein kinases increased ${ }^{32} \mathrm{P}$ labeling of CK. Hence, it appears that AMPK can catalyze phosphorylation of ground squirrel CK but, in doing so, does not alter enzyme maximal activity. Effects of PKA treatment of euthermic CK were further analyzed and showed that PKA treatment also reduced CK apparent affinity for ATP, mimicking the effects of hibernation on $\mathrm{S}_{0.5}$ ATP and its Hill coefficient.

Ground squirrel CK also responded to treatment with protein phosphatases. Incubations promoting total protein phosphatases, serine/threonine protein phosphatases, PP1, and PP2B all led to significant increases in soluble CK activity in extracts of both 
euthermic (16-30\% increase) and hibernating (12-39\% increase) muscle (Figure 3-4). Stimulation of total protein phosphatases also decreased $\mathrm{S}_{0.5}$ ATP and $\mathrm{n}_{\mathrm{H}}$ of hibernator CK to values close to those of euthermic CK. The pattern of response by hibernator CK to protein kinases (no effect) and protein phosphatases (activity increase) suggests that soluble CK in hibernating muscle is fully phosphorylated and that the enzyme must be dephosphorylated to revert to the euthermic condition. The responses by soluble euthermic CK are consistent with an enzyme that is partially phosphorylated (responds to both kinases and phosphatases) or with the presence of a mixed population of enzyme (some CK molecules phosphorylated and some not).

To distinguish between these possibilities, we used ion-exchange chromatography on DEAE Sephadex G50 to evaluate the elution profiles of CK from euthermic and hibernating ground squirrels (Figure 3-6). This showed that a mixture of phosphorylated (Peak II) and dephosphorylated (Peak I) CK was present in euthermia whereas during hibernation, only Peak II CK was detected. Incubation conditions that promoted protein phosphatase action in hibernator extracts shifted CK activity into Peak I whereas stimulation of PKA activity in euthermic extracts shifted all CK activity into Peak II. Hence, we conclude that soluble $\mathrm{CK}$ in ground squirrels exists in low and high phosphate forms with a mixed population in euthermic muscle and phosphorylated CK only in hibernation. Furthermore, a comparison of the kinetic properties of hibernating CK versus hibernating $\mathrm{CK}$ treated with phosphatases (both showing single peaks of $\mathrm{CK}$ activity; Figure 3-6) indicated that the low phosphate form (peak I) has significantly higher substrate apparent affinity for both ATP and creatine than the high phosphate form (peak II) (Table 3-1). 
We also analyzed the effects of reversible phosphorylation on CK from the bound fraction. Bound CK in euthermic muscle did not respond to protein kinase treatments but its activity was strongly increased by phosphatase treatments (Figure 3-5). Oppositely, CK from the bound fraction of hibernator muscle did not respond to phosphatase treatments but its activity was strongly suppressed by incubations with PKA, PKC or PKG. This suggests that $\mathrm{CK}$ in the bound fraction of euthermic muscle is a phosphoenzyme whereas in muscle from hibernating animals, bound CK is in a low phosphate form. Because myosin bound CK has a higher activity, and because there is no significant difference in bound CK content in euthermic and hibernating animals, it can be suggested that phosphorylation of CK would decrease its activity in the bound state. Incubation of resuspended pellets from hibernator muscle under conditions that enhanced protein kinases and phosphatases indicated that myosin bound $\mathrm{CK}$ in hibernating animals was not phosphorylated whereas this enzyme was phosphorylated in euthermic animals. From the experiments with free $\mathrm{CK}$, we expected that phosphorylated $\mathrm{CK}$ would show a higher $\mathrm{S}_{0.5}$ for both substrates. However, the $\mathrm{S}_{0.5}$ ATP values for bound and free CK from euthermic squirrels were not significantly different. Moreover, apparent affinity of bound euthermic CK for creatine was higher than the free enzyme. These results suggest that (a) phosphorylation or dephosphorylation does not change the apparent affinity of CK for myosin, and (b) binding to myosin could induce a conformational change that overcomes the effect of protein phosphorylation and changes the kinetic parameters of CK.

The activity of ground squirrel CK showed a linear response to temperature change in vitro with no indication of a "break" in the line such as would indicate a temperature-dependent conformational change. The Ea value for hibernating CK was 
$73.3 \mathrm{~kJ} / \mathrm{mol}$, significantly higher than the euthermic value of $57.1 \mathrm{~kJ} / \mathrm{mol}$ but both were similar to the Ea of purified rabbit $\mathrm{CK}(68.7 \mathrm{~kJ} / \mathrm{mol})$. Studies of the effect of temperature on $\mathrm{S}_{0.5}$ for creatine found that $\mathrm{S}_{0.5}$ decreased (apparent affinity increased) with decreasing temperature; the minimum value was at low temperature $\left(2-5^{\circ} \mathrm{C}\right)$ and $\mathrm{S}_{0.5}$ rose $\sim 3$-fold as temperature increased to near-euthermic values $\left(30^{\circ} \mathrm{C}\right)$. If muscle creatine concentrations were similar at high and low temperatures, this could effectively enhance CK function at low temperatures. The effects of temperature on $\mathrm{S}_{0.5}$ ATP values showed a different pattern and, in addition, ground squirrel CK responded differently to temperature change compared with the rabbit enzyme (Figure 3-3). Rabbit CK showed highest apparent affinity for ATP at $15-20^{\circ} \mathrm{C}$ (minimum $\mathrm{S}_{0.5}$ of $0.4 \mathrm{mM}$ ) with approximately 2 -fold higher $\mathrm{S}_{0.5}$ at $2^{\circ} \mathrm{C}$ and $30^{\circ} \mathrm{C}$, whereas ground squirrel $\mathrm{CK}$ showed its minimum $\mathrm{S}_{0.5}$ at $2^{\circ} \mathrm{C}$ with increasing values as temperature increased to $20-25^{\circ} \mathrm{C}$. At higher temperatures $\left(30^{\circ} \mathrm{C}\right)$, $\mathrm{S}_{0.5}$ values decreased again. Hence, the pattern of $\mathrm{S}_{0.5} \mathrm{ATP}$ versus temperature for hibernator CK shows lowest values (highest enzyme apparent affinity for substrate) at high and low temperatures that are similar to $\mathrm{Tb}$ in euthermia versus torpor, respectively, the two primary metabolic states in which these animals live. Furthermore, given that the total adenylate pool drops by about one-third during torpor (MacDonald and Storey, 1999; English and Storey, 2000), the ratio between muscle [ATP] and CK $\mathrm{S}_{0.5}$ ATP would remain nearly constant when euthermic and torpid $\mathrm{Tb}$ are compared. This phenomenon has been noted before in ectothermic animals and acts to maintain an optimal ratio of $K_{\mathrm{m}}$ versus [substrate] to preserve the metabolic scope for enzyme function over a wide temperature range (Hochachka and Somero, 1984). This phenomenon has been reported previously in hibernator (the prairie dog Cynomus 
leucurus) (English and Storey, 2000); $K_{\mathrm{m}}$ values for ATP, ADP and AMP of skeletal muscle adenylate kinase decreased by $40-60 \%$ between $37^{\circ}$ and $5^{\circ} \mathrm{C}$, paralleling a $\sim 40 \%$ decrease in total adenylates during torpor. $\mathrm{CK}$ function in hibernation might also be affected by a change in cytosolic $\mathrm{pH}$ during torpor and/or an interaction of $\mathrm{pH}$ and temperature effects on enzyme kinetics and/or binding to myosin. Studies with Columbian ground squirrels reported a muscle $\mathrm{pH}$ of 7.24 at $37^{\circ} \mathrm{C}$ and 7.45 at $5^{\circ} \mathrm{C}$ as measured by ${ }^{31} \mathrm{P}$ NMR (McArthur et al., 1990). Because of $\mathrm{CO}_{2}$ retention during entry into torpor, the measured $\mathrm{pH}$ in hibernator muscle is lower (constituting a relative acidosis) than the predicted value of 7.78 that should result from the effect of temperature on the $\mathrm{pH}$ histidine-based intracellular buffers alone.

Structural studies were used to compare ground squirrel and rabbit CK to determine if the enzyme from a hibernating species showed differences in stability in response to denaturants in comparison with the enzyme from a non-hibernator. Such differences could reflect structural changes in the hibernator enzyme that could allow the enzyme to function effectively over a wide temperature range in vivo. Chemical denaturation of both euthermic ground squirrel and rabbit $\mathrm{CK}$ using $\mathrm{GnHCl}$ showed that structural denaturation occurred through a stable intermediate. Maximum emission wave length occur at $3 \mathrm{M} \mathrm{GnHCl}$ in $\mathrm{CK}$ from Euthermic ground squirrels in comparison to the rabbit enzyme, 2M GnHCl CK from both animals had a much faster loss of enzymatic activity (90-100\% activity loss at $0.5 \mathrm{M} \mathrm{GnHCl}$ than of structural stability. This suggests that the conformation of the active site is much more sensitive to disruption that is the overall 3D structure of enzyme (Bai et al., 1998). However, we discerned no major differences in the responses to guanidine $\mathrm{HCl}$ between the ground squirrel and rabbit 
enzymes. Since a high proportion of soluble CK from euthermic muscle is phosphorylated, this could also suggest that phosphorylation of $\mathrm{CK}$ does not alter its overall structural stability with respect to guanidine $\mathrm{HCl}$ denaturation. The hydrophobic dye binding experiment with ANS showed that most of the hydrophobic residues are exposed at concentration of $1 \mathrm{M}$ guanidine hydrochloride.

Analysis of CK stability with respect to urea denaturation revealed that rabbit muscle CK was considerably more stable than ground squirrel CK. The structure of ground squirrel CK was disrupted and rendered susceptible to thermolysin proteolysis at concentrations of 3-4 M urea and treatment with $5 \mathrm{M}$ urea caused $>90 \%$ denaturation. By contrast, only $\sim 10 \%$ of the rabbit protein was degraded after treatment with $5 \mathrm{M}$ urea. The species difference in CK stability may derive from small differences in protein structure. Rabbit CK may have a more rigid structure than ground squirrel CK because it normally functions within a narrow thermal window. By contrast, greater flexibility of ground squirrel $\mathrm{CK}$ would aid the enzyme in maintaining its function over the wide range of $\mathrm{Tb}$ values $\left(0\right.$ to $\left.37^{\circ} \mathrm{C}\right)$ that are naturally encountered between euthermic and torpid states. Our data from chemical denaturation with both urea and $\mathrm{GnHCl}$ showes that $\mathrm{CK}$ from Euthermic Richardson' ground squirrel is less stable than CK from Rabbit muscle.

Overall, the present study shows that muscle CK from euthermic and hibernating ground squirrels displays significantly different kinetic parameters $\left(S_{0.5}\right.$ and $\left.V_{\max }\right)$ that could optimize enzyme function in warm, active versus cold, torpid states. Reversible phosphorylation, changes in total $\mathrm{CK}$ protein and $\mathrm{mRNA}$ contents, and $\mathrm{CK}$ binding to myofibrils all appear to play key roles in regulating CK with respect to hibernation. 


\section{Chapter 4}

\section{AMP DEAMINASE REGULATION IN GROUND SQUIRRELS DURING HIBERNATION}




\section{Introduction}

One of the features of hibernation is an overall reduction in the total adenylate pool (ATP + ADP + AMP) of organs; pool size drops by 30-50\% in different species (Kelly and Storey, 1995; MacDonald and Storey, 1999; English and Storey, 2000). Despite this, a viable energy status must be maintained over weeks of cold torpor and energy charge, $[\mathrm{ATP}+0.5 \mathrm{ADP}] /[\mathrm{ATP}+\mathrm{ADP}+\mathrm{AMP}]$, remains high.

A decrease in the total adenylate pool, while maintaining energy charge, is a wellknown phenomenon in working skeletal muscle and is accomplished by the action of two enzymes. ATP hydrolysis during muscle contraction elevates ADP and stimulates the adenylate kinase reaction $(2 \mathrm{ADP} \rightarrow \mathrm{AMP}+\mathrm{ATP})$ which helps to elevate ATP availability. However, this results in AMP accumulation which is then minimized by draining AMP from the adenylate pool via the AMP-deaminase (AMPD; AMPaminohydrolase, EC 3.5.4.6) reaction that converts AMP to inosine 5'-monophosphate (IMP). Coordination of adenylate kinase AMP and deaminase maintains a high ATP / ADP ratio and adenylate energy charge in the cell (Lowenstein, 1990; Rundel et al., 1992). Multiple forms of AMPD have been purified from human tissues/cells and are named for the ir initial source: M, muscle; L, liver; E, erythrocyte (Ogasawara et al., 1982). They are encoded by the genes ampd1 (Sabina et al., 1990), ampd2 (BauschJurken et al., 1992), and ampd3 (Mahnke-Zizelman and Sabina, 1992), respectively. Morisaki, Sabina and Holmes (1990) reported that ampdl is expressed in high levels in skeletal muscle of adult rats but ampd2 was almost undetectable, whereas ampd1 and ampd2 were both expressed at the same level in heart. Using immunoprecipitation, 
Mahnke-Zizelman and Sabina (1992) showed that M-AMPD dominated in human skeletal muscle (>95\%) with L and $\mathrm{E}$ isozymes contributing $<5 \%$ each

Multiple mechanisms are involved in AMPD regulation (Hancock et al., 2006). Typically AMPD activity increases as $\mathrm{pH}$ decreases down to 6.5 (Dudley and Terjung, 1985; Martini et al., 2001) and this sensitivity to acidic $\mathrm{pH}$ is believed to enhance enzyme function in working muscle when cellular $\mathrm{pH}$ drops. AMPD is allosterically regulated by $\mathrm{ADP}$ and ATP as activators and by inorganic phosphate $(\mathrm{Pi})$ as an inhibitor (Wheeler and Lowenstein, 1979, 1980). Moreover, AMPD shows reversible binding to myosin which increases its activity (Ashby and Frieden, 1977, 1978; Barshop and Frieden, 1984); Shiraki et al., 1979; Ichiro et al, 1998). Rundel et al. (1992) reported that in resting muscle about $90 \%$ of AMPD is free in the cytoplasm. The same situation occurred under at low contraction rates when energy balance was well maintained, but during intense contractions that increased [IMP], bound AMPD content increased to $\sim 60 \%$ in fast twitch and $\sim 50 \%$ in slow twitch muscle. Rush et al. (1998) showed that protein phosphorylation could be important in the in vivo control of AMPD by increasing the molecular activity of the enzyme under physiological AMP concentrations. Tovmasian et al. (1990) reported that protein kinase $\mathrm{C}$-dependent phosphorylation of AMPD did not affect maximal enzyme activity but lowered the $\mathrm{K}_{\mathrm{m}}$ AMP from 0.6 to $0.2 \mathrm{mM}$.

In an earlier study, English and Storey (2000) examined some properties of AMPD purified from skeletal muscle of white-tailed prairie dogs, Cynomus leucurus, a hibernating species. Kinetic parameters of the enzyme from euthermic (body temperature $37^{\circ} \mathrm{C}$ ) animals were assessed at 37 and $5^{\circ} \mathrm{C}$, temperatures characteristic of euthermic and hibernating states, respectively. This analysis showed that temperature change had strong 
effects on the sensitivity of the enzyme to ions and metabolite inhibitors and activators. However, the possibility that AMPD was modified in vivo (such as by reversible phosphorylation) to optimize its function in the hibernating state was not examined. The present chapter focuses on different aspects of AMPD regulation, in particular the differences in kinetic properties and phosphorylation state of the enzyme in euthermic versus hibernating animals. Skeletal muscle AMPD from Richardson's ground squirrel (RGS) (Spermophilus richardsonii) and the thirteen-lined ground squirrel (TLGS) (Spermophilus tridecemlineatus) were analyzed by evaluating activity and kinetic parameters of the enzyme from euthermic and torpid animals, effects of activators and inhibitors, reversible phosphorylation of the enzyme, and the interacting effects of temperature on kinetic parameters to determine how AMPD is regulated during torpor.

\section{Materials and methods}

\section{Animals}

Animal collection, holding, feeding and conduct of hibernation experiments were as described previously in detail for Richardson's ground squirrels (MacDonald and Storey, 2005) and thirteen-lined ground squirrels (Morin and Storey, 2005). Refer to Chapter 2 for more details.

\section{Preparation of tissue extracts}

Samples of hind leg skeletal muscle were homogenized 1:5 w:v in buffer A [50 $\mathrm{mM}$ Tris buffer, $\mathrm{pH} 7.5,50 \mathrm{mM} \beta$-glycerophosphate ( $\beta$-GP), $1 \mathrm{mM}$ EDTA, $1 \mathrm{mM}$ EGTA, $10 \mathrm{mM} \beta$-mercaptoethanol ( $\beta$-MeSH)] with a few crystals of the protease 
inhibitor, phenylmethylsulfonyl fluoride (PMSF) added just prior to homogenization. Homogenates were centrifuged at $25,000 \mathrm{~g}$ for $15 \mathrm{~min}$ and then the supernatant was removed and stored on ice.

\section{Enzyme assay}

AMPD activity (AMP $\rightarrow$ IMP $+\mathrm{NH}_{4}^{+}$) was assayed at $285 \mathrm{~nm}$ using a Multiskan Spectrum microplate reader to measure the rate of IMP production Both AMP and IMP absorb at this wavelength, but the molar absorption constant is much lower for AMP ( 0.32 for IMP compared to 0.16 for AMP); therefore the rate of IMP production is equal to rate of change in absorbance divided by 0.16 . Optimal assay conditions were determined to be $50 \mathrm{mM}$ Tris buffer (pH 7.4 for TLGS and 7.2 for RGS) and $10 \mathrm{mM}$ AMP. Routine assays were run at $22^{\circ} \mathrm{C}$ and used $20 \mu 1$ of supernatant; one unit is defined as the amount of enzyme that produced $1 \mu \mathrm{mol}$ IMP per minute at $22^{\circ} \mathrm{C}$.

\section{Incubations to stimulate protein phosphatase or kinase activities}

Samples of supernatant were incubated for $4 \mathrm{~h}$ at $22^{\circ} \mathrm{C}$ with specific inhibitors and stimulators of protein kinases or protein phosphatases as described previously (MacDonald and Storey, 1999) and with greater detail in Chatpter 2 of this thesis with following changes. Because NaF inhibits AMPD activity, $50 \mathrm{mM} \beta$-glycerol phosphate was used to inhibit protein phosphatases. Moreover $\mathrm{pH}$ of incubation buffers was 7.5. After incubation, additives were removed by low speed centrifugation of samples through small columns of Sephadex G15 equilibrated in buffer A followed by assay of AMPD activity under optimal conditions. 
To confirm that there was no effect of incubation time or additives on AMPD in the absence of the endogenous protein kinases or protein phosphatases present in the crude extract, sample s of commercial pure rabbit AMPD (Sigma) were incubated under each of the conditions used above followed by removal of additives by centrifuging through Sephadex G15 and assay of AMPD. Rabbit AMPD activity was unaltered after incubation under every condition.

\section{DEAE ion exchange chromatography}

Muscle extracts were prepared 1:5 w:v in homogenizing buffer as above. A 500 $\mu 1$ aliquot of crude extract was applied to a DEAE Sephadex G50 column $(1.5 \mathrm{~cm} \times 5$ $\mathrm{cm}$ ) equilibrated in buffer $\mathrm{A}$ at $\mathrm{pH}$ 7.0. The column was washed with the buffer and then eluted with a linear $\mathrm{KCl}$ gradient $(0-2 \mathrm{M})$ in the same buffer. Activity in the fractions was measured.

\section{Data, statistics and protein determination \\ Data were analyzed as described in Chapter 2.}

\section{Results}

\section{Kinetic analysis of ground squirrel muscle AMPD}

Initial studies optimized homogenization conditions for retrieving maximum AMPD activity in soluble extracts from ground squirrel skeletal muscle. The inclusion of protein kinase inhibitors (EDTA/EGTA) or the protein phosphatase inhibitor $(\beta-\mathrm{GP})$ in the homogenization buffer did not affect the measurable amount of AMP deaminase but 
the presence of $\mathrm{NaF}$, another phosphatase inhibitor, reduced the AMPD retrieved by $87 \%$; hence, standard ho mogenization conditions omitted NaF. Crude preparations of muscle AMPD prepared as described in the Methods and stored at $5^{\circ} \mathrm{C}$ were stable up to 48 hours. The $\mathrm{pH}$ optimum of AMPD was determined to be 7.4 for the enzyme from TLGS and pH 7.2 for RGS and did not differ between euthermic and hibernating states (Figure 4-1).

The maximum activity of AMPD in soluble extracts of RGS skeletal muscle was $522 \pm 41 \mathrm{mU} / \mathrm{g}$ wet weight in euthermic squirrels and significantly lower, $166 \pm 20$ $\mathrm{mU} / \mathrm{gww}$, during torpor, a reduction of about $70 \%$ compared to euthermia $(\mathrm{n}=7 ; \mathrm{P}<0.05)$. AMPD activity in euthermic TLGS muscle was $1131 \pm 13 \mathrm{mU} / \mathrm{gww}$ and $184 \pm 15$ $\mathrm{mU} / \mathrm{gww}$ in hibernating animals, an $84 \%$ reduction during torpor $(\mathrm{n}=7 ; \mathrm{P}<0.05)$.

Velocity versus substrate concentration curves for muscle AMPD in crude extracts from both euthermic and hibernating ground squirrels are shown in Figure 4-2 and data on AMP substrate apparent affinity is summarized in Table 4-1. For both species, the velocity versus [AMP] relationship for euthermic AMPD showed a sigmoidal relationship with Hill coefficients of 2.49 for TLGS and 1.74 for RGS. The enzyme from muscle of hibernating animals, however, showed a hyperbolic velocity versus [AMP] profile. Apparent affinity for AMP differed significantly between the two states. The $\mathrm{S}_{0.5}$ AMP for AMPD from hibernating animals was 34\% and 37\% higher for RGS and TLGS, respectively, than for the corresponding euthermic enzyme $(\mathrm{P}<0.05)$ (Table 4-1).

Muscle AMPD is known to bind to myosin and a portion of total AMPD remains in the pellet under normal homogenization and centrifugation conditions. Pellets from the original preparations were re-extracted four times with homogenization buffer to remove 
any unbound AMPD and then bound AMPD was released into the supernatant by a final extraction using $500 \mathrm{mM} \mathrm{KCladded} \mathrm{to} \mathrm{the} \mathrm{homogenization} \mathrm{buffer.} \mathrm{This} \mathrm{procedure}$ showed that $36.8 \pm 2.2$ and $35.3 \pm 2.3 \%$ of total muscle AMPD was bound to myosin in euthermic and hibernating squirrels, respectively; the difference was not significant.

\section{Temperature effects on AMPD}

The effect of temperature on RGS AMPD activity is shown as Arrhenius plots in Figure 4-3. The relationship was linear over the range of temperatures tested $\left(5-22^{\circ} \mathrm{C}\right)$. Calculated activation energy, Ea, for AMPD from euthermic ground squirrels was $115 \pm$ $8 \mathrm{~kJ} / \mathrm{mol}$ and $26 \%$ higher $(\mathrm{P}<0.05)$ at $144 \pm 9 \mathrm{~kJ} / \mathrm{mol}$ for hibernating animals.

Figure 4-4 shows the effect of temperature on $S_{0.5}$ AMP for RGS. Because of very low activity we were not able to measure $S_{0.5}$ over the range of $0-10^{\circ} \mathrm{C} . \mathrm{S}_{0.5}$ AMP did not change significantly when assessed at $10,22,30$ and $35^{\circ} \mathrm{C}$ in extracts from hibernating animal. For the enzyme from euthermic animals $S_{0.5}$ in 10 and $22^{\circ} \mathrm{C}$ remain stable but $\mathrm{S}_{0.5}$ AMP decreased by about $35 \%$ at higher temperatures $\left(30\right.$ and $\left.35^{\circ} \mathrm{C}\right)$.

\section{Effectors of AMPD}

Allosteric regulation by small molecules is a well-known mechanism of AMPD regulation; these include nucleotides such as ATP and ions $\left(\mathrm{NH}_{4}{ }^{+}, \mathrm{Mg}^{2+}, \mathrm{PO}_{4}{ }^{3-}\right)$. Table 42 shows $K_{a}$ ATP and the $I_{50}$ values for ions for AMPD in crude muscle extracts of euthermic and hibernating RGS. $\mathrm{K}_{\mathrm{a}}$ ATP was $74 \%$ higher for the enzyme from hibernating, compared with euthermic, animals. AMPD from hibernating animals was also more sensitive to inhibition by $\mathrm{Mg}^{2+}$ but much less sensitive to inhibition by $\mathrm{NH}_{4}^{+}$ 
and $\mathrm{PO}_{4}{ }^{3-}$ with $\mathrm{I}_{50}$ values that were 3.6- and 2.3-fold higher, respectively, in comparison to euthermic AMPD. $\mathrm{NaCl}$ and $\mathrm{KCl}$ were also tested at levels between $0-1 \mathrm{M}$ but did not inhibit the ground squirrel enzyme.

\section{Reversible phosphorylation of AMPD}

To determine if reversible protein phosphorylation could be responsible for the differences in AMPD properties between euthermic and hibernating states, tissue extracts were incubated under conditions that stimulated the actions of endogenous protein kinases or protein phosphatases and the resulting effects on AMPD maximal activity were measured. AMPD activity in control euthermic extracts (no additions) was significantly higher (2.4-fold) than in hibernator extracts. Incubations under conditions that promoted protein phosphatase action significantly decreased AMPD activity in euthermic extracts in all cases. Stimulation of total protein phosphatases, total serine/threonine protein phosphatases (TST), PP1, PP2B and PP2C reduced AMPD activity in euthermic extracts by $67,82,54,75$, and 92\%, respectively (Fig. 4-5A). Furthermore, incubation with commercial calf intestine alkaline phosphatase reduced euthermic AMPD activity by $73 \%$. Equivalent incubations of muscle extracts from hibernating animals did not change the activity of AMPD significantly.

Stimulation of protein kinases A, C and G increased AMPD activity in RGS muscle extracts from both euthermic and hibernating animals (Fig. 4-5B). Activity in euthermic extracts increased by about 4-fold in all cases. Stimulation of protein kinases A, C and G increased activity in hibernator extracts by 6,3 and 9 fold, respectively. Stimulation of AMPK did not change the activity of AMPD in either euthermic or 
hibernator muscle extracts.

Incubations that facilitated protein kinase or phosphatase action on AMPD also altered enzyme apparent affinity for AMP (Table 4-1). Stimulation of PKC, PKG and AMPK in muscle extracts from euthermic RGS reduced $\mathrm{S}_{0.5}$ AMP significantly by 27,38 , and 53\%, respectively. Treatment with alkaline phosphatase had the opposite effect and increased $\mathrm{S}_{0.5}$ significantly by $34 \%$ to a value close to that of the control hibernator value. Moreover, the activity versus [AMP] relationship was strongly sigmoidal for the alkaline phosphatase treated enzymes from both euthermic and hibernating animals. Stimulation of protein kinase activities also significantly reduced the $\mathrm{S}_{0.5}$ AMP of AMPD in hibernator extracts; the $S_{0.5}$ value decreased by $55,77,73$ and $63 \%$ respectively, when PKA, PKC, PKG or AMPK were stimulated. However, treatment with alkaline phosphatase did not have a significant effect on $\mathrm{S}_{0.5}$ AMP of the hibernator enzyme but did increase the sigmoidicity of the relationship. When comparable incubations were carried out using purified commercial AMPD (Sigma), no significant changes in enzyme maximal activity were seen between untreated control incubations and incubations of pure enzyme in each of the incubation solutions (results not shown.).

\section{Ion exchange chromatography of AMPD}

High and low phosphate forms of enzymes can frequently be separated by ion exchange chromatography because phosphorylation alters the net charge on the enzyme. Figure 46A shows the elution patterns of RGS muscle AMPD activity from DEAE-Sephadex 50 using a 0-2 $\mathrm{M} \mathrm{KCl}$ gradient and comparing elution patterns for euthermic and hibernating situations. AMPD eluted in two peaks in muscle extracts from both euthermic and 
hibernating animals (Fig. 4-6A). With euthermic extracts, the enzyme eluted at medium and high salt, peaks II and III, concentrations; peak fractions were 15 and 24 for the representative run shown in Fig. 4-6A. However, the two peaks for hibernating AMPD eluted at low and medium $\mathrm{KCl}$ concentrations, Peak I and II (peak fractions were 5 and 15). Muscle extracts were then incubated under conditions that promoted PKG activity in hibernator extracts or that treated euthermic extracts with alkaline phosphatase. Treatment of euthermic AMPD with AP shifted the majority of activity into the peak eluting at low $[\mathrm{KCl}]$ (fraction 5, peak I) with only two very tiny peaks at fractions 15 and 24 (Fig. 4-6B). Oppositely, stimulation of PKG in hibernator extracts shifted the elution pattern to two peaks eluting at medium and high [KCl] (peaks II and III). 
Table 4-1. $\mathrm{S}_{0.5}$ values for skeletal muscle AMPD from euthermic versus hibernating ground squirrels. Values for the crude enzyme from both species are presented as well as the effects on $S$. richardsonii AMPD of incubation under conditions that stimulated protein kinases (PKA, PKC, PKG, AMPK) or treatment with alkaline phosphatase (AP). Assays were conducted at $22^{\circ} \mathrm{C}$ and enzyme parameters were determined using an enzyme kinetics package that fitted data to the Michaelis Menten or Hill equations (Brooks, 1992). Data are means $\pm \mathrm{SEM}, \mathrm{n}=4$ independent determinations on separate preparations of enzyme. a - Significantly different from the corresponding value for the euthermic enzyme using the Student's t-test, $\mathrm{P}<0.05 ; \mathrm{b}$ - significantly different from the corresponding untreated control incubation, $\mathrm{P}<0.05$.

\begin{tabular}{|c|c|c|c|c|}
\hline & $\begin{array}{l}\text { Euthermic } \\
\mathrm{S}_{0.5} \text { AMP, mM }\end{array}$ & $\mathrm{n}_{\mathrm{H}}$ & $\begin{array}{l}\text { Hibernating } \\
\mathrm{S}_{0.5} \mathrm{AMP}, \mathrm{mM}\end{array}$ & $\mathrm{n}_{\mathrm{H}}$ \\
\hline \multicolumn{5}{|c|}{ Thirteen-lined ground squirrel } \\
\hline Control & $1.68 \pm 0.22$ & $2.49 \pm 0.16$ & $2.67 \pm 0.18^{\mathrm{a}}$ & $1.26 \pm 0.17^{\mathrm{a}}$ \\
\hline \multicolumn{5}{|c|}{ Richardson's ground squirrel } \\
\hline Control & $1.92 \pm 0.22$ & $1.74 \pm 0.22$ & $2.91 \pm 0.31^{\mathrm{a}}$ & $1.15 \pm 0.25^{\mathrm{a}}$ \\
\hline $\mathrm{AP}$ & $2.56 \pm 0.18^{b}$ & $3.25 \pm 0.55$ & $2.67 \pm 0.23$ & $2.67 \pm 0.39$ \\
\hline PKA & $1.91 \pm 0.21$ & $1.10 \pm 0.15$ & $1.31 \pm 0.15^{\mathrm{a}, \mathrm{b}}$ & $1.12 \pm 0.20$ \\
\hline PKC & $1.39 \pm 0.08^{b}$ & $1.25 \pm 0.35$ & $0.68 \pm 0.06^{\mathrm{a}, \mathrm{b}}$ & $1.20 \pm 0.18$ \\
\hline PKG & $1.18 \pm 0.15^{b}$ & $1.35 \pm 0.28$ & $0.79 \pm 0.20^{b}$ & $1.16 \pm 0.0 .30$ \\
\hline AMPK & $0.89 \pm 0.09^{b}$ & $1.18 \pm 0.12$ & $1.09 \pm 0.13^{b}$ & $1.24 \pm 0.20$ \\
\hline
\end{tabular}


Table 4-2. Activators and inhibitors of Richardson's ground squirrel muscle AMPD. Data are means \pm SEM, $n=4$ independent determinations on different preparations of enzyme. All assays were at $22^{\circ} \mathrm{C}$ with an AMP substrate concentration of $3 \mathrm{mM}$. a Significantly different from the corresponding value for euthermic AMPD using the Student's t-test, $\mathrm{P}<0.05$.

\begin{tabular}{|l|l|l|}
\hline & Euthermic & Hibernating \\
\hline $\mathrm{Ka} A T P, \mathrm{mM}$ & $0.14 \pm 0.01$ & $0.24 \pm 0.01^{\mathrm{a}}$ \\
\hline $\mathrm{I}_{50} \mathrm{MgCh}, \mathrm{mM}$ & $30.5 \pm 4.9$ & $21.0 \pm 2.0^{\mathrm{a}}$ \\
\hline $\mathrm{I}_{50} \mathrm{NH}_{4} \mathrm{Cl}, \mathrm{mM}$ & $80.0 \pm 6.5$ & $294 \pm 44.1^{\mathrm{a}}$ \\
\hline $\mathrm{I}_{50} \mathrm{PO}_{4}{ }^{3-}, \mathrm{mM}$ & $88.1 \pm 12.6$ & $205 \pm 24.5^{\mathrm{a}}$ \\
\hline
\end{tabular}


Figure 4-1. Effect of $\mathrm{pH}$ on the activity of skeletal muscle AMPD from euthermic and hibernating 13-lined ground squirrels (A) and Richardson's ground squirrels (B). Activity was assayed in $50 \mathrm{mM}$ Tris buffer with $10 \mathrm{mM}$ AMP as the substrate. Data are means \pm SEM, $n=4$ independent determinations on different preparations of enzyme. 
Figure 4-1
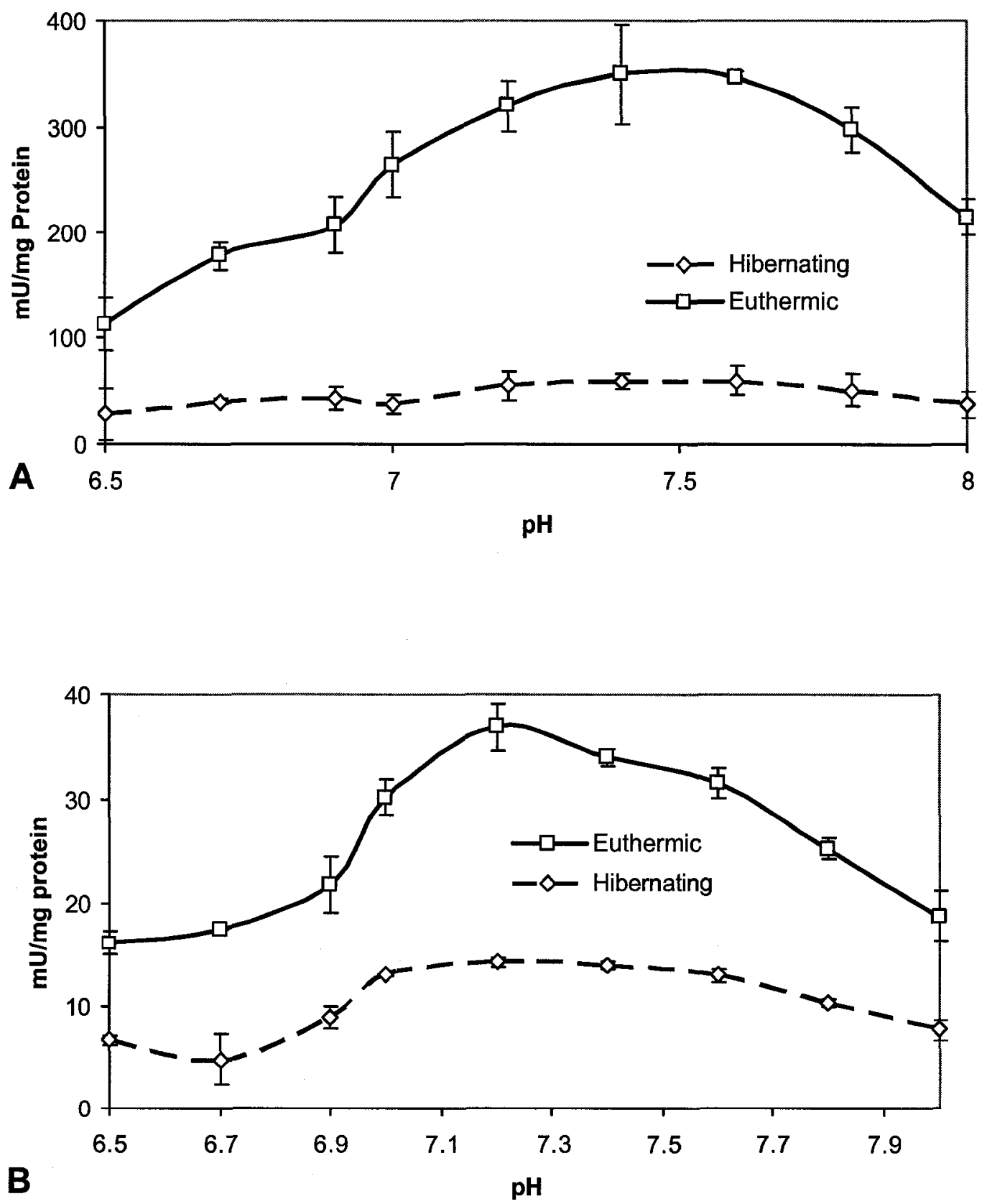
Figure 4-2. Activity versus AMP substrate concentration relationships for muscle AMPD from euthermic and hibernating 13-lined ground squirrels (A) or Richardson's ground squirrels (B). Data are milliunits/mg protein, means $\pm S E M, n=5$ independent determinations on different preparations of enzyme. 
Figure 4-2
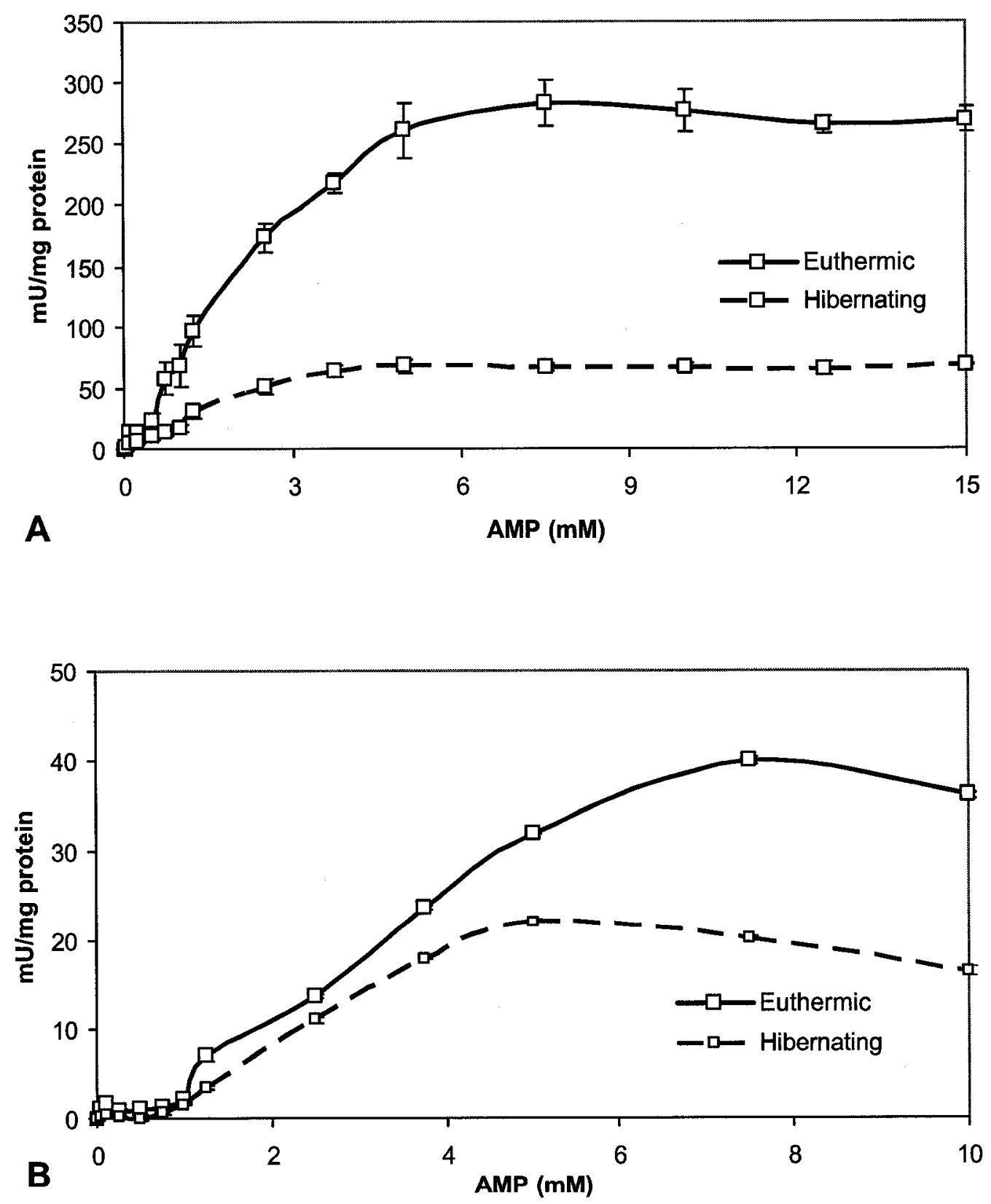
Figure 4-3. Arrhenius plots for AMPD from skeletal muscle of euthermic and hibernating Richardson's ground squirrels. Data are means $\pm S E M, n=5$ independent determinations on different preparations of enzyme. 
Figure 4-3

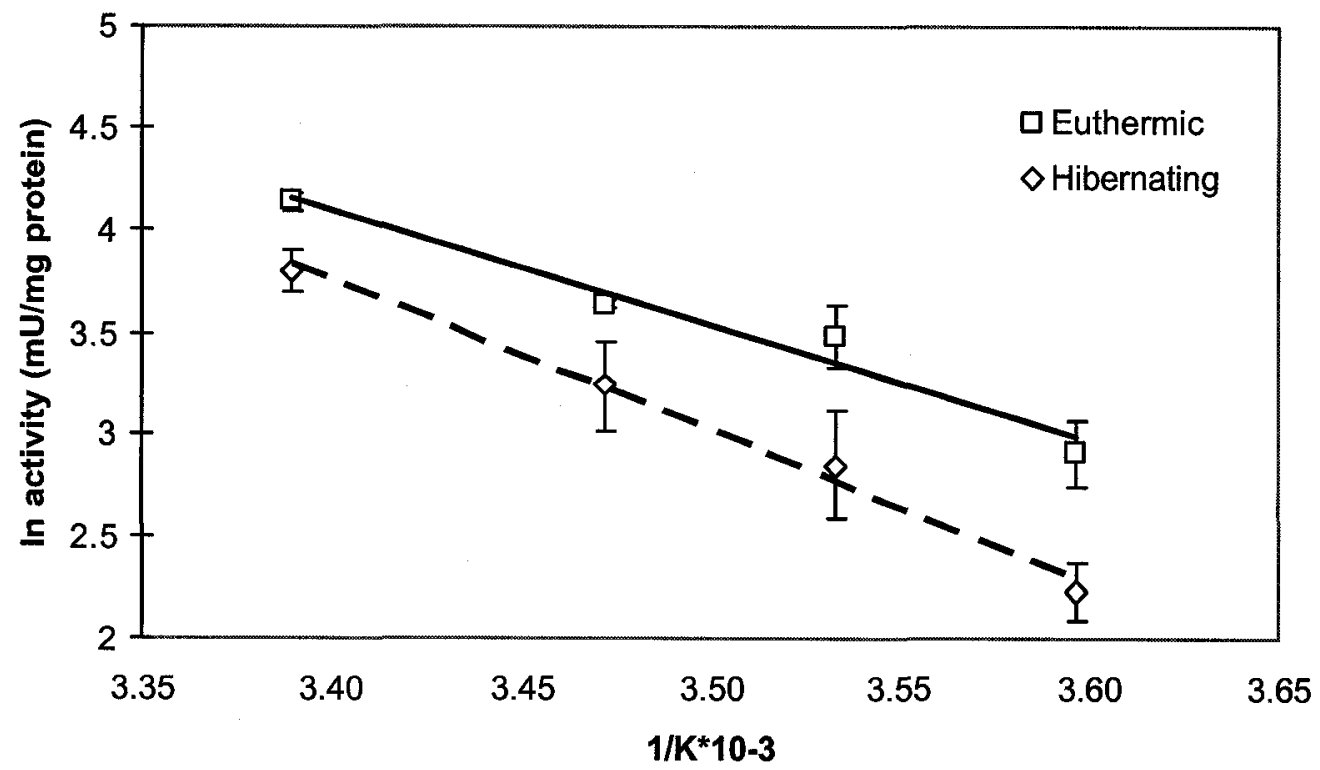

Reproduced with permission of the copyright owner. Further reproduction prohibited without permission. 
Figure 4-4. $\mathrm{S}_{0.5}$ values for skeletal muscle $\mathrm{AMPD}$ at different assay temperatures. Data are means $\pm S E M, n=4$ independent determinations on different preparations of enzyme from Richardson's ground squirrels. 
Figure 4-4

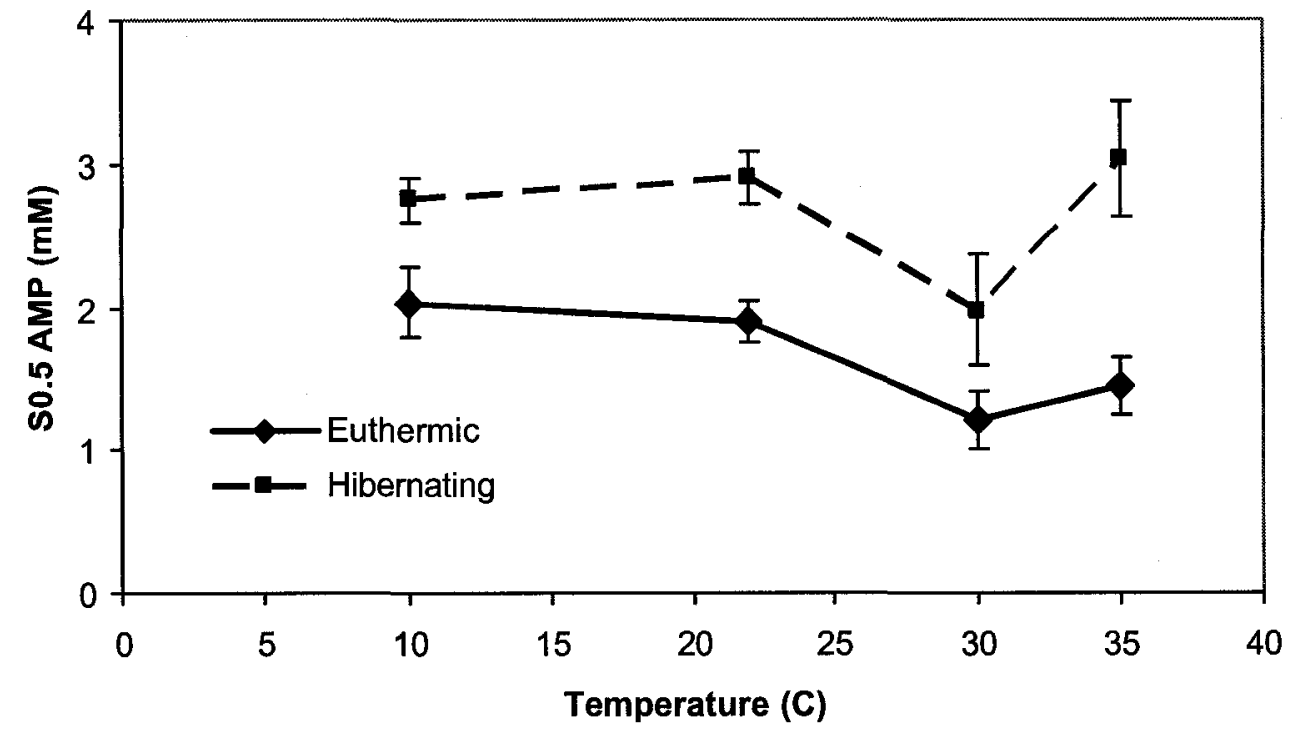


Figure 4-5. Effect of in vitro incubations of muscle extracts from Richardson's ground squirrels under conditions that promoted the action of protein phosphatases or protein kinases on AMPD. (A) Effect of stimulating endogenous protein phosphatases including total protein phosphatases (PPt), total Ser/Thr PPs (TST), PP1, PP2B or PP2C. Also shown is the effect of incubation with commercial alkaline phosphatase (AP). (B) Effect of stimulating endogenous protein kinases: PKA, PKC, PKG or AMPK. All incubations were at $22^{\circ} \mathrm{C}$ for $4 \mathrm{~h}$ under the conditions outlined in the Methods, followed by assay of AMPD maximal activity. Data are means $\pm S E M, n=6$ independent determinations on different preparations of enzyme. * - Significantly different from the corresponding euthermic control (no additions) activity using the Student's t-test, $\mathrm{P}<0.05 ;+$ significantly different from the corresponding hibernating control, $\mathrm{P}<0.05$. 
Figure 4-5.
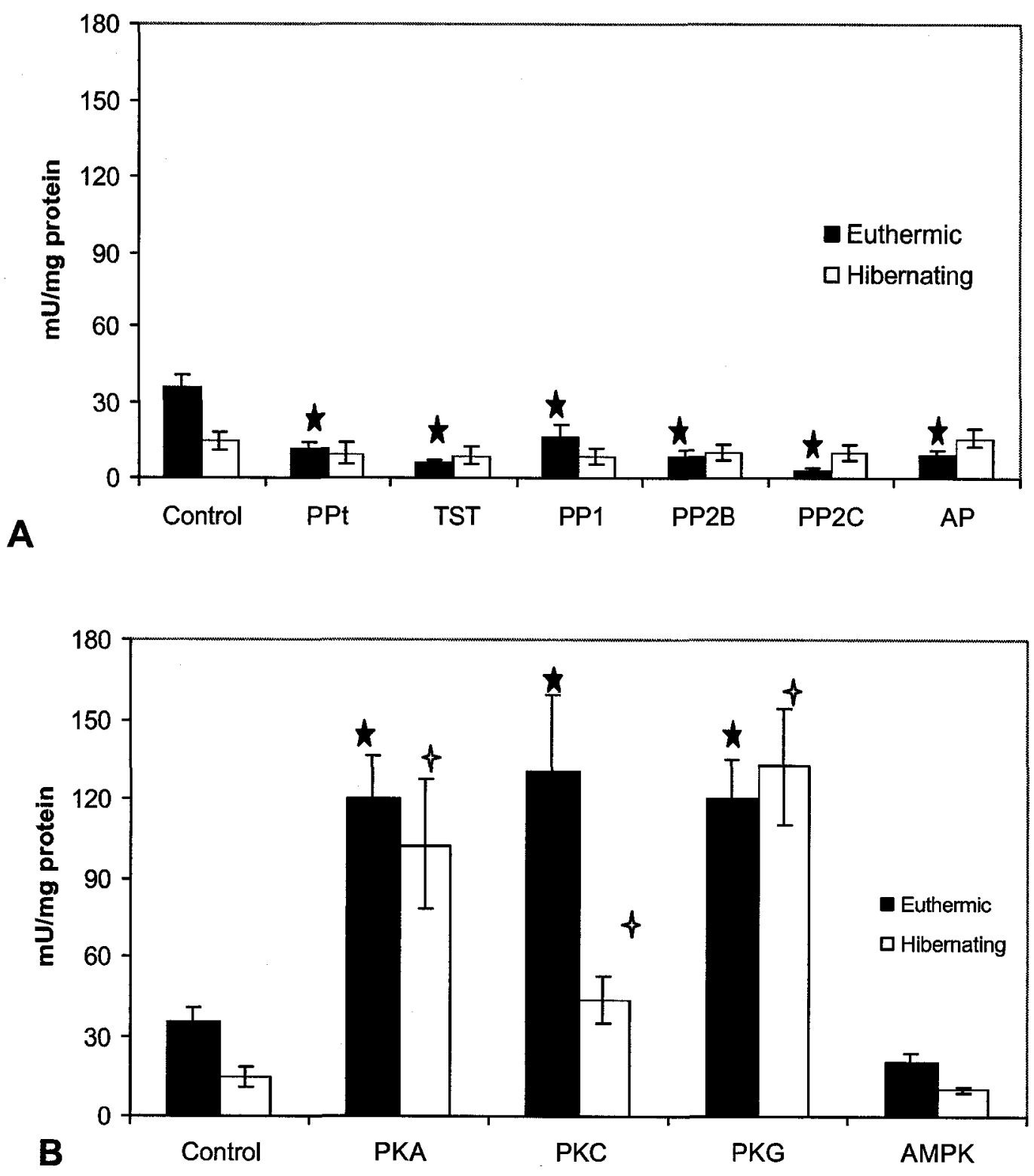
Figure 4-6. DEAE Sephadex ion exchange chromatography of skeletal muscle AMPD from Richardson's ground squirrels. (A) Elution patterns for AMPD from euthermic and hibernating squirrels. (B) Effects of incubation of euthermic extracts with alkaline phosphatase (AP) or stimulation of PKG in hibernating extracts on AMPD elution patterns. The column was equilibrated in $50 \mathrm{mM}$ Tris- $\mathrm{HCl}$ buffer $\mathrm{pH} 7.0$ containing 50 $\mathrm{mM} \beta$-GP, 1mM EDTA, 1mM EGTA, and $10 \mathrm{mM} \beta$-MeSH and developed using a 0-2 M $\mathrm{KCl}$ gradient in the same buffer. Data show representative profiles for single preparations but the same separations were achieved in multiple $(n=3)$ trials. 
Figure 4-6
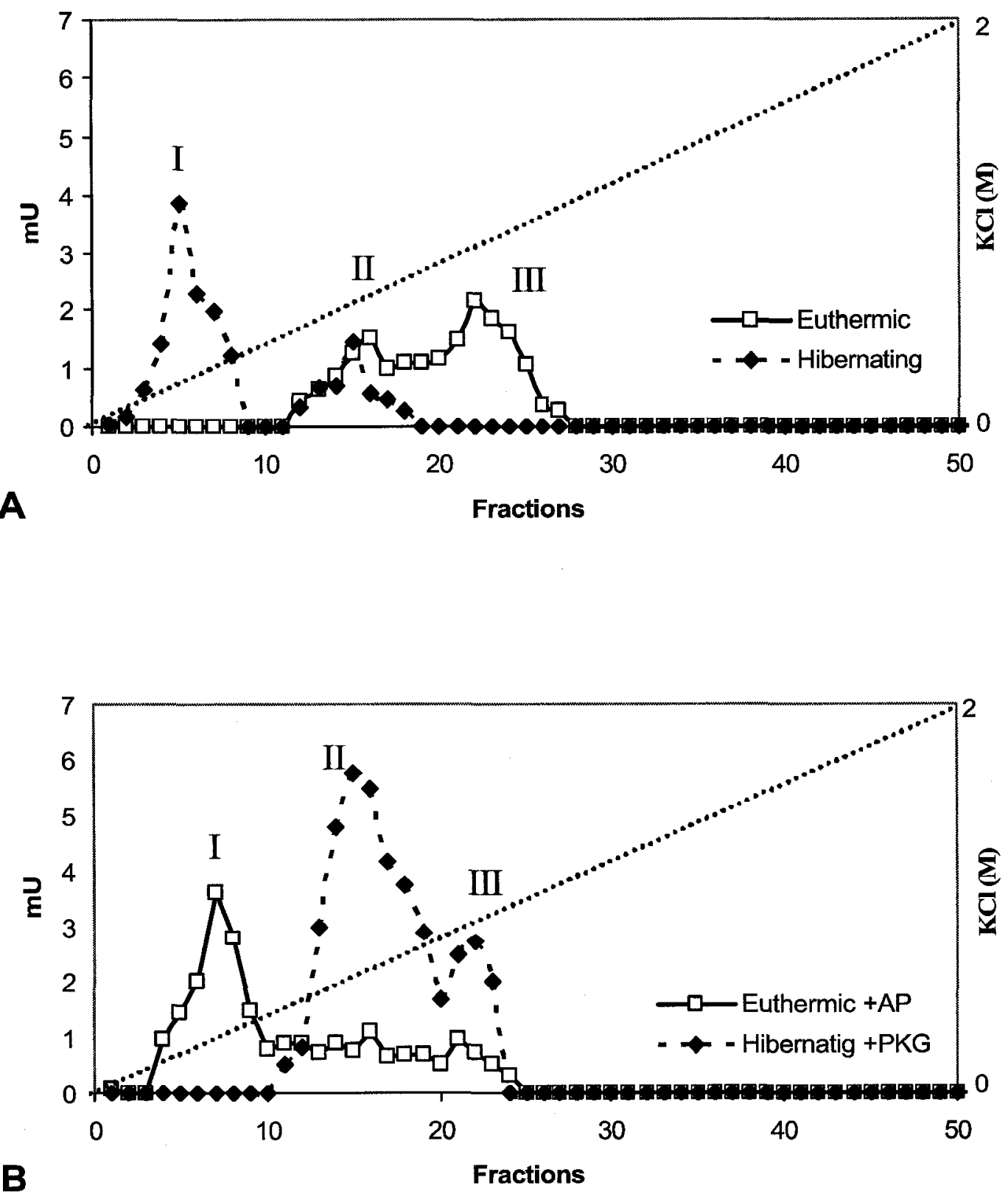


\section{Discussion}

Hibernation requires complex regulatory controls to address many issues including regulation of reversible entry into torpor, reprioritization of ATP expenditures and reorganization of metabolic fuel use for long term viability, integrated functioning of metabolism at body temperature more than 30 degrees Celcius below the norm for mammals, and differential expression of genes/proteins with specific protective functions in the torpid state. Research in recent years has documented a variety of regulatory mechanisms and changes in gene expression that are used to coordinate entry into and arousal from torpor and to maintain viability and cellular energetics during long term cold torpor (Storey, 2003; Storey and Storey, 2004). Although hibernators show a net reduction in the total adenylate pool of skeletal muscle during torpor, the ATP/ADP ratio and adenylate energy charge remain constant (Storey, 2003; English and Storey, 2000). AMPD is one of the enzymes involved in managing the adenylate pool size under stress conditions. The present research shows that AMPD from skeletal muscle of euthermic versus hibernating animals displays markedly different kinetic properties, shows differential responses to temperature and to effectors, and appears to be regulated by reversible protein phosphorylation.

Our data show that the maximal activity of skeletal muscle AMPD decreases during hibernation in both ground squirrel species, by 70 and $84 \%$ in RGS and TLGS, respectively. This suggests a reduced need for AMPD action in torpid animals which correlates with the fact that skeletal muscle is inactive for many days during each torpor bout. AMPD is undoubtedly involved in draining the adenylate pool as the animal sinks into torpor but the high enzyme activities needed to cope with burst muscle exercise in a 
euthermic animal are not apparently needed in torpor. The distribution of AMPD between free and bound fractions of muscle did not change during hibernation Furthermore, temperature change had little effect on $\mathrm{S}_{0.5}$ AMP of either euthermic or hibernating AMPD although we observed a $35 \%$ in the $\mathrm{S}_{0.5}$ for the enzyme from euthermic animals at higher temperatures (Fig. 4-4). $\mathrm{K}_{\mathrm{m}}$ AMP values for both prairie dog and rabbit muscle AMPD was also temperature independent (English and Storey, 2000). However, a number of enzyme kinetic parameters did change between euthermic and hibernating states. Apparent affinity for AMP substrate was reduced during hibernation in both species. $\mathrm{S}_{0.5}$ AMP was increased by about $35 \%$ during hibernation whereas muscle AMP levels decline by $\sim 50 \%$ (MacDonald and Storey, 1999), a situation that could again reduce AMPD activity in vivo during cold torpor. Sensitivity to ATP activation decreased during hibernation $\left(\mathrm{K}_{\mathrm{a}}\right.$ increased from 0.14 to $\left.0.24 \mathrm{mM}\right)$ and muscle ATP concentrations fall so the regulatory influence of ATP would be reduced in muscle during torpor. AMPD inhibition by ions also changed significantly with the enzyme from hibernating animals showing greater inhibition by $\mathrm{Mg}^{2+}$ but much reduced inhibition by $\mathrm{NH}_{4}^{+}$and $\mathrm{PO}_{4}{ }^{3-}$. $\mathrm{NH}_{4}{ }^{+}$is a product of AMPD whereas inorganic phosphate is a product of ATP hydrolysis. Although $\mathrm{I}_{50}$ values for both are well beyond physiological levels, the data suggest that integrated control of AMPD could combine responses to its product $\left(\mathrm{NH}_{4}{ }^{+}\right)$as well as a number of metabolites involved in energy metabolism $\left(\mathrm{PO}_{4}{ }^{3-}, \mathrm{ATP}\right.$ as well as ADP). Notably, sensitivity to these effectors $\left(\mathrm{ATP}, \mathrm{NH}_{4}{ }^{+}, \mathrm{PO}_{4}{ }^{3-}\right.$ ) is uniformly reduced during torpor. However, the significant changes in $\mathrm{S}_{0.5}, \mathrm{~K}_{\mathrm{a}}$ and $\mathrm{I}_{50}$ values, as well as the activation energy, during hibernation are important in another way for they all argue for a stable modification of the enzyme between euthermic and hibernating states. Reversible 
phosphorylation could be the method of this modification

Other authors have reported regulation of mammalian AMPD by reversible phosphorylation. Terjung (1998) reported that phosphorylation of AMPD could increase the activity of the enzyme. Moreover, Tovmasian et al. (1990) reported that protein kinase $\mathrm{C}$ effects on AMPD resulted in a 3-fold decrease in the $\mathrm{K}_{\mathrm{m}}$ value from 0.6 to 0.2 $\mathrm{mM}$. To assess phosphorylation control of muscle AMPD from a hibernating species, crude extracts of RGS muscle were incubated with different activators and inhibitors to stimulate the actions of specific protein kinases and protein phosphatases. We found that AMPD from euthermic versus hibernating animals responded differently to treatments with protein kinases and protein phosphatases and that the elution pattern of the enzyme on DEAE ion exchange chromatography was different between euthermic and hibernating states and changed in response to phosphatase or kinase treatments. These data are consistent with covalent modification of AMPD by reversible phosphorylation The activity of AMPD in euthermic muscle was reduced by $50-90 \%$ after treatments that stimulated dephosphorylation of the enzyme whereas AMPD activity from hibernating animals, which was already low, was unaffected by phosphatase treatments (Fig. 4-5a). This indicates that AMPD in hibernating animals is a low phosphate or dephosphorylated form and this also agrees with the data from DEAE chromatography that show that the hibernator enzyme eluted at a low salt concentration which is consistent with weak binding to the column by an enzyme with few or no covalently bound phosphate groups (Fig. 4-6a). On the other hand, both euthermic and hibernating AMPD showed a strong increase in activity when incubated under conditions that promoted the phosphorylation of the enzyme by PKA, PKC or PKG. However, the fold increase in AMPD activity was 
generally greater for protein kinase effects on the hibernating enzyme which is consistent with a lower original phosphate content of this enzyme. The elution pattern of euthermic AMPD also supports this conclusion and the dual peaks seen suggest that two phosphorylation states (medium and high) exist in euthermic extracts (Fig. 4-6a) which is also consistent with the response of euthermic AMPD activity to both phosphorylation and dephosphorylation treatments (Fig. 4-5a,b). These ideas are further supported by the effects of alkaline phosphatase treatment on euthermic AMPD which shifted the elution of the enzyme to a low salt concentration that corresponded with the elution position of untreated hibernator AMPD.

Analysis of $\mathrm{S}_{0.5}$ AMP values after incubation with different protein kinases or alkaline phosphatase showed that the incubation treatments produced significant changes in $\mathrm{S}_{0.5}$ (Table 4-1). Stimulation of any of the four protein kinases in hibernator extracts resulted in a significant decrease in $S_{0.5}$ to a value that was closer to the euthermic control $S_{0.5}$. Treatment with alkaline phosphatase did not alter the $S_{0.5}$ of the enzyme in hibernating animals but increased $\mathrm{S}_{0.5}$ of the euthermic enzyme to a level that was like the control hibernating situation. Both of these effects of protein kinases on hibernator AMPD and alkaline phosphatase on euthermic AMPD are consistent with the results in Figures 4-5 and 4-6. Overall, this indicates that the low phosphate form of the enzyme that occurs in hibernator extracts has low activity and low apparent affinity for AMP whereas the phosphorylated form in euthermic animals has higher activity and greater apparent affinity for AMP. The data for protein kinase effects on $\mathrm{S}_{0.5}$ AMP of euthermic AMPD (Table 4-1) also further support the idea that AMPD in resting euthermic muscle is in an intermediate stage of phosphorylation. Thus, specific incubations to stimulate 
protein kinases both increased activity compared with the euthermic control value (Fig. 4-5) and decreased the $S_{0.5}$ to a value significantly lower than the euthermic control (Table 4-1). The euthermic extracts used in the present study were from resting skeletal muscle. It is likely that there is metabolic scope to enhance AMPD action in working muscle; for example, it is well-known that the percentage of AMPD bound to myosin increases greatly during intense contraction and that binding changes enzyme activity and affinity for AMP (Ashby and Frieden, 1977, 1978, Bromberg, and Sahlin, 1984; Shiraki et al., 1979; Ichiro et al., 1998). Intense muscle work may also trigger enhanced phosphorylation of the enzyme to increase activity and substrate affinity under the physiological conditions (high rates of ATP hydrolysis during burst muscle work) where AMPD has its greatest role.

In conclusion, AMPD shows different kinetic parameters between hibernating and euthermic conditions in both TLGS and RGS. In both species AMPD activity and apparent affinity for its substrate is suppressed during hibernation. The data suggest that covalent phosphorylation of AMPD is responsible for this change. 
Chapter 5

\section{REGULATION OF AKT DURING HIBERNATION IN RICHARDSON'S GROUND SQUIRRELS}




\section{Introduction}

The serine/threonine protein kinase, Akt (also known as protein kinase B), generally mediates a variety of actions that can go forward when fuel/energy supplies to cells are plentiful while also inhibiting cell death signals. For example, Akt mediates the anabolic and growth-promoting effects of insulin and insulin-like growth factor (IGF) by actions that include activating the insulin-sensitive glucose transporter 4 to increase glucose uptake (Hill et al., 1999), promoting glycogen synthesis by inactivating glycogen synthase kinase 3 (GSK-3), facilitating lipogenesis from glucose at both transcriptional and enzymatic levels, and regulating multiple proteins that control ribosomal translation (Whiteman et al., 2002). Oppositely, Akt inhibits apoptosis by control of the proapoptotic protein $\mathrm{BAD}$ and regulates forkhead box, class $\mathrm{O}$ transcription factors that are involved in cell cycle arrest, quiescence, stress resistance, life extension and apoptosis in different systems (Greer and Brunet, 2005).

Akt is a member of the AGC (protein kinases A, G, and C) superfamily (Whiteman et al., 2002). The enzyme has three domains: an N-terminal pleckstrin homology $(\mathrm{PH})$ domain, a central catalytic domain, and a $\mathrm{C}$-terminal hydrophobic motif (HM). Stimulation of a membrane receptor (such as by insulin) activates phosphoinositide-3 kinase which generates phosphoinositide-3-phosphate that recruits inactive cytoplasmic Akt to the plasma membrane (via binding to the $\mathrm{PH}$ domain). Following membrane binding, Akt is activated by phosphorylation at two sites: Thr308 within the T loop of the catalytic domain and Ser473 in the HM, a noncatalytic region. Phosphorylation at Thr308 is catalyzed by phosphoinositide dependent kinase 1 (Alessi et 
al.., 1997). The identity of the kinase that phosphorylates Ser473 has been debated for many years but recent work indicates that it is an alternate form of mTOR (Sarbassov et al.., 2005, 2006).

Given the importance of Akt in integrating anabolic and catabolic responses in cells (Frost and Lang, 2007) we reasoned that this protein kinase could have a central role in regulating and reorganizing metabolism during hibernation. Clearly, growth stimuli should be inhibited in deep torpor but so should apoptosis since the goal in hibernation is stasis and life extension. How, then, does Akt work in hibernators? Previous studies used immunoblotting to assess changes in the total and phosphorylated contents of Akt in selected tissues of different hibernating species with variable results that generally indicated suppression of Akt activity during torpor (Lee et al., 2002; Eddy and Storey, 2003; Cai et al., 2004). The present study takes a different approach, conducting an enzymatic analysis of Akt from skeletal muscle and liver of ground squirrels to explore the activities, properties and regulation of the enzyme in euthermic and hibernating situations.

\section{Materials and Methods}

\section{Animals}

Richardson's ground squirrels, Spermophilus richardsonii, were held, hibernated and sampled as described in Chapter 2.

\section{Preparation of tissue extracts}

Samples of frozen liver or muscle were homogenized 1:5 w:v in extraction buffer 
[50 mM Tris, pH 7.5, $150 \mathrm{mM} \mathrm{NaCl}, 2 \mathrm{mM}$ EGTA, $30 \mathrm{mM} \mathrm{NaF}, 10 \mathrm{mM} \mathrm{Na} 4 \mathrm{P}_{2} \mathrm{O}_{7}, 100$

$\mu \mathrm{M} \mathrm{Na} \mathrm{VO}_{4}, 1 \%$ Triton $\mathrm{X}-100,50 \mathrm{mM} \beta$-glycerophosphate, $1 \mathrm{mM}$ dithiothreitol (DTT)]

with $10 \mu \mathrm{l}$ Sigma Phosphatase Inhibitor cocktail 1 (Cat. \# P285050) (for $1 \mathrm{ml}$ of extract), $2 \mu 1$ of Sigma Protease Inhibitor cocktail (Cat. \# P8340) (for $1 \mathrm{ml}$ of extract) and a few crystals of the protease inhibitor, phenylmethylsulfonyl fluoride (PMSF) added just prior to homogenization. Homogenates were centrifuged at $25,000 \mathrm{~g}$ for $30 \mathrm{~min}$ and then the supernatant was removed and stored on ice. Soluble protein concentrations were measured via the Coomassie Blue dye-binding method with the BioRad commercial reagent and then protein concentration in each extract was adjusted to $5 \mathrm{mg} / \mathrm{ml}$ using extraction buffer.

\section{Enzyme assay}

Akt activity was measured with a chelation-enhanced fluorophore, 8-hydroxy-5(N,N-dimethylsulfonamido)-2-methylquinoline (SOX), using the Omnia ${ }^{\mathrm{TM}} \mathrm{Akt}$ Fluorometric Assay (Invitrogen). Upon phosphorylation of the substrate peptide [AcARKRERAYSF-dPro-SOX-Gly-NH2; Aktide] by Akt, $\mathrm{Mg}^{2+}$ is chelated to form a bridge between the SOX moiety and the phosphate group that was added to a serine residue on the substrate, resulting in an increase in fluorescence (Shults et al., 2005). Optimal assay conditions were: $25 \mu \mathrm{g}$ protein, $40 \mathrm{mM}$ Tris, $\mathrm{pH} 7.5,15 \mathrm{mM} \mathrm{Mg}{ }^{2+}, 10 \mu \mathrm{M}$ peptide substrate, $1 \mathrm{mM}$ ATP, $200 \mu \mathrm{M}$ DTT, $4 \mu \mathrm{M}$ of protein kinase $\mathrm{C}$ (PKC) inhibitor, $0.4 \mu \mathrm{M}$ protein kinase A (PKA) inhibitor, $2 \mu \mathrm{M}$ GF109203X (inhibits GSK-3) and $2 \mu \mathrm{M}$ calmidazolium (inhibits calmodulin-dependent kinases). To measure the $\mathrm{K}_{\mathrm{m}}$ of Akt for its substrate, activities were measured over a range of peptide concentrations from 1 to 10 
$\mu \mathrm{M}$ using Corning 96-well half area solid white NBS microplates and a Victor fluorescence microplate reader (excitation at $355 \mathrm{~nm}$, emission at $460 \mathrm{~nm}$ ). Routine assays were conducted at $22^{\circ} \mathrm{C}$ but to assay activity at other temperatures, the microplate reader was placed in an adjustable temperature incubator and microplate well temperature was confirmed pre- and post-assay with a thermistor placed in a buffer- filled well.

\section{Dephosphorylation}

Muscle samples were homogenized 1:5 w:v in homogenization buffer $(50 \mathrm{mM}$ Tris, $\mathrm{pH} 7.5,150 \mathrm{mM} \mathrm{NaCl}, 1 \%$ Triton X-100, $1 \mathrm{mM}$ DTT) with $2 \mu 1$ of Sigma Protease Inhibitor cocktail (per $1 \mathrm{ml}$ of extract) and a few crystals of PMSF added just prior to homogenization. Homogenates were centrifuged at $25,000 \mathrm{~g}$ for $30 \mathrm{~min}$ and then the supernatant was incubated with $5 \mathrm{mM} \mathrm{MgCl}, 5 \mathrm{mM} \mathrm{CaCl}$ and $1 \mathrm{U}$ alkaline phosphatase $/ 100 \mu 1$ of homogenate (Sigma Cat. \# P7923) for $2.5 \mathrm{~h}$. Dephosphorylation was stopped by adding $2 \mathrm{mM}$ EGTA, $30 \mathrm{mM} \mathrm{NaF}, 10 \mathrm{mM} \mathrm{Na}_{4} \mathrm{P}_{2} \mathrm{O}_{7}, 100 \mu \mathrm{M} \mathrm{Na}_{3} \mathrm{VO}_{4}$, and $50 \mathrm{mM} \beta$-mercaptoethanol. Incubations were conducted such that final protein concentration in the stopped sample before assay was $5 \mathrm{mg} / \mathrm{ml}$.

\section{Ion exchange chromatography}

A $200 \mu 1$ aliquot of crude muscle extract prepared as described for standard assays and was applied to a column of DEAE-cellulose $(1.5 \mathrm{~cm} \times 5 \mathrm{~cm})$ equilibrated in extraction buffer (but with $\mathrm{pH}$ adjusted to 8.0). After washing to remove unbound protein from the column, enzyme activity was eluted with a linear $\mathrm{KCl}$ gradient $(0.75-1.25 \mathrm{M})$ in the same buffer. The activity in each $0.4 \mathrm{~mL}$ fraction was measured using the standard 
enzyme assay.

\section{Western blotting}

Western blotting was performed as described in Chapter 2 with the following changes. Electrophoresis was carried out at $160 \mathrm{~V}$ for 60 minutes. Proteins were transferred to polyvinylidene difluoride membranes at $160 \mathrm{~mA}$ for $1.5 \mathrm{~h}$. The membrane was blocked with $1 \%$ powdered skim milk dissolved in Tris-buffered saline with $0.5 \%$ Triton-X (TBST) for $30 \mathrm{~min}$ and then washed three times with TBST. The membrane was incubated with primary antibody raised against mammalian Akt (Akt rabbit polyclonal IgG; Cell Signalling, cat. \#9272) overnight at $4^{\circ} \mathrm{C}$. To assess the content of phosphorylated Akt the membrane was incubated with an antibody to phospho-Akt (Ser 473) (rabbit polyclonal IgG; Cell Signalling, cat. \#9271). After washing with TBST, the membrane was incubated with horseradish peroxidase-conjugated secondary antibody (mouse anti-rabbit IgG) for $2 \mathrm{~h}$. Bands were quantified using protocol that haalready been described in Chapter 2.

\section{Data, statistics and protein determination}

Data were analyzed as described in Chapter 2.

\section{Results}

\section{Kinetic analysis of ground squirrel muscle Akt}

Akt was analyzed with a newly developed methodology that uses a specific substrate peptide (Akt-tide) attached to 8-hydroxy-5-(N, N-dimethylsulfamido) 2- 
methylquinoline (Shults et al, 2005). Phosphorylation of the peptide by Akt in the presence of $\mathrm{Mg}^{2+}$ (as a chelator) results in the formation of a bridge between the Sox moiety and the phosphate group. This complex has enhanced fluorescence that can be quantified (excitation $355 \mathrm{~nm}$, emission $460 \mathrm{~nm}$ ). Not only does the assay use a substrate peptide that is specific to Akt but inhibitors of PKA, PKC, GSK-3 (GF109203X) and calmodulin-regulated kinases (calmidazolium) were also included in the assay to ensure that Akt was the only kinase being measured. In addition, the inclusion of phosphatase inhibitors (NaF, $\beta$-glycerophosphate, sodium pyrophosphate) prevented hydrolysis of the phospho-substrate after its formation Initial studies showed that the assays were linear over at least 50 minutes, the zero substrate blank was small, and the fluorescence increase was proportional to the concentration of substrate peptide.

Total activity of ground squirrel Akt was $60.3 \pm 5.2 \mathrm{nmol} / \mathrm{min} /$ gram wet weight (gww) in skeletal muscle from euthermic animals and decreased significantly by $60 \%$ $(\mathrm{P}<0.05)$ to just $24.1 \pm 4.9 \mathrm{nmol} / \mathrm{min} / \mathrm{gww}$ in skeletal muscle from hibernating animals. Figure 5-1 shows velocity versus substrate concentration curves for both ATP and peptide; the relationships were sigmoidal in both cases. All assays were done at a constant soluble protein concentration $(5 \mathrm{mg} / \mathrm{ml})$ so the figure also illustrates the differences in Akt maximal activity between euthermic and hibernating states as well as the effect of low assay temperature. Table 5-1 summarizes kinetic parameters for ground squirrel Akt and shows that the $\mathrm{S}_{0.5}$ values changed significantly during hibernation. Measured at $22^{\circ} \mathrm{C}$, the $\mathrm{S}_{0.5}$ value for Akt peptide decreased significantly by $28 \%$ during hibernation whereas the $\mathrm{S}_{0.5}$ ATP increased by $330 \%$. The velocity versus [substrate] relationships for both substrates were also substantially more sigmoidal (higher $\mathrm{n}_{\mathrm{H}}$ 
values) for the hibernator, compared with the euthermic, enzyme. Low assay temperature $\left(10^{\circ} \mathrm{C}\right)$ strongly affected the $\mathrm{S}_{0.5}$ ATP of the euthermic enzyme, increasing the value by $350 \%$; the Hill coefficient also rose by 2.4 -fold when the enzyme was assayed at $10^{\circ} \mathrm{C}$. However, due to very low activity, we were unable to measure $\mathrm{S}_{0.5}$ ATP for hibernator Akt at low temperature.

Akt activity was also assessed in ground squirrel liver and Figure 5-2 shows velocity versus [peptide] profiles for the enzyme from euthermic and hibernating animals. Akt activity in liver was $85.1 \pm 7.3 \mathrm{nmol} / \mathrm{min} / \mathrm{gram}$ wet weight (gww) in euthermic animals and decreased significantly by $66 \%(\mathrm{P}<0.05)$ to just $28.9 \pm 5.8 \mathrm{nmol} / \mathrm{min} / \mathrm{gww}$ in hibernating animals. However, the $\mathrm{S}_{0.5}$ value for peptide did not change between the two states (Table 5-1).

\section{Temperature effects on Akt}

To further characterize Akt from ground squirrel skeletal muscle, temperature effects on enzyme activity were measured over a range from 5 to $30^{\circ} \mathrm{C}$. Figure $5-3$ shows Arrhenius plots for the enzyme from muscle of euthermic and hibernating squirrels. Akt activity dropped off strongly at 30 and $35^{\circ} \mathrm{C}$. indicating denaturation of the protein but the relationship was linear over the range from $5-25^{\circ} \mathrm{C}$ for euthermic Akt and between $15-25^{\circ} \mathrm{C}$ for hibernator Akt. Calculated activation energies $\left(E_{\mathrm{a}}\right)$ were $58.1 \pm 7.1 \mathrm{~kJ} / \mathrm{mol}$ for euthermic Akt and $59.3 \pm 5.3 \mathrm{~kJ} / \mathrm{mol}$ for hibernator Akt (both $\mathrm{n}=3$; not significantly different). Sensitivity to urea denaturation can also characterize enzymes from two different physiological states and $\mathrm{I}_{50}$ values (inhibitor concentration that reduced activity by $50 \%$ ) were determined for muscle Akt from both conditions. I50 values were $3.51 \pm$ 
$0.26 \mathrm{M}( \pm \mathrm{SEM}, \mathrm{n}=3)$ for euthermic Akt and 2.99 $\pm 0.46 \mathrm{M}$ for hibernator Akt; these values were not significantly different.

\section{Western blotting}

Western blotting was applied to assess total Akt protein and phosphorylated (Ser473) Akt content (Figure 5-4). Total Akt protein in skeletal muscle did not change between euthermic and hibernating states. However, phospho-Akt content in muscle was $\sim 40 \%$ lower during hibernation compared with euthermia $(\mathrm{P}<0.05)$. In liver, phospho-Akt was readily detectable in euthermic animals but the antibodies detect a weak band for phospho-Akt in liver of hibernating ground squirrels. These data suggest that the decrease in Akt activity in hibernation, described above, is due to a decrease in the amount of phospho-Akt in this state.

\section{Dephosphorylation}

To further analyze this, we incubated extracts of skeletal muscle with alkaline phosphatase (AP) in vitro. As Figure 5-5 shows, AP treatment strongly reduced Akt activity (measured here as $\mathrm{pmol} / \mathrm{min} / \mathrm{mg}$ protein) in extracts of euthermic muscle by $75 \%$. AP also reduced Akt in hibernating extracts by $35 \%$, a lesser amount that is consistent with the already lower amount of phospho-Akt in hibernator muscle. Interestingly, remaining activity after AP treatment was equivalent in both euthermic and hibernating extracts suggesting full dephosphorylation of both forms. Figure 5-5 also shows liver Akt activity in extracts of euthermic and hibernating squirrels and this was very strongly reduced by $66 \%$ during hibernation, consistent with the failure to detect phospho-Akt in hibernator liver (Figure 5-4). 


\section{Ion exchange chromatography of Akt}

Ion exchange chromatography is often used to separate isozymes and differentially phosphorylated forms of enzymes. DEAE-cellulose chromatography was used to analyze ground squirrel skeletal muscle Akt from euthermic versus hibernating animals. Figure 5-6 shows that Akt from euthermic muscle eluted in three peaks, whereas the enzyme in extracts from hibernating animals showed only two peaks of activity, peak III (eluting at the highest salt concentration) being absent. These three peaks probably represent the three known Akt isozymes (Akt1, Akt2, Akt3). Hence, in muscle of hibernating squirrels, one isozyme of Akt was completely dephosphorylated and showed no activity whereas the other two isozymes showed a strongly reduced content of active phosphorylated enzyme. Akt activity in peaks I and II was also strongly reduced in extracts from hibernating muscle compared with euthermic extracts, again consistent with the reduced activity in hibernation reported above. 
Table 5-1. $\mathrm{S}_{0.5}$ values for substrates of skeletal muscle and liver Akt from euthermic and hibernating Richardson's ground squirrels. The effect of treatment with alkaline phosphatase (AP) on Akt peptide apparent affinity is also shown. Assays were conducted at $22^{\circ} \mathrm{C}$, or $10^{\circ} \mathrm{C}$ where indicated; $\mathrm{n}_{\mathrm{H}}$ is the Hill coefficient. Data are means $\pm \mathrm{SEM}, \mathrm{n}=$ 3. a - Significantly different from the corresponding untreated euthermic value, using the Student's t-test, $\mathrm{P}<0.05$. N.D. - not determined because measurable activity was too low.

\begin{tabular}{|c|c|c|c|c|}
\hline \multirow[b]{3}{*}{ Muscle } & \multicolumn{2}{|c|}{ Euthermic } & \multicolumn{2}{|l|}{ Hibernating } \\
\hline & $\mathrm{S}_{0.5}, \mu \mathrm{M}$ & $\mathrm{n}_{\mathrm{H}}$ & $\mathrm{S}_{0.5}, \mu \mathrm{M}$ & $\mathrm{n}_{\mathrm{H}}$ \\
\hline & & & & \\
\hline Akt peptide & $3.38 \pm 0.18$ & $2.97 \pm 0.35$ & $2.43 \pm 0.04^{\mathrm{a}}$ & $4.98 \pm 0.96^{\mathrm{a}}$ \\
\hline ATP & $382.0 \pm 45.6$ & $1.80 \pm 0.33$ & $1261 \pm 110^{\mathrm{a}}$ & $2.43 \pm 0.32$ \\
\hline ATP (at $10^{\circ} \mathrm{C}$ ) & $1342 \pm 148$ & $4.28 \pm 0.98$ & N.D. & \\
\hline Liver & & & & \\
\hline Akt peptide & $2.40 \pm 0.1$ & $4.90 \pm 0.51$ & $2.21 \pm 0.21$ & $2.49 \pm 0.57^{\mathrm{a}}$ \\
\hline
\end{tabular}


Figure 5-1. Activity versus substrate concentration relationships for ground squirrel muscle Akt. A: Effect of variation in ATP concentration. B: Effect of variation in Akt substrate peptide concentration. Data are units/mg protein, mean $\pm S E M, n=3$ independent determinations on different preparations of enzyme. 
Figure 5-1
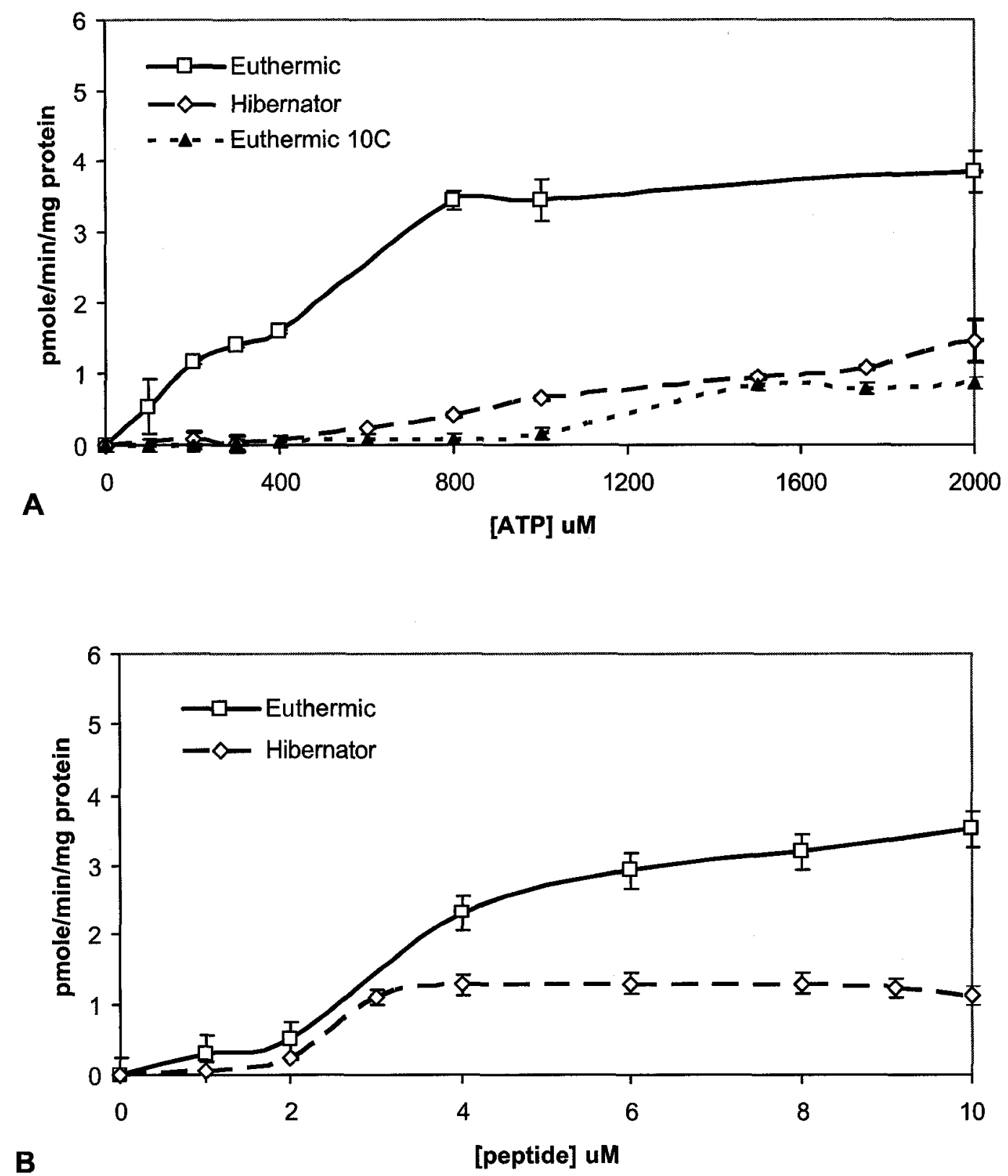
Figure 5-2. Activity versus fluorescent peptide substrate concentration for Akt from liver of euthermic versus hibernating ground squirrels. Data are units/mg protein, mean \pm $\mathrm{SEM}, \mathrm{n}=3$ independent determinations on different preparations of enzyme. 
Figure 5-2.

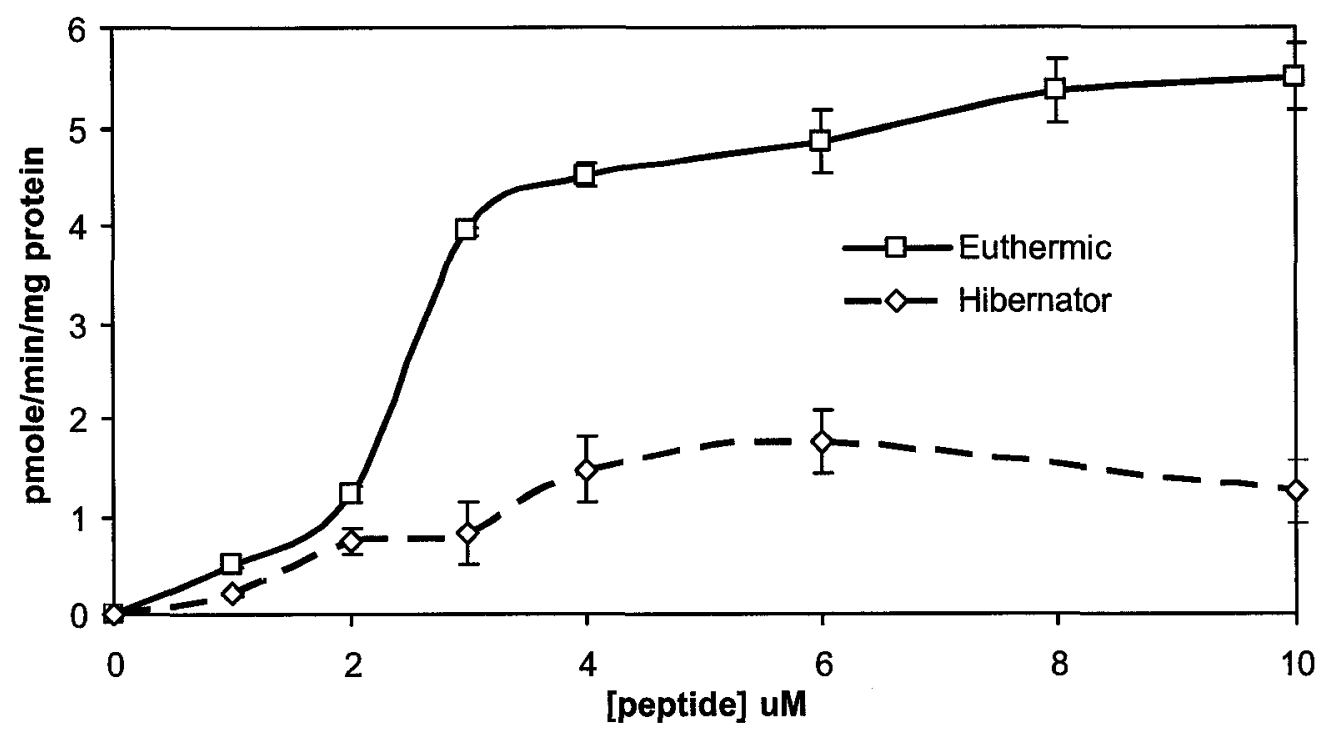


Figure 5-3. Effect of temperature on Akt from skeletal muscle of euthermic and hibernating ground squirrels shown as Arrhenius plots. Data are means $\pm S E M, n=3$ independent determinations on different preparations of enzyme. 
Figure 5-3.

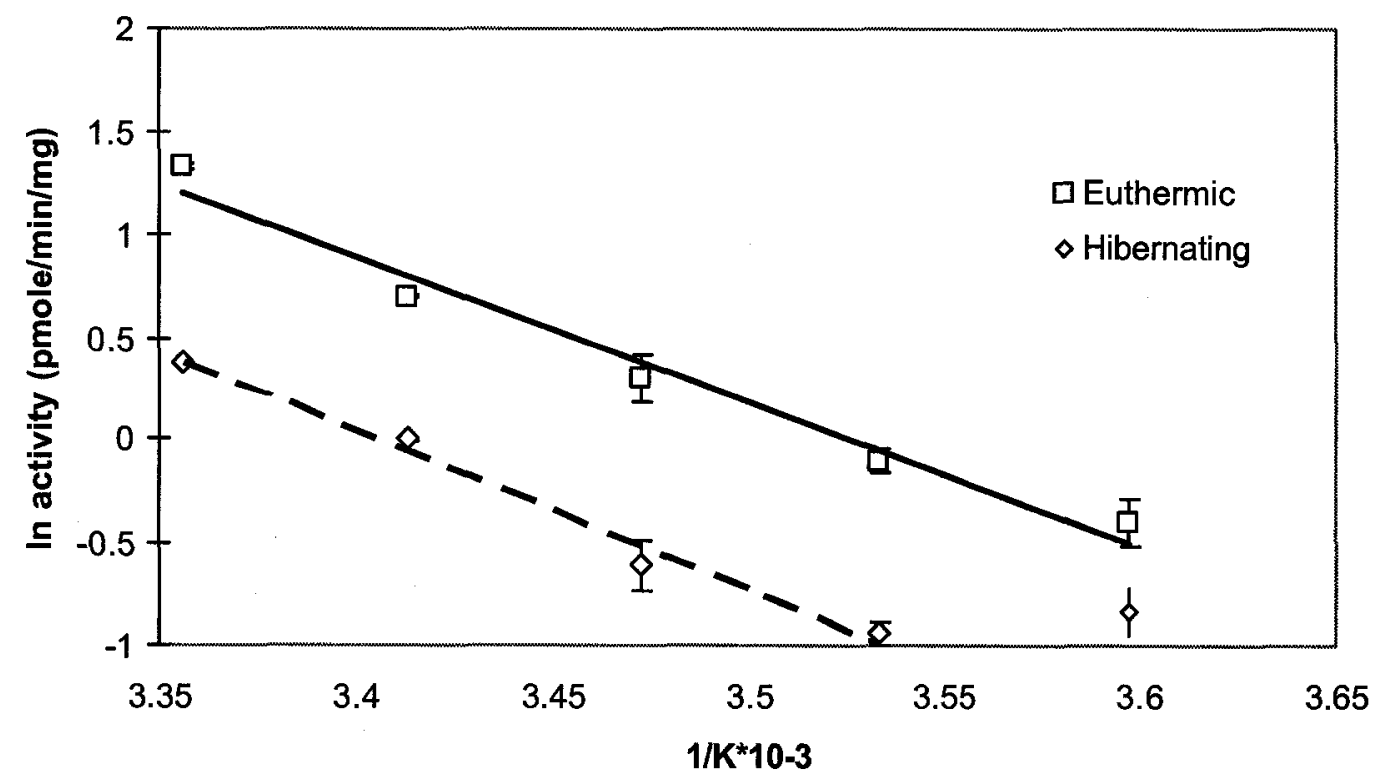


Figure 5-4. Effect of hibernation on total and phosphorylated levels of Akt in muscle and liver of Richardson's ground squirrels. Antibodies detected a dominant band at $60 \mathrm{kDa}$ that was determined to be Akt. Mean \pm SEM values for normalized band intensities were calculated from $n=5$ trials for euthermic and hibernating samples, followed by significance testing using the Student's t-test; * significantly different from the euthermic value, $\mathrm{P}<0.05$. 
Figure 5-4.
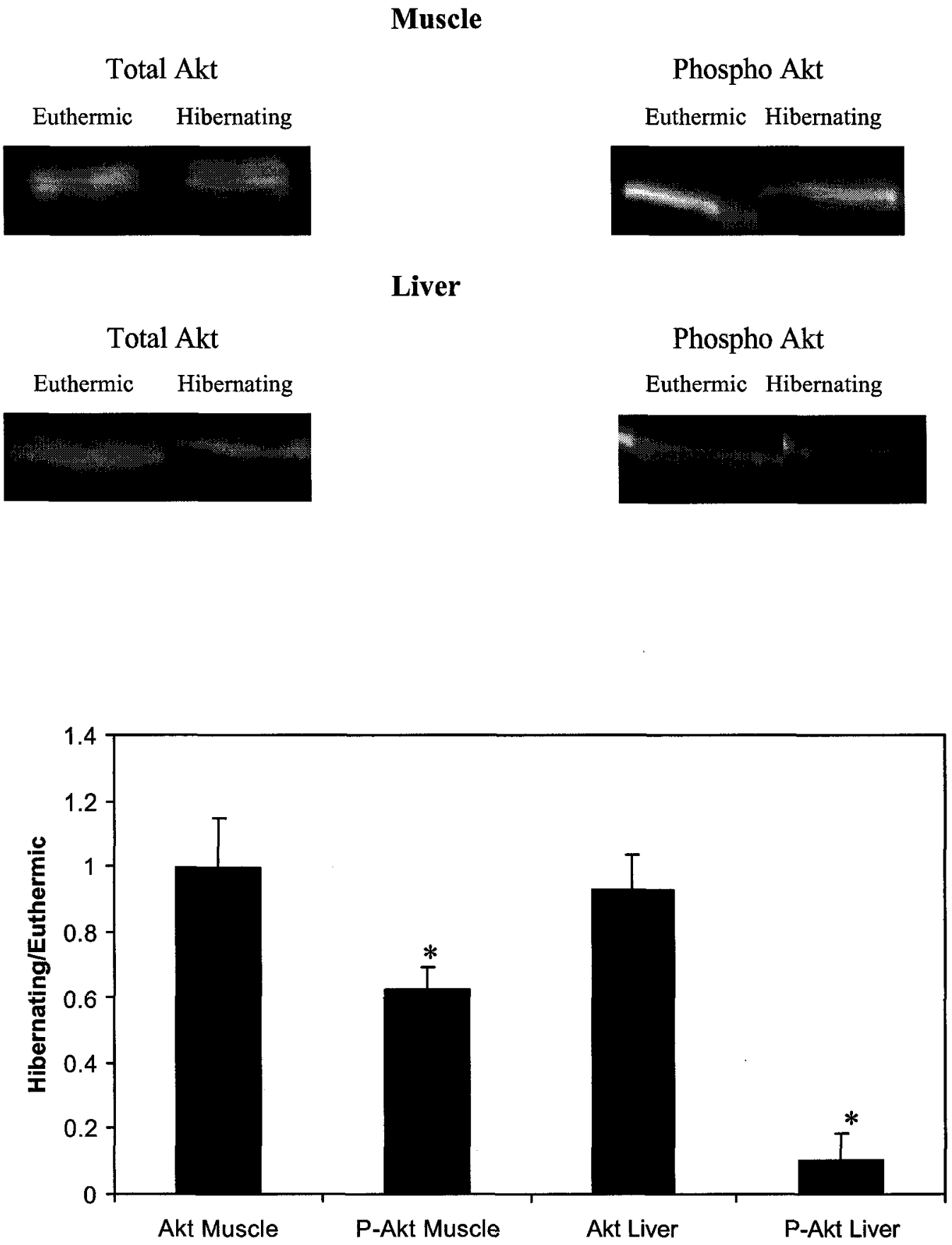
Figure 5-5. Akt activity in liver and skeletal muscle squirrel of euthermic and hibernating ground squirrels and the effect of alkaline phosphatase (AP) treatment on muscle Akt activity. *-Significantly different from the comparable value for euthermic animals $(\mathrm{P}<0.05)$. Data are units $/ \mathrm{mg}$ protein, mean $\pm \mathrm{SEM}, \mathrm{n}=3$ independent determinations on different preparations of enzyme. ${ }^{a}$ - Significantly different from euthermic Akt; ${ }^{b}$ significantly different from the corresponding untreated muscle enzyme $(\mathrm{P}<0.05)$. 


\section{Figure 5-5}

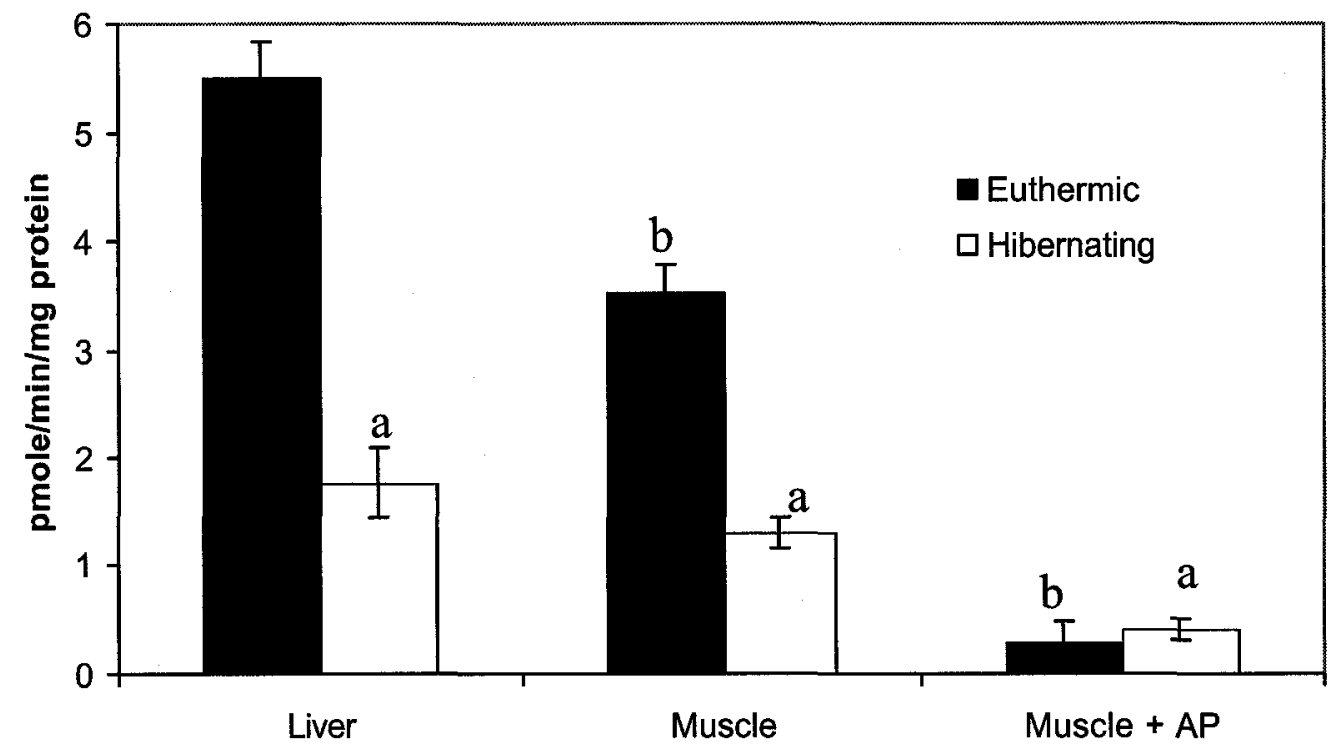


Figure 5-6. DEAE Sephadex ion exchange chromatography of ground squirrel skeletal muscle Akt. The column was developed using a linear $\mathrm{KCl}$ gradient $(0.75-1.25 \mathrm{M})$ in extraction buffer (adjusted to $\mathrm{pH} 8.0$ ). 
Figure 5-6.

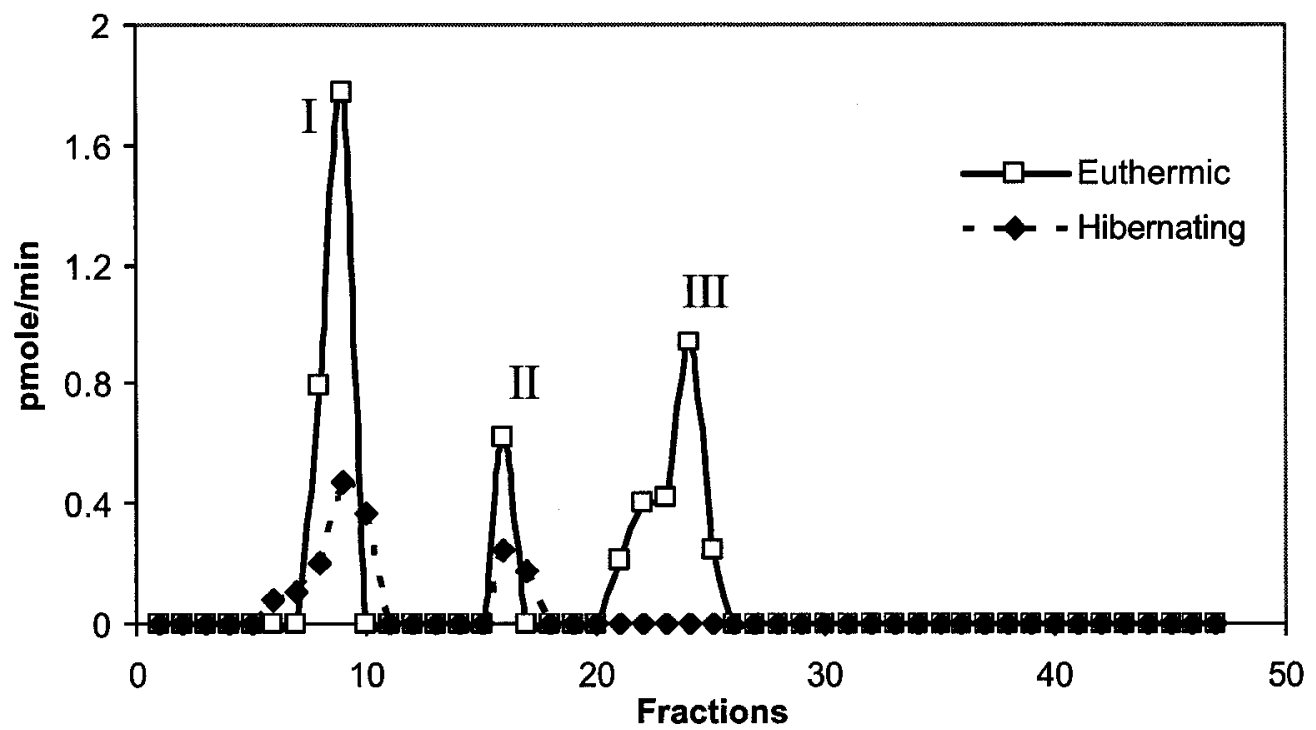




\section{Discussion}

Akt plays a central role in the regulation of intermediary metabolism, integrating anabolic and catabolic demands. By transducing multiple growth factor and cytokine signals, the activation of Akt stimulates skeletal muscle hypertrophy and antagonizes the loss of muscle protein in apoptosis (Frost and Lang, 2007). We wondered, then, how Akt would respond during hibernation, a situation where the normal antagonism between growth/anabolism and apoptosis breaks down and both processes must be suppressed to achieve long term viability in an energy-restricted torpid state. Indeed, the action of Akt in apoptosis control may be particularly important since hibernating animals show very low skeletal muscle atrophy over weeks/months of inactivity (Rourke et al., 2004; Rourke et al., 2006; Shavlakadze and Grounds, 2006) conditions that would cause a major loss of muscle mass in nonhibernating species, including man

The present study is the first to investigate the enzymatic properties of Akt from a hibernating species to determine whether kinetic or regulatory controls on Akt may contribute to managing this important signalling enzyme under euthermic versus torpid and/or high versus low body temperature states. The activity state of Akt has been assessed previously in some hibernating species with variable results. Hoehn et al. (2004) found seasonal changes in the activity and protein levels of Akt in white adipose and skeletal muscle of marmots (Marmota flaviventris) over the summer/autumn that correlated with the pre-hibernation storage of fuel reserves. Eddy and Storey (2003) found no change in total Akt and phospho-Akt (Ser473) in skeletal muscle of euthermic versus hibernating little brown bats (Myotis lucifugus) but phospho-Akt decreased by 
$60 \%$ in liver during torpor. Lee et al. (2002) found a 3-fold activation of Akt in brain of a temperate bat (Rhinolpopus ferrumequinum) during the period of high intensity oxygen consumption and thermogenesis accompanying interbout arousal; this implied a prior suppression of Akt during torpor. Finally, Cai et al. (2004) documented an approximate $50 \%$ decrease in phospho-Akt in brain and skeletal muscle in 13-lined ground squirrels (Spermophilus tridecemlineatus) during hibernation.

Our findings for Richardson's ground squirrels (S. richardsonii) are comparable. Total Akt protein content in skeletal muscle did not change during hibernation but phospho-Akt (Ser473) content decreased by $40 \%$ (Figure 5-4). The same was true in $S$. richardsonii liver; phospho-Akt (Ser473) was detected in substantial amounts during euthermia but was apparently absent in torpid animals. Measurements of Akt activity agreed with the immunoblotting data; muscle Akt activity in S. richardsonii was reduced by $60 \%$ during hibernation and liver activity declined by $\sim 66 \%$. Alkaline phosphatase treatment of muscle Akt confirmed these findings by showing that dephosphorylation treatment suppressed Akt activity much more strongly in extracts from euthermic muscle (Figure 5-5), indicating a greater amount of the active, phosphorylated enzyme in muscle from euthermic versus hibernating animals. The natural mechanism of Akt inactivation in vivo during hibernation is yet to be established. Current data on mammalian Akt implicates two different phosphatases acting on the two main phosphorylation sites. PP2A preferentially dephosphorylates $\mathrm{P}-\mathrm{Thr} 308$ whereas a $\mathrm{PH}$ domain leucine-rich repeat protein phosphatase (PHLPP) belonging to the PP2C family appears to act on PSer473 (Bayascas and Alessi, 2005).

Both reduced Akt activity and reduced phospho-Akt (Ser473) content indicate 
that Akt signalling is reduced in muscle and liver of torpid ground squirrels. This infers that multiple Akt-regulated anabolic processes would also be suppressed in concert during hibernation. This is certainly true when protein synthesis has been evaluated. Akt is known to modulate protein synthesis in skeletal muscle and fat cells by stimulating the initiation and elongation steps in protein translation in response to signals from insulin or IGF (Shah et al., 2000; Gingras et al., 2001). However, in hibernation, the observed changes in the phosphorylation state of multiple ribosomal initiation and elongation factors and/or their associated binding proteins, as well as the dissociation of polysomes, are all consistent with strong suppression of net protein synthesis during torpor (Frerichs et al., 1998; Van Breukelen et al., 2004; Hittel and Storey, 2002a; Knight et al., 2000). These are all changes that are expected from a suppression of Akt function. Glycogen synthesis and lipogenesis are also strongly suppressed during hibernation since the animals do not eat over the winter months; again, this is consistent with suppressed Akt function in hibernation. Indeed, hibernators switch to an almost total reliance on lipid catabolism and enzymes/proteins related to lipolysis are some of the few genes/proteins that are up-regulated in torpor (Hittel and Storey, 2002b; Andrews, 2004).

Not only was Akt activity reduced during hibernation, but the kinetic properties of the enzyme also changed significantly. Skeletal muscle Akt from hibernating animals showed a significant reduction in $\mathrm{S}_{0.5}$ for its substrate peptide (by $28 \%$ ) and the enzyme from both organs showed changes in the sigmoidicity of the velocity versus [peptide] reaction, changes that could alter the activity of Akt towards its protein substrates in the cold torpid state. Muscle Akt also showed a very large increase (3.3-fold) in $\mathrm{S}_{0.5}$ for ATP as compared with the enzyme from euthermic muscle. The $\mathrm{S}_{0.5}$ ATP for euthermic Akt 
also increased by a comparable amount (3.5-fold) when Akt was assayed at low temperature $\left(10^{\circ} \mathrm{C}\right)$, not unlike the core $\mathrm{Tb}$ of hibernating squirrels. These strong effects of low temperature and hibernating state on ATP apparent affinity could be very significant for enzyme function in vivo during cold torpor. Thus, not only does Akt show much lower apparent affinity for ATP when assayed in the cold or sampled from a torpid animal but the adenylate content of hibernator organs is also reduced during torpor. Total adenylate levels in skeletal muscle of both ground squirrels and prairie dogs fell by about $30 \%$ during torpor although adenylate energy charge was maintained (MacDonald and Storey, 1999; English and Storey, 2000). Reduced apparent affinity for ATP coupled with lower availability of ATP substrate means that Akt activity in vivo under conditions of cold torpor could be compromised from a kinetic point of view. This could create a reduced enzymatic potential for ATP-dependent phosphorylation of Akt targets during torpor in addition to the overall reduction in the amount of active phosphorylated Akt present in muscle during hibernation.

Akt substrate apparent affinity parameters changed significantly between euthermic and hibernating states but two parame ters that assessed enzyme physical properties indicated that the enzyme retained similar structural stability in the two states. Thus, Akt in both states showed similarly high resistance to urea inhibition of activity with $\mathrm{I}_{50}$ values of about $3 \mathrm{M}$. Temperature effects on Akt activity were also the same between euthermic and hibernating states with calculated activation energies from Arrhenius plots were $58-59 \mathrm{~kJ} / \mathrm{mol}$ in both cases.

Ion exchange chromatography was used to determine if multiple forms of Akt were present in ground squirrel muscle. This analysis found three peaks of Akt activity in 
euthermic muscle (Figure 5-6) which is consistent with results for other mammals. Akt1 and Akt2 are predominantly expressed in skeletal muscle, thymus, brain, heart and lung, whereas expression of Akt3 dominates in the brain and testes (Nader, 2005). Similarly, Figure 5-6 shows two major peaks in euthermic muscle and one smaller peak. However, during hibernation, activity in peaks I and II decreased substantially whereas peak III activity disappeared entirely. This indicates differential regulation of the Akt isozymes and, therefore, the potential for differential regulation during hibernation of downstream targets that are under the control of the different Akt isozymes.

In conclusion, Akt activity and phosphorylation state were strongly suppressed in both muscle and liver during hibernation in ground squirrels. Given that Akt transduces a variety of anabolic signals such as from insulin and IGF, suppressed activity of Akt in the organs of torpid animals is consistent with suppression and/or arrest of biosynthetic and growth processes during hypometabolism. However, suppressed activity of Akt during torpor would argue against a major role for Akt in anti-apoptosis control so other signal transduction mechanisms must be sought as mediators for atrophy inhibition during hibernation. Analysis of muscle Akt enzymatic activity also revealed mechanisms for the kinetic control of the enzyme during hibernation. Enzyme apparent affinity for substrates (peptide, ATP) differed significantly between euthermic and hibernating states. This was particularly prominent for ATP, skeletal muscle Akt showing a large reduction in apparent affinity for ATP (increase in $\mathrm{K}_{\mathrm{m}}$ ATP) during hibernation and also as a consequence of low temperature assay. Under metabolic conditions of reduced ATP availability in hibernator muscle, this would contribute to limiting Akt activity in the cold torpid state. 
Chapter 6

REGULATION OF MAPKAP-K2 IN RICHARDSON'S

GROUND SQUIRRELS, SPERMOPHILUS RICHARDSONII, DURING HIBERNATION 


\section{Introduction}

The p38 mitogen activated protein kinase (MAPK) has a major role in transducing and mediating cell responses to environmental stresses. One of the downstream targets that is directly phosphorylated by $\mathrm{p} 38$ is the MAPK-activated protein kinase-2 (MAPKAP-K2; EC 2.7.11.1) (Hitti et al, 2006). MAPKAP-K2 is involved in the posttranslational regulation of genes that have an adenylate/uridylate-rich element (ARE) in the $3^{\prime}$-untranslated region (3'-UTR) of their mRNA. About $8 \%$ of the genes in the human genome contain AREs, totaling several hundred mRNA transcripts (Bakheet et al, 2001).

In resting cells, MAPKAP-K2 is found in the nucleus. After phosphorylation and activation of $\mathrm{p} 38$, this kinase binds to a basic docking motif in the $\mathrm{C}$ terminus of MAPKAP-K2, and phosphorylates key regulatory sites on it. MAPKAP-K2 and $\mathrm{p} 38$ form a complex in the nucleus which can then phosphorylate a variety of transcription factors including CREB/ATF1, MEF2, CHOP, ATF2, E47 and ER81. Phosphorylation of MAPKAP-K2 also unmasks the nuclear export signal (NES) in its C-terminal which is a prerequisite for transport of MAPKAP-K2 into the cytoplasm. Once there, MAPKAP-K2 can phosphorylate a number of cytoplasmic proteins including glycogen synthase, the small heat shock protein Hsp25/27, tyrosine hydroxylase, 5-lipoxygenase and leukocytespecific protein 1 (Kotlyarov and Gaestel, 2002; Kotlyarov et al 2002). Known actions of MAPKAP-K2 include a role in the inflammatory response with regulatory effects on the expression of cytokines such as tumour necrosis factor- $\alpha$ (TNF $\alpha)$ and interleukin 6 (IL-6) that seem to involve increasing mRNA stability and translation (Neininger et al., 2002; 
Kotlyarov and Gaestel, 2002). Indeed, the link is quite well established in the case of proinflammatory stimuli that activate cyclooxygenase $2(\mathrm{COX} 2)$ gene expression (Lasa et al., 2000); stabilization of COX2 mRNA via protein binding to an ARE in the 3'-UTR appears to involve p38 activation, MAPKAP-K2 activation, and phosphorylation of Hsp27.

The activities of many cellular enzymes are suppressed during torpor by reversible protein phosphorylation and fuel use is altered to place a primary dependence on lipid and ketone catabolism. All of these adjustments are mediated at the cellular level by the actions of signal transduction pathways involving a variety of protein kinases. Several studies have documented changes in p38 MAPK signalling during hibernation (Zhu et al., 2005; MacDonald and Storey, 2005; Eddy and Storey, 2007). Hence, we hypothesized that MAPKAP-K2 would also be modulated during hibernation In the present study we were particularly interested in the enzymatic properties of ground squirrel MAPKAP-K2 and we report hibernation-responsive changes in the kinetic parameters, phosphorylation state and stability of skeletal muscle MAPKAP-K2 that would alter enzyme function during cold torpor.

\section{Materials and Methods}

\section{Animals}

Animal collection, holding, feeding and conduct of hibernation experiments were as described in detail previously for Richardson's ground squirrels by MacDonald and Storey (2005) and in Chapter 2. 


\section{Preparation of tissue extracts and enzyme analysis}

Samples of skeletal muscle were prepared as described in Chapter 5. Activity of MAPKAP-K2 in ground squirrel muscle was measured using the $\mathrm{Omnia}^{\mathrm{TM}}$ kinase activity assay, essentially as described in Chapter 5, but using a specific substrate for MAPKAP-K2. The substrate was AcAHLQRQLSI-dPro-SOX-Gly-NH ${ }_{2}$ (the underlined portion shows the enzyme-specific peptide, MK2tide) (Shults et al., 2005).. Other procedures including incubations with alkaline phosphatase to dephosphorylate the enzyme and DEAE ion exchange chromatograph were also conducted as described fro Akt in Chapter 5. Data were analyzed as described in Chapter 2.

\section{Western blotting and pulse proteolysis}

Western blotting was performed as described in Chapter 2 with the following changes. Electrophoresis was carried out at $120 \mathrm{~V}$ for $80 \mathrm{~min}$ at $160 \mathrm{~V}$. Proteins were transferred to polyvinylidene difluoride membranes (PVDF) at $160 \mathrm{~mA}$ for $1.5 \mathrm{~h}$. The membrane was blocked with $1 \%$ powdered skim milk dissolved in Tris-buffered saline with $0.5 \%$ Triton-X (TBST) for $30 \mathrm{~min}$ and then washed three times with TBST. The membrane was incubated with primary polyclonal antibody raised against MAPKAP-K2 in rabbits (Santa Cruz, Cat\# 7871) overnight at $4^{\circ} \mathrm{C}$. After washing with TBST, the membrane was incubated with HRP-conjugated secondary antibody (mouse anti-rabbit IgG) for $2 \mathrm{~h}$ and then washed. Immunoreactive bands were visualized and quantified as described in Chapter 2.

Pulse proteolysis was performed as described in Chapter 2. Each sample was then subjected to Western blotting as described above to measure the amount of folded MAPKAP-K2 protein remaining. 


\section{Results}

\section{Kinetic analysis of ground squirrel muscle MAPKAP-K2}

The conduct of MAPKAP-K2 assays was essentially as described for Akt in the Results section of Chapter 5 including the inclusion of inhibitors or protein kinases and phosphatases to ensure specificity for MAPKAP-K2 and initial assessment of reaction blanks, linearity over time, and dependence of fluorescence increase on substrate concentration

Figure 6-1 shows velocity versus substrate concentration curves for muscle MAPKAP-K2. The enzyme from euthermic muscle showed a near hyperbolic relationship with respect to $[\mathrm{ATP}]$ concentration when assayed at either $22^{\circ}$ or $10^{\circ} \mathrm{C}$. The $\mathrm{S}_{0.5}$ value for ATP was $184 \pm 10.2 \mu \mathrm{M}$ at $22^{\circ} \mathrm{C}$ and inc reased significantly by $28 \%$ at $10^{\circ} \mathrm{C}$ (Table 6-1). The $\mathrm{S}_{0.5}$ for peptide of euthermic MAPKAP-K2 increased $25 \%$ at $10^{\circ} \mathrm{C}$ as compared to $22^{\circ} \mathrm{C}$ and $\mathrm{n}_{\mathrm{H}}$ value for peptide were less sigmoidal at $10^{\circ} \mathrm{C}(\mathrm{P}<0.05)$. Analysis of the enzyme from muscle of hibernating ground squirrels showed significant changes in the $\mathrm{S}_{0.5}$ values for both substrates at $22^{\circ} \mathrm{C}$ as compared with euthermic values; $S_{0.5}$ ATP doubled whereas the $S_{0.5}$ peptide decreased by 16\% (Table 6-1, Fig. 6-1). Low temperature assay resulted in an increase of $38 \%$ in $\mathrm{S}_{0.5}$ peptide of hibernator MAPKAP$\mathrm{K} 2$ whereas $\mathrm{S}_{0.5} \mathrm{ATP}$ was reduced by $56 \%$ when assayed at $10^{\circ} \mathrm{C}(\mathrm{P}<0.05)$. Apparent affinity of the hibernator enzyme for ATP was significantly greater at $10^{\circ} \mathrm{C}$ whereas apparent affinity for substrate peptide at $10^{\circ} \mathrm{C}$ was the same for euthermic and hibernating muscle although the hibernator enzyme was more sigmoidal $(\mathrm{P}<0.05)$.

Using the standard assay, the maximal activity of MAPKAP-K2 was determined 
to be $521 \pm 16 \mathrm{nmol} / \mathrm{min} / \mathrm{gram}$ wet weight (gww) in skeletal muscle from euthermic ground squirrels. The value for muscle from hibernating squirrels was significantly lower at $171 \pm 20 \mathrm{nmol} / \mathrm{gww}(\mathrm{P}<0.05)$ or $37 \%$ of the euthermic value (Fig. 6-2). Similarly, the maximal activity of MAPKAP-K2 from euthermic muscle is twice that in muscle from hibernating squirrels when assayed at $10^{\circ} \mathrm{C}$ (Fig. 6-2).

\section{Dephosphorylation}

MAPKAP-K2 is a phosphoprotein. Treatment with alkaline phosphatase was used to evaluate the change in activity when euthermic and hibernating enzymes were dephosphorylated. Dephosphorylation of MAPKAP-K2 decreased the measurable activity to near zero in extracts from both euthermic and hibernating squirrels, the proportional suppression being much greater for the euthermic activity (Fig. 6-2).

\section{Temperature effects on MAPKAP-K2}

The effect of temperature change on MAPKAP-K2 maximal velocity is shown in Figure 6-3 as an Arrhenius plot. The relationship was linear over the range $5-25^{\circ} \mathrm{C}$. The calculated activation energy, $E_{\mathrm{a}}$, for MAPKAP-K2 from muscle of euthermic squirrels was $33.1 \pm 0.2 \mathrm{~kJ} / \mathrm{mol}$. $E_{a}$ for the enzyme from hibernating squirrels was significantly higher, $41.8 \pm 1.9 \mathrm{~kJ} / \mathrm{mol}(\mathrm{P}<0.05)$.

\section{Ion exchange chromatography of MAPKAP-K2}

DEAE-cellulose ion exchange chromatography was used to determine whether multiple forms of MAPKAP-K2 were present in ground squirrel skeletal muscle. Two 
peaks of activity were found in muscle extracts in near equal amounts; in euthermic muscle the ratio was 55:45 for activity in the first and second peaks (eluting at lower and higher salt concentrations, respectively). Total activity in each peak was reduced in hibernator extracts to levels that were $\sim 40-50 \%$ of the euthermic activities.

\section{Western blotting}

Total MAPKAP-K2 protein content of skeletal muscle of euthermic and hibernating ground squirrels was quantified by Western blotting. An antibody specific for the N-terminus of MAPKAP-K2 detected a single band of protein in ground squirrel extracts at the expected molecular mass of $46 \mathrm{kD}$. However, there was no significant difference in MAPKAP-K2 protein content between the two states; compared with a mean normalized euthermic value of 1.0 , the mean hibernator value was $0.93 \pm 0.09$ $(n=4)$ (Fig. 6-2). These data indicate that the differences in activities between euthermic and hibernating states must be due to fine regulation

\section{Structural stability of ground squirrel MAPKAP-K2}

A change in enzyme state between two different physiological conditions could alter the stability of a protein. To assess this, we examined the effects of urea denaturation on ground squirrel MAPKAP-K2. Enzyme activity decreased as [urea] increased with calculated $\mathrm{I}_{50}$ values (inhibitor concentration reducing activity by $50 \%$ ) being $2.20 \pm 0.14 \mathrm{M}$ for euthermic and $2.81 \pm 0.32 \mathrm{M}$ for hibernator muscle, respectively (values are not significantly different). Urea effects on the structural integrity of MAPKAP-K2 were also assessed using the pulse proteolysis method of Park and 
Marquesee (2005). Following exposure to different concentrations of a denaturant (urea), unfolded protein is hydrolyzed by a short pulse treatment with the protease, thermolysin. The remaining amount of folded protein is then detected by Western blotting. Figure 6-4 shows the plot of folded protein remaining as a function of urea concentration. There was no significant difference in the $\mathrm{C}_{\mathrm{m}}$ for urea (concentration of urea that reduced folded protein content by $50 \%)$ between the hibernating $(4.40 \pm 0.88 \mathrm{M})$ and euthermic $(3.71 \pm$ $0.55 \mathrm{M})$ states. 
Table 6-1. $\mathrm{S}_{0.5}$ values for substrates of skeletal muscle MAPKAP-K2 from euthermic versus hibernating Richardson's ground squirrels showing effects of high and low temperature assay. Data are means $\pm \operatorname{SEM}, \mathrm{n}=3$. a - Significantly different from the corresponding euthermic value, $\mathrm{P}<0.05 ; \mathrm{b}$ - significantly different from the corresponding value at $22^{\circ} \mathrm{C}$.

\begin{tabular}{lllll}
\hline & Euthermic & \multicolumn{3}{c}{ Hibernating } \\
& $\mathrm{S}_{0.5}(\mu \mathrm{M})$ & $\mathrm{n}_{\mathrm{H}}$ & $\mathrm{S}_{0.5}(\mu \mathrm{M})$ & $\mathrm{n}_{\mathrm{H}}$ \\
\hline$\underline{\text { ATP }}$ & & & & \\
$22^{\circ} \mathrm{C}$ & $184 \pm 10.2$ & $1.50 \pm 0.12$ & $376 \pm 10.4^{\mathrm{a}}$ & $4.86 \pm 0.92^{\mathrm{a}}$ \\
$10^{\circ} \mathrm{C}$ & $236 \pm 25.4^{\mathrm{b}}$ & $1.24 \pm 0.17$ & $165 \pm 21.0^{\mathrm{a}, \mathrm{b}}$ & $1.57 \pm 0.29^{\mathrm{b}}$
\end{tabular}

MAPKAP-K2 peptide

$\begin{array}{lllll}22^{\circ} \mathrm{C} & 3.12 \pm 0.04 & 3.67 \pm 1.22 & 2.61 \pm 0.01^{\mathrm{a}} & 1.98 \pm 0.08 \\ 10^{\circ} \mathrm{C} & 3.92 \pm 0.33^{\mathrm{b}} & 2.16 \pm 0.01 & 3.62 \pm 0.36^{\mathrm{b}} & 3.26 \pm 1.01^{\mathrm{b}}\end{array}$


Figure 6-1. Activity versus substrate concentration relationships for muscle MAPKAP$\mathrm{K} 2$ from euthermic and hibernating ground squirrels. A: Effect of variation in ATP concentration at both $22^{\circ} \mathrm{C}$ and $10^{\circ} \mathrm{C}$ assay temperatures; B: Effect of variation in MAPKAP-K2 peptide substrate concentration at $22^{\circ} \mathrm{C}$. Data are units $/ \mathrm{mg}$ protein, mean \pm $\mathrm{SEM}, \mathrm{n}=3$ independent determinations on different preparations of enzyme. 


\section{Figure 6-1}
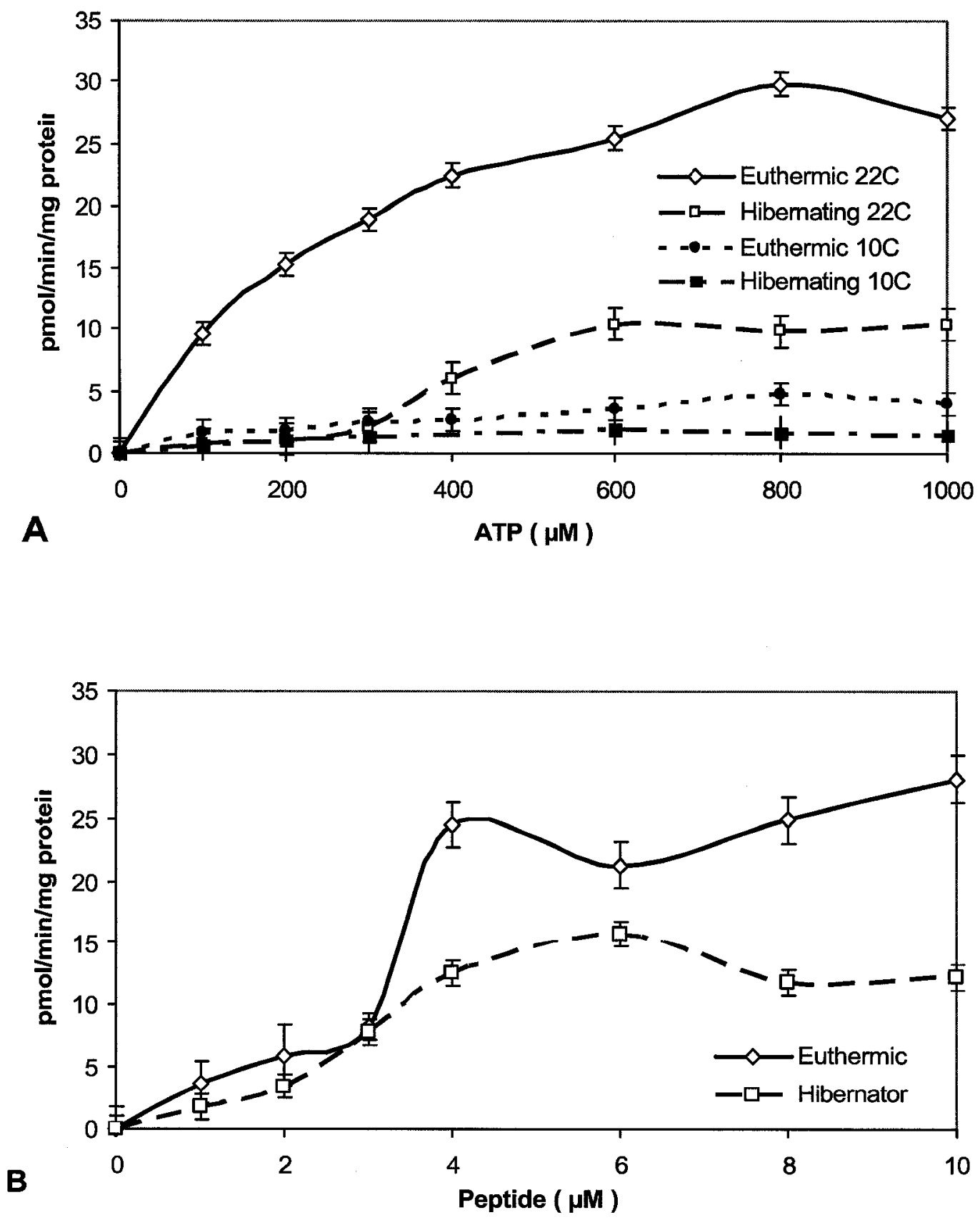
Figure 6-2. Relative MAPKAP-K2 protein content, maximal activity at $22^{\circ} \mathrm{C}$ and $10^{\circ} \mathrm{C}$, and the effect of dephosphorylation by alkaline phosphatase treatment in crude extracts of skeletal muscle from euthermic and hibernating ground squirrels. Enzyme activities are expressed relative to the euthermic values at $22^{\circ} \mathrm{C}$ which are set to 1.0. Protein was assessed by Western blotting. *Significantly different from the corresponding euthermic value, $(\mathrm{P}<0.05)$. 
Figure 6-2.

Total MAPKAP-K2 protein

Euthermic Hibernating
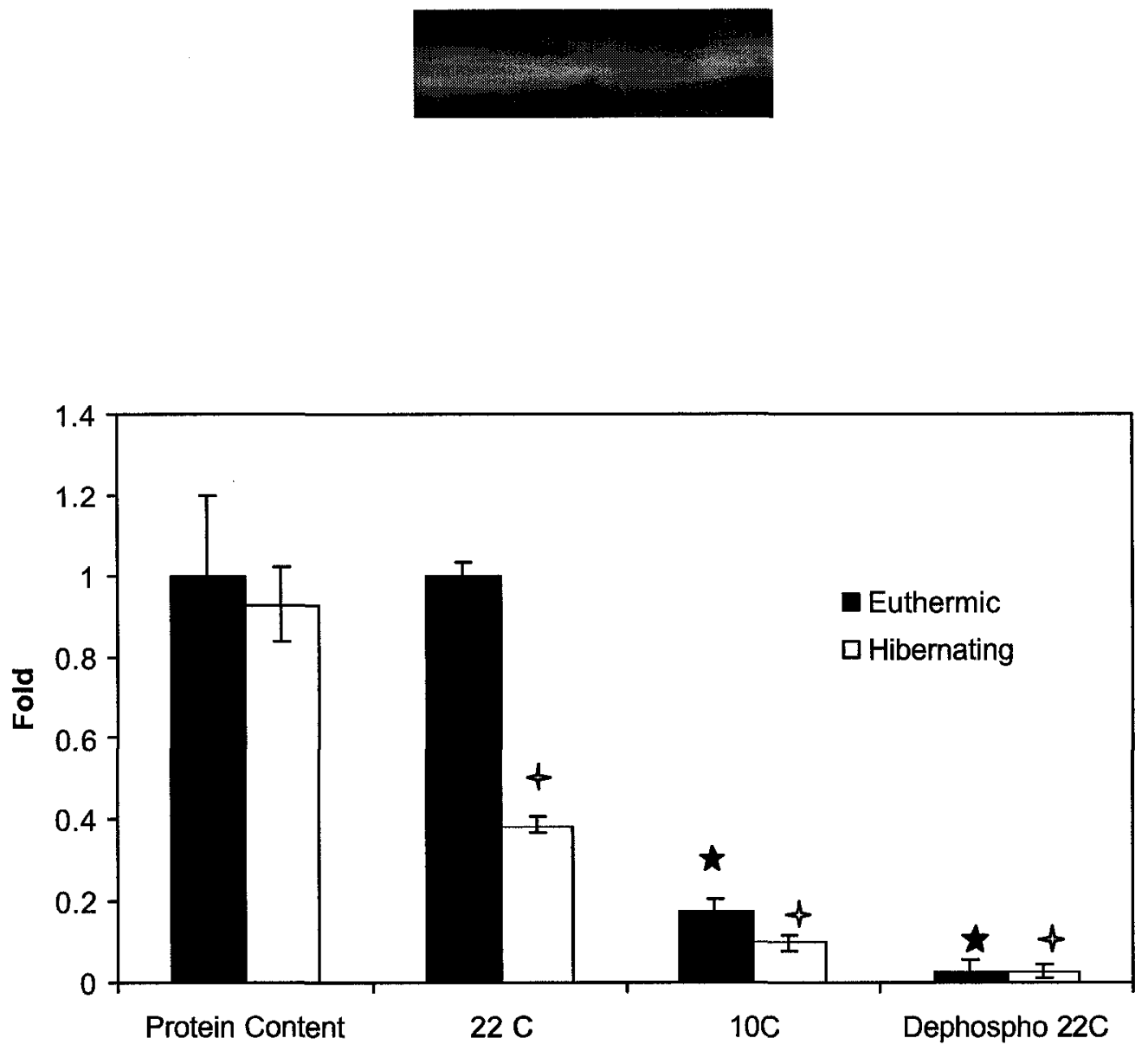
Figure 6-3. Arrhenius plots for MAPKAP-K2 from skeletal muscle of euthermic and hibernating ground squirrels. Data are means $\pm S E M, n=3$ independent determinations on different preparations of enzyme. 
Figure 6-3.

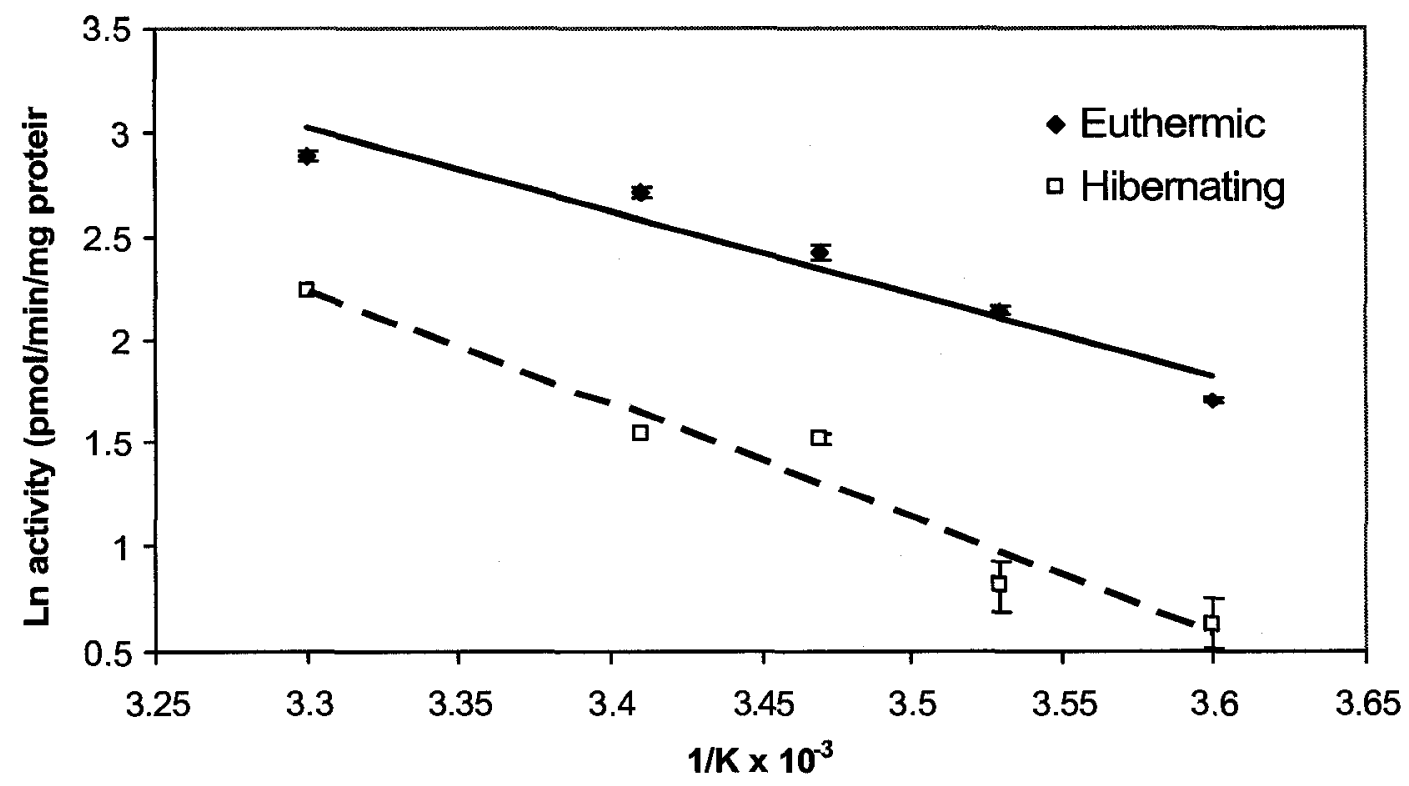


Figure 6-4. Analysis of the chemical stability of muscle MAPKAP-K2 from ground squirrels. Crude extracts from skeletal muscle of euthermic and hibernating ground squirrels were incubated for $24 \mathrm{~h}$ with different concentrations of urea followed by pulse proteolysis to degrade denatured MAPKAP-K2 (1 min incubation with thermolysin) and then Western blotting to measure the amount of native folded MAPKAP-K2 protein remaining. Data are means $\pm \mathrm{SEM}, \mathrm{n}=3$; where error bars are not visible, these are enclosed within the dimensions of the symbol. 
Figure 6-4.

\section{Euthermic}

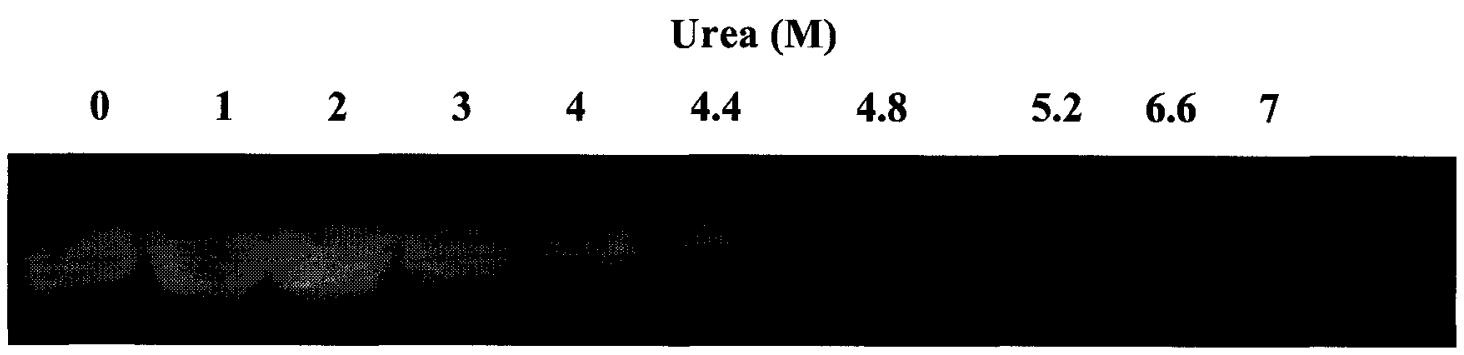

Hibernating
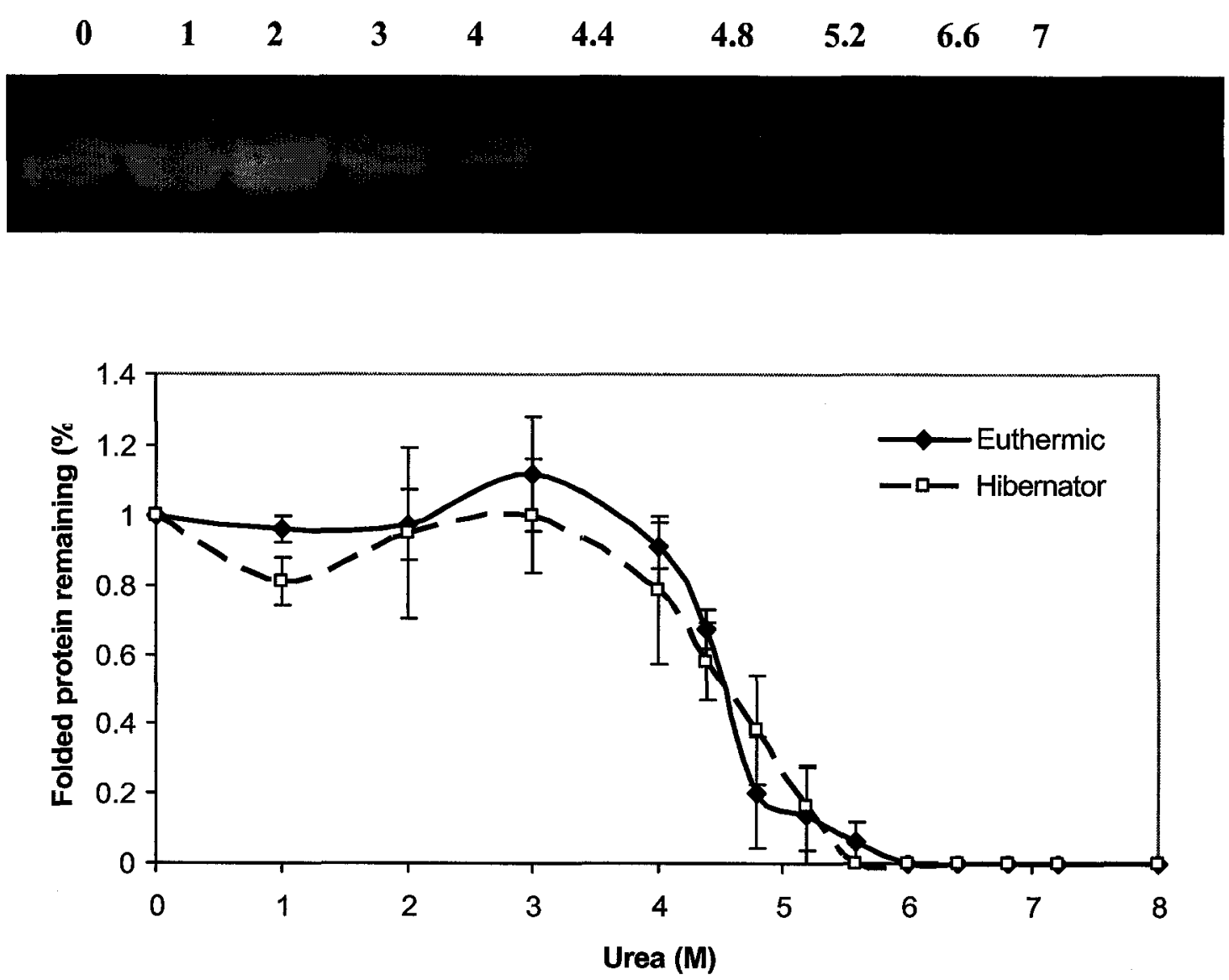


\section{Discussion}

Hibernation is a mammalian strategy for winter survival to cope with poor environmental conditions such low temperatures and lack of food. Hibernators show multiple cellular adaptations that adjust their metabolism for long term viability during cold torpor. The present study examines the properties and regulation of MAPKAP-K2, an important signal transduction enzyme that could be involved in mediating various gene and metabolic changes during hibernation. MAPKAP-K2 is one the direct substrates for $\mathrm{p} 38 \mathrm{MAPK} \alpha$ and $\beta$ and several studies have reported changes in $\mathrm{p} 38$ activity during hibernation, implicating it in directing some of the cellular adaptations involved in hibernation (Zhu et al., 2005; MacDonald and Storey, 2005; Eddy and Storey, 2007). For skeletal muscle, the amount of active phospho-p38 increased during hibernation in both Richardson's ground squirrels and bats, the increase in ground squirrels being nearly 7fold (MacDonald and Storey, 2005; Eddy and Storey, 2007). The reduced activities of muscle MAPKAP-K2 reported here would seem to be at odds with the reported elevation of $\mathrm{p} 38$ during hibernation so this suggests that other influences may contribute to the control MAPKAP-K2 activity during hibernation.

MAPKAP-K2 phosphorylates and regulates a variety of target proteins. Recently, it has been shown that Akt2 is one of these (Hu et al., 2006). Although the best studied mode of $\mathrm{Akt} 2$ phosphorylation and activation is via the PI3K pathway, regulation by MAPKAP-K2 provides an alternative that puts Akt2 under regulation by other influences. The fully active Akt can subsequently phosphorylate physiological substrates that play roles in glucose metabolism, cell proliferation, apoptosis, transcription, and cell migration (Whiteman et al., 2002). Chapter 5 of this thesis reported that total Akt protein 
in skeletal muscle did not change between euthermic and hibernating states but the content of ative, phospho-Akt was reduced by $\sim 40 \%$ during hibernation. Studies on nonmuscle tissues of hibernating little brown bats (Myotis lucifugus) also found 60-70\% reductions in phospho-Akt content during torpor (Eddy and Storey, 2003). This suppression of Akt activity during hibernation is consistent with the present findings about MAPAKAP-K2 and may indicate that hibernation-responsive changes in Akt activity are linked with MAPKAP-K2. A variety of other downstream targets of MAPKAP-K2 are known including glycogen synthase, the small heat shock protein Hsp25/27, tyrosine hydroxylase, 5-lipoxygenase and leukocyte-specific protein 1 (Kotlyarov and Gaestel, 2002; Kotlyarov et al. 2002) as well as regulatory effects on the expression of cytokines such as tumour necrosis factor- $\alpha$ (TNF $\alpha$ ) and interleukin 6 (IL-6) (Neininger et al., 2002; Kotlyarov and Gaestel, 2002). Little is known to date about the role or response of any of these during hibernation and so the role that MAPKAP-K2 might play is hard to predict. HSP27 appears to function in mRNA stabilization and was up-regulated during hibernation in skeletal muscle of bats (Eddy and Storey, 2005) but the situation is unknown for ground squirrels.

The data show that the activity of MAPKAP-K2 was reduced by more than $50 \%$ during hibernation. Western blotting was used to determine if this was due to a reduction in the total amount of MAPKAP-K2 protein present, with the results showing that total MAPKAP-K2 protein content remained the same in euthermic and hibernating animals. This indicates, therefore, that the hibernation responsive decrease in MAPKAP-K2 maximal activity is due to a reduction in the amount of phosphorylated, active enzyme. To confirm this, muscle extracts were incubated with alkaline phosphatase and this 
strongly reduced MAPKAP-K2 activity to near zero in both euthermic and hibernator extracts. Hence, reduced activity of MAPKAP-K2 in muscle from hibernating animals is due to a decrease in the amount of the active phosphorylated enzyme. Two isozymes of MAPKAP-K2 were identified in rat heart (Chevalier and Allen, 2000). To assess the isozyme composition of MAPKAP-K2 in ground squirrel skeletal muscle, DEAE ion exchange chromatography was used. This showed two major peaks of activity, of roughly equal amounts, in euthermic muscle. Activity in both peaks decreased during hibernation to about $40-50 \%$ of the value in euthermic extracts. This is generally consistent with the overall activity decrease in MAPKAP-K2 during hibernation and suggests that the reduced MAPKAP-K2 in hibernation is not due to differential inactivation of one isozyme.

Apart from changes in MAPKAP-K2 activity during hibernation, changes in the kinetic properties of MAPKAP-K2 could also serve to adjust the enzyme for function in active versus torpid states or at high versus low body temperatures. Analysis of MAPKAP-K2 apparent affinity for its substrates showed both state-specific and temperature-specific differences in the enzyme from euthermic versus hibernating animals. $\mathrm{S}_{0.5}$ for both ATP and substrate peptide changed significantly between euthermic and hibernating states and between high and low temperature assay. The sigmoidicity of the velocity versus [substrate] curve also changed in most instances. Notably, however, the $\mathrm{S}_{0.5}$ values for both substrates of euthermic MAPKAP-K2 at warm temperature $\left(22^{\circ} \mathrm{C}\right)$ were almost the same as the corresponding values for the hibernator enzyme measured at cold temperature $\left(10^{\circ} \mathrm{C}\right)$; values were $184 \pm 10 \mu \mathrm{M}$ versus $165 \pm 21 \mu \mathrm{M}$ for $\mathrm{S}_{0.5} \mathrm{ATP}$ and $3.12 \pm 0.04 \mu \mathrm{M}$ versus $3.62 \pm 0.36 \mu \mathrm{M}$ for peptide. Thus, this suggests that 
adjustments to the properties of the hibernator enzyme may be designed to maintain enzyme functional properties at the low body temperatures of the hibernating state. However, MAPKAP-K2 action during torpor may also be influenced by changes in the intracellular concentrations of its ATP substrate which decrease by about $30 \%$ in ground squirrel skeletal muscle during torpor. However, this influence might be small because with $\mathrm{S}_{0.5}$ values for ATP that are $<0.2 \mathrm{mM}$, intracellular ATP concentrations of about 4 $\mathrm{mM}$ in euthermic versus $3 \mathrm{mM}$ in hibernating ground squirrels would likely both be saturating (MacDonald and Storey, 1999).

Temperature change is a critical element in hibernation. Hibernating mammals abandon homeothermy and allow their core body temperature to drop to near $0^{\circ} \mathrm{C}$. Such cold temperatures are lethal for most mammals but hibernators can maintain integrated metabolic and enzymatic functions over a very wide temperature range from $0-37^{\circ} \mathrm{C}$. Interactions between temperature change and enzyme kinetic properties can contribute to the differential regulation of metabolism in the torpid state (Storey, 1997). The maximal activity of MAPKAP-K2 from both euthermic and hibernating animal dropped to $\sim 18 \%$ of the original activity when assayed at $10^{\circ} \mathrm{C}$, compared with $22^{\circ} \mathrm{C}$ (Fig. 6-2). This change is greater than the normally expected $\mathrm{Q}_{10}$ value for enzymatic reactions; typically $\mathrm{Q}_{10}$ is about 2 which is equivalent to a $50 \%$ decrease in activity when temperature is reduced by $10^{\circ} \mathrm{C}$. Furthermore, the Arrhenius plot showed that the activation energy of the enzyme increased significantly during hibernation (Fig. 6-3) which could argue for a modification of the enzyme during hibernation; such a modification was also suggested from the differences in $\mathrm{S}_{0.5}$ values between euthermic and hibernating states. However, ground squirrel MAPKAP-K2 showed a linear response to temperature change over the 
full range of temperatures tested $\left(5-25^{\circ} \mathrm{C}\right)$ with no indication of a "break" in the line such as would indicate a temperature-dependent conformational change. This suggests that temperature change is not an impediment to enzyme function as body temperatures fall and rise over cycles of euthermia and torpor.

The chemical stability of ground squirrel skeletal muscle MAPKAP-K2 was also analyzed. The $\mathrm{I}_{50}$ values $(2.2-2.8 \mathrm{M})$ for loss of enzymatic activity in the presence of urea did not differ between euthermic and hibernating states nor did the $C_{m}$ values (3.7-4.4 M) that measured structural denaturation by urea. However, it can be noted that urea inhibited enzyme activity at substantially lower concentrations than those that were required for structural denaturation of MAPKAP-K2. Furthermore, given that the data for activity and for alkaline phosphatase effects on the enzyme indicate a very different content of active phosphoenzyme between euthermic and hibernating states, it can be inferred that phosphorylation state of MAPKAP-K2 does not have a significant effect on the structural stability of the enzyme. 


\section{Chapter 7}

\section{GENERAL}

\section{DISCUSSION}


Hibernation is the key to winter survival for a variety of mammals. For ground squirrels, the cold ambient temperatures and lack of food (grasses, seeds, etc) to graze on causes animals to retreat into their underground burrows and hibernate for many months. Hibernation is characterized by long periods of deep torpor that are interrupted by short periods of arousal. Metabolic rate is often reduced to just $1-5 \%$ of the corresponding basal rate in euthermia (Geiser, 2004) and core body temperature falls to near ambient, often as low as $0-5^{\circ} \mathrm{C}$. All physiological processes including heart rate, blood flow and kidney filtration are reduced to low levels. Animals spend days or weeks in torpor and then arouse back to $\sim 37^{\circ} \mathrm{C}$ and restore physiological parameters for short periods of time before sinking back into another cycle of torpor. Heat production for arousal comes initially and primarily from thermogenesis in brown adipose tissue but is supplemented by skeletal muscle shivering once the body is partly rewarmed. Precise metabolic regulation is needed to coordinate metabolic suppression, reorganize fuel metabolism, and sustain a viable energetic state. Torpor has a direct effect on the adenylate energy currency of cells. Several studies have reported a decrease in the total adenylate pool during hibernation by 33\% in Cynomys leucurus (English and Storey, 2001), $40-50 \%$ in Zapus hudsonius (Kelly and Storey, 1995), and 30\% in Spermophilus lateralis (MacDonald and Storey, 1999). Adenylate energy charge is more important than the total adenylate pool for the viability of the cells and, in spite of the changes in the total adenylate pool, hibernators maintain a stable and high energy charge [ATP + 0.5ADP] / [ATP + ADP + AMP] of around 0.90 during torpor (English and Storey, 2000; MacDonald and Storey, 1999).

A number of previous studies have shown that the metabolic adjustments required 
for hibernation depend to a large extend on the regulation of existing enzymes and proteins, coupled with selected changes in gene expression, but with no major changes in metabolism or enzyme/protein types as compared with normal mammals. Because of this, I undertook a series of studies of enzymes in this thesis, analyzing the properties of these from euthermic and hibernating states. Each enzyme was chosen because of its potentially key role in hibernation. Hexokinase is the first enzyme in the metabolism of glucose and regulation of this enzyme has direct effects on both the storage and consumption of glucose, as well as on the pathways such as glycolysis and the pentose phosphate pathway that use glucose. Creatine kinase has a central role in cellular energetics, buffering ATP and mediating the $\mathrm{PCr} / \mathrm{Cr}$ shuttle to move ATP equivalents around the cell from sites of ATP synthesis (mitochondria) to sites of consumption AMPD deaminase is another enzyme that is involved in cellular energetics and helps to control the relative concentrations of adenylates by (a) the irreversible deamination of AMP to remove it from the adenylate pool, and (b) helping to drive the adenylate kinase by removing its AMP product (Figure 7-1). Akt and MAPKAP-K2 are two important enzymes in signal transduction. Akt has a major role in transducing insulin signaling and is involved in regulating glycogen synthesis, glucose transport, lipid and glycogen synthesis, among others. MAPKAP-K2 is a key component of the p38 MAPK signaling cascade, the p38 pathway being a major route by which environmental stress messages are transmitted to the nucleus to stimulate stress-specific gene expression(Figure 7-2). Each of these enzymes plays appears to have its own role to play in hibernation 
Figure 7-1. Relation between CK and AMPD. CK is a fast ATP-regenerating enzyme and a low-threshold sensor for ADP. Two products of cellular ATPases, ADP and $\mathrm{H}^{+}$, are substrates of the $\mathrm{CK}$ reaction and are consumed during the CK catalyzed regeneration of ATP. Thus, CK action prevents local acidification near cellular ATPases as well as a build-up of ADP. The latter would otherwise lead, after a series of enzymatic conversions, to a net loss of cellular adenine nucleotides, which would be deleterious for a cell. The adenylate kinase reaction converts two ADP molecules to one molecule each of ATP and AMP (Wallimann et al., 1992). 


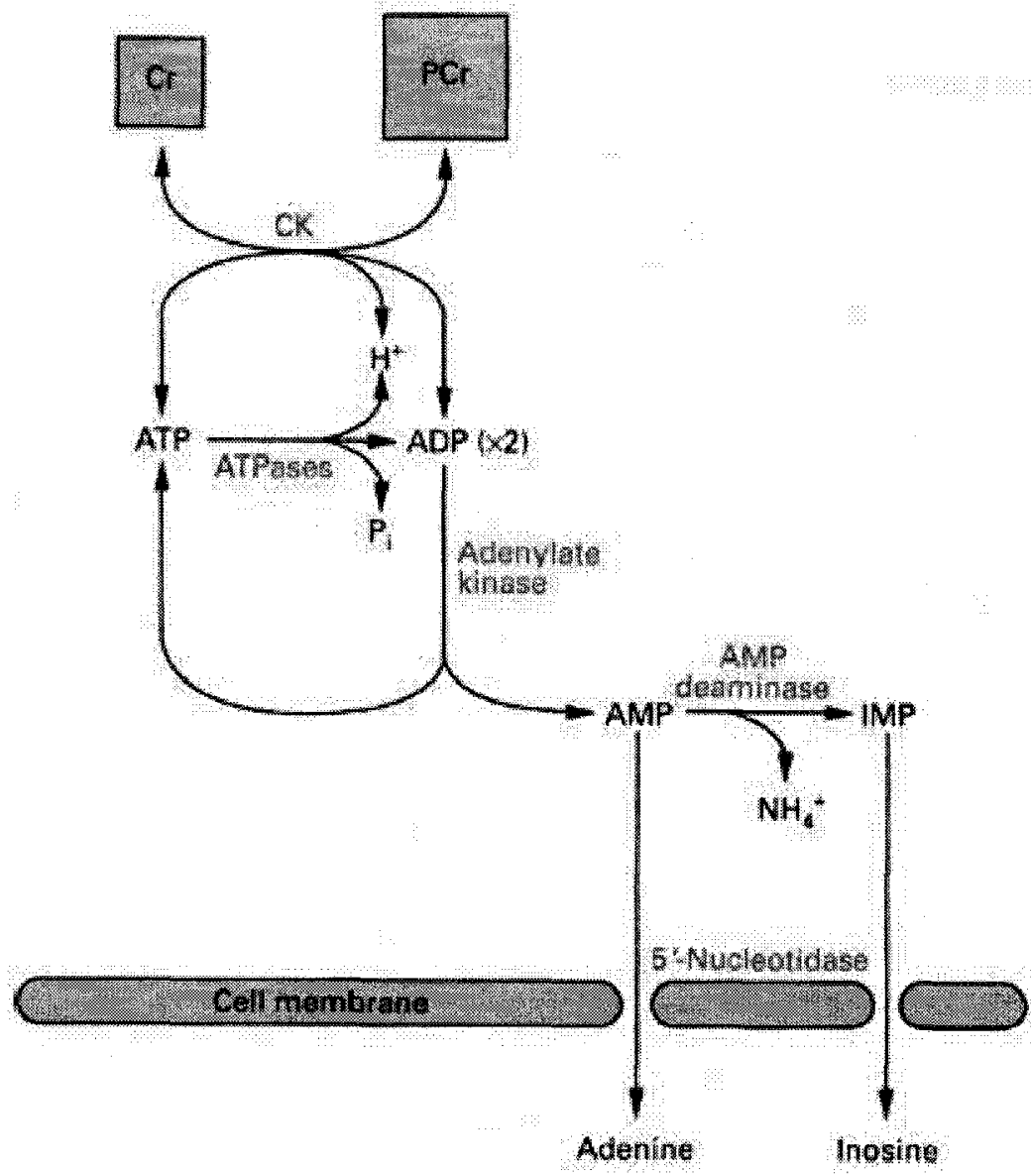


Figure 7-2. MAPK signalling pathways (Cowan and Storey, 2003) 


\begin{tabular}{|c|c|c|}
\hline Mitogens: & Stress Cytckines & Stresulyolutues \\
\hline ERK $1 / 2$ pathwoy & NNK pathway & pos patturay \\
\hline
\end{tabular}

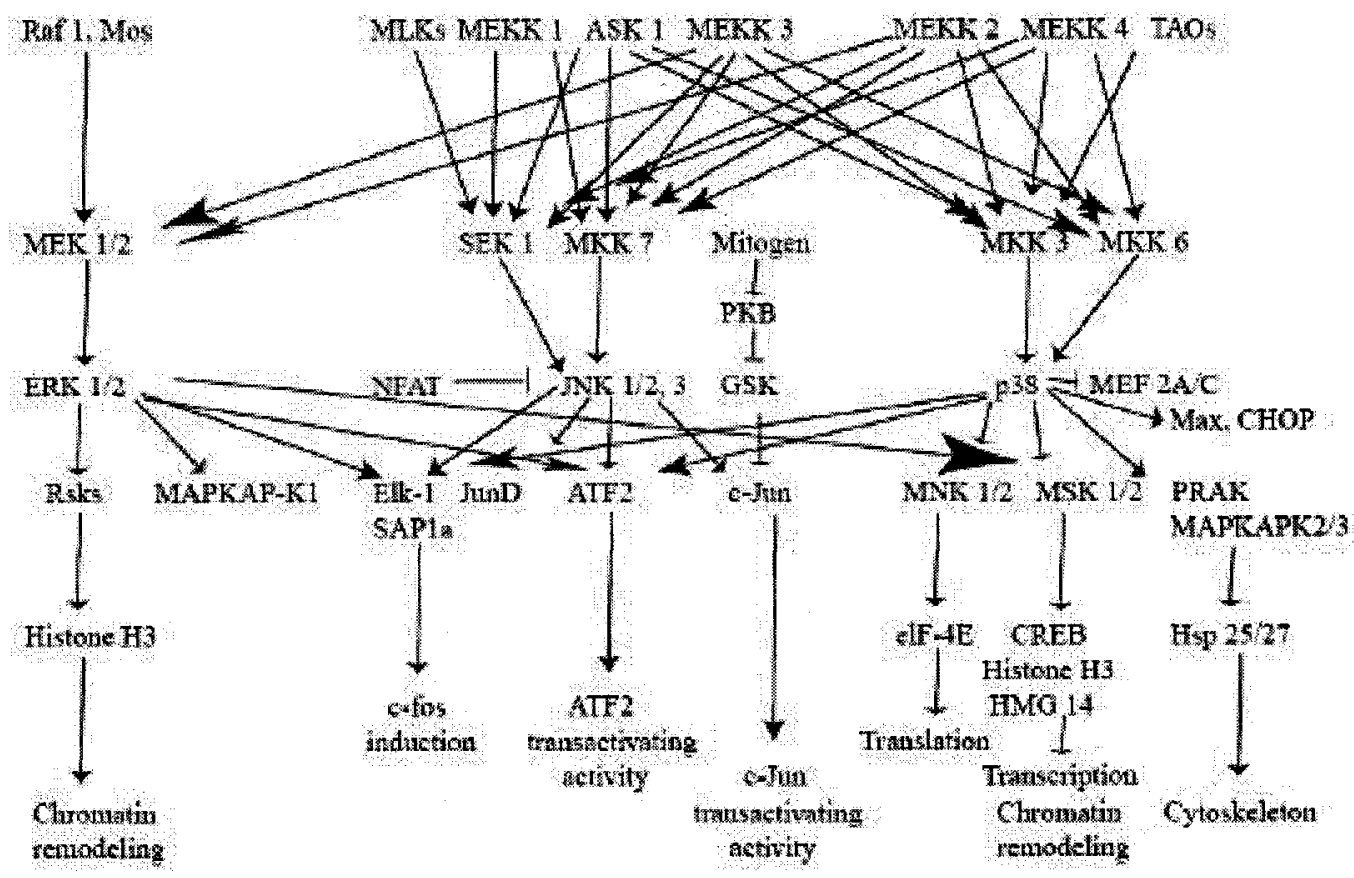


My study of hexokinase (mainly HKII) from ground squirrel skeletal muscle showed that the activity of the enzyme during hibernation was $\sim 33 \%$ lower than in euthermia when assayed at $22^{\circ} \mathrm{C}$. Reduced maximum activity of this enzyme may reflect reduced consumption of glucose by muscle during hibernation as it is known that the primary fuel for most tissues during torpor is lipid. Moreover, the data showed that low temperature, $5^{\circ} \mathrm{C}$, had a high impact on $\mathrm{HK}$ activity; activity was reduced by $82 \%$ and $84 \%$ when assayed at $5^{\circ} \mathrm{C}$, compared with $22^{\circ} \mathrm{C}$, in muscle extracts from both euthermic and hibernating animals, respectively. The kinetic experiments showed that the $\mathrm{K}_{\mathrm{m}}$ ATP was $\sim 80 \%$ higher for the hibernator enzyme, compared with euthermic $\mathrm{HK}$, at $22^{\circ} \mathrm{C}$. However, lowering temperature to $5^{\circ} \mathrm{C}$ reversed this effect suggesting that $\mathrm{HK}$ from hibernating animals was altered for optimal function in the cold. However, temperature change did not affect the apparent affinity of euthermic HK for ATP or the $\mathrm{K}_{\mathrm{m}}$ glucose from either euthermic or hibernating animals. These experiments indicated that ATP is more important than glucose in the regulation of HK during hibernation. Studies of HK from a cold hardy insect, Epiblema scudderiana, similarly found temperature-dependent kinetics (Muise and Storey, 2001); HK had a higher apparent affinity for both glucose and ATP $\left(\mathrm{K}_{\mathrm{m}}\right.$ values were $45-50 \%$ lower) at low temperature $\left(5^{\circ} \mathrm{C}\right)$. The insect study also reported a sharp break in the Arrhenius relationship at $12-16^{\circ} \mathrm{C}$ and concluded that temperature change caused a conformational change in the HK protein. However, ground squirrel HK did not show a break in the Arrhenius line or a significant difference in Ea between HK from euthermic and hibernating animals.

Creatine kinase also showed a significant reduction in maximal activityduring hibernation and in enzyme apparent affinity for both creatine and ATP substrates. The 
reduced CK activity during hibernation may reflect the much lower rates of ATP turnover needed during torpor due to the quiescent state of muscle. Studies of the effect of temperature on $S_{0.5}$ for creatine showed that $S_{0.5}$ decreased (apparent affinity increased) with decreasing temperature; the minimum value was at low temperature $\left(2-5^{\circ} \mathrm{C}\right)$ and $\mathrm{S}_{0.5}$ rose $\sim 3$-fold as temperature increased to near-euthermic values $\left(30^{\circ} \mathrm{C}\right) . \mathrm{S}_{0.5}$ ATP also showed its minimum $\mathrm{S}_{0.5}$ at $2^{\circ} \mathrm{C}$ with increasing values as temperature increased to 20 $25^{\circ} \mathrm{C}$. However, at higher temperatures $\left(30^{\circ} \mathrm{C}\right), \mathrm{S}_{0.5}$ values decreased again. Arrhenius plots showed that the Ea value for hibernator CK was significantly higher, by18\%, than the euthermic value which also indicate suppression of $\mathrm{CK}$ at lower temperatures.

The maximal activity of AMPD decreased during hibernation in both Richardson's and 13-lined ground squirrels, by 70 and $84 \%$ respectively. Apparent affinity of the enzyme for its substrate was also lower during hibernation in both species; $K_{m}$ was about $35 \%$ higher during hibernation. Kinetic study of AMPD from hibernating ground squirrels did not show a significant difference in apparent affinity for AMP over a range of temperatures from 10 to $35^{\circ} \mathrm{C}$. At the same time the maximum activity of the enzyme at $5^{\circ} \mathrm{C}$ was reduced by $\sim 4$ fold as compared to the activity at $22^{\circ} \mathrm{C}$. This reduction in both AMPD activity and its apparent affinity for AMP during hibernation could suppress the catabolism of AMP. During muscle exercise the action of AMPD removes AMP from the total adenylate pool and this helps to stabilize the adenylate energy charge and to draw the adenylate kinase reaction toward ATP synthesis. The reaction also removes protons that accumulate as a result of anaerobic glycolysis through the formation of $\mathrm{NH}_{4}{ }^{+}$(Mommsen and Hochachka, 1988). The reduction in AMPD activity during hibernation is probably a response to the reduced rates of ATP turnover 
and the general lack of muscular activity in torpor. Change in kinetic parameters of AMPD may also alter it for optimal function during torpor. Thus, AMPD from hibernator muscle was less sensitive to ATP activation and to $\mathrm{NH}_{4}{ }^{+}$and $\mathrm{PO}_{4}{ }^{3-}$ inhibition than was the euthermic enzyme whereas $\mathrm{Mg}^{2+}$ was a stronger inhibitor of the hibernator enzyme.

Akt activity was also reduced during hibernation, by $60 \%$ in skeletal muscle and $66 \%$ in liver when activities were measured at $22^{\circ} \mathrm{C}$. Muscle Akt from hibernators also showed a very large increase (3.3-fold) in $\mathrm{S}_{0.5}$ ATP as compared with the enzyme from euthermic muscle but the $\mathrm{S}_{0.5}$ ATP for euthermic Akt also rose by a similar amount (3.5fold) when Akt was assayed at low temperature $\left(10^{\circ} \mathrm{C}\right)$. Thus, both low temperature and hibernation reduce the capacity for Akt function by affecting ATP kinetics. Furthermore, Akt action could be further compromised in the hibernator by the decrease in ATP levels in ground squirrel muscle during torpor. The last enzyme in this study was MAPKAP-K2 which was also regulated during hibernation. The data show $\sim 50 \%$ reduction in MAPKAP-K2 activity during hibernation coupled with a $100 \%$ increase in $\mathrm{S}_{0.5}$ for ATP. Moreover, the velocity versus $[\mathrm{ATP}]$ curves showed a very strong sigmoidal property during hibernation ( $\mathrm{n}_{\mathrm{H}}=1.5$ in euthermic animals rising to 4.86 in hibernating). Furthermore, the activities of MAPKAP-K2 from both euthermic and hibernating animals dropped to $\sim 18 \%$ at $10^{\circ} \mathrm{C}$ compared with activities at $22^{\circ} \mathrm{C}$. Interestingly, apparent affinity of MAPKAP-K2 for both peptide and ATP in euthermic animals at warm temperature $\left(22^{\circ} \mathrm{C}\right)$ were almost the same as the corresponding values for the hibernator enzyme measured at cold temperature $\left(10^{\circ} \mathrm{C}\right)$. This suggests that adjustments to the properties of the hibernator enzyme may be designed to maintain enzyme functional properties at the low body temperatures of the hibernating state. 
My results showed that all of these enzymes showed reduced $V_{\max }$ and different kinetics parameters during hibernation. Furthermore, low temperature had differential impacts on the kinetic parameters of the five enzymes. For example, except for HK and Akt, the activation energy, Ea, was significantly higher for enzymes from hibernating animals.

Binding to myofibrils is another regulatory mechanism that can impact enzyme function The three metabolic enzymes assessed in this thesis (HK, CK, AMPD) are all known to bind to subcellular structures and show changes in the percent bound under different physiological conditions. However, the present studies found no significant difference in the percentage of bound CK, HK and AMPD between euthermia and hibernation. Furthermore, binding only affected the apparent affinity of HK for glucose from euthermic animals. Pastorino et al. (2005) reported that the binding of HKII to mitochondria helped to protect cells against a loss of cell viability due to apoptosis. $\mathrm{S}_{0.5}$ creatine of bound CK from euthermic animals was $25 \%$ lower as compared with soluble CK but $\mathrm{S}_{0.5}$ ATP was unaffected.

Coarse controls involving changes in transcription and translation also play important roles in the regulation of enzymes and the present studies assessed total protein levels for most of the enzymes as well as mRNA transcript levels of CK. The data found no changes in the total protein content of Akt and MAPKAP-K2 between euthermic and hibernating animals whereas $\mathrm{HK}$ and $\mathrm{CK}$ showed a $20 \%$ reduction in their protein level in torpid animals. This may be due to an altered balance between protein synthesis and protein degradation in torpor. Both transcriptional and translational suppression are well known components of hibernation (Storey and Storey 2004). Hibernator muscle also 
showed a very strong reduction in CK mRNA levels which indicated that the reduced protein content may result primarily from reduced transcription of the CK gene. Unlike the metabolic enzymes that have constitutive activity in cells, many signal transduction enzymes are regulated in an on-off manner by reversible phosphorylation. Hence, the total amount of protein can be preserved during torpor because the activity/function of these enzymes is strictly determined by their phosphorylation state. Notably, then, phospho-Akt content in muscle was $\sim 40 \%$ lower during hibernation compared with euthermia and, in liver, phospho-Akt was 10 times less than that in euthermic animals. The content of active phosphorylated MAPKAP-K2 was also much lower in hibernation.

Posttranslational control of enzymes by reversible phosphorylation is also extremely important to the regulation of many metabolic enzymes. Indeed, protein phosphorylation regulates almost all aspects of cell life. Some metabolic enzymes are controlled in an on-off manner similar to that seen with signal transduction enzymes, glycogen phosphorylase being a prime example. However, more often the effects of phosphorylation on metabolic enzymes are to modulate the properties of the enzyme including activity, substrate apparent affinity, sensitivity to inhibitors and activators, and enzyme binding to subcellular components. Simplicity, flexibility, and reversibility underlie the use of phosphorylation to regulate many biological processes, including metabolic rate control. Protein kinases are responsible for the addition of phosphate groups to proteins, whereas protein phosphatases break the covalent bond between protein and phosphate group. The addition of a phosphate group or groups has several effects on protein structure including: (a) an increase in the overall negative charge on the protein, (b) a reduction in the isoelectric point of the protein,(c) an increase in 
hydrophilicity of the protein, and (d) repulsion between the negative charge on phosphate and other negatively charged groups that may cause conformational changes in the protein. Protein phosphorylation in animal cells typically targets serine or threonine residues (both have a free hydroxyl group) or tyrosine residues (which feature a phenolic group). Covalent modification of the proteins by phosphorylation is known to be involved in (a) activation of receptors, (b) signal transduction (c) gene expression by activation of transcription factors, (iv) regulation of protein synthesis by phosphorylation of ribosomal factors, and (v) post-translational modifications of proteins, to name a few (Storey, 2003). In this thesis we showed that reversible protein phosphorylation plays a crucial role in the regulation of metabolism during hibernation

My studies showed that the phosphorylation state of ground squirrel skeletal muscle HK changes during hibernation. Of the protein kinases tested, stimulation of AMPK was the only one that significantly increased HK activity in extracts of hibernator whereas several protein phosphatases, most prominently PP1, reduced HK activity in both euthermic and hibernating muscle. AMPK treatment of hibernator HK also reduced its $K_{m}$ for ATP by about $40 \%$ to the values seen for euthermic HK. AMPK treatment also shifted the elution pattern of HK off DEAE Sephadex which implies an altered phosphate content of the enzyme. PP1 treatment of euthermic HK had the opposite effect on the elution pattern although PP1 treatment did not change $K_{m}$ values for ATP and glucose. The pattern of response by hibernator HK activity to protein kinases and phosphatases, as well as the dual peak elution pattern, suggests that soluble HK in hibernating muscle is partially phosphorylated whereas the responses by soluble euthermic HK were consistent with an enzyme that is fully phosphorylated. 
Reversible phosphorylation also contributes to the regulation of muscle $\mathrm{CK}$ during hibernation. Stimulation of PKA, PKC, PKG significantly reduced soluble CK activity in extracts of euthermic muscle as well as bound CK from hibernator muscle. All three protein kinases, as well as AMPK, also stimulated ${ }^{32} \mathrm{P}$ labelling of CK. Effects of PKA treatment of euthermic CK were further analyzed and in addition to its affect on $\mathrm{V}_{\max }$, PKA treatment also reduced CK apparent affinity for ATP, mimicking the effects of hibernation on $\mathrm{S}_{0.5}$ ATP and its Hill coefficient. Ground squirrel CK was also responsive to dephosphorylation by protein phosphatases; incubations that promoted the actions of total protein phosphatases, serine/threonine protein phosphatases, PP1, and PP2B all led to significant increases in the activity of soluble CK in extracts from both euthermic and hibernating muscle. Stimulation of total protein phosphatases also decreased $\mathrm{S}_{0.5}$ ATP and $\mathrm{n}_{\mathrm{H}}$ of hibernator CK to values very close to those of euthermic CK. This pattern suggests that soluble CK in hibernating muscle is fully phosphorylated whereas euthermic CK was a mix of high and low phosphate forms. The elution patterns of euthermic and hibernator CK from DEAE Sephadex supported this.

AMPD also showed strong regulation by reversible phosphorylation. Stimulation of protein phosphatase activities decreased AMPD activity in euthermic extracts by 50$90 \%$ but did not affect the enzyme in hibernating animals. Stimulation of protein kinases A, C and G all increased AMPD activity several fold in both euthermic and hibernating extracts. Analysis of $\mathrm{K}_{\mathrm{m}}$ AMP after incubation with different protein kinases showed that almost all of the tested protein kinases reduced the $\mathrm{K}_{\mathrm{m}}$. Elution from the DEAE column showed that the enzyme was highly phosphorylated in the euthermic state, while the low phosphate form predominated in hibernating muscle and an intermediate peak was 
present in both euthermic and hibernating animals.

My studies also assessed the stability the enzymes from euthermic and hibernating animals. Enzyme sensitivity to urea denaturation was analyzed using the technique of pulse proteolysis with thermolysin to digest urea-denatured enzyme followed by Western blotting to visualize the amount of native protein remaining. This technique was applied to $\mathrm{HK}, \mathrm{CK}$ and MAPKAP-K2 and showed that muscle HKII from hibernating animals was significantly more stable than the enzyme from euthermic animal. This raised this idea that phosphorylation decreases the stability of HK. However, stability of MAPKAP-K2 and CK to urea denaturation did not change between the two physiological states.

\section{Conclusion}

In conclusion, in this thesis, I demonstrated that five metabolic and signal transduction enzymes show altered properties during hibernation in skeletal muscle of ground squirrels, generally consistent with reduced activity and metabolic function in the torpid state. Changes in total protein content or mRNA transcript levels or changes in enzyme binding to subcellular components were partially responsible for the hibernation responsive changes in enzyme activity in some cases. However, reversible protein phosphorylation proved to be extremely important in metabolic control during hibernation including effects on enzyme activity, kinetic properties, and stability against chemical denaturation Moreover, roles for several specific protein kinases and protein phosphatases were indicated in the control of selected enzymes during hibernation 


\section{New directions}

The studies described in this thesis identified many interesting aspects of enzymatic regulation during hibernation but also suggest several new directions for future work. Three directions that I believe are key are outlined below.

\section{Effect of fatty acids on the metabolic enzyme activity}

It is known that some metabolic enzymes, like hexokinase, are inhibited by free fatty acids (Stewart and Blakely, 2000). We also know that fatty acids and ketones are the major fuel sources for cells during hibernation. Hence, the effects of fatty acids may be of importance to the control of enzymes in hibernation and a study of the effects of lipids on the kinetic parameters of HK, CK, AMPD, Akt and MAPKAP-K2 would be useful. Moreover, the length of fatty acids and degree of saturation could also influence enzyme properties and could be studied. In cases where significant changes in kinetic parameters occur, a study of the binding parameters of the enzyme and fatty acids could be undertaken using isothermal calorimetry (ITC). My thesis studies showed that reversible protein phosphorylation plays a very important role in the regulation of enzymes during hibernation. Hence, another study that could be undertaken would be to look for interactions between protein phosphorylation state and the binding of enzymes to fatty acids with different saturation degree and length. Moreover, the stability of these enzymes in the presence and absence of the fatty acids could be studied. Methods such as measurement of the activity over time, pulse proteolysis, intrinsic tryptophan fluorescence and ANS could be used to analyze the stability of enzymes in the presence versus absence of fatty acids. 


\section{Signal transduction}

As noted earlier, hibernation does not involve a major reorganization of cellular metabolism but seems to be controlled more by reversible mechanisms that allow coordinated entry into and arousal from torpor. Reversible protein phosphorylation appears to be a major mechanism and hence protein kinases appear to be central to regulatory control. My thesis addressed two of these, Akt and MAPKAP-K2, but I have identified three others that could have potentially important actions in metabolic control in hibernators and that should be investigated. Studies could include analysis of transcriptional and translational controls, Western blotting to determine levels of active versus total enzyme, kinetic analysis, temperature effects, and assessment of conformational stability by pulse proteolysis and other methods. Also, extended studies of the responses to hibernation by known downstream targets of these protein kinases can be undertaken to understand the breadth of effects of these protein kinases in mediating entry into and arousal from torpor.

AMPK: The AMP-activated protein kinase (AMPK) system acts as a sensor of cellular energy status. This enzyme is activated by increases in the cellular AMP:ATP ratio caused by metabolic stresses that either interfere with ATP production (e.g. deprivation for glucose or oxygen) or that accelerate ATP consumption (e.g. muscle contraction). Upon activation, AMPK stimulates ATP-generating catabolic pathways and suppresses ATP-consuming processes (Hardie and Pan, 2002). It is already shown that acetyl-CoA carboxylase (ACC), a rate-limiting enzyme in fatty acid synthesis, is controlled by AMPK (Davies et al., 1990). AMPK could be another important signal 
transduction enzyme operating during hibernation. In my stud ies, I showed that AMPK increased the activity of $\mathrm{HK}$ in muscle extracts of hibernating ground squirrels. I also showed that stimulation of AMPK in muscle extracts increased ${ }^{32} \mathrm{P}$-labeling of $\mathrm{CK}$ although CK activity did not change. AMPD was also responsive to phosphorylation by AMPK with a significant decrease in $\mathrm{K}_{\mathrm{m}}$ AMP. Based on these observations, it is likely that AMPK has a significant role in regulating enzymes during hibernation. An initial study has shown differential effects of hibernation on AMPK activity and phosphorylation state in organs of ground squirrels (Rider et al., 2005). In particular, major changes in AMPK were identified in liver and white adipose tissue during hibernation. These justify a full kinetic study of the enzyme.

GSK: Glycogen synthase kinase 3 (GSK3) is important for normal development, regulation of metabolism, neuronal growth and differentiation and modulation of cell death (Kockeritz et al., 2006). Activity of this enzyme is inhibited by phosphorylation. The enzyme was first identified as a key regulator of glycogen synthase activity (and therefore has a key role in carbohydrate storage in cells) but is now known to have a range of targets in metabolism. GSK3 is a direct substrate of Akt and in Chapter 5 I showed that the activity and substrate apparent affinity of Akt decreased during the hibernation. This would clearly affect GSK3 and hence GSK3 would be a good candidate for regulation during hibernation.

PKG: The cyclic 3'5'-guanosine monophosphate (cGMP) dependent protein kinase (PKG). In mammals, PKG is known to respond to changes in nitric oxide as one trigger but its full actions are far from known. For example, PKG has been found to activate lipolysis in adipocytes by stimulation of arterial natriuretic peptide (ANP) 
(Carmen and Víctor, 2005)). PKG is known to play a important role in invertebrate metabolic rate depression including the control of several enzymes of carbohydrate metabolism during estivation in land snails and anoxia exposure in marine snails (Brooks and Storey, 1997). A general role for PKG in metabolic rate depression may occur. My experiments showed that stimulation of $\mathrm{PKG}$ increased the activity of $\mathrm{CK}$ from skeletal muscle of euthermic ground squirrels and also increased both the activity and apparent affinity of AMPD. These findings suggest that PKG is an important signal transduction enzyme in hibernation. Hence, future studies should include analysis of the kinetic parameters of PKG during hibernation.

\section{Glucose-6-phosphate dehydrogenase}

Glucose-6-phosphate dehydrogenase (G6PDH), the first and rate-limiting enzyme of the pentose phosphate pathway (PPP), is indispensable to maintenance of the cytosolic pool of NADPH. The PPP has several roles in metabolism including production of 3-7 carbon sugar phosphates (most notably ribose-5-P for nucleotide biosynthesis), and creating NADPH reducing power for biosynthesis and cellular redox balance (e.g. production of reduced glutathione and reduced thioredoxin). Biosynthesis is reduced during hibernation but antioxidant defenses are critical both for long term viability during torpor and to deal with high levels of oxidative stress associated with thermogenesis during arousal. Hence, regulation of G6PDH could be important in hibernation. In addition, Ramnanan and Storey (2006) showed that this enzyme was regulated by reversible phosphorylation during estivation in land snails, Otala lactea, which suggests that it may also be regulated in a mammalian form of dormancy. Moreover, in Chapter 2 
I showed that the activity of HKII, that produces glucose-6-P, decreases during hibernation. So, the question is how does G6PDH respond to hibernation? Studies of hibernator G6PDH should include analysis of kinetic properties, regulatory mechanisms such as $\mathrm{pH}$, activators and inhibitors, susceptibility to reversible phosphorylation, temperature effects on activity substrate affinities, and stability studies. 


\section{LIST OF PUBLICATIONS}


Abnous K and Storey KB (2007) Regulation of skeletal muscle creatine kinase from a hibernating mammal, Arch. Biochem. Biophys. (Accepted)

Abnous K and Storey KB, Skeletal muscle hexokinase: regulation in a hibernating ground squirrel (Submitted to Int. J. Biochem. Cell Biol.)

Abnous K, Dieni CA and Storey KB, Regulation of Akt during hibernation in Richardson's ground squirrels (Submitted to Biochim. Biophys. Acta)

Abnous K, Dieni CA and Storey KB, Regulation of MAPKAP-K2 in Richardson's ground squirrels, Spermophilus richardsonii, during hibernation (In preparation)

Abnous K and Storey KB, AMP deaminase regulation in Richardson's and 13-lined ground squirrek during hibernation (In preparation) 


\section{REFERENCES}


Abnous K and Storey KB (2007) Regulation of skeletal muscle creatine kinase from a hibernating mammal, Arch. Biochem. Biophys. in press.

Alessi DR, James SR, Downes CP, Holmes AB, Gaffney PR, Reese CB, Cohen P (1997) Characterization of a 3-phosphoinositide-dependent protein kinase which phosphorylates and activates protein kinase Ba, Curr. Biol. 7: 261-269.

Andrews MT (2004) Genes controlling the metabolic switch in hibernating mammals, Biochem. Soc. Trans. 32: 1021-1024.

Ashby B, Frieden C (1997) Interaction of AMP and aminohydrolase with myosin and its subfragments, J. Biol. Chem. 252: 1869-1872.

Ashby B, Frieden C (1978) Adenylate deaminase kinetics and binding studies on the rabbit muscle enzyme, J. Biol. Chem. 253: 8728-8735.

Bai JH, Zheng SY, Zhou HM (1998) Inactivation of creatine kinase is due to the conformational changes of the active sites during thermal denaturation, Biochem. Mol. Biol. Int. 45: 941-951.

Bakheet T, Frevel M, Williams BR, Greer W, Khabar KS (2001) ARED: human AU-rich element-containing mRNA database reveals an unexpectedly diverse functional repertoire of encoded proteins, Nucleic. Acids Res. 29:246-254.

Barshop BA, Frieden C (1984) Analysis of interaction of rabbit skeletal muscle adenylate deaminase with myosin subfragments, J. Biol. Chem. 259: 60-66.

Bausch-Jurken MT, Mahnke-Zizelman DK, Morisaki T, Sabina RL (1992) Molecular cloning of AMP deaminase isoform L: sequence and bacterial expression of human AMPD2 cDNA, J. Biol. Chem. 267: 22407-22413.

Bayascas JR, Alessi DR (2005) Regulation of Akt/PKB Ser473 phosphorylation, Mol. Cell. 18: 143-145.

Ben-Levy R, Leighton IA, Doza YN, Attwood P, Morrice N, Marshall CJ, Cohen P (1995) Identification of novel phosphorylation sites required for activation of MAPKAP kinase-2, EMBO J. 14(23): 5920-5930.

Benndorf R, Hayess K, Ryazantsev S, Wieske M, Behlke J and Lutsch G (1994) Phosphorylation and supramolecular organization of murine small heat shock protein HSP25 abolish its actin polymerization-inhibiting activity, J. Biol. Chem. 269:2078020784. 
Brooks SPJ (1992) A simple computer program with statistical tests for the analysis of enzyme kinetics, BioTechniques 13: 906-911.

Brooks SPJ (1994) A program for analyzing enzyme rate data obtained from a microplate reader, BioTechniques 17: 1155-1161.

Buck MJ, Squire TL, Andrews MT (2002) Coordinate expression of the PDK4 gene: a means of regulating fuel selection in a hibernating mammal Physiol. Genom. 8(1): 513.

Butt E, Immler D, Meyer HE, Kotlyarov A, Laass K, Gaestel M (2001) Heat shock protein 27 is a substrate of cGMP-dependent protein kinase in intact human platelets. Phosphorylation induced actin polymerization caused by HSP27 mutants, J. Biol. Chem. 276: 7108-7113.

Cai D, McCarron RM, Yu EZ, Li Y, Hallenbeck JM (2004) Akt phosphorylation and kinase activity are down-regulated during hibernation in the 13-lined ground squirrel, Brain Res. 1014, 14-21.

Carey HV, Andrews MT, Martin SL (2003) Mammalian hibernation: cellular and molecular responses to depressed metabolism and low temperature, Physiol Rev. 83: $1153-1181$.

Carmen GY, Víctor SM (2005) Signalling mechanisms regulating lipolysis, Cell Signal. 18(4):401-8.

Chen Y, Matsushita M, Nairn A C, Damuni Z, Cai D, Frerichs KU, Hallenbeck JM (2001) Mechanisms for increased levels of phosphorylation of elongation factor- 2 during hibernation in ground squirrels, Biochemistry 40: 11565-11570.

Chevalier DC, Allen BG (2000) Two distinct forms of MAPKAP kinase- 2 in adult cardiac ventricular myocytes, Biochemistry 39: 6145-6156.

Chida K, Kasahara K, Tsunenaga M, Kohno Y, Yamada S, Ohmi S, Kuroki T (1990a) Purification and identification of creatine phosphokinase $\mathrm{B}$ as a substrate of protein kinase $\mathrm{C}$ in mouse skin in vivo, Biochem. Biophys. Res. Commun. 173: 351-357.

Chida K, Tsunenaga M, Kasahara K, Kohno Y, Kuroki T (1990b) Regulation of creatine phosphokinase B activity by protein kinase C, Biochem. Biophys. Res. Commun. 173: 346-350.

Cleary EC, Craven SR (1994) Thirteen-lined ground squirrels. In Prevention and Control 
of Wildlife Damage (Hygnstrom SE, Timm RM, Larson GE, eds). Institute of Agriculture and Natural Resources, University of Nebraska, Lincoln.

Cowan KJ and Storey KB (2003) Mitogen-activated protein kinases: new signaling pathways functioning in cellular responses to environmental stress, J. Exp. Biol. 206: 1107-1115

Davies SP, Sim AT, Hardie DG (1990) Location and function of three sites phosphorylated on rat acetyl-CoA carboxylase by the AMP-activated protein kinase, Eur J Biochem. 187(1):183-90.

Dudley GA, Terjung RL (1985) Influence of acidosis on AMP deaminase activity in contracting fast twitch muscle, Am. J. Physiol. 248: C43-C50.

Eddy SF, Storey KB (2003) Differential expression of Akt, PPAR? and PGC-1 during hibernation in bats, Biochem. Cell Biol. 81: 269-274.

Eddy SF, McNally JD and Storey KB (2005). Up-regulation of a thioredoxin peroxidaselike protein, proliferation associated gene, in hibernating bats. Arch. Biochem. Biophys. 435, 101-111.

Eddy SF, and Storey KB (2007) $\mathrm{p} 38^{\mathrm{MAPK}}$ regulation of transcription factor targets in muscle and heart of hibernating bats, Myotis lucifugus. Cell Biochem. Function, in press. E-pub May 9, 2007, DOI: 10.1002/cbf. 1416

English TE, Storey KB (2000) Enzymes of adenylate metabolism and their role in hibernation of the white-tailed prairie dog, Cynomys leucurus, Arch. Biochem. Biophys. 376: 91-100.

Epperson LE, Dahl TA, Martin SL (2004) Quantitative analysis of liver protein expression during hibernation in the golden-mantled ground squirrel, Mol. Cell. Proteomics 3: 920-933.

Epperson LE, Martin SL (2002) Quantitative assessment of ground squirrel mRNA levels in multiple stages of hibernation, Physiol. Genomics 10: 93-102.

Fahlman A, Storey JM, Storey KB (2000) Gene up-regulation in heart during mammalian hibernation, Cryobiology 40(4): 332-342.

Ferns G, Shams S, Shafi S (2006) Heat shock protein 27: its potential role in vascular disease, Int. J. Exp. Path. 87: 253-274.

Frerichs KU, Smith CB, Brenner M, Degracia DJ, Krause GS, Marrone L, Dever TE, 
Hallenbeck JM (1998) Suppression of protein synthesis in brain during hibernation involves inhibition of protein initiation and elongation. Proc. Natl. Acad. Sci. USA 95: 14511-14516.

Frost RA, Lang CH (2007) Protein kinase B/Akt: a nexus of growth factor and cytokine signaling in determining muscle mass, J. Appl. Physiol. 103(1): 378-387.

Galster WA, Morrison PR (1975) Gluconeogenesis in arctic ground squirrels between periods of hibernation, Am. J. Physiol. 228: 325-330.

Geiser F (1988) Reduction of metabolism during hibernation and daily torpor in mammals and birds: temperature effect or physiological inhibition? J. Comp. Physiol. $B$ 158(1): 25-37.

Geiser F (2004) Metabolic rate and body temperature reduction during hibernation and daily torpor, Annu. Rev. Physiol. 66: 239-274.

Gingras AC, Raught B, Sonenberg N (2001) Regulation of translation initiation by FRAP/mTOR, Genes Dev. 15: 807-826.

González C, Ureta T, Sanchez R, Niemeyer H (1964) Multiple molecular forms of ATP:hexose 6-phosphotransferase from rat liver. Biochem. Biophys. Res. Commun. 16: $347-352$.

Greer EL, Brunet A (2005) FOXO transcription factors at the interface between longevity and tumor suppression, Oncogene 24: 7410-7425.

Grigg GC, Beard LA, Augee ML (2004) The evolution of endothermy and its diversity in mammals and birds, Physiol. Biochem. Zool. 77(6): 982-997.

Haddad JJ (2004) Hypoxia and the regulation of mitogen-activated protein kinases: gene transcription and the assessment of potential pharmacologic therapeutic interventions, Int. Immunopharmacol. 4: 1249-1285.

Halse R, Pearson, SL, McCormack JG, Yeaman SJ, Taylor R (2001) Effects of tumor necrosis factor-a on insulin action in cultured human muscle cells, Diabetes 50: 11021109.

Hancock CR, Brault JJ, Terjung RL (2006) Protecting the cellular energy state during contractions: role of AMP deaminase, J. Physiol. Pharmacol. 57: Suppl. 10, 17-29.

Hauner H, Petruschke T, Russ M, Rohrig K, Eckel J (1995) Effects of tumor necrosis factor alpha (TNF alpha) on glucose transport and lipid metabolism of newly- 
differentiated human fat cells in cell culture, Diabetologia 38(7): 764-771.

Heldmaier G, Klingenspor M, Werneyer M, Lampi BJ, Brooks SJ, Storey KB (1999)

Metabolic adjustments during daily torpor in the Djungarian hamster, Am. J. Physiol. 276: E896-E906.

Heller HC, Ruby NF (2004) Sleep and circadian rhythms in mammalian torpor, Annu. Rev. Physiol. 66:275-289.

Hemmer W, Skarli M, Perriard JC, Wallimann T (1993) Effect of okadaic acid on protein phosphorylation patterns of chicken myogenic cells with special reference to creatine kinase, FEBS Lett. 327: 35-40.

Hickey E, Brandon SE, Potter R, Stein G, Stein J, Weber LA (1986a) Sequence and organization of genes encoding the human $27 \mathrm{kDa}$ heat-shock protein, Nucleic Acids Res. 14, 4127-4145.

Hill MM, Clark SF, Tucker DF, Birnbaum MJ, James DE, Macaulay SL (1999) A role for protein kinase B/Akt2 in insulin-stimulated GLUT4 translocation in adipocytes, Mol. Cell. Biol. 19: 7771-7781.

Hisatome I, Morisaki T, Kamma H, Sugama T, Morisaki H, Ohtahara A, Holmes EW (1998) Control of AMP deaminase 1 binding to myosin heavy chain, Am. J. Physiol. 275: C870-C881.

Hittel D, Storey KB (2001) Differential expression of adipose- and heart-type fatty acid binding proteins in hibernating ground squirrels, Biochim. Biophys. Acta 1522(3): 238-243.

Hittel D, Storey KB (2002) The translation state of differentially expressed mRNAs in the hibernating 13-lined ground squirrel (Spermophilus tridecemlineatus), Arch. Biochem. Biophys. 401: 244-254.

Hitti E, Iakovleva T, Brook M, Deppenmeier S,Gruber AD, Radzioch D, Clark AR, Blackshear PJ, Kotlyarov A, Gaestell M (2006) Mitogen-activated protein kinaseactivated protein kinase 2 regulates tumor necrosis factor mRNA stability and translation mainly by altering tristetraprolin expression, stability, and binding to adenine/uridine-rich element, Mol. Cell. Biol. 26:2399-2407.

Hochachka PW, Somero GN (1984) Biochemical Adaptation, Princeton Univ. Press, Princeton, NJ. 
Hoehn KL, Hudachek SF, Summers SA, Florant GL (2004) Seasonal, tissue-specific regulation of Akt/protein kinase $\mathrm{B}$ and glycogen synthase in hibernators, $\mathrm{Am}$. $J$. Physiol. 286: R498-R504.

Holmes BF, Kurth-Kraczek EJ, Winder WW (1999) Chronic activation of 5'-AMPactivated protein kinase increases GLUT-4, hexokinase, and glycogen in muscle, $J$. Appl. Physiol. 87: 1990-1995.

Horman S, Hussain N, Dilworth SM, Storey KB, Rider MH (2005) Evaluation of the role of AMP-activated protein kinase and its downstream targets in mammalian hibernation, Comp. Biochem. Physiol. Part B, 142:374-382

Hornemann T, Stolz M, Wallimann T (2000) Isoenzyme-specific interaction of muscletype creatine kinase with the sarcomeric M-line is mediated by NH2-terminal lysine charge-clamps. J. Cell Biol. 149, 1225-1234.

Hu Z, Wang Y, Graham WV, Su L, Musch MW, Turner JR (2006) MAPKAPK-2 is a critical signaling intermediate in NHE3 activation following Na-glucose cotransport, J. Biol. Chem. 281(34): 24247-24253.

Hauner H, Petruschke T, Russ M, Rohrig K, Eckel J (1995) Effects of tumor necrosis factor alpha (TNF alpha) on glucose transport and lipid metabolism of newlydifferentiated human fat cells in cell culture, Diabetologia 38(7):764-71

Ingwall JS (2002) Is creatine kinase a target for AMP-activated protein kinase in the heart, J Mol. Cell. Cardiol. 34: 1111-1120.

Jakob U, Gaestel M, Engel K, Buchner J (1993) Small heat shock proteins are molecular chaperones, J. Biol. Chem. 268: 1517-1520.

Katzen HM, Schimke RT (1965). Multiple forms of hexokinase in the rat: tissue distribution, age dependency, and properties. Proc. Natl. Acad. Sci. USA 54: 12181225.

Kelly DA, Storey KB (1995) Glycolysis and energetics in organs in hibernating mice Zapus hudsonius, Can. J. Zool. 73: 202-207.

Knight JE, Narus EN, Martin SL, Jacobson A, Barnes BM, Boyer BB (2000) mRNA stability and polysome loss in hibernating Arctic ground squirrels (Spermophilus parryii), Mol Cell Biol. 20: 6374-6379.

Kockeritz L, Doble B, Patel S, Woodgett JR (2006) Glycogen synthase kinase-3 - an 
overview of an over-achieving protein kinase, Curr. Drug Targets 7(11):1377-88.

Kotlyarov A, Gaestel M (2002) Is MK2 (mitogen-activated protein kinase-activated protein kinase 2) the key for understanding post-transcriptional regulation of gene expression? Biochem. Soc. Trans. 30(6): 959-963.

Kotlyarov A., Yannoni Y, Fritz S, Laab K, Telliez JB, Pitman D, Lin LL, Gaestel M (2002) Distinct cellular functions of MK2, Mol. Cell. Biol. 22: 4827-4835.

Kuzhikandathil EV, Molloy GR (1994) Transcription of the brain creatine kinase gene in glial cells is modulated by cyclic AMP-dependent protein kinase, J. Neurosci. Res. 39: $70-82$.

Larade K, Storey KB (2006) Analysis of signal transduction pathways during anoxia exposure in a marine snail: A role for p38 MAP kinase and downstream signaling cascades, Comp. Biochem. Physiol. B 143: 85-91.

Lasa, M, Mahtani KR, Finch, A, Brewer, G, Saklatvala J, Clark AR (2000) Regulation of cyclooxygenase 2 mRNA stability by the mitogen-activated protein kinase p38 signaling cascade, Mol. Cell. Biol. 20:4265-4274.

Lee M, Choi I, Park K (2002) Activation of stress signaling molecules in bat brain during arousal from hibernation, J. Neurochem. 82:867-873.

Lipskaya TY (2001) The physiological role of the creatine kinase system: evolution of views, Biochemistry (Mosc) 66: 115-129.

Loktionova SA, Kabakov AE (2001) Phosphatase inhibitors prevent HSP27 dephosphorylation, destruction of stress fibrils, and morphological changes in endothelial cells during ATP depletion, Bull. Exp. Biol. Med. 132:914-917.

Lowenstein JM (1990) The purine nucleotide cycle revised, Int. J. Sports Med. 11: 537546.

MacDonald JA, Storey KB (1998) cAMP-dependent protein kinase from brown adipose tissue: temperature effects on kinetic properties and enzyme role in hibernating ground squirrels, J. Comp. Physiol. B. 168: 513-525.

MacDonald JA, Storey KB (1999) Regulation of ground squirrel $\mathrm{Na}^{+} \mathrm{K}^{+}$-ATPase activity by reversible phosphorylation during hibernation, Biochem. Biophys. Res. Commun. 254: 424-429.

MacDonald JA, Storey KB (2001) Reassessment of the cold-labile nature of 
phosphofructokinase from a hibernating ground squirrel, Mol. Cell. Biochem. 225(1-): 51-57.

MacDonald JA, Storey KB (2005) Mitogen-activated protein kinases and selected downstream targets display organ-specific responses in the hibernating ground squirrel, Int. J. Biochem. Cell Biol. 37: 679-691.

Mahnke-Zizelman DK, Sabina RL (1992) Cloning of human AMP deaminase isoform E cDNAs: evidence for a third AMPD gene exhibiting alternatively spliced 50 exons, $J$. Biol. Chem. 267: 20866-20877.

Martini D, Ranieri-Raggi M, Sabbatini AR, Raggi A (2001) Regulation of skeletal muscle AMP deaminase: lysine residues are critical for the $\mathrm{pH}$-dependent positive homotropic cooperativity behaviour of the rabbit enzyme, Biochim. Biophys. Acta 1544: 123-132.

McArthur M.D, Hanstock CC, Malan A, Wang LCH, Allen PS (1990) Skeletal muscle $\mathrm{pH}$ dynamics during arousal from hibernation measured by ${ }^{31} \mathrm{P}$ NMR spectroscopy, $J$. Comp. Physiol. B 160: 339-347.

McArthur MD, Milsom WK (1991) Changes in ventilation and respiratory sensitivity associated with hibernation in Columbian (Spermophilus columbianus) and goldenmantled (Spermophilus lateralis) ground squirrels, Physiol. Zool. 64: 940-959.

McLeish MJ, Kenyon GL (2005) Relating structure to mechanism in creatine kinase, Crit. Rev. Biochem. Mol. Biol. 40: 1-20.

Mehlen P, Arrigo AP (1994) The serum-induced phosphorylation of mammalian hsp27 correlates with changes in its intracellular localization and levels of oligomerization, Eur. J. Biochem. 221:327-334.

Meng W, Swenson LL, Fitzgibbon MJ, Hayakawa K, Ter Haar E, Behrens AE, Fulghum JR, Lippke JA (2002) Structure of mitogen-activated protein kinase-activated protein (MAPKAP) kinase 2 suggests a bi functional switch that couples kinase activation with nuclear export, J. Biol. Chem. 277(40): 37401-37405.

Mommsen TP, Hochachka PW (1988) The purine nucleotide cycle as two temporally separated metabolic units: a study on trout muscle, Metabolism 37(6):552-6.

Morin P, Storey KB (2005) Cloning and expression of hypoxia-inducible factor 1a from the hibernating ground squirrel, Spermophilus tridecemlineatus, Biochim. Biophys. 
Acta 1729: 32-40.

Morisaki T, Sabina RL, Holmes EW (1990) Adenylate deaminase: a multigene family in humans and rats, J. Biol. Chem. 265: 11482-11486.

Muise AM, Storey KB (2001) Regulation of hexokinase in a freeze avoiding insect: role in the winter production of glycerol Arch. Insect Biochem. Physiol. 47(1):29-34

Nader GA (2005) Molecular determinants of skeletal muscle mass: getting the "AKT" together, Int. J. Biochem. Cell Biol. 37: 1985-1996.

Neininger A, Kontoyiannis D, Kotlyarov A, Winzen R, Eckert R, Volk HD, Holtmann H, Kollias G, Gaestel M (2002) MK2 targets AU-rich elements and regulates biosynthesis of tumor necrosis factor and interleukin independently at different posttranscriptional levels, J. Biol. Chem. 277: 3065-3068.

Nover L, Scharf KD, Neumann D (1989) Cytoplasmic heat shock granules are formed from precursor particles and are associated with a specific set of mRNAs, Mol. Cell. Biol. 9:1298-1308.

Ogasawara N, Goto H, Yamada Y, Watanabe T, Asano T (1982) AMP deaminase isozymes in human tissues, Biochim. Biophys. Acta 714: 298-306.

Pan DA, Hardie DG (2002) A homologue of AMP-activated protein kinase in Drosophila melanogaster is sensitive to AMP and is activated by ATP depletion, Biochem. J. 367(Pt 1):179-86

Park C, Marqusee S (2005) Pulse proteolysis: a simple method for quantitative determination of protein stability and ligand binding, Nature Methods 2: 207-212.

Pastorino JG, Hoek JB, Shulga N (2005) Activation of glycogen synthase kinase $3 ß$ disrupts the binding of hexokinase II to mitochondria by phosphorylating voltagedependent anion channels and potentiates chemotherapy-induced cytotoxicity, Cancer Res. 65: 10545-10554.

Polakis PG, Wilson JE (1985) An intact hydrophobic N-terminal sequence is critical for binding of rat brain hexokinase to mitochondria, Arch. Biochem. Biophys. 236: 328337.

Ponticos M, Lu QL, Morgan JE, Hardie DG, Partridge TA, Carling D (1998) Dual regulation of the AMP-activated protein kinase provides a novel mechanism for the control of creatine kinase in skeletal muscle. EMBO J. 17: 1688-1699. 
Postnikova GB, Tselikova SV, Kolaeva SG, Solomonov NG (1999) Myoglobin content in skeletal muscles of hibernating ground squirrels rises in autumn and winter, Comp. Biochem. Physiol. A 124(1): 35-37.

Radojkovic J, Ureta T (1987) Hexokinase isoenzymes from the Novikoff hepatoma. Purification, kinetic and structural characterization, with emphasis on hexokinase C. Biochem. J. 242: 895-903.

Ramnanan CJ, Storey KB (2006) Glucose-6-phosphate dehydrogenase regulation during hypometabolism, Biochem. Biophys. Res. Commun. 339(1):7-16.

Ritov VB, Kelley DE (2001) Hexokinase isozyme distribution in human skeletal muscle, Diabetes 50: 1253-1262.

Rose IA, Warms JVB (1967) Mitochondrial hexokinase: release, rebinding, and location, J. Biol. Chem. 242: 1635-1645.

Rourke BC, Cotton CJ, Harlow HJ, Caiozzo VJ (2006) Maintenance of slow type I myosin protein and mRNA expression in overwintering prairie dogs (Cynomys leucurus and ludovicianus) and black bears (Ursus americanus). J. Comp. Physiol. B 176: 709-720.

Rourke BC, Yokoyama Y, Milsom WK, Caiozzo VJ (2004) Myosin isoform expression and MAFbx mRNA levels in hibernating golden-mantled ground squirrels (Spermophilus lateralis), Physiol Biochem Zool. 77: 582-593.

Rundell KW, Tulison PC, Terjung RL (1992) AMP deaminase binding in contracting rat skeletal muscle, Am. J. Physiol. 263: C287-C293.

Rush JWE, Tullson PC, Terjung RL (1998) Molecular and kinetic alterations of muscle AMP deaminase during chronic creatine depletion, Am. J. Physiol. 274: C465-C471.

Sabina RL, Morisaki T, Clarke P, Eddy R, Shows TB, Morton CC, Holmes EW (1990) Characterization of the human and rat myoadenylate deaminase genes, J. Biol. Chem. 265: 9423-9433.

Sarbassov DD, Ali SM, Sengupta S, Sheen JH, Hsu PP, Bagley AF, Markhard AL, Sabatini DM (2006) Prolonged rapamycin treatment inhibits mTORC2 assembly and Akt/PKB, Mol. Cell. 22: 159-168.

Sarbassov DD, Guertin DA, Ali SM, Sabatini DM (2005) Phosphorylation and regulation of Akt/PKB by the rictor-mTOR complex, Science 307: 1098-1101. 
Shah OJ, Anthony JC, Kimball SR, Jefferson LS (2000) 4E-BP1 and S6K1: translational integration sites for nutritional and hormonal information in muscle, Am. J. Physiol. 279, E715-E729.

Shavlakadze T, Grounds M (2006) Of bears, frogs, meat, mice and men: complexity of factors affecting skeletal muscle mass and fat, BioEssays 28: 994-1009.

Shiraki H, Ogawa H, Matsuda Y, Nakagawa H (1979) Interaction of rat muscle AMP deaminase with myosin: II. Modification of the kinetic and regulatory properties of rat muscle AMP deaminase by myosin, Biochim. Biophys. Acta 566: 345-352.

Shults MD, Janes KA, Lauffenburger DA and Imperiali B (2005) A multiplexed homogeneous fluorescence-based assay for protein kinase activity in cell lysates, Nature Methods 2: 277 - 284

Stewart JM, Blakely JA (2000) Long chain fatty acids inhibit and medium chain fatty acids activate mammalian cardiac hexokinase, Biochim. Biophys. Acta. 1484(23):278-86

Stoppani J, Hildebrandt AL, Sakamoto K, Cameron-Smith D, Goodyear LJ, Neufer PD (2002) AMP-activated protein kinase activates transcription of the UCP3 and HKII genes in rat skeletal muscle, Am. J. Physiol. 283: E1239-E1248.

Storey KB (1997) Metabolic regulation in mammalian hibernation: enzyme and protein adaptations, Comp. Biochem. Physiol. A 118: 1115-1124.

Storey KB (2003) Mammalian hibernation: transcriptional and translational controls, Adv. Exp. Biol. Med. 543:21-38.

Storey KB, Storey JM (1990) Facultative metabolic rate depression: molecular regulation and biochemical adaptation in anaerobiosis, hibernation and aestivation, Quart. Rev. Biol. 65: 145-174.

Storey KB, Storey JM (2004) Metabolic rate depression in animals: transcriptional and translational controls, Biol. Rev. Camb. Philos. Soc. 79: 207-233.

Strehler EE, Carlsson E, Eppenberger HM, Thornell LE (1983) Ultrastructural localization of M-band proteins in chicken breast muscle as revealed by combined immunocytochemistry and ultramicrotomy, J. Mol. Biol. 166: 141-158.

Tanabe K, Akamatsu S, Suga H, Takai S, Kato K, Dohi S, Kozawa O (2005) Midazolam suppresses thrombin-induced heat shock protein 27 phosphorylation through 
inhibition of p38 mitogen-activated protein kinase in cardiac myocytes, J. Cell. Biochem. 96: 56-64.

Thatcher BJ, Storey KB (2001) Glutamate dehydrogenase from liver of euthermic and hibernating Richardson's ground squirrels: evidence for two distinct enzyme forms, Biochem. Cell Biol. 79: 11-19.

Tovmasian EK, Hairapetian RL, Bykova EV, Severin SE, Haroutunian AV (1990) Phosphorylation of the skeletal muscle AMP-deaminase by protein kinase C. FEBS Lett. 259: 321-323.

Towler MC, Hardie DG (2007) AMP-activated protein kinase in metabolic control and insulin signalling, Circ. Res. 100(3):328-41

Turner DC, Wallimann T, Eppenberger HM (1973) A protein that binds to the M-line of skeletal muscle is identified as the muscle form of creatine kinase, Proc. Natl. Acad. Sci. USA 70: 702-705.

Van Breukelen F, Sonenberg N, Martin SL (2004) Seasonal and state-dependent changes of eIF4E and 4E-BP1 during mammalian hibernation: implications for the control of translation during torpor, Am. J. Physiol. 287: R349-R353.

Wallimann T, Wyss M, Brdiczka D, Nicolay K, Eppenberger HM (1992) Intracellular compartmentation, structure and function of creatine kinase isoenzymes in tissues with high and fluctuating energy demands: the 'phosphocreatine circuit' for cellular energy homeostasis, Biochem. J. 281: 21-40.

Wang LCH, Lee TF (1996) Torpor and hibernation in mammals: metabolic, physiological, and biochemical adaptations. In: Handbook of Physiology:

Environmental Physiology (Fregley MJ, Blatteis CM, eds.) Oxford University Press, New York, Section 4, Vol. 1, pp. 507-532.

Wang, Q, Somwar R, Bilan PJ, Liu Z, Jin J, Woodgett JR, Klip A(1999) Protein kinase B/Akt participates in GLUT4 translocation by insulin inL6 myoblasts, Mol. Cell. Biol. 19: 4008-4018.

Wheeler TJ, Lowenstein JM (1980) Effects of pyrophosphate, triphosphate, and potassium chloride on adenylate deaminase from rat muscle, Biochemistry 19: 45642567.

Wheeler TJ, Lowenstein JM (1979) Adenylate deaminase from rat muscle. Regulation by 
purine nucleotides and orthophosphate in the presence of $150 \mathrm{mM} \mathrm{KCl} J$. Biol. Chem. 254: 8994-8999.

Whiteman EL, Cho H, Birnbaum MJ (2002) Role of Akt/protein kinase B in metabolism, Trends Endocrinol. Metab. 13(10): 444-451.

Wickler SJ, Hoyt DF, van Breukelen F (1991) Disuse atrophy in the hibernating goldenmantled ground squirrel, Spermophilus lateralis, Am. J. Physiol. 261: R1214-R1217.

Wallimann T, Wyss M, Brdiczka D, Nicolay K, Eppenberger HM (1992) Intracellular compartmentation, structure and function of creatine kinase isoenzymes in tissues with high and fluctuating energy demands: the 'phosphocreatine circuit' for cellular energy ho meostasis, Biochem J. 281: 21-40

Wilson JE (1995) Hexokinases. Rev. Physiol. Biochem. Pharmacol. 126: 65-198.

Wilson JE (1997). An introduction to the isoenzymes of mammalian hexokinase types IIII, Biochem. Soc. Trans. 25: 103-108.

Wilson JE (2003) Isozymes of mammalian hexokinase: structure, subcellular localization and metabolic function J. Exp. Biol. 206: 2049-2057.

Zatzman ML (1984) Renal and cardiovascular effects of hibernation and hypothermia, Cryobiology 21: 593-614.

Zhu X, Smith MA, Perry G, Wang Y, Ross AP, Zhao HW, Lamanna JC, Drew KL (2005) MAPKs are differentially modulated in arctic ground squirrels during hibernation, J. Neurosci. Res. 80(6): 862-868. 